UNIVERSIDADE DE SÃO PAULO

INSTITUTO DE PSICOLOGIA - PSA

Ludymilla Zacarias

Atuação clínica junto a familiares em luto antecipatório em contexto domiciliar: uma proposta a partir do ponto de vista da Psicologia Analítica, com contribuições de Winnicott

São Paulo 


\section{LUDYMILLA ZACARIAS}

Atuação clínica junto a familiares em luto antecipatório em contexto domiciliar: uma proposta a partir do ponto de vista da Psicologia Analítica com contribuições de Winnicott

Versão corrigida

Tese apresentada ao Instituto de Psicologia da Universidade de São Paulo, como parte dos requisitos para obtenção do título de Doutora em Psicologia.

Área de concentração: Psicologia Escolar e do Desenvolvimento Humano

Orientador: Leopoldo Fulgencio 
AUTORIZO A REPRODUÇÃO E DIVULGAÇÃO TOTAL OU PARCIAL DESTE TRABALHO, POR QUALQUER MEIO CONVENCIONAL OU ELETRÔNICO,

PARA FINS DE ESTUDO E PESQUISA, DESDE QUE CITADA A FONTE.

Catalogação na publicação Biblioteca Dante Moreira Leite

Instituto de Psicologia da Universidade de São Paulo

Dados fornecidos pelo(a) autor(a)

Zacarias, Ludymilla

Atuação clínica junto a familiares em luto antecipatório em contexto domiciliar: uma proposta a partir do ponto de vista da Psicologia Analítica com contribuições de Winnicott / Ludymilla Zacarias; orientador Leopoldo Fulgencio. -- São Paulo, 2021. $226 \mathrm{f}$.

Tese (Doutorado - Programa de Pós-Graduação em Psicologia Escolar e do Desenvolvimento Humano) -- Instituto de Psicologia, Universidade de São Paulo, 2021.

1. Psicologia Clínica. 2. Jung. 3. Winnicott. 4. Luto antecipatório. 5. Atendimento domiciliar. I. Fulgencio, Leopoldo, orient. II. Título. 


\section{FOLHA DE APROVAÇÃO}

Nome: Ludymilla Zacarias

Título: Atuação clínica junto a familiares em luto antecipatório em contexto domiciliar: uma proposta a partir do ponto de vista da Psicologia Analítica com contribuições de Winnicott

Tese apresentada ao Instituto de Psicologia da Universidade de São Paulo para obtenção do título de Doutora em Psicologia

Aprovado em:

Banca Examinadora:

Prof. Dr. LEOPOLDO FULGENCIO - USP

Julgamento: Assinatura:

Prof. Dra. MARIA JULIA KOVÁCS - USP

Julgamento: Assinatura:

Prof. Dr. RODRIGO SANCHES PERES - UFU

Julgamento: Assinatura:

Prof. Dra. PATRICIA ELIZABETH WIDMER COSTA - USTJ

Julgamento: Assinatura:

Prof. Dra. MARIA HELENA FRANCO - PUC

Julgamento: Assinatura:

Prof. Dr. CARLOS AUGUSTO SERBENA - UFPR

Julgamento: Assinatura: 


\section{DEDICATÓRIA}

Dedico esta tese aos meus filhos Raul e Francisco, ao meu marido-amigo Kaio. Costuramos nossas (e novas) histórias, com coloridos, remendos, trabalho, admiração e brincadeiras... ao pé do fogão à lenha imaginário, curamos e encontramos novos sentidos... Amar e continuar amando livremente: minha ontologia! Dedico esta tese também à minha mãe e ao meu pai: esta conquista é nossa! 


\section{AGRADECIMENTOS}

Tem tanta gente que preciso agradecer... foram cinco anos ao todo e, no final, uma tese, dois filhos (um deles parido no meio do doutorado, exatamente nove dias depois da qualificação), uma metanoia em andamento, a vivência de uma pandemia e um amadurecimento absurdo... Neste tempo aprendi a brincar de carrinho, a ser mãe de dois, aprendi a esperar, aprendi a diferença entre ser doce e mansa (em um mundo estruturalmente machista), aprendi a "mostrar os dentes" e deixar a minha Baba Yaga colocar seus pontos de vista, conectei com minha ancestralidade, minha "mulher selvagem" - como diria Clarissa Pinkolas Estés, aprendi a confiar na vida e entendi a importância das nossas tribos inventadas, aprendi muito tecnicamente, quebrei a cara, consertei várias vezes, chorei, gargalhei, vi o mar, fiquei de mau humor com a água gelada da cachoeira, inventei histórias, lutei, trabalhei incessantemente (muitos pratos para equilibrar), enterrei parte de mim e nasci mais e mais muitas outras vezes...forte, leve, robusta, com ossos e carnes benditos!

São tantas pessoas que deveriam ser homenageadas aqui... Mas, infelizmente, terei que registrar apenas parte delas. A todas e todos o meu imenso obrigada!

Ao Kaio, que sempre lutou ao meu lado nessa jornada democrática, amorosa, profunda e cheia de significados. Aos meus filhotes lindos, bagunceiros e amorosos (bico doce e beijoqueiro) Raul e Francisco, obrigada por me ensinar tanto e pela oportunidade de amar desse modo tão profundo...

À minha família, que se enche de orgulho da caçula aqui (risos), e à família do Kaio, que também foi muito importante durante todo o processo. Gostaria de agradecer em especial ao meu pai, Sandoval, professor universitário de matemática, à minha mãe Clara Emília, artista plástica...obrigada por me ensinarem, entre raciocínios lógicos e esculturas, que humildade e lutar por uma vida honesta são o melhor caminho. Eu nunca sonhei em seguir a carreira acadêmica. Para mim eu seria uma psicóloga que, no máximo, partiria para a licenciatura também, mas uma tendência familiar dedicada aos estudos me arrastou para a academia, para a pesquisa. Pai, para mim, esse doutorado é a finalização do seu MESTRADO INTERROMPIDO (por motivo de força maior) NA USP! Esse título de DOUTOR(a) é seu também! Obrigada, mãe, pelo incentivo e por sempre me encher de amor na consolidação de quem eu sou enquanto pesquisadora-escritora-psicóloga!! 
Ao Leopoldo, por acolher uma pesquisadora forasteira, por permitir que eu voasse acompanhada por Jung e Winnicott (o melhor dos sonhos) e descobrisse o poder de SER em autonomia.

À Maria Júlia Kovács, minha diva! Muito obrigada por ser essa educadora que me inspira, com sua abundância de conhecimento e humildade. Sua postura ética, generosidade e conhecimento me iluminam. Obrigada por permitir que eu partilhasse um pedaço dessa história com você!

À Marisa Catta-Preta, por estar sempre comigo, me supervisionando, me ensinando e me acolhendo nas angústias durante meu percurso acadêmico e técnico, principalmente no começo. Tenho a honra de dividir essa tese com você, minha querida! Obrigada por fazer eu acreditar que a vida tem seu tempo e que a "a vida espera...". Obrigada por sempre estar ao meu lado. Sem você seria muito difícil caminhar em terras áridas...

À Laura Villares de Freitas, que me acolheu nos meus primeiros passos no doutorado e me contagiou com o olhar junguiano para os grupos. Obrigada por me ajudar a ver o inimaginável!

À Patrícia Widmer, por uma infinidade de motivos: pela ajuda acadêmica que me organizou o pensamento (aquele guarda-chuva seguro que só uma irmã pode oferecer no meio da tempestade), e pela deliciosa conquista de sua amizade!!! Sua companhia me descomplica, me dá colo diante das minhas humanidades... sem sua ajuda seria muito difícil...

Aos amigos uspianos, que se tornaram amigos de verdade, amigos que quebraram o protocolo, as fronteiras, que puderam conviver de outros modos, não só no "modo pesquisadores". Nunca esquecerei dos almoços cheios de risadas e conversas sem reservas, profundas, engraçadas, engajadas, brincantes! Obrigada por tudo, pelo colo, pela a oportunidade de dar colo, pelas brincadeiras com os filhos, pelos encontros online (na pandemia), pelas lives profissionais que fizemos juntos (as), pela ajuda técnica (e tecnológica) e pelas horas e horas conversadas sobre a vida, sobre as dores, sobre achar saídas... Obrigada Marília Velano, Fernanda Fernandes, Mariana Pajaro, Estehr Hwang, Thiago Marques, Tiago Alves, Georgiano Santos, Marcia Bozon, Fernanda Dias, Aline Piña, Elizabeth Rabelo, Laura Antunes. Obrigada especial ao Thiago Marques, que passou valiosas horas de sua vida ajudando a amiga aqui com sua luta incessante com a tecnologia! 
À minha querida Sandra Bezerra, por estar comigo com toda a profundidade que eu precisava... dando o suporte e sendo meu holding suficientemente bom!

Às minhas "minas" prediletas, a minha tribo inventada, minha tenda vermelha... Obrigada à Magui, Michele, Claudinha, Nina, Karina, Renata, Juliana, Lia (in memoriam) ... Muito obrigada por todo o carinho e por serem mulheres poderosamente livres e amorosas em sua sororidade... Vocês, durante todos esses anos, foram meu chão, meu alimento. Hoje sou uma mulher mais inteira porque foi possível dividir a vida com vocês. A nossa querida Lia um dia falou mais ou menos assim: "meu sonho é que essas mulheres transbordem, sejam seus sonhos, sejam poder, sejam ventania, sejam colo quente uma para a outra, meu sonho é ver essas mulheres explodindo!’. Sim, as mulheres maravilhas existem e eu ando com elas.

Aos “irmãos de alma” que há décadas estão comigo, a família que eu escolhi e que é meu clã sagrado, onde eu posso ser eu, sem reservas, sem censura. Obrigada por tudo, Alê, Paty, Palmira, Anderson, Paola e Juninho. Amo muito vocês!!

Agradeço ainda ao Grupo de Apoio a pais e mães enlutados Lado a Lado e às amigas de luta e de cuidado ao luto: Juliana Mathias e Patrícia Galvão. Obrigada por sempre estarem comigo e entenderem meu tempo...

Obrigada ao antigo Programa de Atendimento Domiciliar (PAD-UFU) e aos meus pacientes que me confiaram suas histórias...

Obrigada a CAPES pela bolsa de pesquisa e, principalmente, por ter sido resistência em tempos obscuros.

Obrigada a Olívia (secretaria do PSA) e ao Gustavo (secretaria da pós-graduação), que sempre me ajudaram nas burocracias desse longo processo. 


\section{RESUMO}

Zacarias, L. (2021). Atuação clínica junto a familiares em luto antecipatório em contexto domiciliar: uma proposta a partir do ponto de vista da Psicologia Analítica com contribuições de Winnicott (Tese de Doutorado). Instituto de Psicologia, Universidade de São Paulo, São Paulo.

O adoecimento de um indivíduo por doença crônico-degenerativa leva os familiares e seu entorno ao contato com uma morte anunciada e, portanto, à vivência do luto antecipatório. Em casos graves, os pacientes podem ser assistidos por equipes multiprofissionais no próprio domicílio. Psicólogas e psicólogos têm como foco de atendimento tanto o paciente quanto os familiares. Entretanto, observa-se ainda uma carência de estudos no que diz respeito à compreensão do fenômeno do luto antecipatório de familiares neste contexto e a falta de ferramentas técnicas para o manejo adequado. $\mathrm{O}$ objetivo geral da presente pesquisa foi desenvolver, primeiro, uma compreensão sobre a experiência do luto antecipatório desses familiares, a partir do arcabouço teórico de Jung e sucessores, acrescido de contribuições do psicanalista Winnicott; segundo, a partir dessa elaboração, formular orientações técnicas que possam contribuir para a atuação psicológica com esses familiares. O método utilizado foi um estudo estrutural-conceitual dos constructos da Psicologia Analítica e a busca de conceitos pertinentes desenvolvidos por Winnicott. Como resultado, temos que, a partir de Jung, o processo de luto é vivenciado, na saúde, de modo oscilatório entre o ponto de vista do ego com inúmeras ambivalências e, também, pelo ponto de vista do self, permitindo ao enlutado os sentimentos de paz, alegria e confiança. O processo de luto é uma dinâmica de adaptação na qual podem ocorrer regressões e progressões da energia psíquica e vários processos como tensão, polarização, integração e transformação. Jung recomenda que o ser humano deve acessar a morte também em seu aspecto simbólico e que as imagens advindas do inconsciente sejam utilizadas para ampliar os recursos no enfrentamento. O processo de luto antecipatório pode, portanto, carregar um poder de transformação, regeneração e de encontro com o outro e com o si mesmo no processo de individuação. De Winnicott, respeitadas as diferenças paradigmáticas, acrescentou-se que o desenvolvimento humano, a capacidade de ter "fé em...", a experiência com angústias impensáveis e a experiência da primeira morte podem ter uma contribuição significativa na lida com a segunda morte. Outro resultado da pesquisa foi a construção de considerações técnicas para a atuação junto ao grupo familiar. São indicadas orientações sobre as peculiaridades do trabalho em setting domiciliar, importância do holding suficientemente bom com o grupo, a postura da/do terapeuta, da atenção aos processos individuais e do coletivo familiar, a utilização da escuta simbólica e do uso de técnicas expressivas que auxiliem no enfrentamento do luto. Isso posto, o manejo deverá oportunizar o processo de individuação e desinterdição da comunicação intrafamiliar, construindo a vivência do luto antecipatório enquanto um rito de passagem. Este conjunto de análises e desenvolvimentos contribui para cobrir lacunas no que tange ao conhecimento clínico e teórico produzido pela Psicologia. Contudo, há necessidade de mais estudos para complementar este campo de atuação.

Palavras-chave: Psicologia Clínica. Jung. Winnicott. Luto antecipatório. Atendimento domiciliar. 


\begin{abstract}
Zacarias, L. (2021). Clinical practice with family members in anticipatory grief in the home context: a proposal from the point of view of Analytical Psychology with contributions from Winnicott (Doctoral Thesis). Institute of Psychology, University of São Paulo, São Paulo.
\end{abstract}

The illness of an individual due to chronic-degenerative disease takes family members and their surroundings into contact with an announced death, experiencing anticipatory grief at some level. In severe cases, patients can be assisted by multiprofessional teams at home. Psychologists focus on both the patient and family members. However, there is still a lack of studies regarding the understanding of the anticipatory grief phenomenon of family members in this context and a lack of technical tools for proper management. The general objective of this research was to develop, first, an understanding on anticipatory grief experience of these family members, based on the theoretical framework of Jung and successors added to some contributions by the psychoanalyst Winnicott; second, from this elaboration, formulate technical guidelines that would contribute to the psychological practice with these family members. The method used was a structural-conceptual study of the constructs of Analytical Psychology and the search for relevant concepts developed by Winnicott. As a result, we have that, from the Jung, the grieving process is experienced, in health, in an oscillatory way between the point of view of the ego, with several ambivalences and, also, from the point of view of the self, allowing the feelings of peace, joy and confidence in bereaved ones. The grieving process is an adaptation dynamic in which psychic energy regressions and progressions can occur, and various processes such as tension, polarization, integration, transformation. Jung recommends that human beings should also access death in its symbolic aspect, and that images from the unconscious, be used to expand resources for such coping. The anticipatory grief process can, therefore, bring a power of transformation, regeneration and encounter with the other and oneself in the individuation process. From Winnicott, respecting the paradigmatic differences, it was added that the human development, the ability to have "faith in ...", the experience with unthinkable anxieties and the experience of the first death can have a significant contribution in dealing with the second death. Another result of the research was the construction of technical considerations for the clinical practice with the family group. Here, guidance is given on the peculiarities of work in the home setting, the importance of a good-enough holding within the group, the position of the therapist, attention to individual processes and collective family, the use of symbolic listening and the use of expressive techniques that help in coping with grief. This said, the management should provide an opportunity for the process of individuation and disinhibition of intrafamily communication, building the experience of anticipatory grief as a rite of passage. This set of analyzes and developments contributes to fill gaps regarding the clinical and theoretical knowledge that until then have been produced by Psychology. However, further studies are needed to complement this playing field.

Keywords: Clinical Psychology. Jung. Winnicott. Anticipatory grief. Home care. 


\section{SUMÁRIO}

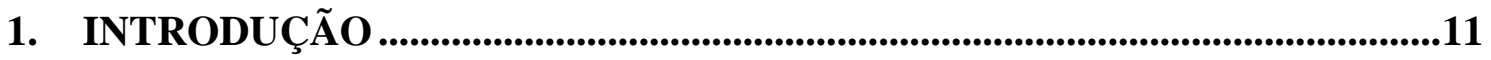

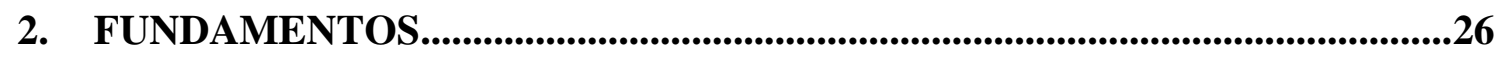

2.1. Luto Antecipatório: definição, descrição e estado atual do conhecimento ............... 26

2.1.1. Luto antecipatório de familiares em contexto de cuidados domiciliares: uma

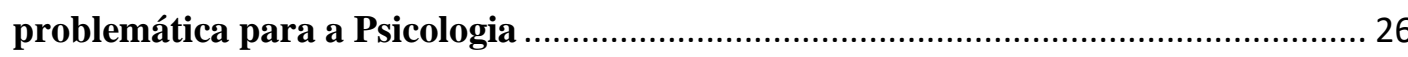

2.1.1.1. Bases teóricas: contribuições para a compreensão do processo de luto, um

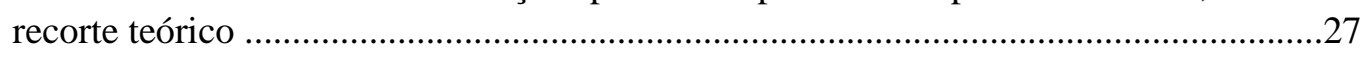

2.1.1.2. Apresentação dos aspectos gerais do luto, contexto e processos ........................30

2.1.1.3. A noção de luto antecipatório ……………………...........................................38

2.1.1.4. Reflexões sobre a "morte domada", "morte interdita" e "morte anunciada" e o novo contexto de doenças crônico-degenerativas ........................................................43

2.1.1.5. Atendimento em domicílio: histórico, portaria, implicações do trabalho em equipe e peculiaridades do trabalho psicológico neste contexto

2.1.2. Manejo psicológico em contexto do luto antecipatório: a quem se destina o cuidado?

2.2. A compreensão do luto e do luto antecipatório do ponto de vista da Psicologia Analítica 60

2.2.1. Quadro geral da teoria analítica para compreensão do luto. 60

2.2.1.1. Aspectos gerais da Psicologia Analítica...........................................................61

2.2.1.2. O modelo de ser humano (ontologia) para Jung... . .77

2.2.1.3. A teoria do desenvolvimento humano do ponto de vista de Jung e processo de

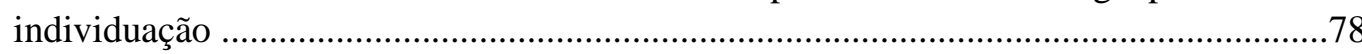

2.2.2. Contribuições de Jung para a compreensão do enlutamento.............................. 93

2.2.2.1. Aspectos do luto de si e da perda do outro afetivamente vinculado/outro

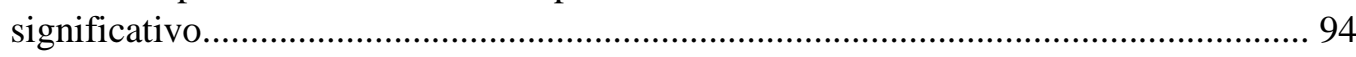

2.2.2.2. Perspectiva simbólica: morte, sonho e mitos...................................................110

2.3. Contribuições de Winnicott para compreensão do luto antecipatório .....................118

2.3.1. Quadro geral da teoria psicanalítica do desenvolvimento emocional do ponto de

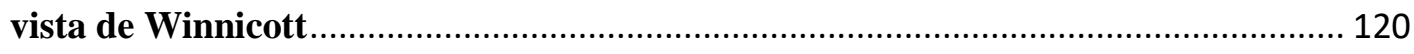

2.3.1.1. O modelo ontológico do ser humano para Winnicott........................................123

2.3.1.2. A teoria do desenvolvimento socioemocional do ponto de vista de Winnicott125

2.3.2. Contribuições de Winnicott para compreensão do enlutamento ....................... 134

2.3.2.1. Modos de ser/estar e relacionar-se nas diversas fases do desenvolvimento

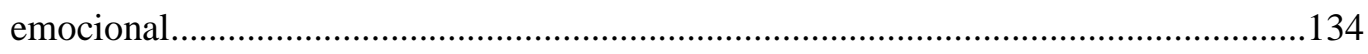

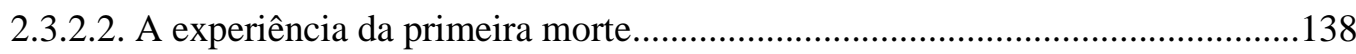


2.3.2.3. A construção da capacidade de ter "fé em..." e a noção da continuidade do ser versus quebra nessa continuidade: as angústias impensáveis e impactos no processo de

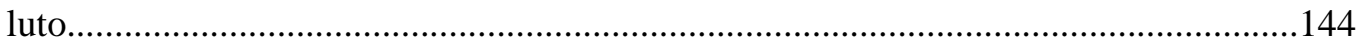

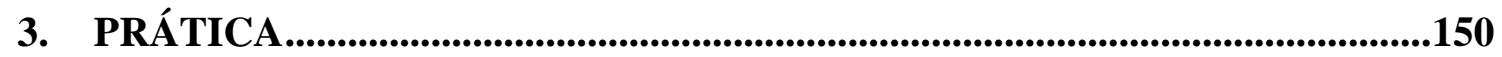

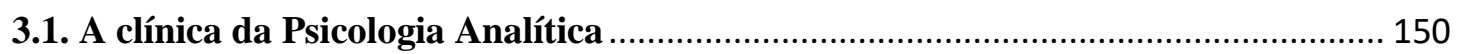

3.1.1 Processo terapêutico individual e o manejo de pacientes em luto...................... 150

3.1.2 Manejo da terapia individual junto a pacientes em luto..................................... 163

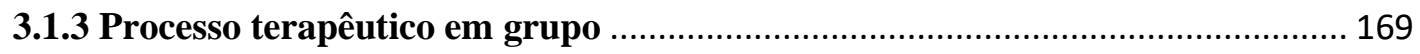

3.2. A clínica da Psicanálise do ponto de vista de Winnicott ........................................... 183

3.3. Considerações sobre a atuação clínica junto a familiares em luto antecipatório em contexto domiciliar a partir do quadro da Psicologia Analítica com contribuições de

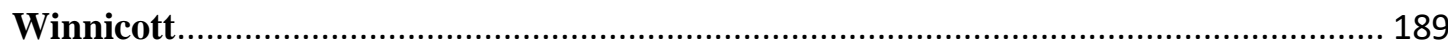

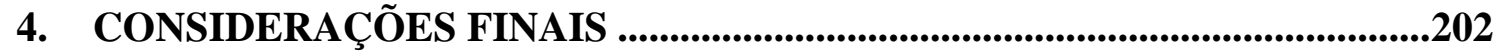

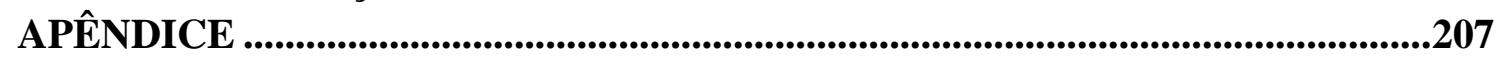

APÊNDICE A - Produto destinado aos usuários da saúde ......................................... 208

APÊNDICE B - Produto técnico destinado aos psicólogos e psicólogas que trabalham na modalidade psicologia domiciliar ............................................................................ 210

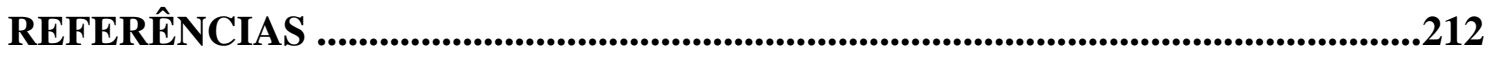




\section{INTRODUÇÃO}

Quando alguém recebe a notícia de que sofre de uma doença grave, incurável, que, ao que tudo indica, será a causa da sua morte, um processo de luto tem início, um luto pelo fim de si mesmo, mas também um luto pelas perdas que a própria doença provoca, pela saúde perdida, pelas mudanças da vida familiar em casa, no trabalho, lazer, luto pelo impacto na vida sexual, da própria identidade como pessoa saudável. Porém, o luto não é exclusivo do indivíduo que se percebe finito por uma doença, pois também passa a ser vivenciado pelos familiares e seu entorno afetivo. Este luto, anterior ao óbito propriamente dito, foi identificado por Lindemann em 1944 e recebeu o nome de luto antecipatório (Lindemann, 1944).

O luto é um processo que faz parte da existência humana e tem sido abordado pelas mais diversas áreas de conhecimento sendo que a sua compreensão enquanto um objeto da Psicologia é relativamente novo, mesmo porque a própria constituição da Psicologia como ciência é recente. Não se trata, nessa tese, de fazer um estudo sobre o luto na história da Psicologia, mas sim, partindo da tentativa de caracterizá-lo enquanto um fenômeno, estabelecer um quadro teórico-epistemológico, que nos auxiliará no entendimento e na reflexão de um conjunto de problemas específicos na prática clínica.

Quando uma morte é anunciada, todo o entorno é impactado. Importante ressaltar que o luto pode ser olhado por um viés generalista, contudo, são várias as formas de observá-lo. Por exemplo, a experiência vivida a partir da pessoa que irá morrer, do familiar que poderá se constituir como cuidador principal durante o processo de adoecimento do ente querido e também o luto dos outros membros da família extensa, amigos e entorno social. Talvez seja impossível chegar a uma definição única do fenômeno, bem como seu manejo, dado que este tem um caráter multifacetado, podendo ser abordado por diversos saberes (Franco, 2002), diversas perspectivas teóricas, formulando problemas e soluções díspares de acordo com cada perspectiva. Como percebeu Popper (1957) e, na mesma direção, Kuhn (1970), não há observação nem 
apresentação de um fenômeno, de um problema, que não esteja condicionado pelo quadro paradigmático a partir do qual este é apreendido.

A pesquisa que aqui se apresenta é desenvolvida como tese de doutorado e é norteada pelo desejo de contribuir para o desenvolvimento de mais ferramentas para a atuação clínica no contexto do luto antecipatório. O objetivo geral é desenvolver, primeiro, uma compreensão sobre a experiência do luto antecipatório de familiares de pessoas diagnosticadas com doenças graves e em cuidados domiciliares, a partir do arcabouço teórico de Carl Gustav Jung e sucessores, acrescido de algumas contribuições do psicanalista Donald Woods Winnicott; e, segundo, a partir deste tipo de elaboração, formular orientações técnicas que possam contribuir para a atuação de psicólogas e psicólogos que atuem com famílias em setting domiciliar.

Com a finalidade de assimilar qual é o fenômeno sobre o qual versa essa pesquisa, tanto em termos descritivos como em termos que envolvem contextos socioculturais, vou retomar alguns estudos e caracterizações que tratam o luto antecipatório como um fenômeno específico, bem como as práticas psicoterápicas que têm sido a ele associadas, para, depois, estabelecer, com mais precisão, de que ponto de vista vou abordar esse problema.

O psiquiatra Erich Lindemann (1944), a partir de sua pesquisa, observou que as mulheres de soldados que eram enviados para batalha desenvolviam reações de enlutamento desde o momento em que seus maridos partiam, tocadas pela possibilidade de que eles morressem em suas missões.

De acordo com Fonseca e Fonseca (2002), o que foi observado por Lindemann é compreendido como sendo um processo adaptativo, composto por várias reações tais como momentos depressivos, de raiva, com movimentos de desorganização e reorganização psicológicos, cognitivos e de interação social. Para o autor, esse fenômeno teria a função de proteger e preparar as esposas para a notícia da morte que poderiam receber a qualquer momento. A perspectiva de Lindemann é voltada para a possibilidade da morte dos soldados, desenvolvido como um mecanismo de defesa frente à ameaça de morte que espreita suas esposas.

Contudo, o termo luto antecipatório sofreu uma ampliação extrapolando sua primeira concepção. O termo passou a ser utilizado e compreendido como o luto que ocorre no processo de adoecimento. Este luto tem marcas, aspectos e características próprias. Na década de 80, houve uma grande produção de estudos sobre o luto antecipatório, tendo como uma das precursoras a pesquisadora Therese A. Rando, com a 
publicação de Loss and anticipatory grief em (1986). Vários estudos foram realizados com pessoas e familiares que recebiam a notícia de uma morte anunciada, como pessoas que eram diagnosticadas com doenças graves e/ou terminais (Fonseca \& Fonseca, 2002; Lebow, 1976; Pine, 1986; Rando, 1986; Worden, 1998).

Rando, Pine, Worden, Lebow, dentre outros estudiosos do luto antecipatório, marcaram o aprofundamento das reflexões sobre este tema. Na compreensão de Rando (1986), o luto que antecede a morte em si tem muitas facetas, pois envolve o enlutamento do próprio paciente, dos familiares e do meio social. Este luto é deflagrado a partir do diagnóstico e perdura até a morte propriamente dita. De acordo com Pine (1986), o processo de luto antecipatório pode ser considerado parte de um luto global, e na mesma direção Worden (1998) pondera que várias funções do luto pós-óbito são vivenciadas durante o luto pré-morte. Apesar de não existir concordância total no que diz respeito às questões que cercam o luto antecipatório, os pesquisadores entendem que este tipo de luto é legítimo e deve ser foco de atenção da equipe de saúde.

Podemos perceber que tal situação cerca pacientes e familiares de sofrimento, o que é agravado devido à rotina de tratamento. No caso de doenças crônico-degenerativas, é instalada uma variável imensamente relevante para o desenvolvimento do luto antecipado, já que este tipo de adoecimento traz comprometimentos para a autonomia do paciente e tem duração prolongada.

Diversas têm sido as propostas de cuidado para tais situações. Como podemos citar o trabalho das pioneiras Cicely Saunders (1990), Elizabeth Kübler-Ross (1996, 1998a, 1998b) e a produção de correntes teóricas e técnicas como, por exemplo, os Cuidados Paliativos (Caponero \& Bifulco, 2018; Caponero \& V.A., 2016; Paliativos, 2009) que propõem protocolos de cuidados e de manejos destas situações focados em "pacientes fora de possibilidades de cura" (Saunders, 1990).

Cicely Saunders, por exemplo, na década de 1960, desenvolveu o modelo de atuação denominado Hospice, que tem a preocupação de garantir a dignidade de vida, o direito à boa morte, a atenuação do sofrimento global e o cuidado tanto com o paciente quanto com os familiares e entorno (Paliativos, 2009; Saunders, 1990). Este programa de cuidados paliativos inspirou o serviço de saúde que recebeu o nome de "Atenção Domiciliar" - ou "Home Care". Serviço que foi redefinido recentemente, no Brasil, pela Portaria $N^{\circ} 825$, de 25 de abril de 2016 no âmbito do Sistema Único de Saúde pelo Ministério da Saúde (2016). Este serviço foi definido da seguinte maneira:

Art. $2^{\circ}$ Para efeitos desta Portaria considera-se: 
I - Atenção Domiciliar (AD): modalidade de atenção à saúde integrada às Rede de Atenção à Saúde (RAS), caracterizada por um conjunto de ações de prevenção e tratamento de doenças, reabilitação, paliação e promoção à saúde, prestadas em domicílio, garantindo continuidade de cuidados;

II - Serviço de Atenção Domiciliar (SAD): serviço complementar aos cuidados realizados na atenção básica e em serviços de urgência, substitutivo ou complementar à internação hospitalar, responsável pelo gerenciamento e operacionalização das Equipes Multiprofissionais de Atenção Domiciliar (EMAD) e Equipes Multiprofissionais de Apoio (EMAP).

Tal portaria padroniza, dentro da esfera pública, os objetivos, o funcionamento, os recursos humanos e financiamentos para sua execução. Afinada às normas e diretrizes das políticas previamente garantidas pelo Sistema Único de Saúde, este documento esclarece o que é considerado atenção domiciliar e seu espectro de atuação na rede de atenção à saúde. É importante deixar claro que esta é a estrutura orientada na iniciativa pública a partir de 2016. Antes desta portaria, os serviços seguiam modelos próprios. Na iniciativa privada, a forma de atuação é diferente, não seguindo tais padronizações.

No desenvolvimento da primeira parte do item 2, denominado "Fundamentos", descreverei com mais detalhes o funcionamento deste tipo de serviço, mas neste momento é necessário descrever, mesmo que brevemente, como este serviço funciona para que o contexto comece a ser desenhado. O atendimento tipo "atenção domiciliar" (home care) é dedicado a pacientes que desenvolveram doenças que tornaram extremamente inviável a sua locomoção. Tais pacientes precisam continuar seus respectivos tratamentos e, por não conseguirem ser transportados até a unidade de saúde, são admitidos nos serviços de atendimento domiciliar, nos quais a equipe é que se desloca para oferecer os devidos cuidados.

Este tema é de extrema importância para refletir sobre a prevenção e a promoção de saúde global dos sujeitos e comunidades, relevante para o desenvolvimento de mais recursos no que tange a saúde coletiva e individual do público-alvo, visto que a transição demográfica ocorrida nas últimas décadas, graças aos avanços científicos, econômicos e industriais, tem levado a uma evolução progressiva de altas taxas de mortalidade por doenças crônico-degenerativas. Este cenário mostra-se irreversível, levando-se em conta que os idosos representarão em 15\% da população brasileira, em 2025 (Barreto \& Carmo, 1995; Gonzaga, 2012).

A longevidade estendida é realidade cada vez mais presente no Brasil, assim, a multiplicidade de conceitos sobre envelhecimento tenta incluir os sentidos atribuídos à passagem do tempo versus a realidade biológica objetivada nas transições físicas. $\mathrm{O}$ envelhecimento humano é um processo gradativo que engloba aprendizagem, desenvolvimento e amadurecimento, no entanto o avanço progressivo do tempo pode culminar em diversas perdas físicas, sociais, cognitivas e exige intensa elaboração 
emocional do sujeito que envelhece visando uma adaptação saudável às mudanças desta fase que avança. A sociedade ocidental não oferece um lugar de destaque aos seus idosos e estes precisam enfrentar mais perdas do envelhecimento do que ganhos da maturidade (Bromberg, 2000). Neste contexto, seus lutos podem decorrer de perdas nos âmbitos social, financeiro, fisiológico e simbólico .... Mesmo que o envelhecimento dependa de fatores como a percepção que o indivíduo e a sociedade detêm sobre o processo, é certo de que, em muitos casos, com o avanço do tempo, o corpo e a saúde sofrem o impacto das degenerações e envelhece, podendo apresentar maiores suscetibilidades ou vulnerabilidades e tornar-se cada vez mais propenso ao desenvolvimento de doenças e moléstias graves ou crônicas. Essa perda fisiológica do envelhecimento implica luto intenso, pois o corpo doente rompe a ilusão de imortalidade. (Kreuz \& Franco, 2017, pp. 169-170)

Diversas pesquisas demonstram que perdas por morte são capazes de provocar um impacto acentuado na família, o qual pode se fazer sentir nos âmbitos físico, psicológico e social (Bromberg, 1997; Parkes, 1998; Couto, 2004; Gonzaga, 2012). Nesse contexto, temos o agravante de que as doenças crônico-degenerativas perduram, em média, por um período que varia de quinze a vinte anos (Melo \& Saintrain, 2009). Sendo assim, o adoecimento prolongado pode desenvolver nos familiares, além de um desgaste crônico, a falsa esperança que a morte não ocorrerá. Esta ideia ilusória causada pelo prolongamento da morte pode fazer com que os familiares não entrem em contato com a perda.

Ser afetiva e cognitivamente impermeável neste processo, negando ou mantendo distanciamento da realidade em que se encontra o ente adoecido, pode ocasionar aos familiares dificuldades no pós-óbito, gerando sequelas conhecidas como a vivência de luto complicado, inibido e/ou negligenciado (Gonzaga, 2012; Parkes, 1998). Este ponto será mais bem trabalhado no decorrer da pesquisa, bem como um outro risco já identificado pelos pesquisadores que está relacionado ao adoecimento dos familiares, na medida em que estes, ao negligenciarem os próprios limites durante o cuidado prolongado, podem gerar problemas à sua saúde. Couto (2004) utilizou o termo "paciente oculto" para denominar estes cuidadores sem orientação ou resguardo da rede de apoio, deixando em evidência a vulnerabilidade deles frente ao cuidado prolongado, e a necessidade de receber atenção externa para sustentá-los nessa nova realidade do adoecimento, tanto quanto ter na família uma parceria durante o tratamento como aponta Matsumoto (2012). Para o autor, é imprescindível oferecer um sistema de suporte para que a família possa enfrentar o processo de luto:

Nunca estamos completamente sós. O ser humano é por natureza um ser gregário. Todo o núcleo familiar e social do paciente também "adoece". Segundo Dra. Maria Helena Pereira Franco (11), 'a unidade de cuidados paciente-família se coloca como una e específica ao mesmo tempo. A célula de identidade do ser humano é a família, respeitadas todas as condições que fazem dela um universo cultural próprio, muitas vezes 
distante ou até mesmo alheio ao universo cultural dos profissionais da saúde'. A família, tanto a biológica como a adquirida (amigos, parceiros etc.), pode e deve ser nossa parceira e colaboradora. Essas pessoas conhecem melhor do que nós o paciente, suas necessidades, suas peculiaridades, seus desejos e angústias, muitas vezes não verbalizados pelo próprio paciente. Da mesma forma, essas pessoas também sofrem e seu sofrimento deve ser acolhido e paliado. (Matsumoto, 2012, p. 28)

De acordo com Franco (2018), a doença progressiva delineia uma mudança perante a vida de todos os envolvidos. Os familiares são impactados desde o diagnóstico, em seus projetos e forma de se relacionar entre si e com o mundo. Cada unidade familiar tem regras (implícitas e explicitas) e formas próprias de lidar com suas emoções e crises. Segundo a autora, é decisiva, em situação de luto antecipatório, a maneira como a família lida com situações de crise. Essas peculiaridades devem ser levadas em consideração no manejo profissional.

Conforme a morte se aproxima, tanto família quanto paciente devem ser amparados e orientados. Não ter respaldo pode afetar o luto pós-óbito, sendo este um fator de risco para o desenvolvimento de um luto complicado.

Fonseca \& Fonseca (2002), se dedicaram a pesquisa sobre o luto antecipatório e manejos neste contexto. Para eles, é necessário que as famílias entrem em processo de luto:

O luto antecipatório provê, aos membros da família, de tempo para gradualmente absorver a realidade de uma perda iminente. Desta forma, torna-se possível a cada indivíduo finalizar situações incompletas com a pessoa que está por morrer, no nível objetivo e concreto, como por exemplo, a resolução de situações do dia a dia, situações econômicas, planos de ação... quer no nível subjetivo e pessoal, como, por exemplo, dizer adeus, falar sobre seu amor, falar sobre assuntos que gostaria de ter abordado anteriormente, mas, faltou oportunidade, perdoar ou pedir perdão, dentre outras. (Fonseca \& Fonseca, 2002, pp. 83-84)

Fonseca (2004), em seu livro dedicado exclusivamente ao luto antecipatório e no qual trata com profundidade dos aspectos teóricos e de intervenção psicológica frente a contexto de morte anunciada, afirma que o luto antecipatório não é definido pelo esforço de desligar-se afetivamente do ente adoecido, mas pelo investimento no vínculo existente.

Dentre a literatura dedicada ao estudo do luto que antecede à morte, temos um campo tratado de diversas maneiras, com as obras de Lindemann (1944), Lebow (1976), Rando (1986), Fulton e Gottesnan (1980), Pine (1986), Pincus (1989), Worden (1998), Fonseca \& Fonseca (2002), dentre outras. No primeiro item da "Parte 2" será apresentada a revisão bibliográfica da noção do luto antecipatório. 
Pode-se afirmar, no entanto, que, para todas estas perspectivas, o luto antecipatório é um problema tanto clínico quanto teórico que demanda desenvolvimentos e explicações, com lacunas a serem preenchidas, dentre as quais passo a citar algumas.

Duas grandes insuficiências podem ser apontadas: a primeira é relativa à pouca compreensão do processo de luto antecipatório vivido por familiares que têm seus entes acometidos por doenças crônico-degenerativas e que estejam em cuidados domiciliares; a segunda é relacionada à falta de métodos de intervenção clínica passíveis de serem utilizados pelos profissionais de psicologia no setting domiciliar.

Duarte, Fernandes e Freitas (2013), em seu artigo de revisão bibliográfica sobre o papel do cuidador familiar, concluíram que, no cenário nacional, o serviço domiciliar é considerado recente. Pouco se sabe sobre o fenômeno do luto antecipatório e pouco foi produzido no que diz respeito ao método de intervenção, conforme dito anteriormente. Para os autores, a demanda de cuidado não é apenas do paciente, mas também da família, e apontam que é fundamental a construção de conhecimento sobre a atuação do psicólogo neste contexto.

Minha pesquisa de doutorado é uma proposta para sanar, ao menos parcialmente, essas insuficiências. Na minha dissertação de mestrado pesquisei o percurso do luto vivenciado pelos familiares cuidadores, dialogando com o Modelo do Processo Dual (Stroebe \& Schut, 1999), um modelo recente que procura compreender como o indivíduo vivencia o processo de enlutamento. Este modelo tem sido bem difundido no âmbito internacional (Gonzaga, 2012; Parkes, 1998, 2001). No entanto, por ser um constructo teórico, não elucida sobre os aspectos técnicos do manejo do profissional de psicologia. Diante deste fato, continuamos carentes de elementos que auxiliem a clínica capaz de tratar o problema de saúde individual e coletiva apresentado nesta pesquisa.

O campo das práticas clínicas psicoterápicas é, por sua vez, também múltiplo, variado, multifacetado e, no dizer de Kuhn (1970), poderia estar sendo abordado por paradigmas díspares. Muitas perspectivas de entendimento podem ser usadas para enunciar o problema da experiência do luto antecipatório, pelo indivíduo e seus familiares, apresentando modos de cuidar (psicoterapeuticamente) dessa situação. Não me parece possível colocar a pergunta "qual a melhor ou a mais adequada?", dado que toda e qualquer perspectiva que possa enunciar esse problema na sua complexidade e apresentar uma prática efetiva de cuidado seria adequada e correta. Trata-se, para mim, no entanto, de buscar formular uma proposta heuristicamente válida, sem me preocupar com um estudo comparativo das propostas feitas até agora. Assim minha busca foi 
realizada tendo a pretensão de apresentar um modelo teórico e prático, que seja eficiente para explicar e descrever o que é situação do luto antecipatório, os problemas que são aí gerados e as propostas de manejo e cuidado que podem daí derivar, tendo em vista a sua eficiência prática na solução ou encaminhamento desses problemas dentro de um contexto de cuidado domiciliar.

Creio que a Psicologia Analítica de Carl Gustav Jung (1875-1961) seja um referencial possível de ser utilizado. A perspectiva junguiana apresenta um quadro de compreensão teórica e prática dos tratamentos psicoterápicos, ainda que não tenha sido enunciada com mais clareza no que tange o fenômeno do luto por morte anunciada. Tratase, pois, de, nessa pesquisa, desenvolver orientações de um modelo de atendimento junto a familiares que vivenciam o luto antecipatório.

Por outro lado, há algumas contribuições externas a este paradigma advindas das propostas de Donald Woods Winnicott (1896-1971) que me parecem ser relevantes e operantes no cuidado clínico dessas situações; contribuições que me parecem inserir na Psicologia Analítica a percepção de alguns fenômenos que, a meu ver, expandem e desenvolvem a maneira como a psicologia analítica poderia cuidar clinicamente desta situação, respeitadas as diferenças conceituais e paradigmáticas.

É nesse sentido que proponho, pois, minha pesquisa: depois de apresentar a perspectiva da Psicologia Analítica para abordar esse problema, desenvolvê-la com os acréscimos advindos de algumas das contribuições de Winnicott, tendo como objetivo final a apresentação de um conjunto de orientações para o tratamento dessas famílias. Este trabalho será direcionado para os trabalhadores da saúde, principalmente psicólogas e psicólogos que atuam em domicílio.

Passarei agora a apresentar alguns comentários que reforçam minha escolha pela Psicologia Analítica, trazendo brevemente alguns aspectos teóricos sobre a questão da morte e aspectos da clínica de Jung. Em seguida, apresentarei alguns pontos que justificam a inclusão de Winnicott na construção desta pesquisa e, para finalizar a introdução, realizarei um pequeno resumo acerca dos pontos que serão tratados no corpo do presente trabalho.

Jung tratou da relação do ser humano com a morte inúmeras vezes, dialogando, questionando, construindo uma teoria que pudesse auxiliar profissionais e o público em geral na compreensão e vivência desse importante fenômeno. Para o autor, a morte é um fenômeno marcante e inigualável, que impacta de maneiras diversas. A morte tem o efeito de colocar o ser humano em contato com o real sentido da vida e, diante dela, pode entrar 
em contato com sentimentos díspares, que oscilam e são extremamente opostos (Jung, 2001; 2003; 2006; 2013c; 2013g).

No trabalho de Jung (2003; 2006, 2008; 2013c; 2013e; 2013g; 20131), o tema morte é desenvolvido em duas vertentes emblemáticas: a morte como símbolo (individual e coletivo); e a morte como um aspecto da individuação, fazendo parte, portanto, do processo de desenvolvimento humano. $\mathrm{O}$ ser humano atualmente encontra-se de certa forma despreparado perante a morte, talvez porque as religiões não ofereçam recursos que preparem seus fiéis para as questões da morte (Jaffé, 1980). Jung, segundo Jaffé, ao criar a psicologia da individuação, desenvolveu indiretamente uma psicologia do envelhecimento, e individuar-se é um processo que, se vivenciado de modo profundo, pode preparar para a morte.

Para Jung, quando o indivíduo está imerso em processos de luto, seria salutar que ele entrasse em contato com aspectos simbólicos acerca da morte em sonhos, mitos, folclores, material expressivo e outros meios. Essa recomendação justifica-se porque esses elementos têm a capacidade de ajudar o enlutado a realizar associações subjetivas, organizar e ampliar sentidos que auxiliariam no manejo do luto, visto que, segundo Jung, a razão não tem a capacidade de trazer acolhimento e explicação ao contato avassalador com o fenômeno morte (Savage, 1989).

Jung privilegiava o trabalho com imagens simbólicas (Jung, 2013a, 2013c). Neste paradigma, os símbolos têm uma importância fundamental, por serem uma expressão originada do inconsciente.

Uma vez compreendida a importância vital (isto é, seu impacto benéfico ou destrutivo) dos símbolos produzidos pelo inconsciente, resta ainda o difícil problema da sua interpretação. O Dr. Jung mostrou que tudo depende de haver um "estalo", o clique necessário à correta interpretação específica em relação ao indivíduo em causa. E é dentro dessa perspectiva que ele indicou a possível significação do sonho. (von Franz, 2008, p. 210)

Os símbolos podem ser individuais e, ao mesmo tempo, comunicar o processo de desenvolvimento psíquico de um sujeito, mas os símbolos também podem ser coletivos, grupais e podem ser considerados guias para o enfrentamento de questões de difícil manejo (Penna, 2004).

No trabalho de Jung, encontramos orientações sobre o modo de tratar desse simbólico com o intuito de auxiliar o paciente no profundo processo de desenvolvimento do si mesmo e, também, em processos nos quais lida com a morte. Utilizando uma interação dialética, a clínica de Jung (2013a, 2013c) segue em um modelo face a face, bem coerente com o que é demandado no contexto do atendimento domiciliar. $\mathrm{O}$ autor 
afirma que o psicoterapeuta deve intervir ativamente e sua função não é somente aliviar a angústia, mas promover a individuação, integrando conteúdos que estão em conflito (2006; 2013a, 2013c; 2013e). Jung (2013a) afirma que, na psicoterapia, ocorre uma interação entre o sistema psíquico do paciente e do terapeuta. Sendo assim, Jung propõe que estar com o paciente requer uma relação simétrica sem hierarquizações, outro aspecto que parece ser convergente às peculiaridades e características do atendimento psicológico domiciliar.

Após esta breve apresentação do quadro de Jung, apresento os aspectos que poderão enriquecer a compreensão do processo de luto e reflexões acerca de pontos da clínica de Winnicott que poderão ser úteis na construção da presente pesquisa. A teoria psicanalítica do desenvolvimento socioemocional proposta e descrita por Winnicott chama a atenção para certos aspectos do comportamento ambiental que dizem respeito à sustentação ou aniquilação do indivíduo (Fulgencio, 2014, 2016, 2017; Loparic, 2014), o que me pareceu poder enriquecer a compreensão para tratar dos indivíduos e seus familiares em situação de luto antecipatório. Posso, desde já, elencar algumas das contribuições e/ou compreensões de fenômenos apontados e descritos por Winnicott (1971a, 1988, 1989a), que me parecem adequados à minha proposta, tais como a relação mãe-bebê, que desenvolvem no futuro os modos de ser e estar no mundo, os tipos de holding para cada caso, e a reação à intrusão (com riscos de aniquilação do verdadeiro self) frente à ameaça de morte e o desenvolvimento da capacidade de ter "fé em...", dentre outros.

O modo como Winnicott vê o desenvolvimento humano e a articulação do comportamento do ambiente, como podendo sustentar ou aniquilar os indivíduos, me pareceu ser interessante e passível de ser agregado ao modo de praticar a psicoterapia do ponto de vista da Psicologia Analítica de Jung. Creio que o indivíduo, diante de uma notícia avassaladora, como a morte anunciada, passa a reagir à intrusão do meio com o intuito de evitar a aniquilação de si mesmo. A dor provocada pela situação exige uma estrutura de ego para que não haja uma fuga patológica, na procura de falsas soluções ou ilusões. Acredito que o conceito de holding, associado a estes outros aspectos da teoria winnicottiana (continuidade de ser, invasão e/ou sustentação ambiental, sentidos de fé, verdadeiro self etc.) poderão auxiliar a construção do cuidado profissional, na medida em que psicólogas e psicólogos poderão também realizar uma sustentação ambiental frente à intrusão gerada pela ameaça de morte do ente querido. Na Psicologia Analítica se fala pouco sobre cuidado ambiental. O junguiano Louis Zinkin (1998), atuante no campo da 
prática clínica grupal, faz uma ponte entre autores da psicanálise como Folkers, Winnicott e a Psicologia Analítica.

Apesar dos autores comporem escolas (teorias) com pontos de vista e semânticas diferentes, a articulação entre eles pode ser possível, realizando-se as devidas ressalvas, que esclarecerei mais à frente quando me dedicar à análise das questões metodológicas do presente estudo. Esta é uma pesquisa teórica que visa, como resultado, uma proposta de intervenção prática. Para realizá-la farei, por um lado, um estudo conceitual estrutural da Psicologia Analítica, buscando explicitar seu modo de intervenção psicoterápica em grupo; por outro, mostrarei como algumas concepções de Winnicott podem contribuir para expandir a perspectiva psicoterapêutica da Psicologia Analítica no trato do luto antecipatório.

Nessa direção, o primeiro passo da presente pesquisa será a busca dos textos nos quais tanto Jung quanto os pós-junguianos trataram da questão do luto, do processo de individuação, bem como o conceito de símbolos, a morte como símbolo individual e coletivo, manejo clínico individual e em grupo. É importante destacar que alguns pósjunguianos serão visitados não só pelo fato de que trataram em suas obras sobre a questão do luto, mas também outros que criaram uma clínica grupal, coerente aos fundamentos da Psicologia Analítica. A leitura dos textos de Jung e dos pós-junguianos, gerará um quadro que servirá de guia para compreender o fenômeno do luto antecipatório e seu possível manejo junto ao público-alvo.

Em seguida, tratarei de buscar na obra de Winnicott a descrição que ele faz de diversos fenômenos que poderiam ser considerados no quadro da Psicologia Analítica. Se, por um lado, trata-se também de realizar uma leitura estrutural-conceitual das propostas de Winnicott, por outro, trata-se de explicitar alguns fenômenos descritos por ele. Nesse caminho, alguns autores secundários também serão visitados para auxiliar na tarefa de compreensão dos conceitos selecionados.

Tratarei de agregar os fenômenos descritos por Winnicott ao quadro de intervenção clínica elaborado segundo a Psicologia Analítica. É importante ressaltar que, ao terminar o processo de leitura e compreensão desses dois autores, terei dois quadros teóricos e clínicos distintos. De acordo com Fulgencio (2013), a utilização de uma pesquisa interparadigmática deve ser cercada de prudência, respeitando-se as disparidades de cada paradigma. Para o autor, este tipo de estudo é possível, mas aponta a necessidade de que a articulação entre dois ou mais paradigmas deve receber um 
tratamento adequado; ou seja, são os fenômenos descritos por Winnicott, e não as teorias, o material que será integrado, agregado no quadro da Psicologia Analítica.

Sendo assim, eu me manterei no quadro da Psicologia Junguiana, mas o expandirei com as contribuições de Winnicott, na construção das contribuições para o modelo de intervenção junto a grupo familiar. A insistente postura de manter os paradigmas em suas "línguas originais" deve-se ao fato de que muitos conceitos, como self, consciente, inconsciente e outros, são irreconciliáveis entre junguianos e psicanalistas. Contudo, mesmo havendo problemas de comunicação no exercício de articular os dois saberes, essas dificuldades serão devidamente tratadas no desenvolvimento da pesquisa. Realizada a tarefa de esclarecer como o processo de sustentação teórico e clínico pode acontecer, passarei para próxima parte do estudo.

Com relação ao desenvolvimento das orientações do modelo de intervenção psicoterápica para a atuação junto a familiares em luto antecipatório em domicílio, passarei a formular algumas orientações para atuação clínica do psicólogo domiciliar que atende famílias que vivem uma morte anunciada. Devo novamente pontuar que a base clínica de tal modelo será a Psicologia Analítica, porém esta receberá as contribuições do quadro de Winnicott.

Para desenvolver as diretrizes, precisarei de um método de trabalho. Este será pautado numa ordem de necessidade, indo das bases teóricas à prática em si. Não se trata de criar uma oficina, ou uma única sessão em grupo, mas criar orientações que poderão contribuir para a ação de psicólogas e psicólogos nesse modelo domiciliar que ainda está em construção.

Para alcançar tal meta, descreverei o papel do psicólogo neste contexto, dando destaque aos parâmetros que deverão nortear seu olhar e sua ação ao entrar no domicílio, bem como os aspectos éticos que deverão permear sua prática. Outro ponto que também deverá receber atenção é a definição das atribuições do psicólogo frente às famílias e sua interação com a equipe multiprofissional.

Definidos os parâmetros iniciais, partirei para a descrição do corpo do tratamento, como os pontos relativos à formação de um bom rapport entre profissionais e familiares, como será realizada a composição do diagnóstico psicossocial situacional realizado in loco e os objetivos do tratamento. O próximo passo será o levantamento dos recursos e materiais passíveis de serem aplicados, bem como apontamentos sobre o formato, tempo e frequência da intervenção, e outros pontos que surgirão durante a pesquisa. É importante reforçar que o desenvolvimento desta etapa será marcado pelo diálogo com a contribuição 
dos autores escolhidos, destacando o que a Psicologia Analítica (Jung e os pósjunguianos) poderá emprestar para esta ação. Serão destacados também os diálogos com a obra de Winnicott.

Por fim, espero que, ao tratar deste conjunto de questões, seja possível ter delineado uma ação psicoterápica que possa ser útil e passível de ser aplicada por psicólogos em contexto domiciliar. Para a socialização do que foi construído até aqui, passarei para a fase de confecção de um folheto informativo contendo as principais orientações do trabalho. Este material terá o objetivo de orientar usuários e profissionais sobre o luto antecipatório e possíveis formas de manejos e poderá ser distribuído nas unidades de saúde, tanto públicas quanto privadas.

Esta pesquisa também poderá acrescentar recursos na formação profissional de psicólogas e psicólogos no que diz respeito ao entendimento e tratamento do luto. E em última instância, este estudo tem o intuito de fornecer um arcabouço teórico que poderá contribuir na formulação de políticas públicas voltadas para esta questão, visto que o sofrimento de familiares em luto antecipatório é um problema real que ainda carece de legislação e programas de proteção.

Apresentando um passo a passo da pesquisa, tratarei de descrever os objetivos de cada capítulo, tendo em mente as maneiras como farei, como e onde pretendo chegar. A tese está dividida em duas partes: na primeira parte, irei me dedicar aos fundamentos teóricos dos autores tratados; na segunda parte, irei trabalhar com a prática, trazendo conteúdos e reflexões relacionados à questão da clínica. Sendo assim, no primeiro item dos Fundamentos, meu objetivo é apresentar alguns teóricos que trataram da questão do luto e como estes entendem a vivência de tal processo, tanto na saúde quanto na patologia. Em seguida, tratarei dos aspectos gerais do luto, contexto e processos. No terceiro subitem, trarei a noção do luto antecipatório para a literatura especializada, suas contradições, bem como ele é vivenciado no contexto das doenças crônico-degenerativas em domicílio. Ainda neste item, realizarei uma breve reflexão relacionada ao que a literatura especializada entende por "morte domada", "morte interdita" e "morte anunciada". Em seguida, apresentarei o novo contexto das doenças crônicas e, também, a noção do que é o atendimento em domicílio, passando pelo seu histórico, pela breve apresentação de sua padronização no Sistema Único de Saúde, as implicações do trabalho em uma equipe multiprofissional, bem como as características e peculiaridades do trabalho psicológico no contexto da assistência domiciliar. Para finalizar, abordarei o 
manejo psicológico em contexto de luto antecipatório realizando a discussão sobre a quem se destina este tipo de cuidado.

$\mathrm{Na}$ segunda parte dos "Fundamentos", serão apresentados os aspectos gerais da Psicologia Analítica, o modelo ontológico de homem/mulher para Jung, a teoria do desenvolvimento humano do ponto de vista de Jung e o processo de individuação. O objetivo é introduzir uma noção do arcabouço teórico produzido por Jung para auxiliar na compreensão do processo de luto. $\mathrm{Na}$ segunda parte deste item, apresentarei as contribuições de Jung para a compreensão do enlutamento, demonstrando como o autor aborda os aspectos do luto de si e do outro afetivamente vinculado, a perspectiva simbólica da morte em sonhos e mitos.

No terceiro subitem, tratarei das contribuições de Winnicott para a compreensão do luto. Para tanto, apresentarei um quadro geral da teoria psicanalítica de Winnicott descrevendo os aspectos gerais, o modelo ontológico de ser humano para o autor, e a teoria do desenvolvimento socioemocional a partir de seu ponto de vista. Na sequência, aproximarei o autor das questões do luto a partir da perspectiva dos modos de ser/estar e relacionar-se nas diversas fases do desenvolvimento emocional. Aqui também serão tratadas: a experiência da primeira morte, a construção da capacidade de ter "fé em..." e a esperança, a noção de continuidade do SER versus quebra nessa continuidade (intrusão e aniquilação do SER), a vivência das angústias impensáveis e os impactos no processo de luto.

Encerradas as apresentações e discussões teóricas, passarei para a terceira parte da pesquisa que dedicarei às apresentações das práticas clínicas da Psicologia Analítica e de Winnicott. Na primeira etapa tratarei, dentro da perspectiva analítica, o processo terapêutico individual, seguido do manejo da terapia individual junto a pacientes em luto e, por fim, o processo terapêutico em grupo. No segundo item, tratarei das contribuições relacionadas à clínica da Psicanálise do ponto de vista de Winnicott sobre este cuidado psicoterapêutico. Por fim, apresento as considerações sobre a atuação clínica junto a familiares em luto antecipatório em contexto domiciliar, a partir do quadro da Psicologia Analítica com contribuições de Winnicott. Para finalizar o corpo da tese, encerro com a apresentação das considerações finais, retomando sinteticamente todo o percurso feito e apresentando as últimas reflexões acerca da proposta aqui apresentada. Em apêndice, incluo um produto técnico criado em forma de folheto para ser distribuído em unidades de saúde como em salas de espera em hospitais, clínicas, bem como ser distribuído nas 
redes sociais por meio eletrônico, contendo reflexões pertinentes à questão do luto antecipatório e seus cuidados. 


\section{FUNDAMENTOS}

No presente item serão apresentados os fundamentos teóricos que subsidiaram a presente pesquisa. Para tanto trato dos constructos advindos da literatura especializada acerca do tema luto, luto antecipatório e atendimento domiciliar. Em seguida apresentarei conceitos da Psicologia Analítica e reflexões pertinentes para a compreensão do processo de luto, e luto antecipatório. Em seguida acrescentarei os constructos advindos da psicanálise de Winnicott no intuito de ampliar a discussão pretendida nesta tese.

\subsection{Luto Antecipatório: definição, descrição e estado atual do conhecimento}

Neste item dou início à apresentação mais aprofundada do tema luto antecipatório e as interfaces do contexto da presente pesquisa. Aqui será tratada a noção de luto para alguns autores, aspectos gerais do processo de luto normal e patológico. Na sequência, tratarei da noção de luto antecipatório, e as peculiaridades de quando ele acontece e é cuidado no contexto de doenças crônico-degenerativas. Em seguida, iniciarei a discussão sobre o atendimento domiciliar realizado pelo profissional de psicologia e apresento como o luto antecipatório tem sido tratado atualmente.

\subsubsection{Luto antecipatório de familiares em contexto de cuidados domiciliares: uma problemática para a Psicologia}

Para construir um quadro a partir do qual se possa olhar o processo de luto antecipatório dos familiares de pacientes graves, que estão em cuidados domiciliares, precisarei apresentar uma série de constructos elaborados pela literatura especializada até então. Aqui tratarei teoricamente da noção de luto e luto antecipatório, indo das bases teóricas gerais que tratam sobre os conceitos sobre o luto e seus processos, passando em revista as reflexões sobre as especificidades do luto antecipatório, as várias formas de ver a morte e o morrer, e as especificidades do atendimento dessa demanda para a psicologia domiciliar em equipes multiprofissionais. Não se trata de apresentar todas as teorias 
existentes, mas de trazer um corpo consistente sobre a questão do luto para dar seguimento aos objetivos desta tese.

\subsubsection{Bases teóricas: contribuições para a compreensão do processo de luto, um recorte teórico}

Para iniciar o trabalho sobre os fundamentos teóricos que cercam a questão do processo de luto, farei um recorte intencional apresentado uma bibliografia selecionada contendo alguns dos teóricos que trataram sobre a questão do luto na história da Psicologia. O objetivo deste procedimento é auxiliar na elaboração do quadro em que será construída a presente pesquisa. Dentre os diversos autores que contribuíram direta e indiretamente para a reflexão relativa ao fenômeno luto, seleciono os seguintes: Sigmund Freud (1917e), Carl Gustav Jung (20131), John Bowlby (1973), Cicely Saunders (1990), Elizabeth Kübler-Ross (1996) e Donald Woods Winnicott (1990). Eles serão apresentados obedecendo uma orientação cronológica.

Em 1917, Sigmund Freud [1856-1939] publica a pioneira obra Luto e Melancolia. Seu estudo redigido originalmente durante a I Guerra Mundial foi baseado em observações clínicas no qual defende que a melancolia resulta, basicamente, de uma perda cujo luto não foi objeto de elaboração psíquica. De acordo com Freud (1917e), tanto o luto quanto a melancolia se originariam de perdas de objetos libidinalmente investidos. Tanto um quanto o outro provocariam no sujeito um profundo desânimo, além de um desinteresse pelo mundo externo.

Para Freud (1917e), a diferença marcante entre esses dois estados é que na melancolia haveria uma degradação importante na autoestima por razões relacionadas ao empobrecimento do ego; no luto, por outro lado, o sujeito sentiria o mundo externo empobrecido. $\mathrm{O}$ autor não considerou a priori o luto como uma situação psicopatológica, e inovou ao refletir sobre as diferenças do luto "normal" e "patológico", bem como ao descrever uma teoria sobre o processo de enlutamento.

Em 1934, Carl Gustav Jung [1875-1961] publicou A alma e a morte (20131). Neste trabalho, Jung apresentou suas reflexões sobre a relação do ser humano com a finitude e a relacionou com o desenvolvimento humano, também dando pistas sobre aspectos patológicos e saudáveis. Segundo o autor, não é fácil lidar com a morte, nem mesmo quando se está vivendo a velhice. Neste trabalho o autor traz a relação da individuação com a questão do morrer e aborda a fé/religiosidade e a simbologia como formas mais 
interessantes, profundas e relevantes de se experienciar e lidar com a morte. Jung trouxe, ainda, experiências da clínica a partir da análise de sonhos de pacientes que estavam em processos tanatológicos.

Outro autor que contribuiu com a desenvolvimento da literatura especializada sobre o luto foi o psiquiatra e psicanalista inglês John Bowlby [1907-1990]. O autor formulou a Teoria do Apego com o intuito inicial, na década de 1950, de esclarecer os efeitos da privação materna no desenvolvimento infantil, tendo constatado que a maneira como uma criança lida com a presença e a ausência da mãe influenciará seu posicionamento em situações futuras de estabelecimento e rompimento de vínculos. Consequentemente, o referido autor, ao concluir seu modelo teórico, já na década de 1980, pode estabelecer evidências de que os padrões de apego são determinantes para os padrões de luto (Parkes, 2009). Justamente por essa razão, Bowlby é considerado, conforme Franco (2002), um dos principais expoentes sobre o assunto.

Detalhar a Teoria do Apego em toda a sua amplitude foge ao escopo do presente estudo, de modo que optamos por contemplar aqui apenas uma de suas conclusões, a qual estabelece que os enlutados apresentam comportamentos semelhantes e atravessam fases durante este processo: entorpecimento, anseio e busca, desorganização e desespero e, reorganização (Bowlby, 1984a, 1984b). Tais fases serão descritas no decorrer deste capítulo.

A partir das décadas de 1950 e 1960, devido a importantes mudanças históricas e epidemiológicas, a assistência aos moribundos ocorria com distanciamento afetivo nos corredores gelados dos hospitais. O atendimento contemplava apenas o cuidado biológico, sendo negligenciadas as dimensões emocionais, sociais e espirituais. Cicely Saunders [1918-2005] (1990) e Elizabeth Kübler-Ross [1926-2004] (1996; 1998b) iniciaram um marcante trabalho com pacientes terminais. Segundo Kovács (2008), estas duas personalidades foram grandes revolucionárias no campo da Tanatologia por proporem, mesmo sendo considerado um tema tabu, a discussão pública sobre a questão da morte e do morrer.

Cicely Saunders foi uma enfermeira, assistente social e médica inglesa. Ela publicou constructos fundamentais para a orientação do trabalho técnico em cuidados paliativos, e foi criadora do primeiro Hospice do mundo em 1967. De acordo com Cardoso (2009), Matsumoto (2009), Maciel (2008), Solano e Bifulco (2018), Saunders contribuiu para a compreensão dos profissionais acerca das necessidades dos doentes terminais e sobre alívio da dor e dor total. Para esta pioneira, o indivíduo classificado 
como estando fora de possibilidades terapêuticas de cura precisava ser assistido em suas diversas necessidades. Ela afirmava que o sofrimento em todas as suas dimensões pode ser acalentado se o sentimento de solidão e a negligência forem acolhidos.

De acordo com Maciel (2008) para Saunders, o objetivo nos Hospices não seria o tratamento visando a cura de um órgão, ou mesmo ações obstinadas a combater à morte. Nestes locais, o paciente poderia ter seu processo de morte respeitado, já que os cuidados paliativos primam pelo cuidado global, partindo da premissa de que o indivíduo é um ser integral, e que devem ser respeitados os aspectos subjetivos, espirituais e físicos.

... Esse é o real trabalho dos profissionais de cuidados paliativos. Controlar sintomas, sim, sempre! Não se pode focar no positivo quando a dor é insuportável. É preciso aplacar o sofrimento físico, mas é necessário ir muito além. A 'cura' como 'ser humano' pode existir mesmo quando a 'cura' biológica parece utópica. Não se trata de restaurar um sistema orgânico, biopsíquico, mas muito mais que isso, é necessário encontrar o significado para a existência. Afinal, como dizia Viktor Frankl: 'Nada proporciona melhor capacidade de superação e resistência aos problemas e dificuldades em geral do que a consciência de ter uma missão a cumprir na vida'. O ruim não é morrer, mas morrer sem que a vida tenha um significado. (Caponero \& Bifulco, 2018, p. 14)

Contemporânea de Sauders, a psiquiatra suíça Elisabeth Kübler-Ross contribuiu para a mudança no cenário do atendimento ao paciente, promovendo, conforme Kovács (2003a), a rehumanização do processo de morrer. Para a Kubler-Ross (1998b, p. 15): “a morte pode ser uma das maiores experiências que se pode ter. Se você vive bem cada dia de sua vida, não tem o que temer”. A partir de conversas íntimas e profundas com pacientes terminais, a autora foi desenvolvendo um aporte teórico que pode auxiliar a compreensão dos aspectos psicológicos, sociais, espirituais do processo de morrer. Para Kübler-Ross (1998b) no período que antecede ao óbito, pacientes portadores de doenças graves e seus familiares apresentavam um conjunto de reações emocionais naturais que puderam ser agrupadas em cinco fases: negação ou isolamento, raiva, barganha, depressão ou interiorização e aceitação.

De acordo com a autora, tais fases também poderiam ser vivenciadas, antes e após a morte, pelos familiares dos pacientes e, até mesmo pelos profissionais de saúde, rehumanizando também estas relações afetivas. Sendo assim, a referida autora demonstrou que o luto deve ser encarado por todos como um processo vital e humano. Torres (1998) defende que, por essa razão, Kübler-Ross foi uma porta voz da subjetividade tão esquecida no ambiente hospitalar e que seu trabalho representou a retomada da ética e da dignidade na assistência aos moribundos. 
Existem autores que puderam acrescentar contribuições relevantes, mesmo não tendo como foco a busca de respostas relativas à compreensão do processo de enlutamento em si. Um destes autores foi Donald Woods Winnicott [1896-1971] com sua teoria sobre o desenvolvimento humano. Este autor pode auxiliar na reflexão da relação do sujeito com a morte a partir da publicação de Natureza Humana, em 1990. Neste trabalho ele aponta que o ser humano vive um continuum que percorre desde a existência na barriga da mãe até o último adeus. Para Winnicott, no início da vida o bebê (do útero ao início da vida) ainda não está integrado, sendo que não existe um vínculo entre o corpo e a psique, e "não há um lugar para uma realidade não-EU” (Winnicott, 1990, p.153). Em teoria, este estado é original, mas não padronizado ou planificado. Segundo Winnicott, esta não é uma verdade, pois, na prática, existe um bebê sendo cuidado, física e psiquicamente cuidado, em um ambiente profundamente adaptado a ele. No início do desenvolvimento humano, a dependência do ambiente é absoluta, não havendo utilidade tratar do bebê enquanto um ser único, individuado, a unidade que se apresenta nessa fase do desenvolvimento é o amalgama bebê/mãe-ambiente. Neste grau de dependência "ainda não existe ali um self individual capaz de discriminar entre o EU e o não-EU” (p. 153). Então o autor pergunta: "qual é o estado do indivíduo humano quando o ser emerge do interior do não-ser? Onde fica a base da natureza humana em termos do desenvolvimento individual? Qual o estado fundamental ao qual todo ser humano, não importe sua idade ou experiências pessoais, teria que retornar se desejasse começar tudo de novo?" (p.153).

Até este momento apresentei alguns teóricos que irão, como dito anteriormente, auxiliar na construção deste trabalho. Em seguida realizarei a apresentação dos aspectos gerais do luto, contexto e processos que constituem este fenômeno. Para tanto, tratarei de dar foco nos conceitos necessários para esclarecer o quadro a partir do qual observaremos.

\subsubsection{Apresentação dos aspectos gerais do luto, contexto e processos}

O termo "luto" geralmente é empregado tanto na literatura científica quanto no senso comum para designar a reação de um sujeito a uma perda significativa. O luto em sentido amplo é um processo adaptativo, dinâmico, que pode estar relacionado a mudanças de ciclo vital e não necessariamente a situações negativas. Ao vivenciar uma mudança substancial, como, por exemplo, uma mudança no estado civil, uma promoção profissional, ou mesmo a ida de um filho para a faculdade, podem ser desencadeados 
processos de luto que auxiliarão o sujeito no enfrentamento e nos ajustes a nova realidade (Bromberg , 1997; Fonseca, 2004; Parkes, 1998).

$\mathrm{Na}$ presente pesquisa, utilizarei o termo "luto" de acordo com as especificações de Parkes (2009), que considera tal fenômeno uma reação a uma perda que está relacionada à morte. O luto é um processo vivenciado individual e socialmente, e está relacionado com o enfrentamento de uma crise por perda de algo/alguém afetivamente vinculado (Kübler-Ross, 1996, 1998b; Parkes, 1998; Kovács, 2008). O campo de influência é amplo e pode não só impactar os indivíduos isoladamente, mas também o sistema familiar como um todo (Bromberg, 1997).

De acordo com Kovács (1992), o medo da morte é uma reação comum, sendo considerada uma resposta psicológica universal. A autora aponta que, em geral, a estrutura psíquica do ser humano reage com o sentimento de medo ao fenômeno da morte. Esse medo está relacionado à perda de controle, ao medo de ficar só, de ser julgado por atitudes anteriores, de não concretizar sonhos etc. Em se tratando de perda por morte, as perdas são inumeráveis... não sabemos ao certo o que se perde quando se perde alguém... Para Parkes, a morte de um ente querido "demanda energia psíquica para lidar com aspectos nela envolvidos. Mais importante que definir a morte, é necessário, inclusive, considerar o luto como processo que o indivíduo vivencia pela morte do outro, pois 'em qualquer luto, raramente fica claro com exatidão o que foi perdido'” (Parkes, 1998, p. 24).

Os estudos científicos sobre o tema têm sido realizados com certa regularidade a partir das Grandes Guerras Mundiais (Parkes, 2001). Tal momento histórico ocasionou uma mudança na forma de se relacionar com a morte, o que propiciou certo atravessamento na forma de pesquisar. Sendo assim, num primeiro momento, os autores contemplavam fundamentalmente as questões intrapessoais do luto, como, por exemplo, os pensamentos e os sentimentos de indivíduos enlutados, pois se almejava compreender os impactos da morte na vida do sujeito. Contudo, a partir de 1990 ocorreu uma ampliação desta perspectiva e assim foram incluídos aspectos interpessoais do luto como os padrões de relacionamento anteriores à morte e as condições socioculturais dos sobreviventes. Tais mudanças poderiam dessa forma enriquecer ainda mais a compreensão do fenômeno (Stroebe et al., 2001).

Parkes (2001) acrescenta ainda que, no final do século XX, as pesquisas desenvolvidas na Europa e nos Estados Unidos da América apresentavam dois enfoques principais, ambos de grande relevância. Uma parte delas explorava as consequências 
biopsicossociais de perdas, ao passo que outra parte relacionava os processos de formação e rompimento de vínculos. O referido autor destaca que a integração desses enfoques poderia viabilizar o aprofundamento do conhecimento científico disponível sobre o luto, mas admite que a existência de uma certa fragmentação nesse campo de pesquisa está relacionada, principalmente, ao fato de que tal fenômeno seja caracterizado pela multidisciplinaridade.

O esforço em compreender o fenômeno auxiliou na categorização de algumas variações de luto, como o luto normal versus complicado, e luto crônico versus inibido. É importante esclarecer que o termo "luto patológico" tem sido preterido recentemente, na medida em que este remete a uma diferenciação inflexível entre o que seria "normal" e "anormal" no processo de luto. Desse modo, o termo "luto complicado" vem sendo empregado para fazer referência ao luto que não teve um curso bem sucedido, e que oferece riscos, já que não houve uma elaboração satisfatória da perda que o provocou (Bromberg, 1997; Mazorra, 2009).

Nesse sentido, o luto complicado compreende duas modalidades: crônico e inibido. No entanto, para melhor compreensão das características desses desenvolvimentos, torna-se necessário apresentar como se dá o processo de luto “normal”. As aspas utilizadas tornam tangível a reflexão entre o que é normal do que seja geral, comum, já que, apesar do luto apresentar um padrão comum, que pode ser observado em grande parte das pessoas que o vivenciam, ele é essencialmente um processo individual e subjetivo (Pine, 1986; Stroebe et al., 2017) .

Segundo Parkes (1998), um luto pós-óbito sem complicações é constituído em linhas gerais pelas seguintes fases: entorpecimento, anseio e protesto, desespero, recuperação. Muitos autores chegaram a mais ou menos a mesma classificação, tais como Bowlby (1973, 1984a, 1984b, 1990), Kübler-Ross ${ }^{1}$ (1998b) e outros.

Descreverei a contribuição do primeiro autor, mas em alguns momentos aproximarei sua teoria das contribuições de Kübler-Ross e Parkes, com o intuito de compreender o processo de luto normal e, em seguida, apresentarei o Modelo do Processo

\footnotetext{
${ }^{1}$ É importante apontar as reflexões realizadas acerca da origem do modelo de fases. De acordo com Stroebe et al (2017) as ideias que compõem o modelo de fases foram levantadas em primeiro lugar por Bowlby (Archer, 1999; Bonanno, 2009; Parkes, 2013, citado por Stroebe, 2017 et al). De acordo com Parkes (2013 citado por Stroebe et al., 2017) Kübler-Ross falhou ao afirmar no livro Sobre a morte e o morrer que ela havia descoberto os "estágios do luto". Para Parkes tal afirmação não procederia visto que esses estágios foram originados nas pesquisas desenvolvidas por James Robertson e John Bowlby junto a crianças separadas de sua mãe (Robertson \& Bowlby, 1952) e aplicado por Bowlby e Parkes (1970) em adultos enlutados. De acordo com os autores Kübler-Ross conhecia estas pesquisas, contudo não as mencionou.
} 
Dual e suas contribuições. A primeira fase do luto se instala, tipicamente, quando acontece a notificação do óbito, e tem duração imprecisa, podendo variar de poucas horas a muitos dias. $\mathrm{O}$ enlutado experimenta uma sensação de que a situação que vivencia não é real e a negação é empregada em larga escala. Mas deve-se salientar que a evitação de sentimentos também pode ocorrer, até mesmo de forma consciente, pois o indivíduo está diante de uma dor física e psicológica de proporções gigantescas. Algumas semelhanças, como dito anteriormente, podem ser identificadas entre a fase de entorpecimento, tal como descrita pelo referido autor, e a fase de negação ou isolamento observada por Kübler-Ross (1998b).

Já na fase de anseio e busca, o enlutado, segundo Bowlby (1990), sofre momentos de abatimento e languidez quando a consciência da perda começa a se impor, de modo que apresenta episódios de aflição e choro intenso. Além disso, uma agitação associada a lembranças faz com que o indivíduo busque sinais da presença da pessoa querida, permanecendo muitas vezes atento a qualquer possibilidade de reencontro. Parkes (1998) esclarece que esse comportamento pode se refletir em uma movimentação contínua e acelerada. Mas, diante da frustração provocada pela constatação da irreversibilidade da perda, surgem manifestações de protesto.

Tais manifestações cedem lugar à desmotivação generalizada que marca a fase de desorganização e desespero. O enlutado, assim, não encontra forças sequer para resoluções práticas necessárias à vida cotidiana (Bowlby, 1973). Logo se torna, como bem observou Delalibera (2010), apático e fechado às relações. Concomitantemente, nessa fase o indivíduo pode, ainda que de forma pontual, demonstrar certas atitudes que sinalizam tentativas de evitação de lembranças, desfazendo-se de objetos particularmente representativos da pessoa querida que se foi, por exemplo. Atitudes desse tipo podem criar condições para a reorganização da vida, desde que não ocorram prematuramente.

O enlutado paulatinamente passa a compreender a importância de adotar novos papéis e investir em novas habilidades. Dalbem e Dell'Aglio (2005) apontam que isso é possível quando o mesmo reconstrói o vínculo com a pessoa querida que se foi. Segundo Bowlby (1993), esse processo caracteriza a fase de reorganização, assim como a retomada gradativa do interesse pelo meio. Tal fase, para Parkes (1998), implica em uma revisão de uma série de concepções do indivíduo que se apoiavam na existência anterior da pessoa que faleceu e enseja uma mudança de identidade em seu sentido mais amplo.

Sendo assim, o luto deve ser encarado por todos como um processo vital e humano (Kovács, 2003a). A noção de "fases do processo de morrer", como mencionado, foi 
interpretada literalmente, mas é preciso esclarecer que nem Kübler-Ross, nem Bowlby trabalhavam com a ideia de uma ordem fixa, cronológica, admitindo, assim, que a sequência de reações emocionais desencadeadas pela morte não pode ser prevista com exatidão, seriam considerados modos de reação no enfrentamento da perda. Além disso, deve-se salientar que os referidos autores entendiam que a noção de "fases do processo de morrer" não constitui um modelo teórico sobre o luto.

A despeito disso, a noção de "fases do processo de morrer" foi interpretada, tanto no meio acadêmico quanto no meio clínico, de modo literal, o que resultou em um reducionismo da complexidade inerente ao enlutamento. De acordo com Stroebe, Schut e Boerner (2017), tal constructo traz riscos por ser simplista, confuso, superficial em sua dimensão teórica e clínica, gerando consequências devastadoras quando utilizado como diretriz por profissionais que o tomam por regra no apoio aos enlutados. A simplicidade dos conceitos frente ao fenômeno complexo do luto encanta profissionais e teóricos até os dias atuais. Contudo esse "modelo de fases" pode, de acordo com os autores, interferir no desenvolvimento do processo de luto com violências, já que pode levar o enlutado a duvidar se está ou não vivenciando o processo de modo apropriado. Outro ponto relevante trazido pelos autores é que o modelo de estágios não auxilia na identificação daqueles que estão em risco de complicações no processo de luto de acordo com o DSM-5 (Manual Diagnóstico e Estatístico de Transtornos Mentais), o que não auxilia no desenvolvimento do olhar mais apurado dos profissionais de saúde que são treinados para identificar esses sentimentos e cognições nos seus pacientes.

A partir do final da década de 1990, como dito anteriormente, houve uma incorporação dos aspectos intrapessoais nas pesquisas sobre o luto. De acordo com Stroebe et al. (2017) houve uma ampliação dos modelos teóricos que buscavam compreender o processo de luto. Os autores afirmam que estes são alguns exemplos que poderiam ser mais interessantes e mais apropriados para serem utilizados na compreensão do processo de luto. Existem várias perspectivas científicas alternativas que representam melhor o curso do pesar e do luto, como apontado por Stroebe et al. (2017) na Tabela 3:

- O objetivo dos modelos teóricos é compreender (e tentar explicar) o processo de luto, não ser prescritivo sobre o que as pessoas têm que passar.

- Existem perspectivas científicas alternativas que representam melhor o curso do luto e do pesar por exemplo, abordagem de trajetórias (Bonanno, 2004), teoria do estresse cognitivo (Folkman, 2001), abordagem da construção de significado abordagem (Neimeyer, 2001), modelo de transição psicossocial (Parkes, 1971), modelo de duas vias (Rubin, 1981), modelo de processo dual (Schut \& Stroebe, 1999), novo modelo de luto (Walter, 1996) e tarefa modelo (Worden, 1982). Para 
uma revisão, consulte Stroebe e Schut (2001). (Stroebe, et al., 2017, p. 465). [tradução minha].

Visto isso, pode-se observar a quantidade de teorias e de modelos criados até então para a compreensão do processo de luto, além dos constructos tradicionais apresentados até aqui. Passo agora a apresentar sucintamente o Modelo do Processo Dual criado por Stroebe e Schut (1999). Os pesquisadores holandeses partem do princípio de que as teorizações existentes até então apresentavam limitações importantes, uma vez que enfatizavam a centralidade da noção psicanalítica de "trabalho de luto" e, assim, desconsideravam outros aspectos importantes do enlutamento (Stroebe et al., 2001).

No Modelo do Processo Dual, um dos constructos originados dessa linha de pensamento incorpora essa noção, mas a amplia, incluindo outras vertentes teóricas, dentre as quais se destaca a teoria cognitiva do estresse. Para tal grupo de pesquisadores, um processo de luto adequado, deve conter um movimento dinâmico e regulatório que permita uma oscilação entre a orientação para a perda e a orientação para a restauração. O enfrentamento orientado à perda engloba a noção de "trabalho de luto" e a busca da pessoa perdida, de modo que se refere à vivência da perda propriamente dita, que é entendida como estressor primário. No conjunto de situações que englobam a orientação para a perda tem-se, além do trabalho de luto, a intrusão de luto, a vivência da quebra de laços e ligações, bem como a deslocalização da pessoa falecida. É também vivenciada a negação e a evitação das alterações de restauração. Sendo assim, esse tipo de enfrentamento se traduz na expressão da dor decorrente da morte, a partir do exame de seus pormenores. Neste processo pode ser envolvido até mesmo a negação das mudanças implementadas pela perda (Stroebe et al. 2001).

Já o enfrentamento orientado à restauração, segundo os autores, refere-se à reorganização da vida, que é entendida como estressor secundário. Logo, esse tipo de enfrentamento inclui o estabelecimento de novas relações e, também, a necessidade de atendimento de mudanças na vida, a experiência de realizar novas atividades, bem como a distração do pensamento que recorda a perda, a negação e evitação da dor, o desenvolvimento de novos papéis, identidades e o estabelecimento de novos relacionamentos.

Considera-se, portanto, que a alternância entre o enfrentamento orientado à perda e o enfrentamento orientado à restauração é essencial para a construção de significados positivos sobre o luto, como bem observou Mazorra (2009). E essa alternância, conforme 
Silva (2004), não poderia ser concebida tão claramente a partir da noção de "fases do processo de morrer" de Kübler-Ross ou dos constructos de Bowlby.

Todas as contribuições apresentadas até aqui seguem positivamente auxiliando na compreensão do fenômeno do luto, oferecendo embasamento para que o profissional de saúde possa interpretar e, se necessário, intervir junto aos indivíduos que apresentem expressão de luto normal. Contudo, a literatura especializada pode assessorar principalmente em casos em que ocorrem complicações no transcorrer deste processo. Parkes (1998) afirma que muitas pessoas se encaminham ao médico após uma perda queixando-se de sintomas que muitas vezes estão relacionados a expressões do próprio luto. Tais incômodos podem estar relacionados a sintomas próprios de um quadro de ansiedade, como insônia, taquicardia, mudanças de humor repentinos e outros. O luto desencadeia uma série de sintomas físicos, emocionais, de interação social e, também, pode interferir nas dimensões cognitivas e espirituais (Franco, 2002).

Parkes (1998) pondera que o luto pode ser considerado um "processo psicológico distinto" (p. 24) e ainda é pouco tratado como deveria ser, mas pondera que

Parte da dificuldade de colocar o luto entre as categorias de doenças descritas deriva do fato de ele ser um processo e não um estado. Não é um conjunto de sintomas que tem início depois de uma perda e, depois, gradualmente se desvanece. Envolve uma sucessão de quadros clínicos que se mesclam e se substituem. (Parkes, 1998, pp. 23-24)

Por outro lado, a supervalorização do luto e a tentativa de diagnosticar o indivíduo em detrimento de sintomas subjetivos também se torna uma temeridade. Para tanto existe a necessidade de uma avaliação cuidadosa para se identificar a presença de riscos relativos à vivência de um luto complicado para não incorrer em erros com intervenções desnecessárias, já que de acordo com Kovács (2008), Rando (1993), Parkes (1998) e Bromberg (1997), muitas vezes a avaliação não é feita a contento por falta de preparo do profissional. Tal situação pode convergir em consequências graves, como o erro classificatório, fechando diagnósticos sem incluir adequadamente o contexto de enlutamento.

É preciso sempre levar em consideração a subjetividade e a individualidade de cada enlutado. Ao analisar o conteúdo trazido pelo indivíduo e/ou familiares enlutados, os profissionais têm condições de averiguar se há ou não indícios de luto complicado. De acordo com Kovács (2008), a negação e repressão da dor relacionadas à perda são fatores que podem interferir complicando o desenvolvimento do processo como um todo. Para a autora, não podemos ignorar o caráter individual, pois cada pessoa irá vivenciar o pesar em seu próprio tempo, não existindo padrões cronológicos ou normatizações aplicáveis. 
Isso sem contar o tipo de morte que provocou a perda, e a idade dos envolvidos, ou seja, uma morte trágica por acidente ou suicídio impregnarão aspectos peculiares ao processo de pesar, bem como se o ente que morreu foi, por exemplo, um filho jovem.

Existem inúmeras variáveis que influenciam e perpassam o desenvolvimento do luto complicado. Segundo Kovács (2008):

... Entre os fatores complicadores deste processo deve ser considerada a relação anterior com o falecido, principalmente a que envolve ambivalência e dependência, problemas mentais e a percepção da falta de apoio social. O luto complicado pode se manifestar por sintomas físicos e mentais. Em muitos casos é difícil separar um processo de luto complicado e a presença de problemas mentais. Esta diferenciação é fundamental ao se pensar nas formas mais adequadas de cuidado (Kovács, 2008, p. 460).

Mas afinal, o que é um luto complicado crônico ou mesmo inibido? O luto crônico é definido por Parkes (1998) como aquele que se perpetua por muitos anos, provocando intenso sofrimento emocional por manter o indivíduo excessivamente ligado a lembranças do ente que partiu. Este modo é caracterizado pelo predomínio de sintomas como ansiedade, tensão, inquietação e insônia (Bromberg, 1997).

Já o luto inibido, ainda segundo Parkes (1998), tem como principal característica a negligência da vivência da perda. Uma das características é o adiamento das reações de luto, conscientes ou inconscientes. Em suas pesquisas o autor encontrou "pessoas que se queixavam de insônia, ataques de pânico, rompantes de raiva irracional e afastamento social. No entanto, esses sintomas podem ocorrer após um período de adiamento e não são suficientes para levar a indicação de auxílio psiquiátrico" (Parkes, 1998, p. 137). Nesse sentido o luto complicado (inibido ou crônico) deve ser observado, e nesse caso pode demandar intervenção profissional.

Sob o ponto de vista do Modelo do Processo Dual, em contrapartida, as dificuldades ou a exacerbação no enfrentamento orientado à perda ou no enfrentamento orientado à restauração pode indicar a necessidade de ação profissional. Afinal, o indivíduo que não abre mão da busca da pessoa perdida tende a sofrer os efeitos de um luto crônico, ao passo que aquele que evita o pesar e se engaja excessivamente na reorganização da vida se coloca em situação de risco para o desenvolvimento de um luto inibido (Parkes, 2009). Gonzaga (2012) aponta que a observação da qualidade de oscilação entre orientação para perda e orientação para a restauração também pode auxiliar num diagnóstico mais acertado.

Para Stroebe e Schut (2001), no entanto, deve-se reconhecer que estratégias típicas do enfrentamento orientado à perda tendem a ser predominantes nos primeiros meses subsequentes à morte, sendo que, após esse período, irão gradativamente - a partir do 
percurso de uma trajetória singular - ceder espaço a estratégias típicas do enfrentamento orientado à restauração, como ressaltou Delalibera (2010). O enfrentamento orientado à perda, contudo, não deixa de ter relevância com o passar do tempo, uma vez que contribuirá para a manutenção simbólica da relação com o ente querido (Mazorra, 2009).

Stroebe e Schut (2001) também salientam que a forma como se desenvolverá a oscilação de cada indivíduo será peculiar porque sofrerá, inevitavelmente, influências do meio em que este se encontra inserido. Cada enlutado, portanto, deve ser entendido como um ser em relação social, imerso num contexto histórico-cultural. Dessa forma, as questões intrapessoais do luto podem ser devidamente contempladas, as quais, como já mencionado, vêm sendo cada vez mais valorizadas por pesquisas recentes dedicadas ao assunto. A propósito, o entendimento pormenorizado dessas questões se apresenta como um desafio, já que não se sabe ao certo como a oscilação pode atingir um nível ótimo de funcionamento (Carr, 2010).

\subsubsection{A noção de luto antecipatório}

O luto antecipatório, como dito na introdução foi identificado em 1944 por Lindemann. Em seu pioneiro artigo Symptomatology and management of acute grief, o autor pode apresentar a correlação entre uma série de sintomas apresentados por um grupo de mulheres cujos cônjuges haviam partido para combates de guerra. Para Lindemann, a ameaça da morte alavancou um processo de sofrimento e adaptação peculiar. Apesar de receber críticas, o pesquisador lançou luz sobre um fenômeno ainda não evidente. A partir daí inúmeras pesquisas foram desenvolvidas na tentativa de aprimorar a compreensão do que seria o luto antecipatório, relacionando-o com outras perdas (Rando, 1986).

Não existe consenso no que diz respeito ao tema, a noção de luto antecipatório é cercada de controvérsias, não havendo concordância acerca de seus conceitos, características, expressão, benefícios etc. Os pesquisadores têm conclusões diversas e compreendem o fenômeno de inúmeras maneiras. M. J. Kovács (comunicação pessoal, 29 de setembro de 2016) e, na mesma direção, Parkes (1998) afirmam que, por se tratar de um processo, o luto não deveria ser dividido em antes ou depois da morte, no entanto, a divisão entre "luto antecipatório" e "luto pós-óbito" pode ser favorável com o intuito de se aprofundar na pesquisa de suas especificidades.

A literatura especializada indica que se preparar para os desafios práticos e subjetivos advindos da experiência do luto é importante. Luto antecipatório e pós-óbito 
são complementares e precisam ser olhados como tal. De acordo com Pine (1986), seria mais realista considerar o sofrimento como um fenômeno que ocorre ao longo de um continuum, já que a pessoa enlutada não se liberta do luto depois de um tempo específico ter decorrido, ela o vivencia processualmente.

De acordo com M. J. Kovács (comunicação pessoal, 24 de junho de 2020) e Flach et al (2012), o luto antecipatório deve ser um luto autorizado, ou seja, precisa ser reconhecido pelos profissionais, pela família e sociedade. Este processo que pode ser vivenciado tanto pelo paciente quanto pelo entorno (familiares, amigos, vizinhos etc.). Sob o ponto de vista do paciente, o luto antecipatório pode ser vivenciado a partir da noção da perda de si e de sua identidade, sendo um momento de revisão da própria história de vida. A forma como a pessoa irá lidar com a presença de uma doença grave em si recebe a influência das características da personalidade, história de vida, fase do desenvolvimento em que a pessoa se encontra, contexto em que a doença foi diagnosticada e desenvolvida (inclusive situação econômica, de moradia), as interações familiares e a rede de apoio social.

Do ponto de vista do entorno, o luto antecipatório tem como característica a vivência de ambivalências nas quais coabitam o desejo de proximidade íntima e distanciamento do ente adoecido e, também, a dificuldade de estar frente a frente com a própria finitude, e com o sofrimento do outro. Franco (2018) aponta para esta situação, considerando que uma série de perdas antecedem a perda por morte propriamente dita, e que a dinâmica familiar e individual irá interferir profundamente no modo de enfrentamento:

... Após uma perda - que pode ter começado com a perda da ilusão de que nada de ruim aconteceria - o sistema familiar tende a conservar seu modo de operar prévio. Quando uma família não tem o hábito de se ajudar mutuamente, não o fará numa situação em que isso seria muito necessário. Por outro lado, as regras familiares podem mudar ou ser revistas. Um luto familiar pode levar a uma negociação sobre novas regras e a reinterpretação de regras existentes. As regras que regem uma família enlutada podem ser mais ou menos difíceis de serem vividas porque cada membro do sistema familiar, incluindo a pessoa perdida, tem um papel, uma visão e necessidades diferentes. $O$ processo de luto será vivido de forma diferente por cada membro. Cada membro tem um relacionamento com a pessoa doente ou com o falecido; possui distintas redes de suporte fora da família; experiência diferentes sentimentos. A família pode tolerar ou não a expressão dessas diferenças. Os novos papéis que se impõem, sobretudo quanto à necessidade de cuidados, demandam da família a busca de soluções para enfrentar uma situação não desejada por todos e que pode denunciar seus conflitos prévios, como apontam Gouveia-Paulino e Franco5 [sic]. Assim, a atenção a todas essas situações pode atuar como prevenção para luto complicado na família. (Franco, 2018, pp. 230-231) 
Segundo Fonseca e Fonseca (2002), existem várias linhas teóricas que podem ser utilizadas para a compreensão e o atendimento em luto antecipatório. No presente trabalho, seguirei os pensadores que entendem que lidar com este processo de luto pode tornar o luto pós-morte mais ameno, por permitir que conteúdos cognitivos e emocionais sejam tratados, reduzindo assim a intensidade da dor psicológica e tempo do luto posterior, justamente por permitir que questões internas sejam olhadas e na medida do possível trabalhadas.

De modo geral, o luto antecipatório ocorre em antecipação frente a uma "morte anunciada" e, conforme os autores supracitados, se afigura como etapa do enlutamento enquanto processo que, para ser levado a bom termo, deverá ter continuidade após a morte da pessoa querida.

O aporte teórico de Rando (1986), Pine (1986), Lebow (1976), Kovács (1992, 2003a; 2008); Kübler-Ross (1996; 1998a; 1998b); Rolland (1998), Worden (1998), Fonseca (2004; 2002) e Gonzaga $(2012$, 2015) serão utilizados para sustentar este constructo, que consideram que o luto antecipatório faz parte de um luto global e que auxilia no desenvolvimento dos processos pós-óbito, mas tendo em mente que nem todos os envolvidos em uma morte anunciada estão em luto antecipatório.

Rando (1986) afirma que a experiência de uma doença grave avançada, momento em que o luto antecipatório acontece, tem uma profunda influência no luto pós-óbito. Aspectos como o tempo e as relações podem ser tratadas neste momento. Sendo assim, o luto pós-óbito pode ser realizado relativamente melhor do que se não houvesse esse processo.

Para Rando (1986), o luto antecipatório e o luto pós-óbito ou convencional são marcadamente diferentes por diversas razões. No luto antecipatório existe o fato de que há um fim definido, e o processo é cessado com o falecimento do ente querido. Contudo, o sofrimento pela perda continua. Para a autora, o luto antecipatório seria um conjunto de processos vivenciados, tanto pelo paciente quanto pelos familiares, no tempo transcorrido entre o diagnóstico e a morte propriamente dita.

De acordo com Worden (1998) e Gonzaga (2012, 2015) existem, não raro, dificuldades em lidar com a morte anunciada, o que indica um processo de luto antecipatório pouco consistente. Nas palavras de Franco temos que:

O conceito de luto antecipatório, como descrito por Rando, foi por um tempo mal interpretado, por ter sido entendido como uma despedida prévia da pessoa que estivesse com a perspectiva de morte próxima. Com o fortalecimento dos cuidados paliativos, o luto antecipatório tornou-se evidentemente parte integrante dessa modalidade de 
cuidados, requerendo, portanto, conhecimentos técnicos para que possibilite um atendimento com qualidade para os envolvidos. (Franco, 2018, p. 228)

Ocorre que não discutir a iminência da morte, seu impacto na família e as providências a serem tomadas quando ela vier a acontecer pode dar a sensação de que ela não irá ocorrer. A negação é uma reação que permite amenizar o impacto causado pela morte que está à espreita, perturbando visceralmente os que estão ao redor do moribundo (Kübler-Ross, 1998b). Não entrar em contato com as questões da morte pode funcionar como um pensamento mágico, isolando e protegendo a psique do indivíduo. Mesmo tendo a oportunidade de vivenciar o luto antecipatório, a família não necessariamente se organizará para a morte (Fonseca \& Fonseca, 2002; Gonzaga, 2012).

De acordo com Parkes (1998), uma morte esperada permite que a pessoa, já enlutada, tenha a oportunidade de se preparar melhor em termos psicológicos, se comparada a uma pessoa que vivencia a morte inesperada de um ente querido. Neste período é necessário um ensaio de ajustamento ao ambiente/atividades cumpridas pelo ente adoecido. Aspectos práticos como definir com quem as crianças ficarão, onde morar, como será feita a limpeza da casa, ou mesmo, como realizar os serviços de banco tem função importante no processo como um todo (Rando, 2000; Stroebe et al., 2001) . Acontece que, por se tratar de um tema tabu, esses pensamentos podem ser considerados socialmente repulsivos. No entanto, o profissional que acompanha o processo deve auxiliar na comunicação entre os envolvidos, estando atento a comportamentos que revelam o pensamento mágico de que tudo será resolvido sozinho (Gonzaga, 2012; Worden, 1998).

Para Worden (1998), o luto antecipatório ocorre anteriormente à morte propriamente dita, e seus sintomas são similares aos de um luto normal pós-óbito. Este pode ser impactado por fatores inter e intrapsíquicos. De acordo com o autor, o indivíduo pode expressar seu luto individual e também viver um luto familiar, social. Rolland (1990) também segue na mesma direção. Para o autor, o processo de perda antecipada é marcado por uma gama de sentimentos intrapsíquicos e interpsíquicos, ou interacionais, que irão acompanhar todo o processo de adoecimento até o acometimento da morte em si. O autor lista os sentimentos e pondera que há uma flutuação entre eles: ansiedade devido à separação, solidão existencial, negação, decepção, raiva, ressentimento, culpa, exaustão e desespero.

Um dos estudos de Rando (1983; 1986) foi dedicado ao processo de luto antecipatório de pais com crianças que desenvolveram câncer. Tal pesquisa pode 
contribuir na compreensão de que a duração do adoecimento estaria relacionada a uma boa ou má preparação para a morte. Em linhas gerais, a autora indicou que, quando o tempo entre o adoecimento e a morte era abreviado (menos de seis meses) ou estendido (mais de dezoito meses), os pais apresentaram-se menos preparados para a morte, com ajustamentos pobres no luto pós-óbito. Nestes casos, os pais apresentavam altos escores de raiva, hostilidade e características de luto complicado. Em contrapartida, a pesquisa apontou que aqueles que vivenciaram o adoecimento no período entre seis a dezoito meses apresentaram-se mais preparados para a hora da morte, tendo ajustamentos mais satisfatórios.

De acordo com a autora, algumas linhas teóricas divergentes sugerem que o sofrimento antecipado é aumentado com proximidade da morte. No entanto, sua experiência clínica mostra que:

... há uma influência pelas defesas do ego e que, provavelmente, o equilíbrio entre a negação (que presumivelmente poderia impedir o trabalho de luto antecipado) e a aceitação (que poderia facilitar o processo) explica porque o sofrimento antecipado não aumenta necessariamente à medida que a perda se aproxima. (Rando, 1986, p. 10, tradução minha)

Em oposição a Rando, Worden (1998) observa que um sentimento presente é a ansiedade de separação, que aumenta conforme a morte se aproxima e porque rebate na percepção da própria finitude. $\mathrm{O}$ fato de se saber que a morte ocorrerá possibilita que os envolvidos iniciem o que ele chama de tarefas do luto. No entanto, certos problemas também podem ocorrer nesses casos, visto que o prolongamento da morte pode gerar ressentimentos e culpa. Nesse processo, o enlutado toma consciência da perda que está anunciada, sendo que negação e aceitação são polaridades visitadas durante tal período. Outro sentimento observado pelo autor é a ambivalência entre o desejo de morte e a culpa.

De acordo com Pine (1986), há nesta fase o risco de que aconteça um distanciamento emocional do ente adoecido, principalmente quando o tempo no processo de morrência é longo. Já Rando (1986) afirma que a elaboração do luto antecipatório não se refere ao desligamento de vínculo, ou mesmo ao movimento de afastar-se da pessoa amada que está adoecida. Muito pelo contrário, é nesse momento em que o familiar vive em uma situação dificílima por estar entre a preparação para a perda em si e a experiência de dedicar atenção, carinho, amor ao ente que está partindo.

Para Pine (1986), é necessário compreender as muitas dimensões deste processo que pode ser repleto de complexidades e pode atingir as esferas psicológicas, sociais e culturais dos envolvidos. Lebow (1976), na mesma direção, compreende o luto 
antecipatório como um conjunto de reações vivenciados por todos os envolvidos (paciente e familiares) relacionadas à esfera cognitiva, afetiva, social e cultural. Sendo assim, o luto antecipatório é um sofrimento verdadeiro, legítimo e que é experimentado a partir da consciência da morte (Pine, 1986).

Rolland (1995) é categórico ao afirmar que a ameaça à vida gera tanto nos pacientes quanto nos familiares sentimentos de temor pela finitude e pela solidão. Neste processo de luto antecipatório, as famílias, em geral vivenciam tristeza e iniciam a adaptação à perda. É comum que os familiares desejem intimidade e, ao mesmo tempo, sejam acometidos por um impulso que os afasta emocionalmente do ente querido, reafirmando o que foi dito anteriormente.

Por fim, para encerrar o item sobre a noção do que é luto antecipatório, temos que este é um processo que dá início com a consciência de uma morte anunciada e se apresenta como um luto real, inserido num processo de luto global. Caracteriza-se como um conjunto complexo e multidimensional, e que está relacionado a uma perda presente, mas também a perdas passadas e futuras. Entrar em contato com este processo deve ser apoiado e estimulado a fim de diminuir a solidão, a interdição de processos intrapsíquicos e interpsíquicos, de falta de comunicação, tornando o processo digno, possibilitando a realização de despedidas, o encerramento de assuntos inacabados, possibilitando que os familiares possam, na medida do possível, investir emocionalmente e cognitivamente nesse processo de despedida e cuidados (Fonseca, 2004; Fonseca \& Fonseca, 2002; Kovács, 1992; Lebow, 1976; Pine, 1986; Rando, 1986)

\subsubsection{Reflexões sobre a "morte domada", "morte interdita" e "morte anunciada" e o novo contexto de doenças crônico-degenerativas}

Como mencionado anteriormente, o processo de luto antecipatório pode ser iniciado por diversos motivos. Contudo, no presente trabalho, estará relacionado ao pesar antecipatório de familiares que foram acometidas pelo adoecimento originado por uma doença crônico-degenerativa não oncológica, como Alzeimer, Parkinson, Esclerose Lateral Amiotrófica, Esclerose Múltipla, Acidente Vascular Cerebral, dentre outras que apresentam sequelas neurológicas e neuromusculares. Este recorte se dá por uma simples razão: os pesquisadores têm se dedicado bastante à compreensão do luto e do respectivo manejo junto a pacientes e familiares no contexto das doenças oncológicas, ao passo que 
um reduzido número de pesquisas tem sido dedicado às doenças supracitadas (Flach et al., 2012; Gonzaga, 2012).

Para tratar do luto antecipatório no contexto das doenças crônico-degenerativas, é necessário abordar algumas mudanças fundamentais que foram ocorrendo ao longo da História da Humanidade, já que estas imprimiram transformações na construção de sentidos sobre o adoecimento e a morte. Para tratar dessas questões utilizarei três parâmetros importantes encontrados na literatura especializada: a "morte domada", a "morte interdita" e a "morte anunciada" 2 .

Para Ariès (1981), durante a maior parte da Antiguidade valorizou-se, no mundo ocidental, a chamada "morte domada". O homem naquela época entendia que, idealmente, deveria tomar conhecimento, por meio de uma espécie de convicção íntima, da aproximação de seu fim. A morte era ritualizada em cerimônias públicas, até porque era considerada uma situação natural da própria vida. Lideradas pelo próprio moribundo, tais cerimônias contavam com a participação de toda sua comunidade e serviam como preparativo para o futuro encontro com Deus. A morte súbita, em contrapartida, era temida e considerada um castigo divino, posto que sinalizava impureza da alma e do corpo.

Já no século XX alguns grandes acontecimentos históricos, dentre os quais se destacam as Guerras Mundiais, inauguraram uma era de incertezas, na qual, conforme Rottenstein (2005), a probabilidade de morte em massa tornara-se realidade. Dessa forma, a humanidade, abalada por seu próprio poder de destruição, começou a sentir-se fragmentada e perdida. A morte passou a provocar ojeriza e as manifestações de luto, consequentemente, foram modificadas. Como bem observou Ariès, (1981), passou-se a valorizar a chamada "morte interdita", que deveria ocorrer fora do convívio público e sem o conhecimento prévio do moribundo.

Kovács (1992) salienta que a "morte interdita" representa o extremo oposto da "morte domada", considerada ideal na Antiguidade. Porém, o advento da morte interdita transformou até mesmo o local do óbito, que deixou de ser a residência familiar e passou

\footnotetext{
${ }^{2}$ M. J. Kovás (comunicação pessoal, dia 26 de março de 2021) ressalta que durante toda a história da humanidade sempre estiveram presentes as referidas mentalidades diante da morte (interdita, anunciada, domada etc) sendo vivenciadas concomitantes no dia-a-dia. É importante apontar aqui que existem outras mentalidades e outros conceitos que não foram tratados nesta pesquisa, como, por exemplo, um conceito denominado por Kovács como "morte escancarada" (Kovács, 2003b). De acordo com a autora este conceito é pertinente ao contexto atual e está relacionado a invasão constante e intrusiva do tema morte na rotina das pessoas, seja por via midiática (telejornais, novelas, documentários etc), pelo contato com a violência abrupta no cotidiano dificultando a elaboração do luto.
} 
a ser o hospital. Essa transformação, em parte, ocorreu também em função de uma série de avanços científicos que tornaram as práticas de saúde essencialmente tecnocêntricas e, como salienta Kübler-Ross (1998a), humanamente empobrecidas e menos ligadas ao indivíduo. Os limites da vida e da morte se modificaram, assim como a concepção que se tinha sobre eles (Menezes, 2004). Neste cenário, o desafio que se apresentava aos profissionais de saúde seria o de evitar a morte a todo custo.

Nesse sentido, os avanços tecnológicos das últimas décadas contribuíram para a transformação do perfil epidemiológico da população, na medida em que, promoveram um aumento da expectativa média de vida tanto nos países desenvolvidos quanto nos países em desenvolvimento (Barreto \& Carmo, 1995). A transição demográfica, por sua vez, levou a uma evolução progressiva de altas taxas de mortalidade por doenças infecciosas para altas taxas de mortalidade por doenças crônico-degenerativas, tratandose de um cenário irreversível (Brasil, 1999).

A morte deixou de ser vista como um fenômeno natural e tem sido considerada essencialmente, no século XXI, como um fracasso do homem em manter a vida a despeito de todo seu conhecimento científico traduzido em equipamentos hospitalares extremamente sofisticados. É nesse sentido que Kovács (2003a) defende que a expressão do luto, na atualidade, muitas vezes é considerada tão indecente quanto à própria morte. Afinal, valoriza-se uma postura discreta e serena perante o óbito de uma pessoa querida. Manifestações de dor pela perda, em contrapartida, são comumente repudiadas. A referida autora propõe, inclusive, que a "morte interdita" transformou o luto em uma doença. Sendo assim, a morte, a partir do século XX deveria acontecer no hospital por ser este o local onde poderiam ser oferecidos todos os recursos necessários para combatê-la, e também o local aonde se deveria ir para morrer (Ariès, 1981). Neste cenário, diferentemente do que ocorria na morte domada:

O homem não sente mais a morte chegar, desconhece os seus sinais, que lhe são camuflados. O paciente perdeu o seu lugar social. O doente foi privado de suas vontades e de sua consciência, não é consultado em suas necessidades mais básicas [...]. A morte tornou-se, em muitos casos um ato solitário, mecânico e doloroso. E a medicina representante do século XX preocupa-se mais com o desenvolvimento tecnológico do que com o bem-estar do outro. (Bastos, 1983, citado por Kovács, 1992, pp. 191-192)

Com as mudanças no perfil epidemiológico, há como dito anteriormente, o aumento das doenças crônico-degenerativas. O que faz, por sua vez, surgir no século XXI um novo contexto: a "morte anunciada". Trata-se da morte previamente identificável por meio da presença de um conjunto de sinais e sintomas, a qual tipicamente acomete portadores de doenças crônico-degenerativas e ocorre na presença da família (Fonseca \& 
Fonseca, 2002). Nesse quadro, a "morte interdita" torna-se impraticável porque não é possível ignorá-la e não ser afetado por ela. Não é possível não perceber a piora dos sintomas e não ver a morte se aproximar diante dos próprios olhos. Ocorre que a presença de um ente gravemente adoecido por uma doença que degenera paulatinamente, a questão da morte é trazida novamente para o interior das casas, atravessando a intimidade das relações familiares (Gonzaga, 2012). De acordo com Fonseca (2004):

O diagnóstico de uma doença crônica gera uma crise para a qual a família não está preparada, principalmente com relação às mudanças físicas, psicológicas e sociais assim como para os períodos alternados de estabilidade e crise, e também as incertezas quanto ao funcionamento futuro decorrente. Uma doença grave exige novos modos de enfrentamento, mudanças de postura tanto do paciente como de sua família e amigos, que sofrem múltiplas perdas, períodos longos de adaptação e interações frequentes com o sistema de saúde. Como unidade de cuidados, a família necessita mobilizar-se diante da iminência da perda de um de seus membros de modo a preparar-se para as mudanças decorrentes de uma situação como esta. O sofrimento é uma reação universal à perda de uma figura de vínculo, mesmo que as manifestações desse sofrimento sejam culturalmente determinadas. (Fonseca, 2004, p. 20)

A presença da "morte anunciada" tem gerado transformações, mas a vivência da "morte interdita" se mostra ainda muito arraigada. A prova disso é um profundo desconforto dos familiares quando a morte, mesmo sendo esperada por anos, acontece no domicílio. Em seu estudo, Gonzaga (2012) averiguou que, mesmo os pacientes tendo sido cuidados em domicílio por uma equipe multiprofissional por longos períodos, a opção de morrer no hospital foi escolhida pela maioria das participantes de sua pesquisa. Estes dados podem demonstrar que ainda estamos atravessando uma longa fronteira, onde se mesclam aspectos da morte interdita e da morte anunciada, tanto para a família, quanto para a equipe de saúde que acompanhava.

Para Rolland (1995), o tipo de doença, suas distinções, consequências e sequelas influenciam fortemente no cuidado e na saúde mental dos familiares. De acordo com Franco (2018), o contato com as doenças crônicas pode provocar sentimento de impotência devido à falta de informação, e esta condição talvez seja o que traga mais angústia ao processo saúde/doença. Tal contexto pode interferir na qualidade do processo de luto antecipatório. Quando a morte é anunciada por um diagnóstico de doença grave, a rotina do familiar é transformada radicalmente e ele é obrigado a incluir tarefas totalmente novas e desgastantes em seu cotidiano, para as quais geralmente não possui habilidades específicas ou treinamento prévio.

De acordo com Kovács (2014), no contexto da morte anunciada, tanto pacientes quanto familiares devem ser esclarecidos sobre a doença e os tratamentos para que possam, desse modo, evitar processos distanásicos, tão característicos do contexto da 
morte interdita. Neste contexto é fundamental retomar aspectos da morte domada, para que o luto antecipatório seja vivido de uma maneira respeitosa e menos violenta possível. Para terminar, a autora orienta:

Para se ter dignidade é fundamental: ter conhecimento da aproximação da morte; controle; intimidade e privacidade; conforto para sintomas incapacitantes; escolha do local da morte; ter informação, esclarecimento, apoio emocional e espiritual; acesso a cuidados paliativos; pessoas com quem compartilhar; acesso às DAV [diretivas antecipadas de vontade], poder decisório e poder se despedir; partir sem impedimentos. (Kovács, 2014, p. 101)

Sendo assim, é necessário inserir sempre na compreensão de um caso de luto antecipatório as peculiaridades que trazem o tipo de doença crônico-degenerativa que o ente querido desenvolveu. A partir deste contexto específico, e da análise da situação cultural, histórica e social, é que o profissional poderá realizar uma análise mais acertada do contexto, e poder ser útil em sua ação. O processo de luto antecipatório está diretamente ligado ao tipo de doença que o desencadeia, visto que existe uma enorme diferença entre o impacto gerado por uma doença aguda, ou mesmo entre alguns tipos de doenças crônicas. De certa forma, as doenças crônicas que degeneram a saúde física do indivíduo se apresentam como um desafio recente, que ainda carece de estudos e investigação.

\subsubsection{Atendimento em domicílio: histórico, portaria, implicações do trabalho em equipe e peculiaridades do trabalho psicológico neste contexto}

O luto gera inúmeros sentimentos que podem demandar a intervenção do profissional de psicologia. Esta intervenção, em geral, ocorre em consultórios, ambulatórios, e hospitais, mas pode ocorrer também no domicílio. De acordo com Laham (2004), o atendimento domiciliar tem raízes antigas, como averiguamos em citações encontradas em documentos seculares, como na Bíblia.

Até a Idade Média, na Europa, em geral o tratamento médico era dispensado no domicílio, ao passo que os hospitais se comportavam como morredouros que atendiam essencialmente pessoas miseráveis e portadores de doenças contagiosas. Neste contexto, os cuidados eram dispensados por religiosos e voluntários. Já no século XIX, de acordo com a autora, passaram a existir as equipes de enfermeiras visitadoras, ligadas a movimentos de filantropia que tinham o objetivo de trabalhar a prevenção de doenças e outras demandas da saúde pública. Já no século seguinte, os médicos passaram a realizar este tipo de visita, mas com certas limitações no que se refere à tecnologia e aos 
tratamentos oferecidos. A esta altura os hospitais já estavam consolidados como referência em processos de tratamento e cura.

Tal modalidade, apesar de ter sofrido inúmeras influências, manteve sua existência. Contudo, como alternativa à superlotação hospitalar, deu início o resgate do modelo de atendimento domiciliar: nos EUA, em 1947; na França, em 1951; e no Brasil, em 1968 (Laham, 2004). Em terras brasileiras, este tipo de assistência teve sua origem a partir da saúde pública, e mais especificamente devido a necessidades sanitaristas para o controle de epidemias (Oguisso, 1999, citado por Fonseca, 2004, p. 41). Ao longo do tempo foram surgindo outros trabalhos, iniciativas provenientes tanto da iniciativa pública quanto da privada.

A estrutura do programa de atenção domiciliar é diversa, podendo variar em se tratando do próprio funcionamento, mas também dos tipos de profissionais que compõem a equipe e dos objetivos propostos. No estudo de Gonzaga (2012), por exemplo, a equipe multidisciplinar a qual pertenciam tinha como característica ser multiprofissional, sendo composta por: médicos clínicos e especialistas, auxiliares de enfermagem, enfermeiraspadrão, fisioterapeutas, psicólogos, farmacêutica, dentista, fonoaudióloga, assistente social, nutricionista, além de secretárias e motoristas que eram cedidos pelo Hospital de Clínicas da Universidade pública ao qual estava lotado. Esta equipe atendia cerca de 300 famílias e tinha como objetivo a assistência de pacientes com sequelas neurológicas/neuromusculares e, também, pacientes com doenças pulmonares graves que estivessem em tratamento utilizando oxigenoterapia domiciliar. Contudo, estas características são variáveis entre os programas conforme já mencionado.

As equipes em geral são multiprofissionais porque a demanda é complexa. Um trabalho gerido por uma equipe com esta característica agrega imensos benefícios ao processo de cuidado, já que o paciente será assistido por profissionais que utilizam diversos pontos de vista. Morin (2000) aponta que a fragmentação do saber é inadequada, sendo uma desvantagem à avaliação de uma realidade que demande um olhar transversal. Segundo o autor, o trabalho de uma equipe que produz comunicação horizontal permite que as fronteiras das especialidades sejam atravessadas, melhorando a produção de conhecimento e o resultado da ação.

De acordo com Galheigo (1999), é necessário que se reconheça a complexidade do problema, isto é, que se utilize o pensamento complexo que admite a incerteza, reconhece a impossibilidade de reduzir o problema a partes simples, assim como atribui coerência neste mundo multidimensional e multirreferencial da saúde. Além disso, 
práticas fragmentadas geram alienação e desmotivação no profissional de saúde, pois, quando o seu trabalho fica restrito a uma pequena parcela do processo terapêutico, ele não consegue ter uma dimensão do resultado global do estado de saúde do seu paciente (Brasil, 2004). Para garantir tal processo, é importante ser constituído espaço para a realização de reuniões de equipe para discussão de casos atendidos pela equipe, questões do próprio funcionamento do serviço e também para que os profissionais compartilhem sua ação, seus objetivos, aporte teórico e alinhamento da linguagem profissional (Gonzaga, 2012; Junior, 2008).

Contudo o trabalho em equipe não é um exercício simples, e é de certa forma pouco tratado durante a formação profissional nos cursos da área da saúde. Muitas vezes, a presença do psicólogo pode causar inquietação, expectativas e certa confusão. Junior (2008), em seus estudos, constatou que muitas vezes a equipe frente à possibilidade de ter um psicólogo na rotina de trabalho espera ser cuidada pelo profissional. Tal demanda é real, já que o trabalho em saúde é extremamente desafiante, causando muitas vezes estresse crônico (por exemplo, Síndrome de Burnout). Frente a tal reação, no entanto, o psicólogo deve ponderar sempre que o seu cliente não pode ser a equipe, já que a ela pertence.

Orquestrar os espaços, os tempos e as funções de cada profissão dentro de um trabalho multiprofissional é, como dito anteriormente, um esforço necessário. Os serviços de atendimento domiciliar públicos passaram por muitas reflexões e adequações. Em 2016, em última instância, o Sistema Único de Saúde (SUS) o redefiniu oficialmente por meio da Portaria No 825, de 25 de abril de 2016 (Saúde, 2016), atualizando seu modo de funcionamento. Como já mencionado, mesmo que brevemente, na introdução, no corpo do texto da referida portaria são definidos os conceitos e orientações sobre a atenção domiciliar e seus graus de complexidade, além de objetivos, diretrizes de ação, indicação e organização do serviço de atenção, a composição das equipes e o seu funcionamento, os requisitos para habilitação, orientação para criação ou ampliação nos municípios, financiamento e outros.

Este documento, em linhas gerais, prevê que é de responsabilidade do SUS o cuidado ao usuário, familiar e cuidador, respeitando-se as atribuições constitucionais, os princípios e as diretrizes que garantem a universalidade de acesso, a equidade e a integralidade da atenção. A Atenção Domiciliar (AD) é caracterizada por um espectro amplo de atuação, indo da promoção da saúde à paliação de usuários que não conseguem ser deslocados para unidades de saúde. O Serviço de Atenção Domiciliar (SAD) é um dos 
setores da Rede de Atenção à Saúde, e tem o objetivo de complementar os cuidados tanto na Atenção Primária (Atenção Básica) até a Alta Complexidade (Atenção Terciária). Sendo assim, este tipo de serviço tem coberturas diversas, atendendo às complexidades necessárias, sendo que a $\mathrm{AD}$ está ligada aos casos que têm menos complexidade e o SAD aos que tem mais.

De acordo com tal Portaria, o objetivo do SAD é a redução da demanda por atendimento hospitalar, diminuição do tempo de internação, a humanização do tratamento com vistas a assegurar a autonomia do usuário, bem como privilegiar a desinstitucionalização acrescida do uso mais adequado dos recursos (financeiros e de estrutura) da rede de saúde. Este serviço é disponível para todos os municípios que possuam 20.000 habitantes ou mais.

A presença do profissional de psicologia nas equipes de atendimento domiciliar ainda é facultativa. Tal fato pode empobrecer o trabalho em saúde, já que a dimensão psicológica é parte importante do conceito de saúde integral e de seu bom desenvolvimento. Contudo, tal modalidade já existe há muitos anos, apesar de ainda ser pouco tratada na literatura especializada em Psicologia (Fonseca, 2004; Lahan, 2004; Gonzaga, 2012).

Com o intuito de orientar a prática do psicólogo neste contexto, o Conselho Regional de Psicologia de São Paulo (CRP-SP, 2017) produziu uma série de reflexões sobre o assunto. Segundo o órgão, o modelo de atendimento domiciliar é pouco conhecido pela categoria e está em expansão tanto nos setores públicos quanto privados. Este modelo é dedicado à população que possui patologias que dificultem ou impeçam a locomoção destes para receber tratamento em unidades de saúde.

A psicologia domiciliar é diferente da clínica tradicional e exige uma leitura aguçada do contexto social, cultural e uma interação distinta das intervenções clássicas. Algumas peculiaridades são: demanda de atendimento (espontânea, da família ou solicitação da equipe); especificidades do setting terapêutico (local, número de atendimentos, sigilo, aproximação social) - no domicílio, o controle do setting se dá mais pelas condições físicas da moradia e pelo próprio cliente que pelo profissional, que por outro lado deve se adequar e criar manejos para diferentes situações; campo de atuação existe um sistema que deve ser considerado no atendimento, composto pelo próprio cliente, seus familiares, o cuidador principal e, também, a própria equipe; e a possibilidade de atendimento compartilhado e simultâneo ao de outros profissionais. 
A demanda do atendimento pode ocorrer por diversas origens: a partir do próprio paciente, da família e/ou pela equipe multiprofissional. A origem da demanda deve ser levada em consideração para a avaliação da real necessidade e para garantir o direito de livre escolha e autonomia da pessoa que foi colocada em foco para ser atendida. Outra possibilidade é que, em se tratando de uma equipe multiprofissional, às vezes um paciente ou familiar escolhe um dos membros da equipe, não necessariamente o psicólogo, para contar algo que está lhe incomodando. Nestes casos, é importante que a escolha seja legitimada e o profissional escolhido receba suporte para a realização do acolhimento.

Com relação às especificidades do setting terapêutico, é preciso refletir sobre o local, número de atendimentos, sigilo e aproximação social. Muitas vezes a casa não é composta por muitos cômodos e, assim, outros espaços do entorno poderão ser utilizados como a praça, a rua, o fundo do quintal, ou outros possíveis (Gonzaga, 2012; Fonseca, 2004; Laham, 2004). Aqui deve haver uma atenção especial à questão do sigilo, que necessita ser tratado junto ao familiar/paciente atendido. A quantidade de atendimentos, bem como a frequência serão definidos a partir do diagnóstico situacional realizado nas primeiras visitas dos/das profissionais da psicologia.

Outro ponto que gera muitas vezes embaraços nos profissionais de saúde é com relação à proximidade social. Ao entrar na residência, está imbricado o contexto cultural de determinada família, sendo que existe a possibilidade de a família confundir a presença profissional. É preciso que os/as profissionais estejam bem vigilantes para não fugir de seus objetivos. Flexibilidade é um ingrediente imprescindível, pois um atendimento substancial pode começar com assuntos cotidianos e avançar para aspectos mais profundos da psique.

O toque corporal também é outro aspecto marcante em nossa cultura, ao receber visitas em casa, atendemos a porta com entusiasmo e ações calorosas. No atendimento domiciliar pode acontecer reação semelhante por parte dos familiares, e o profissional, treinado a ter distância corporal do paciente, pode sentir-se embaraçado, constrangido. Esta situação é bastante polêmica e mereceria em outro momento reflexões mais aprofundadas, contudo, acho válido pensar que uma boa dose de traquejo e jogo de cintura poderá auxiliar, observando sempre o que é importante, valoroso àquela família, oferecendo, se necessário, um abraço sincero que poderá acolher e ajudar na construção de um bom rapport.

O controle do setting se dá mais pela família do que pelo profissional. A psicóloga ou psicólogo deve estar atento aos limites dados no atendimento, e garantir que sua 
presença não seja sentida como invasiva (Laham, 2004). Para Laham, entrar na residência do paciente é uma oportunidade que permite o contato com a realidade vivida pela família. A partir desta possibilidade, podemos observar a dinâmica da família de uma forma que não seria possível se este paciente estivesse relatando sua rotina durante um atendimento realizado em uma instituição de saúde. Contudo o fato de entrar em contato com informações extras, que muitas vezes o usuário não escolheu tratar, exige uma postura ética que autorize o psicólogo a tratar de tais pontos (CRP-SP, 2017).

Com relação ao campo de atuação, temos um amplo espectro. O tratamento terapêutico poderá contemplar o atendimento individual e/ou o sistema familiar. É imprescindível que o psicólogo tenha ou busque treinamento não somente em psicoterapia individual, pois muitas vezes os avanços no processo psíquico só são alcançados quando a família é atendida como um sistema. Em alguns casos, o trabalho envolve a família como um todo ou apenas o responsável pelos cuidados prescritos ao paciente. Contudo nem sempre o psicólogo tem preparação para este trabalho, visto ser comum nas instituições de ensino a formação em clínica individual, e não em saúde coletiva e saúde pública. Segundo os estudos de Junior (2008), para os participantes de sua pesquisa (todos psicólogas e psicólogos), houve um estranhamento, uma "sensação de despreparo nos primórdios de suas atuações, pelo desconhecimento das possibilidades de atuação no campo e dúvidas surgidas na experimentação" (Junior, 2008, p. 90). Frente a essa situação, as/os profissionais precisam se manter em aprendizagem constante para se dispor de ferramentas para ações em que "a imprevisibilidade é o padrão" (Junior, 2008, p. 95).

Aqui podemos aproximar a Atenção Domiciliar das propostas da Clínica Ampliada $^{3}$ por uma série de motivos. No entanto, aqui pincelarei apenas alguns aspectos

\footnotetext{
3 "O que é clínica ampliada? A clínica ampliada é uma das diretrizes que a Política Nacional de Humanização propõe para qualificar o modo de se fazer saúde. Ampliar a clínica é aumentar a autonomia do usuário do serviço de saúde, da família e da comunidade. É integrar a equipe de trabalhadores da saúde de diferentes áreas na busca de um cuidado e tratamento de acordo com cada caso, com a criação de vínculo com o usuário. A vulnerabilidade e o risco do indivíduo são considerados e o diagnóstico é feito não só pelo saber dos especialistas clínicos, mas também leva em conta a história de quem está sendo cuidado. Qual o diferencial da clínica ampliada para o usuário? A ampliação da clínica trabalha os danos e os benefícios gerados pelas práticas de saúde, e aposta nas equipes de diferentes especialidades compartilhando a responsabilidade com os usuários e seu entorno. O serviço de saúde pode acolher a queixa do usuário mesmo que a fala pareça não ter relação direta para o diagnóstico e tratamento, pois essa escuta auxilia o próprio usuário a descobrir os motivos de seu adoecimento, por exemplo. Na prática, como a clínica ampliada acontece? Através da escuta, o trabalhador da saúde vai buscar junto ao usuário, os motivos pelos quais ele adoeceu e como se sente com os sintomas, para compreender a doença e se responsabilizar na produção de sua saúde. É importante estar atento para os afetos entre os trabalhadores e usuários buscando a autonomia da pessoa diante do seu tratamento, ao mesmo tempo em que seu caso é tratado de forma única e singular. Um hipertenso, por exemplo, pode e será cuidado de forma diferente de outro
} 
que irão auxiliar na reflexão geral. Em se tratando de um processo de adoecimento crônico-degenerativo, o acompanhamento será longo, exigindo maior necessidade de participação e adesão de todos os atores no projeto terapêutico (Saúde, 2009). Para que a assistência alcance seus objetivos (prevenção, promoção e paliação), é preciso considerar a vulnerabilidade e o risco dos indivíduos envolvidos. Nesse sentido é imprescindível levar em conta não apenas os aspectos biológicos, mas também a história, a subjetividade e o contexto de quem está sendo cuidado. A proposta da clínica ampliada avança na discussão do modelo biomédico, caracterizado pelo ponto de vista reducionista, cartesiano, mecanicista e especializado.

De acordo com o Ministério da Saúde:

Muitos profissionais tendem a considerar tudo o que não diz respeito às doenças como uma demanda "excessiva", algo que violentaria o seu "verdadeiro" papel profissional. A Clínica Ampliada, no entanto, não desvaloriza nenhuma abordagem disciplinar. Ao contrário, busca integrar várias abordagens para possibilitar um manejo eficaz da complexidade do trabalho em saúde, que é necessariamente transdisciplinar e, portanto, multiprofissional. (Saúde, 2009, p.14)

O quadro do adoecimento crônico-degenerativo se mostra como um grande desafio, sendo necessária a ampliação da autonomia do paciente, da família e da comunidade, dando ênfase a subjetividade e a criação de vínculo entre equipe de saúde e usuários. No atendimento domiciliar, a visita pode ser composta por vários profissionais que atendem em conjunto ou separadamente (Gonzaga, 2012; Laham, 2004). Tal dinâmica representa uma forma diversa de atendimento, se comparada ao atendimento ambulatorial, em que, geralmente, um profissional atende o paciente isoladamente.

Como a atenção domiciliar é um modelo novo e sem protocolo de fluxo, cada programa de atendimento domiciliar constrói sua prática de modo particular, fato este que pode ser positivo por permitir a autonomia e a criatividade, mas também pode trazer muitas dificuldades à prática dos profissionais de saúde.

Fonseca (2004) pondera que os profissionais de saúde, incluindo os psicólogos ao saírem do que ele chamou de "locus terapêutico tradicional", precisam adaptar e transformar sua ação.

A primeira e fundamental é aquela que precisa ocorrer com o terapeuta, de modo a the propiciar uma visão diferenciada e ampliada daquela vivida no ambiente de seu consultório. Esta visão abrange desde seu papel como um observador atuante e ativo num locus diferenciado, passando pela concepção que possui sobre a família e terapia familiar, chegando aos limites de sua própria experiência pessoal com assuntos tais como vínculos, perdas e lutos. (Fonseca, 2004, p.21)

hipertenso, já que cada caso é um caso. Se o usuário estiver deprimido, isolado, desempregado, tudo isso interferirá no desenvolvimento da sua doença e precisa ser ouvido pelo profissional de saúde"(Saúde, 2010). 
Pode ser que, em certos momentos, dependendo da demanda, seja importante o uso de respaldo cognitivo. Este recurso será oferecido quando a família apresentar angústia e requerer auxílio para compreender certos temas como, por exemplo, a compreensão do estado físico do paciente e, também, a dificuldade com algum procedimento. Nestes momentos poderemos convidar membros da equipe multiprofissional para acompanhar o atendimento. É comum o uso de esclarecimentos teóricos também na área da psicologia, já que angústia poderá estar relacionada, por exemplo, à compreensão do luto em si. Neste caso, o processo educativo visa à apresentação de um ou mais dos modelos que facilitem à compreensão do processo de luto, e poderá ser oferecido explanações utilizando constructos como o modelo fase do luto (Kübler-Ross e/ou Bowlby), do Modelo do Processo Dual e a compreensão de Jung sobre a morte e o enlutamento.

Vários programas de saúde utilizam sessões de educação, individuais ou grupais, para auxiliar pacientes e familiares no manejo de sintomas e comportamentos de doenças crônicas, além de propiciar a discussão de pontos relevantes à vida (Godoy \& Godoy 2002). Isso também se aplica nos cuidados de pacientes e familiares em luto. A apresentação teórica auxilia muito na compreensão do processo de luto vivenciado pelos familiares que estão com um ente gravemente adoecido (Kübler-Ross, 1998a, 1998b). Este tipo de intervenção contribui para a diminuição da ansiedade e da depressão dos envolvidos, de modo que tem gerado impactos positivos sobre o tratamento e a qualidade de vida (Leite et al., 2008).

Para o trabalho no domicílio, o profissional de psicologia necessita repensar sua ação e o seu olhar a fim de construir esta nova prática. É necessário instrumentalizar cada vez mais os profissionais para que eles tenham condições para cuidar de tal demanda de modo ético e coerente. No mesmo sentido, mostra-se também necessária a realização de novos estudos dedicados a essa temática, não apenas para agregar à literatura acadêmica, mas também para contribuir para o aperfeiçoamento das intervenções dos profissionais da saúde a fim de contribuir para sanar as lacunas desta área de atuação.

\subsubsection{Manejo psicológico em contexto do luto antecipatório: a quem se destina o cuidado?}

No presente subitem tratarei sobre o manejo terapêutico, partindo do princípio de que o atendimento psicológico de indivíduos enlutados no contexto de mortes anunciadas 
pode beneficiar sua saúde mental. Segundo Worden (1998), este processo deve ser estimulado, já que, em geral, as pessoas precisam de certa permissão para realizar tal empreitada. Nesse sentido, pacientes e familiares podem ser encorajados, tomados os devidos cuidados éticos, a entrar em contato com questões ainda não tratadas e expressar os próprios sentimentos, em um setting seguro, antes que a morte aconteça. Este processo, de acordo com o autor, é fundamental, já que questões importantes podem ser tratadas quando ainda existe oportunidade.

O manejo realizado pelo profissional de psicologia pode ser direcionado às demandas do paciente, de familiares e, também, do grupo família/paciente. No primeiro caso, o trabalho com o paciente deve acontecer onde ele estiver, seja no leito de um hospital ou em casa. O sigilo deve ser maximamente respeitado, e o psicólogo deverá ouvir empaticamente as questões colocadas pelo indivíduo, bem como ser ativo, dialógico e flexível (Amorin, 2004; Fiorini, 1981). Segundo Eissler (1979, citado por Kovács 1992, p. 197) o paciente nessas condições requer cuidados diferenciados, pois sofre uma certa regressão. O autor orienta que o psicólogo poderá oferecer além do respaldo verbal, cumprir certas funções do materno (sustentação, apoio, afeto). Nesse sentido, a proximidade física poderá ser mais terapêutica do que o trabalho com conteúdos psíquicos específicos.

Às vezes, o medo de morrer é menos angustiante do que o de se sentir sozinho e abandonado nestes momentos, há o medo da separação e da perda dos apoios de situações conhecidas e prazerosas. Pode ocorrer ansiedade de aniquilamento e alienação, como se fosse uma morte em vida. A ansiedade de aniquilação pode estar ligada a um medo de desintegração, um medo de perder a sanidade, já que as situações familiares são perdidas, e o paciente encontra-se diante do desconhecido. (Weisman 1972, citado por Kovács, 1992, p. 195)

O paciente pode sentir um temor que está mais associado ao medo do que é desconhecido, e da possibilidade de vivenciar a experiência da morte de modo solitário. O psicólogo e/ou a psicóloga deverão trabalhar a informação e a presença de qualidade junto aos envolvidos, já que muito pode ser feito para alívio da dor, da solidão e da qualidade de vida do paciente como um todo (Kovács, 1992; Kübler-Ross, 1996, 1998b; Saunders, 1990).

Além disso, os profissionais podem ajudar na compreensão e na expressão das representações do paciente sobre seu processo, bem como "traduzir" o paciente para a equipe de saúde, informando sobre sua psicodinâmica facilitando a interação equipe/paciente (CRP-SP, 2017). Desse modo quando o ser humano é olhado, ouvido, 
legitimado, sente-se apoiado e tem maior tendência a experienciar a morte de um modo mais protegido, podendo se sentir respeitado em sua subjetividade (Kovács, 2008).

Contudo, não é só o paciente o único a sofrer o impacto da morte anunciada. $\mathrm{O}$ grupo familiar é um sistema que pode ser alvo de intervenções no contexto do luto antecipatório. Fonseca (2004) afirma que os profissionais de saúde devem oferecer as informações necessárias para o preparo cognitivo e emocional durante a evolução da doença crônico-degenerativa. De acordo com o autor, a impotência perante a situação de saúde do ente querido revela a gravidade da situação vivenciada, sobretudo quando pouco se sabe sobre a doença e seu desenvolvimento.

Segundo Kovács (2003a), a família pode ser compreendida como um organismo que na situação de intrusão pela doença irá se reorganizar em termos de estruturação e execução de papéis. Contudo, essa reestruturação será desenvolvida de modo particular, num ritmo próprio àquele sistema. Para Rolland:

O psicólogo pode ajudá-las [as famílias] a priorizar tarefas e tomar ações diretas, tais como reunir informações sobre a doença e recursos da comunidade. Informar sobre sintomas significativos e aqueles de pouca importância pode evitar um desgaste emocional desnecessário. Qualidade e quantidade de tempo são prioridade àqueles que enfrentam antecipação da perda na fase final de uma doença. Fazer as pazes consigo mesmo, com a família e com o mundo é uma tarefa fundamental no enfrentamento de uma ameaça de perda, especialmente na fase terminal. (Rolland, 1998 citado por Fonseca, 2004, P. 173)

Tais recursos auxiliam na reorganização subjetiva quanto objetiva, no entanto, mesmo nessas condições, não há a eliminação do impacto que a morte gera no sobrevivente. A família deve ser incentivada pelo psicólogo a participar do processo de cuidado, seja no domicílio, ou em unidades paliativistas, pois a proximidade de acordo com Kovács (2003a) diminui o sentimento de culpa por terem feito tudo o que podiam.

De acordo com Franco (2018) existe a necessidade de avaliar os riscos de luto complicado no enfrentamento do luto antecipatório pelos familiares. Tendo como ponto de partida o entendimento do ser humano como um ser vincular, e que o rompimento parcial de um vínculo pode impactar profundamente, temos que, no luto complicado:

... o enlutado tenta negar, reprimir ou evitar aspectos da perda e impedir o desligamento da pessoa perdida. Resumidamente, se durante a doença e após a perda, o enlutado apresentar dificuldade em aceitar a nova realidade, expressar sua dor, assumir novos papéis, retomar as atividades como realizava anteriormente à perda, lidar com a ambivalência de seus sentimentos e não construir sentido e significados para esse novo momento de sua vida e para a perda, pode-se entender que esteja vivendo um luto complicado. É importante ressaltar, porém, que essas características sofrem modificações de acordo com a cultura na qual o enlutado está inserido. (Franco, 2018, p. 232) 
Durante todo o processo de adoecimento, os familiares percorrerão diversos estágios adaptativos. Esses estão relacionados ao modelo de fases do luto descrito anteriormente, no entanto, é necessário ponderar que há uma variação dentro deste sistema na qual cada um pode vivenciar uma etapa diferente (Parkes, 1998).

De acordo com Pine (1986), quando um luto se apresenta, um outro luto pode estar sendo silenciosamente reexperimentado, principalmente se este pesar anterior não tenha sido resolvido. Nesse sentido, o autor propõe uma série de pontos importantes para a ação do psicólogo e/ou da psicóloga, como a investigação sobre mudanças que tenham ocorrido na vida do indivíduo, os motivos que envolvem o processo de terminalidade e o que impede a morte do ente adoecido.

Os profissionais de psicologia, ainda segundo Pine, devem buscar também informações sobre a vivência de mortes pregressas, já que estas influenciam o modo como o indivíduo lida com o processo de morrência. Outra questão relevante é que cada pessoa deverá ser tratada como um ser único, mas também social, já que as suas reações transparecem os dilemas individuais e familiares relacionadas à relação com o próprio falecido. E, por último, o autor orienta que o terapeuta deve reconhecer que a morte real ou antecipada de uma pessoa em particular tem tantos efeitos diferentes quanto os indivíduos que experimentam a perda.

Parkes (1998) alerta que o terapeuta não deve ser cego às influências sociais e culturais da família que está atendendo. Muitos comportamentos estão relacionados à forma com que uma família lida com questões profundas e, também, como a cultura, a sociedade e a comunidade que está inserida.

Até o momento, foi apresentado brevemente os pontos importantes em relação ao manejo em contexto de luto antecipatório junto ao paciente e junto aos familiares. No entanto, uma terceira modalidade se mostra frequente e extremamente relevante, que é o manejo entre paciente e familiar simultaneamente. Ponto central deste tipo de intervenção tem como base a legitimação das necessidades subjetivas e objetivas do sistema como um todo. O psicólogo, nesse tipo de intervenção, deve garantir a escuta horizontal, oferecendo acolhida tanto ao luto vivenciado pelo paciente quanto ao luto experienciado pelos familiares, estando sensivelmente atento às possíveis interdições impostas pelo tabu social da morte (Rando, 1984; Pine, 1986; Gonzaga, 2012). Nesse sentido, o profissional trabalhará principalmente com o descongestionamento das vias de comunicação. Sendo assim, para que isso ocorra, deve ser estimulado um diálogo aberto, em ambiente acolhedor. 
Kovács (2003a), alinhada à Kübler-Ross (1998b), aponta que os distúrbios de comunicação são afigurados pela literatura especializada como um fator de risco. De acordo com a autora, muito tempo e energia se perdem na tentativa de afastar a verdade. Neste jogo, os familiares tentam proteger o paciente emitindo comunicações contraditórias (verbalmente expressam que está "tudo bem" e corporal demonstram o sofrimento contido) e, por outro lado, o paciente, para preservar a família consente à tal conspiração do silêncio, mesmo intuindo ou sabendo de sua condição, não quer sobrecarregar a família com tal tema.

Diante deste cenário, o psicólogo deve auxiliar legitimando sentimentos (ambivalentes ou não), facilitando a comunicação e estando sempre alerta para os perigos da negação e da identificação, principalmente quando a morte demora a ocorrer. Contudo, permanecer mergulhado no cuidado é algo perigoso, o que deve também ser pontuado pelo profissional que assiste ao caso. De acordo com Kovács (1992), Franco (2002) e Gonzaga (2012), é um risco estar o tempo todo ligado ao outro, já que isso pode interferir na saúde psíquica, social e física. De acordo com Stroebe et al (2001), o esforço para se distanciar dos pensamentos intrusivos do processo de luto se afigura como um tipo de estratégia que também faz parte do processo de adaptação à perda. Afinal, não há comprovação de que as pessoas que vivenciam o luto apenas em seu aspecto doloroso se ajustam melhor do que aquelas que eventualmente recorrem à manipulação de pensamento.

Nesse sentido, Silva (2004) esclarece que ora confrontar a perda iminente e seus aspectos negativos e ora buscar a evitação da dor pode ser benéfico, desde que não haja uma predominância acentuada de um ou de outro modo de comportamento. Sendo assim, o psicólogo deve auxiliar a família na divisão das tarefas, e incentivar que os familiares cuidadores realizem outras atividades que não estejam ligadas ao cuidado, preservando assim aspectos da individualidade.

Quando o paciente está sendo assistido em casa, tal questão fica mais ainda em evidência, já que é necessário o seu acompanhamento diuturno, muitas vezes sem esquemas de folga. A centralização do cuidado, segundo Gonzaga (2012), apresenta-se como questão perigosa, principalmente quando esta se afigura como uma faceta da predominância da orientação à perda descrita pelo Modelo do Processo Dual, indicando dificuldades no processo de luto antecipatório. Manter uma proximidade acentuada com o paciente é desejável para o cuidador, até mesmo para que a "morte social” daquele seja evitada. Contudo, quando essa proximidade é excessiva, tende a acarretar, uma série de 
obstáculos à reorganização da vida após a perda (Mazorra, 2009). Fonseca (2004) afirma que em contexto de assistência domiciliar o terapeuta:

. . . deverá concentrar-se na realidade atual dos pacientes sem deixar de lado eventuais fatos históricos que estejam associados com a situação presente. Nos casos de famílias com pacientes terminais, por exemplo, o psicólogo poderá assisti-los na sua experiência de sofrimento, de elaboração ou enfrentamento de perdas, até às adaptações e reconstruções de vida. (Fonseca, 2004, p. 48)

O autor supracitado com sua produção acadêmica pode contribuir ostensivamente com a produção de conhecimento acerca do luto antecipatório em contexto domiciliar. Contudo, seus estudos e sua prática foram dedicados ao contexto em que um dos integrantes da família se apresentava com o diagnóstico de câncer em estágio avançado, o que se difere em parte do luto antecipatório de familiares que têm um de seus entes acometidos por doença crônico-degenerativa que gera outros impactos na vida dos envolvidos.

Para o autor, o psicólogo e/ou a psicóloga devem participar, na medida que lhe cabe, da dinâmica familiar, podendo utilizar técnicas e o aporte teórico advindos de diferentes origens como a Teoria do Apego de Bowlby, Terapia Familiar Sistêmica, Psicodrama e outros para realizar sua intervenção. No entanto, segundo o autor:

Não existe também uma estratégia clínica correta e única para se utilizar com as famílias que experienciam uma doença terminal. Nestes casos, o terapeuta precisa ajudar as famílias a identificar suas preocupações, compartilhar aspectos sobre as situações circunstanciais e vitais de modo honesto, tomar decisões e apoiarem uns aos outros, enfrentar a inevitabilidade da morte (Fonseca, 2004, p.49).

Pine (1986) afirma que não parece útil para o profissional a busca de técnicas precisas para ajudar as pessoas enlutadas. No entanto, nem sempre o processo de luto antecipatório é levado a termo pelos familiares. Sendo assim, o psicólogo deverá, dentro da ética profissional, incentivar tal trabalho.

Ainda hoje as questões do luto antecipatório no que tange os familiares de pessoas que estão adoecidas gravemente por doenças crônico-degenerativas (características, diferenças, manejos e sua ação no atendimento domiciliar) têm sido pouco discutidas (Duarte et al., 2013; Gonzaga, 2012, 2015; Langaro, 2017). A pouca atenção a esse tema nas pesquisas e produções acadêmicas revela uma lacuna importante a ser contemplada. A falta de orientações claras e bem estruturadas, principalmente com relação ao manejo, causa dificuldades aos profissionais que podem sentir falta de um aporte consistente para suas intervenções. De acordo com Gonzaga (2012), o trabalho do psicólogo no contexto de luto antecipatório deve ser muito bem estruturado a partir de avaliações, do diagnóstico situacional e de uma atuação bem sustentada técnica e humanamente. Nesse sentido, é 
necessária a criação de um modelo de intervenção psicoterápica que possa ser aplicado junto aos familiares atendidos em setting domiciliar e que possa servir de guia para tal atuação.

\subsection{A compreensão do luto e do luto antecipatório do ponto de vista da Psicologia Analítica}

Quando a morte de um ente querido é anunciada por meio do diagnóstico de uma doença grave ou realizada pelo óbito em si, podemos pensar sob o olhar da Psicologia Analítica em inúmeras reações e mudanças de dinâmicas frente à intrusão da notícia e, também, frente à nova realidade que se apresenta para a família. No item que se inicia, serão tratadas as questões do luto e da relação do ser humano com a morte a partir do ponto de vista de Jung e de alguns pós-junguianos. Para iniciar, trataremos de aspectos gerais da teoria, trazendo conceitos chave que serão utilizados no decorrer da pesquisa. Será apresentada a noção geral do que Jung compreende por estrutura psíquica e seus componentes como inconsciente (pessoal e coletivo), consciente, arquétipo, complexo, ego, persona, sombra, self, anima/animus e dimensão simbólica.

Em seguida será apresentado um esboço acerca do modelo ontológico de Jung para caracterizar o que é o ser humano para o autor. Aqui tratarei de temas como: o que impulsiona o ser humano, a partir de qual quadro, ou de qual ponto de vista parte Jung em sua teoria e sua clínica? Como o autor vê o ser humano? Em seguida, dedicarei à apresentação do desenvolvimento humano do ponto de vista da Psicologia Analítica, com o objetivo de auxiliar na compreensão mais aprofundada da psique e do conceito chave desta escola: o processo de individuação. E, para finalizar, tratarei aqui das contribuições de Jung para a compreensão dos processos relacionados à morte, dando relevo à sua percepção do luto de si e do luto pela perda do outro afetivamente vinculado e, por fim, abordarei a perspectiva simbólica da morte tanto em sonhos quanto nos mitos.

\subsubsection{Quadro geral da teoria analítica para compreensão do luto}

Realizadas as devidas compreensões acerca do que é o luto, luto antecipatório e a ação da Psicologia neste contexto, passo agora a apresentar os elementos para elaborar o quadro pelo qual irei tratar o fenômeno e o manejo do luto de familiares. No presente item pretendo esboçar uma noção básica do arcabouço teórico da Psicologia Analítica, integrando a este quadro a ontologia e o desenvolvimento psíquico do ser humano. O 
objetivo aqui é realizar um recorte na teoria junguiana para que o leitor possa ser orientado para o desenvolvimento dos objetivos da pesquisa.

\subsubsection{Aspectos gerais da Psicologia Analítica}

A Psicologia Analítica é uma escola baseada no arcabouço teórico desenvolvido pelo psiquiatra e psicoterapeuta suíço Carl Gustav Jung, (1875 - 1961), colaboradoras e colaboradores. Apesar de Jung ter sentimentos contraditórios relacionados a construção de uma escola junguiana ${ }^{4}$ devido aos riscos de dogmatismos, consolida uma linha teóricoprática extremamente consistente na Psicologia (Samuels, 1989). No campo atual da Psicologia Analítica temos convergências e divergências importantes, e a presença marcante de três linhas gerais: a "clássica", a qual mais alinha a presente pesquisa, a "arquetípica" e a "desenvolvimentista".

Jung, durante sua vida, trabalhou com nomes importantes, como Bleuler e Freud, e recebeu influências da filosofia, da sociologia, antropologia, arqueologia, da filosofia oriental, das artes e outras áreas (Oliveira \& Callia, 2005; Silveira, 1981). Jung construiu um corpo teórico próprio, apesar da profunda relação com outros teóricos, como Freud, no início da carreira, momento em que muitos fenômenos/estruturas psíquicos foram conjuntamente investigados. Refiro a esse momento apenas para contextualizar a aproximação histórica entre Jung e Freud, visto que irei utilizar alguns pontos tratados pelo psicanalista Winnicott para seguir com o objetivo do trabalho. É importante alertar que tanto na Psicologia Analítica quanto na Psicanálise existem muitos conceitos que receberam o mesmo nome, mas são relativos a compreensões totalmente díspares, como, por exemplo, o conceito de inconsciente, libido, dentre outros ${ }^{5}$. Não cabe introduzir aqui todas as diferenças entre a Psicologia Analítica de Jung e a Psicanálise de Freud, mas

\footnotetext{
${ }^{4}$ De acordo com Samuels (1989) apesar de Jung não incentivar a criação de uma escola por entender o perigo que residia na institucionalização de seus constructos, como, por exemplo, o risco de que tal estruturação pudesse permitir excessos autoritários, o autor, se dedicou pessoalmente à construção dos cursos de formação com o intuito de tentar preservar aspectos importantes na formação de terapeutas e que não poderiam ser deixados desprotegidos sem um rigoroso quadro no qual teoria e desenvolvimento pessoal se convergissem. Outro ponto importante é que Jung relutava em afirmar seus constructos enquanto escola porque entendia a importância fundamental da noção de individuação e sua implicação na ampliação e contribuição de pós-junguianos para o desenvolvimento teórico e prático para a Psicologia.

${ }^{5}$ Lembrando que tanto Freud quanto Jung foram, ao longo do tempo, desenvolvendo seus conceitos. No caso de Jung, ele aprimora e modifica sua forma de trabalhar os conceitos, partindo no início da carreira de um ponto de vista mais relacionado à visão médica, biologicista, e no final da vida trabalhando mais afinado com os diálogos com a alquimia, tornando os conceitos mais metafóricos, relacionais e envolvidos com o mundo.
} 
deixo clara a existência de inúmeras divergências. Neste ponto da minha pesquisa, meu objetivo é poder traçar um quadro geral que torne possível vislumbrar como Jung compreende a psique humana para, a partir daí, ampliar a compreensão do processo de luto, bem como configurar uma perspectiva de tratamento psicoterápico, aproximando este do manejo do luto antecipatório para o aperfeiçoamento dessa prática de cuidados.

Para Jung, a psique humana é constituída pela seguinte estrutura: uma camada inconsciente e outra consciente que interagem dinamicamente. Grosso modo, o inconsciente é composto por uma base arquetípica e é dividido em inconsciente pessoal e coletivo. Ao longo da vida, esta base receberá diversos conteúdos advindos das experiências humanas que constelarão em polaridades e formarão composições denominadas complexos. A consciência é "organizada” pelo ego, constituído também como um complexo, porém é o arquétipo do self quem opera como centro da psique, e paradoxalmente como centro regulador do inconsciente coletivo. $\mathrm{O}$ inconsciente, de modo geral, é composto não apenas pelo material que foi reprimido da consciência, por ocasião da incompatibilidade com o caráter do indivíduo, mas também por todo o material no qual a psique foi exposta e que está subjacente aos limites da camada consciente incluindo aí as percepções dos sentidos (Jung, 2013c; 2013e; 2013f; 2013h).

Contudo, antes de adentrar nos conceitos acima listados tratarei brevemente da questão da energia psíquica (ou libido ${ }^{6}$ ) e alguns modos de funcionamento que a cercam como a compensação, conservação, entropia, regressão, progressão e enantiodromia que também serão importantes para o constructo desta tese. Jung compreende que a psique poderia ser considerada como um sistema energético relativamente fechado, no qual existem variações entre as instâncias inconsciente e consciente. $\mathrm{Na}$ saúde, a energia psíquica fluiria de acordo com esta dinâmica, mas na patologia haveria um desequilíbrio, seja por uma distribuição inadequada ou mesmo por um bloqueio que impede sua fluidez (Jung, 2013i). Para tanto, o autor utilizou-se de conceitos da física ${ }^{7}$, esclarecendo que a

\footnotetext{
${ }^{6}$ Salientando que a libido seria uma metáfora não "substancializada".

${ }^{7}$ De acordo com Jung “. . . como não podemos provar cientificamente que exista uma relação de equivalência entre a energia física e a energia psíquica, não nos resta outra alternativa senão desistir do ponto de vista energético ou postular uma energia psíquica, coisa que seria de todo possível, como operação hipotética. A Psicologia, do mesmo modo que a Física, pode permitir-se o direito especial de formar seus próprios conceitos, como já observara LIPPS, na medida em que é conveniente adotar um ponto de vista energético, e não significa apenas, como já sublinhara WUNDT, com razão, uma mera inclusão em um conceito genérico e vago. Somos, porém, de opinião que vale a pena adotar um ponto de vista energético a respeito dos fenômenos psíquicos, porque são justamente as relações quantitativas, cuja existência no psíquico é impossível negar, que encerram possibilidades de conhecimento que só uma consideração qualitativa ignora" (Jung, 2002, p.12).
} 
energia psíquica é passível de conservação e, também, de equivalência e constância. A energia psíquica se movimenta em diferentes níveis de organização,

O desenrolar do processo energético possui uma direção (um objetivo) definida, obedecendo invariavelmente (irreversivelmente) à diferença de potencial. A ideia de energia não é a de uma substância que se movimenta no espaço, mas um conceito abstraído das relações de movimento. Suas bases não são, por conseguinte, as substâncias como tais, mas suas relações, ao passo que o fundamento do conceito mecanicista é a substância que se move no espaço. (Jung, 2013i, p. 14)

A energia, portanto, não é característica do objeto, não sendo uma qualidade deste. A energia só pode ser apreendida na relação, na sua atuação. De acordo com Jung, o que é preciso salientar num primeiro momento é que, para avaliar o modo de funcionamento da energia psíquica, devemos nos ater aos aspectos quantitativo e compreender o que é subjetivo. Jung entende por subjetivo aquilo que é passível de ser avaliado no campo do individual, em contraste com a estimativa no confronto com o modo de ser geral.

Mas quando se trata da conhecida relação compensadora entre o consciente e o inconsciente, é sumamente importante descobrir a possibilidade de determinar valores para a esfera do inconsciente. Se pretendemos um ponto de vista energético do fenômeno psicológico, devemos ter presente o fato, da máxima importância, de que valores conscientes podem desaparecer aparentemente, não voltando a se manifestar em uma atividade consciente correspondente. Neste caso, devemos esperar, em teoria, que eles apareçam no inconsciente, mas como o inconsciente não nos é diretamente acessível, nem em nós próprios nem também nos outros, a avaliação só pode ser efetuada de modo indireto, isto é, precisamos recorrer a métodos acessórios para realizar as avaliações. Quando é o caso da apreciação subjetiva, o sentimento e a intuição ajudam, sem mais outra, porque se trata de uma função que se desenvolveu e se diferenciou, desde tempos imemoriais, com extremo refinamento. A criança já se exercita desde muito cedo em diferenciar sua escala de valores, ponderando qual dos dois ela mais ama: se o pai ou a mãe; quem é que vem em segundo ou terceiro lugar e quem ela mais odeia. Esta avaliação consciente falha não somente no confronto com as manifestações do inconsciente, como degenera em avaliações claramente falsas, também chamadas "recalques" ou "deslocamento do afeto". Na apreciação das intensidades de valores inconscientes devese, portanto, excluir toda e qualquer avaliação subjetiva. Daí resulta que precisamos de pontos de referência objetivos que nos tornem possível uma avaliação indireta, mas também objetiva. (Jung, 2002, p. 8)

Nos testes de associação livre de Jung, pode-se medir, por meio de mensurações como batimentos cardíacos, tempo de resposta e outros parâmetros a movimentação da energia psíquica. Com estes testes, Jung pode averiguar o funcionamento dos complexos, conceito que será descrito na segunda parte deste item. Mas aqui, de modo geral, é importante apontar que foi por meio do referido teste que o autor verificou que, ao serem disparadas certas palavras para o indivíduo avaliado, existia uma diferença na resposta de reação. Nesse sentido, percebeu-se que algumas respostas exigiam um tempo maior para a reação do indivíduo, o tempo dilatado foi compreendido como o acesso a um complexo, já que tocou em algum conteúdo que atraiu energia para si. Pode-se observar que a energia 
da psique recuou, e a pessoa não conseguiu reagir imediatamente, levando algum tempo a mais para retornar ao consciente a fim de verbalizar uma palavra de reação.

O indivíduo tomado pela constelação do complexo emudece, porque a força constelada absorveu energia gerando um recolhimento, uma não ação. Este fenômeno foi compreendido como processo de regressão. Nele existem dois fatores importantes, sendo o primeiro as experiências vivenciadas pelo indivíduo (que carregam durante a vida), e em segundo a própria constituição do sujeito (cada pessoa reage de modo diferente diante da mesma experiência, por exemplo, uma tragédia é vivenciada de modo x por uma pessoa e de modo y por outra). Faz-se necessário ressaltar que, para Jung, regredir não tem um caráter degenerativo ou de doença, sendo apenas mais um processo psíquico que tem por função possibilitar que a libido (energia psíquica) retorne ao inconsciente para explorar aspectos ainda não desenvolvidos.

Além da regressão, também há a progressão da energia. O movimento da energia psíquica, como dito anteriormente, ocorre entre as instâncias consciente e inconsciente. De acordo com Jung, na progressão, a energia flui do inconsciente para o consciente a fim de auxiliar a adaptação ao meio externo. Em contrapartida, na regressão, a energia flui para o inconsciente, a fim de auxiliar as necessidades internas.

[74] A progressão enquanto processo contínuo de adaptação às condições do mundo ambiente assenta na necessidade vital de adaptação. A necessidade compele o indivíduo a se orientar inteiramente para as condições do mundo ambiente e a reprimir aquelas tendências e virtualidades que servem ao processo de individuação.

[75] A regressão, ao invés, enquanto adaptação às condições do próprio mundo interior, assenta na necessidade vital de satisfazer as exigências da individuação. $O$ homem não é uma máquina, no sentido de que poderia manter constantemente a produção de trabalho; pelo contrário, só poderá corresponder plenamente às exigências da necessidade exterior de maneira ideal, se se adaptar também a seu próprio mundo interior, ou seja: se entrar em harmonia consigo mesmo. E, inversamente, só poderá adaptar-se ao seu próprio mundo interior e estar em harmonia consigo mesmo, se se adaptar também às condições do mundo exterior. (Jung, 2002, p.28)

Nesse sentido, a energia progride para alcançar novos projetos, como, por exemplo, casar-se, ter filhos, formar-se, lutar por uma promoção no trabalho. Mas, com o tempo, a energia que foi empregada no novo "projeto" perderá força, porque entropicamente a energia tende ao equilíbrio, ao estado mais estável. Sendo assim, naturalmente a libido regride, mesmo que a consciência não deseje desligar-se do "projeto" (ou compreenda que seja errado desligar-se), seja por culpa, medo, senso de obrigação etc. Um exemplo para este processo seria a própria síndrome do ninho vazio.

No início da vida, os pais e as mães precisam dedicar-se intensamente aos seus bebês, e às suas crianças. No entanto, os filhos crescem e, num determinado, momento 
seguem suas vidas. Em uma fase mais madura, os filhos saem de casa porque passaram em uma universidade fora da cidade natal, mudam-se por causa de um emprego, ou até mesmo porque se casam. Pode acontecer que o pai ou a mãe, ou ambos, não tenham percebido que não existia mais a necessidade de se manter o projeto "cuidar dos filhos" com absoluta atenção. O ego dos pais nesta situação, por senso de obrigação, não atualiza que os filhos cresceram e que não precisam mais de tanto investimento. Não percebe que poderia ter investido parte de sua energia vital em outras atividades, conquistas tão grandiosas e prazerosas. Dessa forma, o ego desatualizado e seguindo um comportamento unilateral, sente profundamente quando os filhos saem do ninho. A energia dedicada obrigatoriamente perde o objeto de atenção e o luto é vivenciado. Neste caso, os relatos são de sensação de vazio, angústia, perda do prazer, sensação de estar perdido, languidez. Essas sensações remetem a um momento de regressão da psique, que pode estar relacionado a um processo de adaptação, um mergulho no inconsciente que permitirá a busca de novas saídas, e talvez um novo projeto.

Contudo, se ocorrer a manutenção do projeto "cuidar dos filhos intensamente", e o ego permanecer em um comportamento unilateral, não levando em conta o que está acontecendo, serão produzidos sintomas neuróticos. De acordo com Jung (2013i), uma ou outra função pode ser negligenciada por um certo tempo, mas não é saudável a manutenção do comportamento unilateral no sentido de que gradualmente poderá haver erupções de conteúdos sombrios com ações desajustadas no mundo exterior. Estés (2014) traz uma imagem interessante para apresentar tal situação: a da mãe-boa-demais, que amamenta uma ninhada de adultos. Neste exemplo, Estés (2014) mostra a situação de mulheres presas ao comportamento persistente de continuar sendo uma mãe-boa-demais, mansa e nutridora que, por diversos motivos, não percebe a toxicidade da situação de continuar cuidando de filhotes adultos. Esta metáfora traz uma cena do campo do absurdo justamente para impactar o leitor a perceber que algo deve ser reconhecido e transformado. Esta mulher que mantém este comportamento unilateral, sendo boazinha demais, poderá ser invadida por conteúdos sombrios, como aqueles relacionados ao aspecto da bruxa devoradora, aspectos negativos do arquétipo da grande mãe, que engole o outo e a si.

Às vezes, a mulher está tão enredada sendo a mãe-boa-demais de outros adultos que eles se grudaram às suas tetas e não pretendem deixar que ela os abandone. Nesse caso, a mulher tem de afastá-los a coices e continuar assim mesmo.

A psique sonhadora procura compensar aquilo que o ego não quer ou não pode reconhecer, entre outras coisas, os sonhos da mulher durante uma luta dessas serão 
compensatoriamente cheios de perseguições, becos sem saída, automóveis que não pega, gravidezes interrompidas e outros símbolos de que a vida não prossegue. Nas suas entranhas, a mulher sabe que existe um toque de morte ao insistir em ser aquela pessoa boa demais por muito tempo. Portanto, o primeiro passo consiste em afrouxar nossa dependência do refulgente arquétipo da mãe-boa-demais-e-sempre-gentil da nossa psique. Largamos a teta e estamos aprendendo a caçar. Há uma mãe selvagem à espera para nos ensinar. (Estés, 2014, p.102)

Dessa forma, no processo de amadurecimento a mulher, ao perceber $\mathrm{o}$ comportamento unilateral de ser boa-demais, deve tornar este modo cada vez mais rarefeito, investindo tempo e energia na descoberta de que pode e deve cuidar de si mesma, a despeito do que o ambiente espera ou exige dela. Resumidamente, embora a progressão e a regressão tenham sua origem na natureza dos processos vitais e nos atravessamentos das condições do ambiente, devemos pensar que estes são processos ou meios de transição do processo energético. A progressão como sendo um trabalho de adaptação, e a regressão como um meio para a manifestação do mundo interior no exterior, produzindo outras maneiras de progressão, mas de uma natureza transformada, seguindo com as adaptações ao mundo externo.

[76] Embora a progressão e a regressão tenham a sua causa na natureza dos processos vitais, de um lado, e nas condições do mundo ambiental, do outro, devemos 66enomina66-las apenas como meios ou pontos de transição do processo energético, caso as analisemos do ponto de vista energético. E sob este ângulo que têm lugar a progressão e o trabalho de adaptação daí resultante como meio para a regressão, isto é, como meio para a manifestação do mundo interior no mundo exterior, produzindo-se, assim, um novo meio para uma nova progressão de natureza modificada, que é uma adaptação melhor às condições do mundo ambiente. (Jung, 2002, p. 29)

Outros postulados que Jung tratou foram a compensação, e os princípios da conservação, entropia, constância e equivalência. Por compensação, Jung (2013i, 2013e) entende como uma equilibração, uma autorregulação do aparelho psíquico. A conservação da energia acontece numa dinâmica entre o consciente e o inconsciente, tal qual o ciclo da água, na qual as partículas da água estarão em alguma etapa do ciclo, e não se perderão no espaço ${ }^{8}$.

\footnotetext{
${ }^{8}$ Nas palavras de Jung: "Neste sentido, considero a atividade do inconsciente (v.) como equilibração da unilateralidade da atitude geral, causada pela função da consciência. Os psicólogos gostam de comparar a consciência ao olho. Fala-se de um campo visual ou centro visual da consciência. Esta comparação caracteriza bem a natureza da função da consciência: só poucos conteúdos chegam ao mais alto grau de consciência e apenas reduzido número de conteúdos pode estar ao mesmo tempo no campo da consciência. A atividade da consciência é selecionadora. A seleção exige direção. E direção exige exclusão de todo o irrelevante. Disso resulta obviamente certa unilateralidade da orientação da consciência. Os conteúdos excluídos se inibidos pela direção escolhida caem, em princípio, à orientação consciente também cresce e conduz finalmente a uma tensão notória. Esta tensão significa certa inibição da atividade consciente que, no entanto, pode ser rompida por um acréscimo de esforço consciente. Mas, com o tempo, a tensão aumenta de tal forma que os conteúdos inconscientes inibidos se comunicam com a consciência, sobretudo por meio dos sonhos ou de imagens de 'livre ascensão'. Quanto maior a unilateralidade da atitude consciente, maior a oposição dos conteúdos provém do inconsciente, de modo que podemos falar de verdadeiro contraste
} 
O princípio da conservação revela que a energia psíquica se mantém conservada no sistema, mas ela pode estar em lugares opostos e, muitas vezes, impossível averiguar onde está localizada. Contudo, se não encontramos energia localizada em $\mathrm{X}$, ela com certeza estará localizada em outro lugar. Não desapareceu no sistema, não foi destruída, apenas mudou de formato ou localização. No caso de ter uma postura perseverantemente unilateral, polarizada em X, regredida ou progredida, a compensação fará esta energia ricochetear em - X, no polo oposto, consciente ou no inconsciente.

Para Jung (1912/1986) a depressão representa um esvaziamento da libido na consciência o que leva a um acúmulo de energia no inconsciente. Através do sistema de auto regulação da psique ocorre uma introversão involuntária como forma de compensação a uma atitude unilateral da consciência: há um esvaziamento de energia no ego que pode se manifestar como depressão. Se os conteúdos do inconsciente forem assimilados e integrados, há uma renovação e transformação na consciência. A depressão vista desta forma não é necessariamente patológica e está associada ao processo necessário de transformação da personalidade. [...] Para este autor, a depressão é vista como uma iniciação, um rito de passagem da alma. Recebemos a visita de Saturno quando vivemos um processo de luto e é esperado que sentimentos de tristeza, desespero, dor, desamparo, raiva e inconformismo estejam presentes, pois fazem parte das reações do luto. (Parisi, 2009, pp. 56-57)

O princípio da entropia orienta que os sistemas passam sempre de um estado de maior energia e menor estabilidade para um estado de menor energia e maior estabilidade. De acordo com Jung, a diferença de energia é que permite o movimento, a vida. No sistema psíquico, uma polarização aguda carrega em si grande quantidade de energia e, consequentemente, grande conflito e instabilidade, exigindo do sistema psíquico um esforço muito intenso para manter este estado energético (tensão) por um longo período. A entropia revela como se dá o direcionamento da energia, ou seja, sempre do alto para o vale, na qual haverá maior estabilidade.

As transformações de sua energia também nos levam a um processo de nivelamento entre as diferenças que, no dizer de BOLTZMANN, passam de um estado improvável a um estado provável. Isto, entretanto, reduz cada vez mais a possibilidade de uma modificação posterior. Observamos este processo, por exemplo, no desenvolvimento de uma atitude permanente e relativamente inalterável. Depois de oscilações inicialmente violentas, os opostos tendem a equilibrar-se e surge pouco a pouco uma nova atitude cuja estabilidade subsequente será tanto maior, quanto mais acentuadas tiverem sido as diferenças iniciais. E quanto mais forte for a tensão entre os opostos tanto maior será a

entre consciência e inconsciente. Neste caso, a compensação se manifesta em forma de função contrastante. Este é um caso extremo. Em geral, a compensação pelo inconsciente não é um contraste, mas uma equilibração ou complementação da orientação consciente. O inconsciente dá, por exemplo, no sonho, todos os conteúdos constelados para a situação consciente, mas inibidos pela seleção consciente, cujo conhecimento seria indispensável para a consciência se adaptar plenamente. Em situação normal, a compensação é inconsciente, isto é, atua de forma inconscientemente reguladora sobre a atividade consciente. Na neurose, o inconsciente está em contraste tão forte com a consciência que a compensação fica prejudicada. Por isso, a terapia analítica procura uma conscientização dos conteúdos inconscientes para restabelecer a compensação". (Jung, 2013j, pp. 437-438). 
quantidade de energia daí resultante, e quanto maior for esta energia, tanto mais intensa será a força de atração consteladora (Jung, 2002, p.19).

Após o extravasamento que acontece no conflito, vem a bonança ou o destroçamento, a dispersão de energia. Este fenômeno ocorre a fim de equilibrar a energia do inconsciente e do consciente. No item sobre entropia, Jung (2002) diz:

[50] A experiência psicológica de todos os dias nos dá abundantes provas da justeza desta afirmação: os conflitos mais penosos, quando superados, deixam na sua esteira uma segurança e uma paz ou então um destroçamento que será difícil de modificar ou difícil curar, e inversamente: serão necessários precisamente contrastes fortíssimos e sua conflagração, para que se produzam resultados valiosos e duradouros. Como nossa experiência só atinge sistemas relativamente fechados, nunca nos encontraremos em condições de observar diretamente uma entropia psicológica absoluta. Entretanto, quanto mais fechado é um sistema, tanto mais claramente se manifesta o fenômeno da entropia. Observamos isto, de modo particular, nos distúrbios mentais que se caracterizam por bloqueios intensos ao meio ambiente. O chamado "embotamento dos afetos" na dementia prae cox [demência precoce] ou esquizofrenia pode ser considerado como um fenômeno da entropia. (Jung, 2002, p.19)

Por "enantiodromia", Jung entendia como o princípio relativo ao movimento no

qual, quando houvesse uma concentração excessiva de energia em um ponto, a energia tenderia a buscar o ponto oposto com o intuito de manter o equilíbrio.

Nas palavras de Jung (2013j):

Enantiodromia. Significa 'correr em sentido contrário'. Com este conceito se designa, na filosofia de Heráclito, o jogo de oposição no devir, ou seja, a concepção de que tudo o que existe se transforma em seu contrário. 'O que vive morre, o que estava morto renasce; o que é jovem envelhece, o que é velho volta a ser jovem; o que está acordado dormirá, o que dorme acordará; a corrente da criação e da destruição não para jamais'. Pois criar e destruir, destruir e criar, esta é a norma que governa todos os ciclos da vida natural, desde o menor ao maior. O próprio cosmos que saiu do fogo primitivo voltará a ele - processo dúplice que se completa em períodos fixos, ainda que de tempos incomensuráveis, e volta a correr sempre de novo'. Essa é a enantiodromia de Heráclito segundo as palavras de intérpretes qualificados. Várias são as expressões do próprio Heráclito que atestam este ponto de vista. Diz ele: 'A própria natureza procura o antagônico e dele tira a harmonia e não do idêntico' (Jung, 2013j, p. 443).

Aplicando psicologicamente seu princípio, diz Heráclito 'Tomara que nunca vos faltem riquezas, ó efésios, para que vossa depravação apareça à luz do dia' Com o termo enantiodromia quero designar a oposição inconsciente no decorrer do tempo. Este fenômeno característico ocorre quase sempre onde uma direção extremamente unilateral domina a vida consciente de modo que se forma, com o tempo, uma contraposição inconsciente igualmente forte e que se manifesta, em primeiro lugar, na inibição do rendimento consciente e, depois, na interrupção da direção consciente. Bom exemplo de enandiodromia é a psicologia de São Paulo e sua conversão ao cristianismo, também a história da conversão de Raimundo Lulo, a identificação com cristo do doentio Nietzche, seu endeusamento de Wagner e sua hostilidade posterior contra ele, a transformação de Swedenborg de sábio em visionário etc. (Jung, 2013j, p.444)

A questão da compensação será mais bem tratada no próximo item, no qual tratarei

do processo de luto e do caso de uma paciente de Jung. Por hora, encerro esta breve 
exposição dos conceitos apresentados sobre o sistema psíquico e algumas de suas características e passo a aprofundar os conceitos centrais em sua teoria. Para tal, iniciamos com o conceito de inconsciente, seguindo com os conceitos de arquétipo, complexo, sombra, ego, self, persona dentre outros.

O inconsciente é a parte da psique que recebe e transmite a herança psíquica humana. Para Jung, o inconsciente é um manancial de imagens que sempre está ativo, realizando a atividade de agrupar e reagrupar conteúdos. Seu funcionamento nunca se encontra em estado de repouso. Em situação de saúde, suas atividades se encontram coordenadas com a consciência, numa relação de compensação, se apresentando como "sementes de futuros conteúdos conscientes" (Jung, 2013e, p. 16). O inconsciente é composto por duas camadas: o inconsciente pessoal e o inconsciente coletivo. De acordo com Jung (2013e; 2013h), o inconsciente pessoal está relacionado aos conteúdos pessoais que foram adquiridos durante a existência do sujeito. $\mathrm{O}$ inconsciente pessoal é apenas uma camada do que ele denominou de inconsciente, havendo mais profundamente uma outra, mais ampla, que remete ao coletivo e que não se esgota ao ser acessada. Essa instância mais profunda é reativada na dinâmica psíquica. Contudo, sua movimentação é menos ativa do que a movimentação na camada pessoal (Jung, 2013e).

No inconsciente coletivo existem os arquétipos ${ }^{9}$ : estruturas, formas sem conteúdo próprio, que têm a função de organizar ou canalizar os conteúdos psicológicos. Nesse sentido, é na camada pessoal do inconsciente que os seres humanos vivenciam as imagens arquetípicas dentro das possibilidades de sua própria experiência pessoal. Diante disso, Jung (2013d; 2013e; 2013h) afirma que o ser humano não nasce uma tabula rasa, já que herda da coletividade esta base arquetípica. O arquétipo é universal, atemporal e não espacialmente localizado, é tão absoluto que se torna inapreensível, um pressuposto. É uma predisposição inata para formarmos imagens psíquicas, uma matriz de onde se manifestam as imagens arquetípicas que não estão prontas, mas formam-se a partir das experiências vividas pelo indivíduo.

Jung chega à compreensão da estrutura psíquica tanto pela observação nos casos clínicos com psicóticos quanto comparando com a biologia da estrutura das células. De acordo o autor, cada célula tem suas funções individuais que especificam sua tarefa no órgão em que atuam, mas, ao mesmo, tempo possuem gravadas em si toda a estrutura do

\footnotetext{
${ }^{9}$ É importante notar que o conceito de arquétipo se modifica ao longo da obra junguiana, saindo de uma formulação inicial relacionada ao evolutivo/biológico para um conceito limítrofe e simbólico, imaginal na alquimia.
} 
DNA de sua espécie. Sendo assim, temos que o ser humano tem suas especificidades, mas herda de seus ancestrais tanto os órgãos físicos, quanto os "órgãos" psíquicos (2013h). Os arquétipos contêm metaforicamente os dados do DNA, pois é constituído por aspectos comuns da história da espécie humana. Segundo Neumann (2014), mesmo com as modificações forjadas no desenvolvimento da humanidade na qual a estrutura psíquica foi aos poucos sendo transformada, houve a conservação de uma estrutura primária e autônoma que desempenha suas funções.

Segundo Whitmont (1995), Jung percebeu que as energias advindas das experiências, sentimentos, percepções, sendo egossintônicas ou egodistônicas, constelavam ao redor de um arquétipo específico, criando um complexo. Um complexo, na teoria Junguiana, é um grupo de imagens relacionadas entre si que têm um acento emocional comum e que se formam em torno de um núcleo arquetípico. Os complexos são unidades vivas e autônomas da psique, e se comportam com independência (Samuels, Shorter, \& Plaut, 1998).

Durante a vida do indivíduo, conteúdos externos e internos seriam agrupados a diferentes arquétipos em polaridades. Contudo, certos pontos ficariam inconscientes e se instalariam nas camadas mais profundas, como na sombra, ao passo que outros se agrupariam mais na superfície, sendo mais acessíveis à consciência. Frente a isso, na dinâmica do dia a dia, certas situações poderiam provocar a constelação desses conteúdos, desses complexos carregados, fazendo com que afetos, mesmo inconscientemente, fossem expostos com vários graus de autonomia. Dessa forma, conteúdos da sombra invadem tanto na neurose quanto na psicose, porém, nos casos mais graves, como na psicose, as atividades autônomas trazem conteúdos profundos, chegando aos conteúdos do inconsciente coletivo.

$\mathrm{Na}$ psicose, independentemente das variações pessoais, Jung afirma que o terapeuta pode lidar com material sadio, base universal da estrutura psíquica. De acordo com Silveira (2018, pp. 178-179): “o problema preliminar será reconhecer a natureza das imagens invasoras do campo do consciente na condição psicótica. As representações que emergem das camadas mais profundas da psique nunca são patológicas em si mesmas". Essa realidade é colocada não no sentido romântico, visto que a loucura tem um aspecto brutal na lida tanto do indivíduo cindido com sua própria psique quanto com o seu entorno. No entanto, estas imagens carregam possibilidades de um contato com uma herança saudável, dentro da possibilidade de cada subjetividade. Sendo assim, o que é patológico, de acordo com Jung, não tem a ver com essas representações, mas com a 
dissociação do consciente devido à cisão do ego que se torna incapaz de controlar as invasões do inconsciente (Silveira, 2018).

De acordo com Silveira (2018), nas psicoses ${ }^{10}$, os conteúdos do inconsciente vêm à tona de modo brutal. Como dito anteriormente, para a Psicologia Analítica, o elemento patológico não se encontra nos arquétipos, mas na dissociação da consciência que não tem força suficiente para o controle do conteúdo que é jorrado do inconsciente. Nestes casos de dissociação, faz-se necessário o trabalho de integração do que é inconsciente ao que é consciente.

Quando o ego cinde-se, estilhaça-se, seja por incapacidade para suportar a tensão de certas situações existenciais, pelo envolvimento em relações interpessoais destituídas de amor, frustrantes ou opressivas, seja devido ao impacto de emoções violentas ou ao trabalho surdo de afetos intensos, a libido introverte-se, vindo reativar o inconsciente. $\mathrm{O}$ ego, partido em pedaços, não tem forças para fazer face à realidade externa nem tampouco consegue controlar a maré montante do inconsciente.

Em bruscos saltos de desnível a energia psíquica, que se introverteu, vem despertar nas profundezas disposições herdadas para imaginar e agir que de algum modo já foram úteis ao homem arcaico em situações mais ou menos análogas, repetidamente vivenciadas no curso dos milênios. Entretanto, essas respostas são dadas por estranhos figurantes num jogo de cenas espantosas amedrontadoras tanto quanto fascinantes. Se o indivíduo tenta comunicar o que lhe está acontecendo, as pessoas afastam-se sem querer escutá-lo. Seu isolamento torna-se cada vez maior. Chamam-no então de 'alienado'.

O problema preliminar será reconhecer a natureza das imagens invasoras do campo do consciente na condição psicótica.

As representações que emergem das camadas mais profundas da psique nunca são patológicas em si mesmas. (Silveira, 2018, pp.178-179)

É importante dizer que estes conteúdos se apresentam, de forma mais velada, mas também perturbadora, na neurose. Na neurose, essas invasões estão mais ocultas, e aparecem, por exemplo, em forma de sintomas físicos e emocionais. Estes acabam por auxiliar o terapeuta na compreensão dos processos psíquicos durante a análise. Para Jung, o conceito de complexos é altamente importante, considerando-o a via régia para o inconsciente que poderia aparecer em diversas manifestações simbólicas e nos sonhos. Essas manifestações tornam possível a ligação entre os conteúdos pessoais e os conteúdos arquetípicos, dando ao terapeuta a noção de como se apresenta a estrutura psicológica de cada indivíduo, incluindo aqui as conexões entre a experiências e a memória.

Jung (2013a; 2013e) frisa que, quando a análise com neuróticos se aprofunda, entramos em contato também com as figuras arquetípicas que são visíveis nos delírios psicóticos. Os conteúdos que se encontram na camada do inconsciente pessoal podem ser reconhecíveis parcial e integralmente. Inclusive, é possível conhecer sua origem. Todo o

\footnotetext{
${ }^{10}$ Note que o conceito de psicose para a autora foge ao modelo biomédico presente na psiquiatria tradicional.
} 
conteúdo pessoal é agregado em torno dessas imagens ou estruturas primordiais independentemente de um controle voluntário (Neumann, 2014 ). De acordo com Samuels et al. (1998), os arquétipos aparecem com clareza em comportamentos relacionados às experiencias universais da vida humana, como nascimento, maternidade, casamento, separação, morte etc.

Nesse sentido Jung, a partir de sua experiência clínica, percebeu que ocorriam certas interferências ao tentar tratar somente dos conteúdos pessoais em seus pacientes:

Poderíamos também deduzir a possibilidade já mencionada de que, anulando a repressão, impediríamos a descida dos conteúdos psíquicos ao inconsciente, o que estancaria a produtividade deste último. A experiência nos revela que isto só é possível numa proporção muito limitada. Aconselhamos nossos pacientes a reter e assimilar em seu plano de vida os conteúdos reprimidos que foram associados de novo à consciência. Tal processo, no entanto, como verificamos diariamente, não exerce qualquer influência sobre o inconsciente; este continua a produzir tranquilamente sonhos e fantasias, os quais, segundo a teoria original de Freud, deveriam ser motivados por repressões de ordem pessoal. Em tais casos, se prosseguirmos sistematicamente nossas observações, sem preconceitos, depararemo-nos com um material que, embora semelhante aos conteúdos pessoais anteriores, em seu aspecto formal, parece conter indícios de algo que ultrapassa a esfera meramente pessoal. (Jung, 2013e, p. 16)

Desse modo podemos averiguar que o ego, centro da consciência, é um complexo importante. O ego não remete à totalidade do ser humano, mas tende a comportar-se como se fosse a única estrutura, ou a estrutura fundamental. Contudo, o ego é apenas a "casca" desse complexo de identidade. Ele funciona como os outros complexos e tenta se impor em termos energéticos frente aos demais (Whitmont, 1995). De acordo com Jung, o ego é apenas o centro da consciência, enquanto o self, é o centro da totalidade da psique. Neste sentido, o ego está contido no self (Whitmont, 1995).

O ego funciona como centro da identidade pessoal e da consciência, percebendose coeso e contínuo no decorrer da história pessoal. Este complexo é central e protagoniza, pelo menos aparentemente, ações, decisões, julgamentos, e causa os impulsos pessoais que remetem a desejos que definem ações específicas e próprias. No entanto, a identidade constituída por meio dessa estrutura não está relacionada ao desenvolvimento da consciência. Nas palavras de Jung:

A identidade não possibilita a consciência. Somente a separação, o desligamento e o confronto doloroso através da oposição, pode gerar consciência e conhecimento... Hoje é difícil ainda para o homem ocidental reconhecer a necessidade psicológica de um sujeito transcendente do conhecer, como um polo oposto do universo empírico, embora o postulado da existência do si mesmo em confronto com o mundo, pelo menos como um ponto refletor, seja logicamente indispensável. (Jung, 2013h, pp. 173-174) 
Essa concepção do ego, substanciada pelas descobertas do funcionamento psicológico na saúde e na patologia, é uma das características distintas da Psicologia Analítica. Para Neumann,

O complexo do ego é um conteúdo da consciência e, ao mesmo tempo, condição da consciência, uma vez que um elemento psíquico é consciente na medida em que está ligado ao complexo do ego. Considerando-se, no entanto, que é apenas o centro do campo de consciência, o ego não é idêntico à totalidade da psique, mas apenas um entre outros complexos. (2014, p. 192).

Em resumo, temos que o ego é o centro da consciência, ou seja, é ele que fornece um sentido de consistência e direção em nossas vidas conscientes (Whitmont, 1995). Ele tende a contrapor-se a qualquer coisa que possa ameaçar essa frágil consistência da consciência e tenta convencer-nos, por fazer parte de sua função na psique, de que sempre devemos planejar e analisar conscientemente nossa experiência. Somos levados a crer que o ego é o elemento central de toda a psique e chegamos a ignorar sua outra metade inconsciente. Porém, é importante sabermos que suas decisões estão intimamente ligadas aos conteúdos que estão no inconsciente. Ele parece ter total autonomia, mas o conteúdo dos complexos a qualquer momento pode tirar sua independência, invadindo a consciência e deixando com que fique possuído e tenha visões distorcidas da realidade.

O complexo ego cria para fins de adaptabilidade social uma persona (ou personas) que serve justamente para adequação ao meio, mas também para proteger a psique ainda em construção. Para Jung (2008, 2013e, 2013j), a persona é um complexo e um arquétipo, e lançou mão deste nome para justamente trazer a nuance de que a persona é um personagem, algo que não é totalmente real e que, por sua vez, pode ser uma faceta (saudável e/ou patológica). Durante toda a vida do indivíduo serão utilizadas inúmeras máscaras, construídas frente a diversos eixos como: gênero, profissão, status sociocultural, dentre outros (Samuels, et al., 1998). A persona, segundo esta teoria, é a forma pela qual nos apresentamos ao mundo. É o caráter que assumimos; por meio dela, nos relacionamos com os outros. A persona inclui nossos papéis sociais e nosso estilo de expressão pessoal. Hollis (2015) pontua que o ego dispensa grande energia para:

. . . adquirir uma persona, em resposta à socialização. A persona representa uma face necessária a ser apresentada ao mundo exterior e ela também protege nossa vida interior. Mas, do mesmo modo como a confiança da função superior representa uma parcialidade, também a persona é um fragmento do si mesmo. Ela é necessária para podermos lidar com a realidade exterior, mas a psique maior e inexplorada permanece o tempo todo esperando ser reconhecida... Quanto mais investimos numa autoimagem particular, mais desenvolvemos uma adaptação unilateral à realidade, e quanto mais nosso senso de segurança é investido naquilo que nos tornamos . . ., mais as invasões da sombra são ao mesmo tempo necessárias e perturbadoras. (Hollis, 2015, p. 108) 
Como citado anteriormente, a energia dos complexos, quando desvinculada da consciência, passa a atuar no inconsciente, onde continua numa existência relativamente autônoma que influi sobre a conduta do indivíduo. Fato este que, como alerta Jung, deve ser profundamente assistido por se tratar de um condensado de energias polarizadas. Tais energias não reconhecidas vão formando a sombra, que também é um complexo e possui um núcleo arquetípico. Se a polaridade sombria de um complexo for ativada e, se o ego não tiver força ou estrutura para integrá-la ou administrá-la, essa energia pode provocar patologias físicas, psicológicas e/ou sociais.

O ego utiliza da persona para interação social, porém parte dos conteúdos originados dessas vivências são depositados na sombra. A sombra é mais perigosa quando não é reconhecida pelo seu portador. Nesse caso, o indivíduo tende a projetar suas características indesejáveis em outros ou a deixar-se dominar pela sombra sem o perceber. Quanto mais o material da sombra tornar-se consciente, menos ela pode dominar.

A sombra é o centro do inconsciente pessoal, o núcleo do material que foi reprimido da consciência durante toda a vida (Whitmont, 1995). A sombra inclui aquelas tendências, desejos, memórias e experiências que são rejeitadas pelo indivíduo como incompatíveis com a persona e contrárias aos padrões e ideais sociais (energia polarizada e reprimida). Quanto mais forte for nossa persona, e quanto mais nos identificarmos com ela, mais repudiaremos outras partes de nós mesmos. A sombra representa aquilo que consideramos inferior em nossa personalidade e, também, aquilo que negligenciamos e nunca desenvolvemos em nós mesmos. Entretanto, a sombra é uma parte que integra a nossa natureza e nunca pode ser simplesmente eliminada. Uma pessoa que não entra em contato com sua sombra e acredita que não a possui não é uma pessoa completa, mas uma caricatura bidimensional que rejeita a mescla do bem e do mal e a ambivalência presente em todos nós (Whitmont, 1995).

Von Franz ressalta que há complexidades em compreender a dinâmica psíquica, sendo trabalhosa a compreensão da origem e/ou finalidade dos processos que se apresentam com os sujeitos invadidos:

O fato de a sombra ter este poder arrebatador de impulsos irresistíveis não significa que tais impulsos devam ser sempre heroicamente reprimidos. Algumas vezes a sombra é assim poderosa porque o self indica uma orientação idêntica; portanto não sabemos se é o self ou a sombra que nos pressionam. No inconsciente encontramo-nos, infortunadamente, na mesma situação de quem pisa numa paisagem lunar: todos os seus conteúdos estão manchados, enevoados e mesclados uns aos outros, não se sabendo nunca exatamente o que é ou onde está determinada coisa, ou onde ela começa ou acaba. (Marie-Louise von Franz, 2008, p. 229) 
Por fim, tratarei do conceito self. O self é a "totalidade psíquica de um indivíduo e também, paradoxalmente, o centro regulador do inconsciente coletivo" (von Franz, 1990, p.10), tendo um eixo, uma ligação direta com o ego. O conceito de self é paradoxal e abrange a ideia de que o self é o centro da psique; a totalidade da psique; o processo de integração/desdobramento da psique, e também a origem e a finalidade do processo psíquico.

O centro organizador de onde emana essa ação reguladora parece ser uma espécie de 'núcleo atômico' do nosso sistema psíquico. É possível denominá-lo também de inventor, organizador ou fonte das imagens oníricas. Jung chamou a esse centro o self e o descreveu como a totalidade absoluta da psique, para diferenciá-lo do ego, que constitui apenas uma pequena parte dela. (von Franz, 2008, p. 212)

A psique ao longo da vida estará a serviço do self e trabalhará arduamente no processo de individuação, apresentando um sentido teleológico, que aponta para uma finalidade do que nos acontece da vida humana. Este é um processo árduo, que exige escolhas e um confronto entre os conteúdos polarizados que constelam nos complexos de um modo geral, num movimento incessante de imagens e conteúdo na dinâmica consciente/inconsciente.

Todos estes fenômenos e estruturas anteriormente tratadas compõem o self. Ele é o arquétipo do potencial mais original e completo do ser humano. O self como princípio ordenador “... tem a capacidade de coordenar os processos psíquicos, por meio da função transcendente que indica a direção de uma melhor saúde psíquica. O relacionamento egoself vai ocorrer sempre pelos símbolos, alimentando o processo de individuação" (Boechat, 2011, p. 59).

Nesta dinâmica ocorre a atitude simbólica, na qual o símbolo funciona como um fio norteador e a função transcendente auxiliará nas integrações necessárias entre o inconsciente e o consciente. De acordo com Widmer Costa Neto (2018):

Por atitude simbólica compreendemos a atitude fundamental da consciência que considera que há um sentido do fenômeno sendo vivenciado e assim pode reconhecer se alguma coisa é ou não um símbolo. Lembremos que um mesmo evento pode ser simbólico para uma pessoa e não o ser para outra. Também é possível que dado fenômeno seja considerado simbólico para indivíduos que participam de uma mesma cultura e não o seja para os que dela não fazem parte. (p. 31)

A atitude simbólica tem importância na elaboração do símbolo auxiliando no movimento de ampliação e assimilação do novo pela consciência “. . . o que irá possibilitar não só uma eventual ampliação das possibilidades expressivas da consciência, mas também sua transformação" (Widmer Costa Neto, 2018, p. 31).

O self é o arquétipo central responsável pela organização e pela totalidade psíquica. Cabe a ele criar e organizar as imagens trazidas do inconsciente (von Franz, 
2008). Para Jung, o self é uma estrutura universal, e que aparece em diversos povos, recebendo denominações diferentes. Por exemplo, para os antigos gregos, era denominado "daimon"; para os egípcios, "alma-Ba"; os romanos reverenciavam o que eles chamavam de "gênio", considerado por este povo um caráter inato e, nos povos não civilizados, eram os espíritos de proteção, que orientavam, davam força e poder, simbolizados em um animal ou outro objeto específico (von Franz, 2008).

De acordo von Franz

O self pode ser definido como um fator de orientação íntima, diferente da personalidade consciente, e que só pode ser apreendido por meio da investigação dos sonhos de cada um. E esse sonho mostram-no como um centro regulador que provoca um constante desenvolvimento e amadurecimento da personalidade. No entanto, esse aspecto mais rico e mais total da psique aparece, de início, apenas como uma possibilidade inata. Ele pode emergir de maneira insuficiente ou então desenvolver-se de modo quase completo ao longo da nossa existência; o quanto vai evoluir depende do desejo do ego de ouvir ou não suas mensagens. . . o Grande Homem inato torna-se mais real aos que o ouvem do que aos que o desprezam. Ouvindo-o, tornamo-nos seres humanos mais completos. (von Franz, 2008, p.213)

Para entrar em contato com o chamado "grande homem inato" Jung propõe darmos atenção aos aspectos simbólicos. Ao observar os sonhos, por exemplo, o indivíduo pode perceber padrões e as mudanças lentas do desenvolvimento psicológico. De acordo com von Franz (2008) ao assumir uma postura mais incisiva no processo de análise dos sonhos, essas mudanças podem acelerar o processo de crescimento psíquico, se e somente se houver uma análise pertinente dos sonhos e dos símbolos que o compõem. De acordo com Henderson (2008), o ser humano pode achar que os seus sonhos sejam espontâneos, desconexos, porém o terapeuta, ao final de um período de análises, consegue constatar, a partir da série de imagens, uma estrutura significativa. Para dar conta, temos os símbolos: “A função psíquica que cria os símbolos é a função transcendente, que opera a aproximação entre consciente e inconsciente, a partir da necessidade atual de transformação da totalidade" (Penna, 2004, p. 90).

Segundo Boechat (2011), o self produz símbolos que podem orientar e equilibrar a psique rumo a processos curativos. Para o desenvolvimento psíquico, denominado individuação, é importante que haja integração entre os conteúdos conscientes e inconscientes.

A seguir, realizarei um esboço sobre a ontologia do ser do ponto de vista de Jung e, na sequência, tratarei do desenvolvimento humano e o processo de individuação propriamente dito. 


\subsubsection{O modelo de ser humano (ontologia) para Jung}

Jung deixou um vasto arcabouço acerca da psicoterapia, mas também contribuiu com uma teoria inédita "tanto em termos ontológicos quanto epistemológicos e metodológicos, o que nos permite falar de um novo paradigma científico" (Penna, 2004, p.72).

Dentro do modelo ontológico de Jung, o homem e a mulher são seres em desenvolvimento que nascem com uma estrutura primitiva e coletiva, que irá ao longo do tempo se individuar para alcançar o si mesmo.

Ele é impulsionado por forças internas, coordenadas pelo self, que tem a função teleológica de buscar ao longo da vida uma existência original, individuada.

Para Penna (2004), nesse modelo:

A psique constitui uma totalidade que inclui o âmbito inconsciente, relacionado aos fenômenos do mundo subjacente, e o âmbito consciente, relativo aos fenômenos do mundo manifesto. A concepção romântica de uma realidade subjacente interferindo na realidade manifesta e a noção de uma totalidade abrangente movida por padrões organizadores, isto é, arquétipos fora do controle da consciência (Bohm, 2001), constituem a base da ontologia junguiana, que hoje começa a ser aceita por outros paradigmas. (Penna, 2004, p.82)

O sujeito não recebe apenas influências das forças intrapsíquicas, mas também do meio, da história, da cultura, das regras sociais. No quadro de Jung, coexistem e se auto influenciam as dimensões intrapsíquicas (energias, afetos) e interpsíquica (relação com o social, com a geografia, a economia, o clima, a cultura). Ambas têm implicações diretas no desenvolvimento do ser. Na dimensão intrapsíquica, tratada no item anterior, estão presentes camadas do inconsciente e consciente que, no desenvolvimento individual, travarão embates e comunicações rumo à individuação. A dimensão interpsíquica é importante para a socialização, aprendizado coletivo, e a percepção do que é plural e singular.

No paradigma junguiano, a perspectiva ontológica refere-se à natureza da realidade, considerando as concepções de mundo, ser e psique. A noção de totalidade - unidade e diversidade - constitui o pilar básico dessa perspectiva. Trata-se de uma totalidade dinâmica que contém elementos diversos. O mundo, para Jung, é concebido em seus aspectos subjacente e manifesto. A noção de unus mundus, emprestada da filosofia medieval, confere dinamismo ao todo e integra microcosmo e macrocosmo. O ser humano é considerado uma totalidade eco-bio-psico-social, incluindo consciente e inconsciente (Penna, 2003). O homem como microcosmo é parte integrante do macrocosmo, o qual compreende as esferas do inconsciente coletivo e da consciência coletiva (Penna, 2004, pp. 81-82).

Sendo assim, no constructo que constitui a Psicologia Analítica, o sujeito em sua complexidade é impulsionado, a partir da energia de suas heranças psíquicas e das 
primeiras estruturas psicológicas, a interagir com o mundo interno e externo, aprendendo ao longo da vida a lidar tanto com sua parte individual, relacionada ao um si mesmo original, único, mas também com a humanidade toda, vivendo seu aspecto coletivo e plural.

Neste processo, conhecimento e autoconhecimento têm grande importância, pois implicam na estruturação e ampliação da consciência, que levará paulatinamente à individuação: "tal processo constrói a individualidade do ser humano e tem correspondência na constituição das particularidades sócio-históricas da cultura humana" (Penna, 2004, p. 90).

Para finalizar os aspectos importantes, temos a natureza simbólica da humanidade:

O mundo e o ser humano são definidos por sua qualidade simbólica. Dessa forma, o ser humano é um ser simbólico, que vive numa dimensão simbólica. Segundo Cassirer (1944/1997), o homem é um animal "symbolicum", que não vive mais num universo meramente físico. O universo humano é simbólico, estamos diante de uma nova dimensão de realidade: a dimensão simbólica. Esta abarca os aspectos biológicos, ambientais, culturais (sócio-históricos) e espirituais, integrando-os num todo único e típico (Penna, 2004, p. 82).

O contato com a experiência simbólica é a via régia para o processo de individuação, pois ela possibilita conhecer aspectos do inconsciente e as orientações do self. Para Jung, o ser humano, gradualmente e principalmente a partir da metade da vida, vai percebendo sua finitude, mas também o fato de que há algo ilimitado na sua existência. Nas palavras do autor:

A maior limitação do homem é o Si Mesmo ... Somente a consciência de minha estreita limitação no meu Si Mesmo me vincula ao ilimitado do inconsciente . . . É quando torno consciente disso que me sinto ao mesmo tempo limitado e eterno. (Jung, 2006, pp. 281282).

Tal percepção é essencial para que o ser humano não fique preso ao que é fútil, supérfluo, e se aproxime cada vez mais do seu verdadeiro eu, no sentido fenomenológico.

\subsubsection{A teoria do desenvolvimento humano do ponto de vista de Jung e processo de individuação}

Neste subitem, tenho como objetivo trazer uma noção do desenvolvimento psíquico humano com o intuito de demonstrar que, para Jung (e colaboradores), a psique no processo de individuação passa desde a barriga da mãe, como germes da individuação, até o último instante de vida em franco processo de autodesenvolvimento. Aqui apresentarei as fases do desenvolvimento para Jung, utilizando também teóricos analíticos, além do mitólogo Joseph Campbell. Neste subitem também apresentarei 
concomitantemente o conceito de individuação e a implicação desse processo no desenvolvimento humano. Para falar de desenvolvimento da personalidade em Psicologia Analítica, precisamos relacioná-lo ao processo de individuação, processo trabalhoso de transformação que forja as sementes da personalidade rumo a sua realização.

De acordo com Fulgencio, todas as teorias do desenvolvimento apresentam suas explanações levando em conta três aspectos, a saber: dimensão física, cognitiva e socioemocional. Uma teoria do desenvolvimento está interessada na maneira pela qual o comportamento evolui como uma entidade, e não nas funções, órgãos, ou capacidades isoladamente consideradas. O desenvolvimento atravessa estágios distintos, que levam a comportamentos sempre mais complexos; consequentemente, a ontogênese é contínua quando atravessa um estágio, e descontínua quando passa de um estágio para o seguinte, mais elevado (Cobliner, 1965).

Levando em conta esses critérios, Jung não se deteve em construir uma teoria do desenvolvimento a esses moldes, como fizeram, por exemplo, Freud, Anna Freud, Erikson, Mahler, Winnicott. Foge ao escopo do presente estudo aprofundar na temática das faltas, mas colocar em evidência o que foi produzido e completado por outros autores. Aqui realizarei um recorte intencional, não apresentando detalhes de todas as etapas do desenvolvimento, mas exibindo ao leitor, como anunciado anteriormente, um panorama geral para maior compreensão do processo de individuação.

Jung tratou em seu arcabouço teórico o desenvolvimento psíquico, levando positivamente em consideração os aspectos sociais, emocionais e cognitivos da infância ao envelhecimento. Espalhados por toda sua obra, Jung trata a questão do início do desenvolvimento, mas é no livro $O$ desenvolvimento da personalidade que o autor explora mais enfaticamente o início da vida psíquica (Jung, 2013d). Jung (2013c) toma por metáfora o trajeto do sol para esclarecer o que compreendia sobre tal processo. O sol nasce brando acordando a natureza, e paulatinamente vai subindo até estar à pino ao meiodia, esta é a parte da metáfora que faz alusão à primeira parte da vida. Aqui estão incluídas, de modo geral, a fase do nascimento, infância, adolescência e fase adulta. Quando o sol se encontra no mais alto grau de sua expressão, o ser humano se situa na crise da meia idade, ou metanoia. Em seguida, o sol inicia sua descida, abrandando seu calor, até morrer no crepúsculo. Esta etapa contém a fase adulta mais amadurecida, a velhice e a morte (2013c).

No quadro da Psicologia Analítica o desenvolvimento da psique é ponto central, inclusive é tratado como um processo que se mantém a despeito do que acontece com o 
corpo em si. Ponto importante é que, para esta linha teórica, a psique se mantém em desenvolvimento mesmo quando o corpo é acometido pelo envelhecimento, por doenças, acidentes etc. A psique opera de outra forma, mesmo pertencendo a um corpo repleto de limitações, podendo continuar seu desenvolvimento constante e até ascendente (von Franz, 1995).

Jung empenhou esforços para compreender o desenvolvimento psíquico na primeira etapa do desenvolvimento humano estudando sonhos de crianças. A partir desta pesquisa, ele pode observar que os germes ou potencial da individuação já estariam presentes na infância. De acordo com Jung, o germe da personalidade já existe, mas ela só será conhecida a partir das situações vivenciadas (Jung, 2013d). Nos sonhos arquetípicos de crianças, ainda na primeira infância, é possível averiguar um padrão que será desenvolvido durante a vida. Com o passar do tempo e da vivência cotidiana passará aos poucos e arduamente ao desenvolvimento deste potencial (von Franz , 1980).

Qualquer discussão que se coloque na perspectiva da Psicologia Analítica a respeito do desenvolvimento da personalidade e, de modo especial, da personalidade da criança - deve começar assumindo o fato de que o que vem primeiro é o inconsciente, e que só depois é que surge a consciência. A personalidade como um todo e o seu centro diretor, o Self, existem antes de o ego tomar forma e desenvolver-se como centro da consciência; as leis que regem o desenvolvimento do ego e da consciência estão subordinadas ao inconsciente e à personalidade como um todo, que é representado pelo Self.(Neumann, 1995, p. 10)

A psique na primeira infância se encontra aberta ao mundo, é idêntica e indiferenciada dele. Nesta fase não existem ambivalências, tampouco experiências polarizadas: percepção de frio/quente, escuro/claro, bom/ruim etc. Segundo Neumann (2014), as experiências são circulares, eternas e autocontidas, não existindo começo e fim. A psique da criança é contida na Uroborus, imagem relacionada a cobra que morde o próprio rabo. Nesta fase, o ventre e os braços da mãe (ou adulto afetivamente responsável) maternam a criança, não apenas em sua dimensão pessoal, mas também pelo reino materno primordial. Aqui a criança não sabe definir quem é a mãe, mas sente-se contida, se existe um colo caloroso para se integrar.

Exatamente da mesma forma que o desenvolvimento geral do corpo da criança depende da alimentação fornecida pela mãe, assim também o desenvolvimento de sua psique depende da alimentação psíquica proporcionada pela figura materna. Nesse contexto, a relação primal propicia à criança quatro tipos essenciais de experiência. Enquanto mãe e filho ainda formam uma identidade indiferenciada, a relação primal funciona para a criança como possibilidade de relacionamento com seu próprio corpo, com seu Self, com o "tu" e com o mundo, tudo ao mesmo tempo. A relação primal é a base ontogenética da experiência de estar-no-próprio-corpo, de estar-com-um Self, de estar-unido, de estar-no-mundo. (Neumann, 1995, p 25) 
O ego do bebê não está formado, e sua vivência é experienciada a partir do próprio corpo na unidade mãe-filho, sendo o self a própria mãe. O self como centro da psique realiza a ligação entre o ego ainda em formação e o inconsciente (Jung, 2013a, 2013c, 2013d, 2013e). A relação com a mãe é imprescindível nos primeiros meses, quando o núcleo do ego, presente desde o princípio inicia seu desenvolvimento. Jung ressalta o fato de que a criança, na primeira etapa de desenvolvimento, está como um barco à deriva em alto mar, e é vulnerável às questões, conscientes e inconscientes dos pais ou responsáveis, porém são as questões inconscientes as que mais a atingem. $\mathrm{O}$ ego irá paulatinamente adquirir unidade a partir de suas experiências. No início, o ser humano não sabe quem é. Aos poucos, por meio das experiências, é que dá os primeiros passos em direção à construção da personalidade. É importante pontuar que a personalidade nunca cessa sua construção, já que ela está vinculada ao processo de composição e diferenciação do indivíduo. Desenvolver a personalidade está, portanto, vinculado ao processo de individuação, que será realizado até o último momento de vida do indivíduo, como dito anteriormente.

Para Jung o desenvolvimento do ego e da personalidade são processos trabalhosos, e o "eu" nascerá gradativamente com o contato com o ambiente externo. A personalidade é composta por aspectos universais (estrutura comum a todos os seres humanos), e particulares (experiências individuais, subjetivas). De acordo com Neumann (2014), a cada estágio do desenvolvimento humano existe uma variação de arquétipos, símbolos, deuses e mitos dominantes, como será observado a seguir. Após esta primeira fase, quando a psique do bebê ainda se encontra simbolicamente na Uroboros, no todo autocontido, o ego nascente inicia um paulatino contato com os desconfortos da realidade, tornando-se mais consciente das polaridades, das ambivalências de suas experiências, agora ele começa a sentir a dicotomia do prazer-dor, quente-frio etc.

Esse mundo experimentado por um ego humano prestes a despertar é o mundo do matriarcado de J.J. Bachofen, com a suas deusas da maternidade e do destino. A mãe devoradora e malvada e a mãe doadora e bondosa são dois aspectos da grande Deusa Mãe urobórica que reina nesse nível psíquico.

A evidente ambivalência do arquétipo, a sua bilateralidade, condiciona também uma atitude ambivalente do ego diante do arquétipo em cujo poder se encontra. (Neumann, 2014, pp. 46-47)

Nesse sentido o ego que inicia sua alvorada experimenta impotência, sentindo-se indefeso perante o oceano primal. O processo de diferenciação do ego envolve conflito: a exaustão em permanecer vígil (devido a fragilidade da consciência do ego) passa a ser tolerada e inicia a percepção dos opostos pela psique. 
A supremacia do mundo dos objetos e do mundo do inconsciente é uma experiência que tem de ser aceita. Por isso, o medo é um fenômeno normal na psicologia da criança. Embora diminua à medida que a consciência se fortalece, ele forma, porém, um impulso transpessoal para o desenvolvimento da consciência (Neumann, 2014, p.48).

O medo, segundo o autor, não está apenas na origem do ego, mas no desenvolvimento da consciência, da cultura, artes, religião, que fazem um esforço em identificar e superá-lo, num movimento importante que ultrapassa o que é pessoal, ambiental. Há uma tensão que não se pode impedir nos processos de desenvolvimento e individuação. Tanto em um quanto em outro, forças opostas e complementares serão mobilizadas a fim de se conquistar o equilíbrio.

Para o indivíduo se desenvolver, é necessário a ele aprender os padrões coletivos e adaptar-se. A criança, para construir uma vida pessoal, necessita "deixar projetada no mundo uma grande parte de sua psique e adaptar-se 'ao mínimo necessário de normas coletivas"” (Fordham, 1994, p. 18), nesse sentido, o ego se desenvolve para que a psique tenha condições de relacionar-se tanto com as demandas internas quanto externas. Fordham faz um contraponto: a criança não tem condições de avaliar a cada pequeno passo o que é ou não aceito socialmente, ela tem muito a aprender e não pode ainda abstrair com profundidade. Estar totalmente imerso na consciência coletiva, contribui para a diminuição da própria expressão criativa. Por mais que as convenções sejam necessárias para a coletividade, “"a vida criativa sempre se encontra fora das convenções’ (Jung, 1981, p. 178) e, por isso, a criatividade não é considerada um empreendimento popular" (Vilhena, 2009, pp.33-34). Diante do oposto, temos que a individuação e o início da vida têm metas opostas.

De acordo com Jung (2013c), nesta fase a memória, a cognição e os processos de aprendizagem iniciam o seu desenvolvimento. A memória não existe da maneira como conhecemos. Apesar de a criança absorver e interagir com o mundo externo, ainda não há continuidade da consciência, pois os fragmentos de consciência são intercalados com períodos de inconsciência. A memória somente passa a existir de fato quando a criança começa a dizer e a perceber o próprio "eu”. Os fragmentos vão sendo agrupados, e a consciência emerge, como afirma Jung, "como uma nova ilha aflora sobre a superfície do mar". (Jung, 2013a, pp.60-61)

Lidar com o mundo interno e externo passa a ser um desafio para a criança. Neumann acentua a importância que o ambiente tem no processo de desenvolvimento da personalidade. Não só a mãe-ambiente, mas a comunidade, a religião da comunidade e os 
aspectos culturais impactam na psique da mãe, dos membros da família e assim também no processo de individuação da criança em desenvolvimento.

A relação primal da criança com a mãe é mais do que uma relação primária, pois graças a essa relação, antes mesmo do seu "verdadeiro" nascimento, que ocorre quando tem por volta de um ano de idade, a criança vai sendo moldada pela cultura humana, uma vez que a mãe vive imersa num coletivo cultural, cujos valores e linguagem influenciam, inconscientemente, mas de modo efetivo, o desenvolvimento da criança. A atitude do coletivo em relação à criança, ao seu sexo, à sua individualidade e ao seu desenvolvimento, pode ser uma questão de vida ou de morte. $\mathrm{O}$ fato de ser menino ou menina, ou gêmeos, a aparência física da criança ou as circunstâncias do seu nascimento, se avaliados negativamente pelo coletivo, demonstra-se tão desastroso para o futuro da mesma quanto ser portador de uma deformidade física ou de uma deficiência mental. (Neumann, 1995, pp. 9-10)

A partir da experiência com o mundo exterior, o ser humano passa, por uma necessidade inata, a diferenciar-se dessa base inconsciente. Porém, para diferenciar-se, precisa se apoiar na psique coletiva. O sujeito nasce em um contexto pré-existente que possui regras, convenções, códigos e uma ética. Ao chegar à segunda infância, a exposição aos outros ambientes, como, por exemplo, o escolar, tem-se um outro passo no processo de desenvolvimento.

Ao chegar à idade escolar, a criança começa a fase de estruturação do seu ego e de adaptação ao mundo exterior. Essa fase traz em geral um bom número de choques e de embates dolorosos. Ao mesmo tempo, algumas crianças nessa época começam a sentirse muito diferentes das outras, e esse sentimento de singularidade acarreta uma certa tristeza, que faz parte da solidão de muitos jovens. As imperfeições do mundo e o mal que existe dentro e fora de nós, tornam-se problemas conscientes; a criança precisa enfrentar impulsos interiores prementes (e ainda não compreendidos), além das exigências do mundo exterior. Se o desenvolvimento da consciência for perturbado no seu desabrochar natural, ela, para escapar das suas dificuldades externas e internas, isolase em uma 'fortaleza' íntima. (von Franz, 2008, p.218)

Para a continuação do desenvolvimento, a criança precisa se maturar, para entrar na fase da adolescência e, enfim, na fase adulta. Sob o ponto de vista do eixo ego-self, Whitmont (1995) pontua que na infância a identidade total representada pelo amálgama ego-self (ainda não diferenciada), inicia seu processo de desintegração. A interação entre ambiente e potenciais arquetípicos paulatinamente produzem uma primeira personalidade real. Nesta fase, a criança percebe o meio e as pessoas em seu entorno como poderes que podem oprimir/ameaçar, já que o ego se relaciona com essas entidades, tendo-as como sendo mágicas e, mais tarde, mitológicas. No próximo estágio, que está relacionado com a fase da vida média ou adulta, a separação entre ego e self é consolidada. Aqui Whitmont afirma que: "O único poder reconhecido é o do ego - e isso é expresso no ditado popular 'querer é poder'”' (Whitmont, 1995, p. 236). 
Nesse sentido, temos que, durante a infância, adolescência, e fase adulta, o ego trabalha muito para diferenciar o que é próprio. No entanto, a força do contexto social é bastante representativa, vide que muitas escolhas são feitas a partir do que é socialmente aceitável e não do que realmente se deseja. Este processo, contudo, é importante, pois, segundo Vilhena (2009), é justamente esta adaptação que possibilita que o indivíduo se integre ao grupo social. Diante do exposto tem-se que, para Jung, na primeira metade da vida, há um grande esforço em existir e se estruturar, mas também há uma busca para a adequação social.

Na adolescência, Neumann (2014) afirma que, apesar de ter havido o nascimento do ego e a consumação de certa autonomia, o ego adolescente ainda enfrenta simbolicamente a soberania da Uroborus, transformada no poder da Grande Mãe que acalenta, mas pode seduzir, castrar, matar. De acordo com o autor, é nessa etapa do desenvolvimento que a consciência percebe mais apuradamente os próprios processos, numa autoconsciência emergindo. O ego reflexivo sabe agora que é o centro da consciência, esta experiência proporciona a consolidação efetiva de um sistema psíquico autônomo. Contudo o ego ainda possui muitas fragilidades e enfrenta combates importantes com o arquétipo operante da Grande Mãe. O adolescente nesta etapa não tem uma personalidade estabelecida nem um destino individual, seu destino ainda é coletivo vivendo apenas uma existência ritual. Libertar-se da condição urobórica ritualisticamente equivalerá à aquisição da consciência.

Simbolicamente, aos poucos, após travar a luta pela autoconsciência com os aspectos terríveis e violentos com essa Grande Mãe (bruxa, amante, castradora), o (a) jovem torna-se individual, e passa a ter a possibilidade de construir um destino pessoal. Nesta etapa, é utilizada a referência da jornada do herói para trazer à tona a complexidade e o esforço da psique em individuar-se da urobórus. É importante dizer que a “jornada do herói" no homem e na mulher é equivalente, sendo este termo utilizado para referir-se ao processo de desenvolvimento do ego em busca do self: "O final da puberdade é marcado pela luta bem-sucedida do herói, como atestam os ritos de iniciação dessa fase" (Neumann, 2014, p. 83). A puberdade é considerada então uma iniciação que deverá ser vivenciada. Esta passagem promove então a dissolução definitiva da fase urobórica, a separação dos Pais Primordiais e a solidificação efetiva da consciência do ego.

Numa palavra: a primeira tarefa do herói consiste em retirar-se da cena mundana dos efeitos secundários e iniciar uma jornada pelas regiões causais da psique, onde residem efetivamente as dificuldades, para torná-las claras, erradicá-las em favor de si mesmo (isto é, combater os demônios infantis de sua cultura local) e penetrar no domínio da 
experiência e da assimilação, diretas e sem distorções, daquilo que C. G. Jung denominou 'imagens arquetípicas'. Esse é o processo conhecido na filosofia hindu e budista com viveka, a 'discriminação' [entre o verdadeiro e o falso] [sic]. (Campbell, 2007, p. 27)

Os elementos da jornada do herói são diversos, entretanto, de acordo com Campbell (2007), existe um modelo primordial, essencial. O primeiro impulso de consciência aparece sob a forma de uma ferida/sofrimento (Johnson , 1993). O contato com tal ferida é imprescindível para a autoconsciência, ou seja, para adolescer é necessário sair do mundo ingênuo e paradisíaco da infância, do coletivo, o que é extremamente doloroso. Tal perturbação terá reflexos no meio que o cerca, já que o adolescente se sente num limbo, atravessando suas fronteiras. A insegurança se dá pela fragilidade do ego. Nessa transição, o narcisismo (falso amor-próprio, autorreferência exagerada, depreciação do lugar de origem) e o "tédio da vida" (autodestruição, autodepreciação), são experiências importantes, assim o germe da independência começa a se desenvolver (Neumann, 2014).

Nesta fase, ego e consciência alcançam autonomia, e a personalidade total do homem será distinguida do mundo e do inconsciente. $\mathrm{O}$ processo de masculinização/feminilização é fundamental e é ingrediente imprescindível para a estruturação do ego. A tarefa agora é concentrar-se na sua diferenciação da natureza, do mundo e do inconsciente. O herói tem como característica uma natureza dual:

Por um lado, o herói, justamente por se desviar da norma humana, é tido pela humanidade, isto é, pelo aspecto coletivo, como herói e de origem divina. Por outro, a ideia da natureza dual ser a característica do herói nasce dele mesmo, da sua experiência em si. Uma vez ele é um homem como os outros, é terreno, mortal e coletivo; mas, ao lado disso, não só se sente estranho diante do coletivo, como também, no seu íntimo, experimenta algo que, apesar de fazer 'parte dele' e quase 'ser ele mesmo', só pode ser designado como estranho, incomum e divino. Nos estados de elevação, quando age, reconhece e realiza como herói, ele se sente como 'inspirado', como algo extraordinário ou como filho de uma divindade. Assim, o herói, através da sua diferença em relação aos outros, experimenta o seu progenitor suprapessoal como bastante diferente do seu pai pessoal terreno, cuja natureza coletiva e corporal compartilha. Desse ponto de vista, também podemos entender a duplicação da figura da mãe. (Neumann, 2014, p. 110)

Autoconsciência e masculinidade/feminilidade são palavras sinônimas quando estamos falando do despertar do ego. A luta contra o dragão em sua peripécia só pode ser compreendida a partir da compreensão e desenvolvimento desta masculinidade/feminilidade, que é diferente do estado paternal. $\mathrm{O}$ afastamento do mundo feminino-maternal deve ocorrer para que ele renasça. A figura do herói/heroína é considerada aquele que nasceu duas vezes:

Jung demonstrou que o incesto do herói implementa o seu renascimento, que apenas o duas vezes nascido é herói e que, inversamente, todo aquele que sofreu o duplo nascimento deve ser considerado herói. Não é apenas entre os primitivos que o 
renascimento é o objeto dos ritos de iniciação. Do mesmo modo que o iniciado nos mistérios, todo gnóstico, brâmane indiano e cristão batizado é um homem renascido. Porque, ao submeter-se ao incesto heroico, penetrando no inconsciente devorador, a maneira de ser do ego é transformada e ele renasce como 'o outro'. (Neumann, 2014, p.117)

A luta contra o dragão tem um significado transpessoal, representando uma luta sagrada que tem como objetivo a conquista de uma gratificação especial. Em busca do tesouro, a guerra acontece entre os opostos (pais primordiais), que poderá, se for bemsucedida, libertar o ego dos poderes da uroborus. O tesouro pode ser representado por diversas facetas: a busca da cativa, o elixir da vida (Santo Graal), instrumentos mágicos, ou seja, algo precioso (símbolos de algo que não tem a ver com valor material) que é difícil de ser obtido. Este prêmio a ser alcançado tem caráter sagrado. O incesto representado com a pequena penetração que mata os aspectos masculinos e femininos da uroborus pode ser considerado, como pontua Neumann, a justaposição de fatores transpessoais e, também, personalistas.

O indivíduo, assim, ingressa na fase adulta, momento em que a personalidade se constitui de fato. Aqui existe a diferenciação dos conteúdos sombrios, mas também há agora a possibilidade de integração. Esse movimento revela um amadurecimento da psique rumo à tentativa de integração, ao caminho da inteireza. O importante neste momento é ter a noção de que somente quando o indivíduo estiver maduro ele poderá se contrapor ao meio em que vive e ter discernimento e posse de suas posições. De acordo com Fordham (1994), tal situação seria diferente na fase da infância, já que a criança, por ter a necessidade de se adaptar ao coletivo, não pode realizar estas dinâmicas tal como um adulto.

Contudo, é nessa fase que o ser humano, de modo geral (até a crise da meia idade), procura atingir objetivos, aprende uma profissão, preocupa-se em ser bem sucedido, trabalha, casa-se, tem filhos, e busca essencialmente integrar-se ao meio em que vive, respondendo com muitos esforços às expectativas sociais do momento histórico em que vive.

De acordo com Johnson (1993), para seguir seu desenvolvimento, o jovem adulto, como dito anteriormente, precisa entrar em contato com a ferida interna que não solucionou: "É necessário que o homem aceite olhar seu lado inocente, tolo, adolescente, para conseguir curar-se. Só o nosso tolo interior pode tocar a ferida do Rei Pescador" (p. 25). O autor, ao analisar o mito da busca do Santo Graal, refere-se à Parsifal, moço 
simples, inocente, oriundo de um lugar sem prestígio que precisará se desenvolver para alcançar a busca da cura do Rei do Castelo do Graal.

Este mito abarca o desenvolvimento da fase adolescente à fase da metanoia. Nele o herói deve deixar o "Jardim do Éden”, representado pelo mundo materno, confortável e nutridor, para realizar o seu chamado, ou seja, sair da uroborus, desenvolver o ego com ações alinhadas às manifestações simbólicas do self que é a meta do processo. Quando falamos em “jornada do herói” em Psicologia Analítica, não estamos fazendo nenhuma restrição de gênero, o herói é a metáfora, símbolo que representa o ego, independente se o indivíduo é um homem ou uma mulher.

Realizados os devidos esclarecimentos, sigo agora apresentando os próximos passos do desenvolvimento desta fase da vida. Em termos gerais, o desenvolvimento do mito do herói envolve uma caminhada de busca do masculino/feminino a partir de um ímpeto de estar junto aos cinco cavaleiros que Parsifal avistou passando pelas terras onde vivia com sua mãe, aprender a ser um fidalgo e um guerreiro com um padrinho que encontrara no meio da jornada e a lidar com suas imperfeições e as consequências de seus ímpetos. Outro aspecto é que Parsifal deve lidar com o feminino representado pelo complexo materno, pelo arquétipo materno, com a mãe natural, com a donzela (ou mulher) de carne e osso, com a donzela interior representada pela própria anima e, por fim, com a donzela tenebrosa por quem será humilhado a fim de retomar o seu caminho, sua missão de vida.

A donzela tenebrosa aparece na metanoia, momento em que, em geral, o sujeito alcançou o sucesso exterior, mas se sente fracassado e vivendo uma vida sem sentido. É preciso estar com esse aspecto da psique, ouvindo suas acusações, para que esses conteúdos sombrios possam trazer evolução ao processo. Neste momento da vida, o sujeito começa a se lembrar do que valia a pena antes da correria para servir ao ego, e é impelido a buscar na sua introspecção o ouro que está escondido. O Graal serve ao Rei do Graal na mesma proporção que a vida serve ao Self, ou mesmo Deus para os cristãos, algo maior que o próprio indivíduo.

Jung fala do processo da vida como sendo a recolocação do centro de gravidade do ego para o Self. Ele vê isso como o trabalho de toda uma vida e o centro de todo o significado para o esforço humano. Quando Parsifal aprende que ele não é o centro do Universo nem do seu pequenino reino -, fica livre da alienação e, por fim, o Graal deixa de ser vedado a ele. Agora pode entrar e sair do castelo pelo resto de sua vida, quando quiser. Nunca mais será um estranho nele. (Johnson, 1993 , p.115)

O Rei do Graal é nossa centelha divina, representação do self pessoal. Quando o indivíduo entende que deve servir a algo maior, inicia a cumprir seu objetivo. Se o 
indivíduo compreende que deve servir a algo maior e ao self, terá a vivência de transcendência. A partir da metanoia, o objetivo é outro, a orientação muda e passa-se à busca do si mesmo, da individuação. Há um rebaixamento da escuta das vozes sociais, coletivas, e o indivíduo passa a ser orientado pelo self que o impele a uma postura gradativamente mais honesta em busca de realizar uma personalidade mais ampla). O self é o verdadeiro centro da psique, matriz da estrutura psíquica, centro orientador da vida, um guia, um caminho que aponta para a realização do si mesmo (Whitmont, 1995).

Aqui, a partir do "sol à pino", no processo da metanoia há uma mudança substancial na psique humana. Ego e self deverão integrar-se, não como na infância, de modo inconsciente, mas trabalhando em um encontro consciente. De acordo com Whitmont, após o meio-dia da vida, inaugura-se o estágio do "retorno". Essa fase não pode ser levada a cabo se não houver um ego suficientemente forte para encarar o self. Por este motivo é que muitos anos foram utilizados para tal amadurecimento. Hollis (2015) explica que, quando se atinge a metanoia, o que ele chama de "passagem do meio", inaugura-se um importante rito de passagem. Esse momento é uma grande oportunidade, mesmo que por vezes dolorosa, de busca da originalidade (Hollis, 2015).

A reestruturação não é racional e o objetivo é a ampliação do potencial da personalidade. Nesta etapa, o ego passa a perder a voz de comando para que a psique ouça com mais atenção às mensagens do self que, por sua vez, é constituído pelo inconsciente coletivo e pelo potencial individual que será desenvolvido e constituído como personalidade. Nessa travessia há maior consciência entre o que o mundo espera de nós e o que nós somos de fato, tornando clara, inclusive, a percepção de como o nosso ego acredita ser (Jaffé, 1980). De acordo com von Franz (2008) o self dá sinais que orientam o melhor caminho para a autorrealização. Contudo, é um trabalho hercúleo, mas necessário. Como dito anteriormente, o self é tanto o representante da totalidade quanto meta da vida. Esta entidade transpessoal, como mencionou Whitmont (1991) , irá exigir sua autoconcretização, da melhor maneira possível visto que o ambiente, com suas oportunidades e limitações, fazem parte da construção como um todo, influenciando, dificultando e/ou facilitando.

Como dito anteriormente, para Jung, a individuação é o conceito central de sua teoria, tomada como diretriz para o seu método de tratamento (Jung, 2013e). Para o autor, individuação significa tornar-se um ser único, na medida em que por 'individualidade' entendermos nossa singularidade mais íntima, última e incomparável, significando 
também que nos tornamos o nosso próprio si mesmo. Podemos, pois traduzir ‘individuação' como 'tornar-se si mesmo'.

A individuação . . . significa precisamente a realização melhor e mais completa das qualidades coletivas do ser humano; é a consideração adequada e não o esquecimento das peculiaridades individuais, o fator determinante de um melhor rendimento social ...

Cada rosto humano tem um nariz, dois olhos etc., mas tais fatores universais são variáveis e é esta variabilidade que possibilita as peculiaridades individuais. A individuação, portanto, só pode significar um processo de desenvolvimento psicológico que faculte a realização das qualidades individuais dadas, em outras palavras, é um processo mediante o qual um homem torna-se o ser único que de fato é. E nada tem a ver com individualismo e egoísmo. (Jung, 2013e, pp. 63-64)

É importante tratar das questões inconscientes, já que, de acordo com Jung, os sujeitos que buscarem progredir na busca da realização do si mesmo inconsciente trará inevitavelmente à consciência os conteúdos do inconsciente pessoal, ampliando sua personalidade. Tal ampliação está relacionada ao autoconhecimento que integra conteúdos inconscientes como desejos, lembranças, planos, tendências, mas que geralmente se afiguram como desagradáveis às regras sociais e que, por isso, foram reprimidos. A partir da análise e principalmente no trabalho com os sonhos, temáticas essenciais são trazidas e, nesse processo de articulação entre consciente e inconsciente na busca do que realmente se é - pode-se humanizar o indivíduo, pois ele percebe que é constituído pelo que está na luz, mas também o que está na sombra (Jung, 2013c, 2013e).

É necessário citar nesse momento, mesmo que brevemente, as instâncias psíquicas denominadas por Jung por anima e animus. Jung descreve que a anima e o animus tem papel fundamental compondo no homem a totalidade das qualidades psíquicas femininas inconscientes, e o equivalente na mulher.

Como estamos aqui diante de um homem e de uma mulher, o que está sendo projetado só pode ser a parte feminina da personalidade do homem, ou seja, sua anima. Da mesma forma, a mulher só pode estar projetando o seu aspecto masculino. O que se obtém só pode estar projetando o seu aspecto masculino. (Jung, 2013k, p. 104)

O autor trata da questão da projeção, destacando que não existe acaso nas escolhas de parceiros e parceiras afetivos e/ou sexuais, e destaca a necessidade de serem trazidos para a consciência estes aspectos por meio da reflexão acerca destas instâncias. Jung, acrescido do comentário de von Franz, exemplifica que uma pessoa (possivelmente heterossexual), ao escolher um parceiro do sexo oposto, pode estar realizando sua escolha a partir da projeção de sua anima/animus, e alerta sobre a necessidade de trabalhar o autoconhecimento para não buscar nesta parceria uma projeção de sua anima/animus (o que pode ser desastroso) em vez de procurar uma relação de alteridade com uma outra pessoa: 
O casamento com a anima equivale psicologicamente a uma completa identidade da consciência com o inconsciente. Uma vez que um tal estado só é possível em caso de total ausência de autoconhecimento psicológico, ele é necessariamente mais ou menos primitivo, isto é, a relação com a mulher consiste essencialmente apenas numa projeção da anima. (Jung, 2013k, pp.109-110)

Ao mesmo tempo, quando refletimos sobre nós mesmos, sobre nossas reações aos outros e sobre a reação deles a nós, temos a chance de nos conhecer melhor. Quando uma mulher se entende com seu animus, quando ela reflete sobre as influências disso em sua vida, o animus se afoga nessas reflexões, enquanto ela mesma se salva do afogamento. (von Franz, 2010, p. 42)

Estas instâncias possibilitam que o ego dialogue com o inconsciente. Mais importante do que onde se projeta a anima do homem ou o animus da mulher é entender que são instâncias psíquicas que irão possibilitar que o ego faça um contato com o inconsciente, seja nos sonhos, nas técnicas expressivas e que os símbolos que advém do inconsciente são guias que nos levam para a compreensão dos processos internos ${ }^{11}$.

Diante do exposto é possível compreender a necessidade de tratar das questões advindas do inconsciente, integrando aspectos que foram reprimidos durante o processo de desenvolvimento do indivíduo, bem como promovendo a ampliação e a reflexão profunda de outras instâncias psíquicas, conforme dito anteriormente. Esse processo utiliza-se da expressão dos símbolos que emergem do inconsciente, sendo de certa forma um acerto ao leito de Procusto, na qual certas partes que foram amputadas outrora pela intolerância humana e pelas castradoras regras sociais poderiam ser reintegradas ao seu portador. Acontece que são muitas as partes que são complexamente necessárias para se recompor para que o ser humano esteja novamente inteiro. Nesse sentido, o processo de individuação segue até o último suspiro, num trabalho cheio de esforço e potência criativa.

Jung destaca outro ponto importante no desenvolvimento humano que nos serve agora para continuar ampliando a compreensão sobre a relação do ser humano com a morte: "na hora secreta do meio-dia da vida se inverte a parábola e nasce a morte" (Jung, 20131, p. 364). Com essa frase Jung anuncia que a partir da metanoia, haverá um contato cada vez maior com a questão da morte, pois pensamentos, sentimentos, sonhos, vivências com perdas irão ocorrer com mais frequência. O processo de individuação torna-se cada vez mais intenso e somente os indivíduos que entram em contato com as

\footnotetext{
${ }^{11}$ De acordo com C. A. Serbena (comunicação pessoal, 26 de março de 2021) é importante ressaltar que atualmente há um questionamento sobre os conceitos de anima/animus no sentido de retirar o seu "essencialismo "e focar no seu aspecto simbólico. Basicamente Jung não tem a diferenciação entre sexo e gênero, contudo outros autores tentam ampliar esta questão como por exemplo Whitmont que subistitui anima e animus por Yin e Yang que existem no homem e na mulher.
} 
questões da própria morte é que se mantêm vivos. Jung afirma que não querer morrer é o mesmo que não querer viver, já que a vida passa a estar muito íntima com as questões da morte, e alerta que se ainda há vida, por mais tênue que seja, o indivíduo deve agarrar-se a toda possibilidade de conscientização do si mesmo (Jung, 2003, p. 44).

Contudo, como tratado ainda na introdução, Jaffé (1980) denuncia que o ser humano na contemporaneidade, em geral, chega despreparado perante a morte. Talvez por apresentar um déficit de fé religiosa, já que as religiões é que deveriam preparar o indivíduo para a morte, considerando que as religiões é que se ocupam das questões da morte, da alma e do além vida. Jung afirma que o final da vida é um momento precioso e de inigualável beleza, pois leva o sujeito a aproximar-se mais intimamente de sua essência (Jung, 2001). Individuar-se é um processo que pode preparar para a morte (Jaffé, 1980).

Jung afirma que existem perigos se houver negligência na alienação do si mesmo e que, na saúde, o processo se desenvolve plenamente, não sem trabalho e esforço, como dito anteriormente. Sendo assim, para Jung, há riscos se não houver atenção a esse processo. Nesse sentido, Gambini (2005) aponta que não ser o que realmente se é representa:

Esse é o pior de todos os lutos, a pior das saudades, saudade daquilo que ainda não se é, saudade daquilo que se pode ser, mas a covardia impede. Esse é o luto fatal. . . Nossa tarefa mais premente, segundo entende a psicologia junguiana, é que nos tornemos plenamente aquilo que esboçadamente somos. É o desafio de abrigar a vida por inteiro justamente por sabê-la finita, perigosa, frágil e imprevisível, lembrando sempre que o tempo tudo apagará. (Gambini, 2005, pp. 143-144)

O ser humano tem uma força teleológica que o impulsiona ao desenvolvimento, e esse processo energético deve ser cumprido ao longo da vida de modo que, no final, ele seja o mais original possível (Jung, 2013c). Aqui é importante assinalar que existem processos patológicos. Jung percebe que alguns neuróticos gostariam de se manter na infância, juventude, negando o processo de amadurecimento.

\begin{abstract}
A fuga da vida não nos liberta da lei do envelhecimento e da morte. O neurótico que procura livrar-se da necessidade da vida nada ganha e apenas se impõe o fardo de uma velhice e morte precoces, que devem ser particularmente cruéis diante da falta de conteúdo e de sentido de sua vida. Se negarmos à libido uma vida que avança num fluxo constante, que conhece e quer o perigo e o declínio final, então ela tomará outro rumo e descerá para as próprias profundezas, cavando seu caminho até a antiga ideia da imortalidade de toda vida, a nostalgia do renascimento (Jung, 2013g, p. 465).
\end{abstract}

Para o autor, a segunda etapa da vida tem um sentido importante para a espécie, e não é apenas um apêndice lamentável de vida. Esta má impressão da velhice ocorre em certas culturas porque há uma inversão de valores. A morte tem impactos diversos na vida de um jovem e de um velho. Para o jovem existe um futuro, uma meta, e é esperado que 
ele deseje projetar-se neste sentido. Porém, se o jovem apresentar alguma variação, envolvendo-se de medo tanto do mundo quanto da vida, pode ser considerado como tendo um desenvolvimento patológico, neurótico (Jung, 2013c). O autor considera que existem jovens que sentem medo da vida, assim como idosos que sentem medo da morte, e percebeu em sua carreira uma grande incidência da relação: medo da vida, quando jovem, e medo da morte, quando velho. Para Jung (2013c) "De fato, é tão neurótico não se orientar, na velhice, para a morte como um fim, quanto reprimir, na juventude, fantasias que se ocupam com o futuro" (pp. 367-368).

Conforme envelhece, o ser humano tem mais contato com as imagens interiores e passa a refletir sobre o caminho trilhado. Os velhos também sonham com estas imagens e memórias, o que prova que a psique continua trabalhando e seguindo o caminho teleológico. Em casos extremos, alguns indivíduos se prendem a memórias de acontecimentos exteriores, fixando sua atenção no exterior, e não no caminho íntimo que deveria estar atento nesta etapa da vida. Jung afirma que existem processos e características que devem ser trabalhados em todo o percurso do desenvolvimento humano.

Os velhos têm um maior número de imagens do passado, e também pensamentos de futuro, o que inclui o tema morte. Contudo, Jung pondera que o medo do desconhecido, do sofrimento, da morte que se aproxima faz parte de um desenvolvimento normal. Olhar para a finitude não é uma tarefa fácil e, por mais certo de que a morte irá chegar, existe o medo, por parte do ego, da aniquilação. É por isto que há uma proximidade das especulações místicas, e a religação em algo maior e a fé são tão importantes para dar sustentação emocional.

As imagens de morte surgem nos sonhos de pacientes que se encontram na segunda etapa da vida. Os símbolos, de acordo com Whitmont (1995), sugerem que desse modo, o ego retornaria à sua identidade original com o self. "A existência é simbolicamente vivenciada como um mistério além da própria pessoa, além da capacidade do ego para o entendimento racional, além das pessoas e objetos, como um ser transpessoal que só pode ser compreendido simbolicamente" (Whitmont, 1995, pp. 235-236).

Dessa forma, encerro o subitem com uma breve apresentação da noção do desenvolvimento psíquico humano e do caminho teleológico que a psique percorre no processo de individuação. Durante toda a vida, o indivíduo irá experienciar perdas, situações difíceis, agregadoras, tanto individual quanto coletivamente (em família ou em 
grupos). Em cada fase do desenvolvimento, a psique irá reagir e integrar os aprendizados de modo diferente. No caso da presença de uma morte anunciada, o mesmo ocorrerá. Cada familiar, dentro de seu processo de desenvolvimento, irá lidar a partir dos recursos que possui com a ameaça da morte. Estas experiências podem modificar permanentemente a perspectiva perante a vida e, também, promover o encontro criativo com o si mesmo. Aqui o psicólogo deverá estar atento, oferecendo técnica e presença para que os membros do grupo familiar possam vivenciar este ritual de passagem profundo e transcendente. Além desta perspectiva, é importante trazer o desenvolvimento humano para poder olhar a pluralidade da família enlutada que está em atendimento no domicílio. Este viés é apresentado para auxiliar na reflexão do grupo e seus processos psíquicos, já que cada membro da família pode estar em uma das fases do desenvolvimento humano. Olhar para estas nuances enriquece a compreensão do fenômeno por parte do psicólogo e o auxilia na escolha das técnicas mais adequadas.

\subsubsection{Contribuições de Jung para a compreensão do enlutamento}

A morte é um acontecimento que não passa desapercebido. Ela ou sua ameaça trazem impactos de diversos graus, seja no indivíduo que vai morrer, seja em seu entorno. A força deste fenômeno é de uma magnitude tão marcante que não a percebemos apenas no caso de morte real, mas também em acontecimentos que nos fazem sentir a alma estilhaçar, seja numa traição, em uma injustiça que profundamente oprime, na perda de um ideal, de um amor e também na chegada do diagnóstico de uma doença grave. Todos estes casos geram, em graus variados, sintomas de luto (Bromberg, 1997; Gambini, 2005; Parkes, 1998).

Vários autores clássicos deixaram em seu legado um material significativo para auxiliar na construção de novos diálogos sobre o tema, seja na Filosofia, na Antropologia, História. Na Psicologia, Jung é um deles. Nesta etapa, irei me dedicar às contribuições de Jung para a compreensão do processo de luto e da relação do ser humano com a morte. Em primeiro lugar, serão abordados os aspectos do luto de si mesmo e o luto dos sobreviventes, ou seja, aqui serão tratados aspectos do luto de quem sofre a ameaça da morte e a vivência da perda de uma pessoa próxima e significativa. Será tratada a dimensão intra e interpsíquica, bem como as características deste tipo de perda. Em seguida, tratarei da morte sob a perspectiva simbólica. Aqui será apresentado o modo como Jung tratava da questão da morte tanto na dimensão individual quanto coletiva. Por 
fim, serão apresentadas algumas formas de manejo que a Psicologia Analítica tem disponível para os indivíduos que vivenciam um processo de enlutamento.

Jung foi um autor nada linear e, para se chegar ao resultado que será apresentado a seguir, foi necessário realizar uma vasta pesquisa em sua obra. A partir dos índices gerais (onomástico e analítico) realizou-se a leitura dos livros das obras compiladas e de alguns outros trabalhos do autor que apresentavam discussões sobre a temática. Registrei tudo o que Jung relatava sobre a morte, indiscriminadamente. Quando percebi certa redundância no material, as buscas puderam ser encerradas. $O$ passo seguinte foi a leitura do material compilado e o agrupamento dos conteúdos em núcleos convergentes. A seguir, serão apresentados os núcleos encontrados na seguinte ordem: em primeiro lugar como Jung entende o processo de luto dos sobreviventes (aqui acrescentarei o luto de si para enriquecer o constructo apresentado) e, em seguida, como o tema morte é tratado em seu trabalho, primeiro dando enfoque na perspectiva simbólica da morte, e depois no processo terapêutico.

\subsubsection{Aspectos do luto de si e da perda do outro afetivamente vinculado/outro significativo}

A Psicologia, como campo privilegiado do estudo das relações humanas, deve, de acordo com Gambini (2005), se esforçar para auxiliar na compreensão e na criação de modelos de intervenção que possam auxiliar o enfrentamento de pessoas frente a um sofrimento causado por morte. Independente da escola teórica, esta área do conhecimento deve trazer para o centro das discussões tal dimensão, seja ela a "morte na imaginação, a morte como interlocutora, como companheira em nossas fantasias" (p. 137), para integrar tal dimensão que é inerente à própria vida e que foi repelida em nome da tecnologia e da razão. O Homo sapiens sapiens, segundo Gambini (2005) e Callia (2005), há cerca de 60.000 anos, começou a enterrar os mortos, ação nunca antes praticada por outro animal. A pintura dos corpos e a preparação do sepultamento estimulou os arqueólogos a pensarem que aí se deu uma mudança cognitiva e social importante na espécie. Tais práticas podem ser consideradas marcas do nascimento da religião e da arte, sinalizando uma maior sofisticação com relação à "vida em sociedade, a linguagem, a simbolização e a eficiência técnica para lidar com o meio ambiente. . Portanto, o contato com a morte foi fundante para o nascimento da consciência" (Gambini, 2005, pp. 138-139). Nesse sentido, segundo Callia (2005), a percepção da morte promoveu o advento da consciência 
como parte integrante da estrutura psíquica. Este foi um processo importante, pois, segundo o autor, a psique primitiva, a partir da percepção do fenômeno, passou a se abrir vagarosamente tomando contato com a finitude e com o simbólico. Nasce assim a necessidade de enterrar criteriosamente os mortos e de ritualizar tal passagem. Nesse sentido, a morte ocupou "uma posição básica na existência da humanidade . . . revelando os primórdios de ideologias religiosas e a preocupação com o depois do morrer" (Callia, 2005, pp. 8-9).

Desde então se pode dizer que a relação do ser humano com a vida e com a morte pode ser entendida como uma construção coletiva que sofreu inúmeras modificações, transformando-se ao longo da História (Franco, 2002). A compreensão da morte e do luto são reflexos de seu tempo e do respectivo contexto cultural vivenciado. Dessa forma, a relação com a morte sofreu uma revolução silenciosa, pois podemos averiguar inúmeras modificações no que se refere à atitude do ser humano diante deste fenômeno, como averiguado na introdução com os vários tipos de relação com a morte: "morte domada", "morte interditada", "morte anunciada" etc. (Ariès, 1981; Franco, 2002). Nesse sentido, o luto e a forma de se lidar com a perda também sofreu modificações importantes.

Para Gambini (2005), a morte "é o último elemento a ser reinserido na consciência coletiva no mesmo nível de compreensão de outrora e conforme as urgentes necessidades da psique e da inteligência contemporâneas" (pp. 137-138). O autor questiona o fato de a morte, mesmo sendo parte fundamental dos processos psíquicos ter sido rechaçada e terminantemente reprimida na cultura contemporânea. De acordo com o autor, esse movimento não acontece nas culturas antigas, tradicionais como, por exemplo, na cultura indígena e africana, pois é mantido o processo ritualístico em sua profundidade até os dias atuais. Na ocasião de uma morte são reafirmadas as matrizes culturais, do sagrado, dos mitos, da reorganização social e humana. A resposta está relacionada ao impacto gerado pela Primeira e Segunda Guerras Mundiais, que deixaram marcas profundas no ocidente (Ariès, 1981; Franco, 2002), inclusive influenciaram certamente na construção do pensamento dos autores que vivenciaram a dor e o caos advindos desta experiência.

Jung (2006) nasceu no século XIX, anteriormente às grandes guerras mundiais, e teve uma vida tocada pelas questões relativas à morte desde tenra idade até seu último dia de vida, aos 86 anos. Segundo Coelho (2005), Jung considerava que

o inconsciente coletivo equivale à terra dos mortos, dos ancestrais, o além-túmulo. $\mathrm{O}$ encontro com o inconsciente coletivo é vivido como uma descida, a ideia de profundidade. É a morte deste mundo e a entrada em outro mundo. Corresponde ao termo 'nekyia' dos gregos, a viagem ao mundo dos mortos. (p. 164) 
De acordo com Hillman e Shamdasani (2015), Jung chamava de "lamento dos mortos" toda uma herança deixada pelos ancestrais e que afetaria diretamente cada um de nós. Jung convida a repensar a psicologia, pois as demandas que são respondidas hoje, têm como origem perguntas e angústias dos antepassados. Este enfoque pode ser considerado algo supra-humano, que dá ênfase à ideia de que estamos na própria História, fazendo parte de um todo, de um coletivo que, por um lado, gera perguntas e auxilia na formação de respostas.

Jung acreditava que todos os humanos precisariam de um mito de morte que pudesse funcionar como um balizador da existência, para que a vida não fosse percorrida com superficialidade e desproteção (Jung, 2006; Oliveira, 2005). O autor olhou o luto dos sobreviventes de uma maneira peculiar, e bem alinhada à sua teoria. De acordo com Jaffé (1980), importante colaboradora de Jung, o autor construiu estes conceitos a partir de suas concepções pessoais, de suas experiências e da rica bagagem técnica, literária e vivencial que possuía. Em seu trabalho autoral sobre a morte, ele não se preocupou em fundamentar-se a partir de "provas científicas" cartesianas e positivistas.

Para o autor, em se tratando do tema morte, existem infinitas e contraditórias formas de pensar, já que são plurais os olhares individuais e coletivos para a questão. As verdades coexistem e devem ser legitimadas como, por exemplo, a visão de mundo, vida e morte de um indivíduo orientado pela religião zen budista e que vive no Tibet se comparado a outro sujeito que vive em Londres e que segue os preceitos do luteranismo. Nesse sentido, o que é individual e o que é coletivo se entrecruzam, produzem caminhos e subjetividades que são importantes para a construção da fé e da maneira de ser e estar no mundo.

Não se pode deixar de observar, portanto, a influência do contexto sociocultural dos indivíduos enlutados, pois estas marcas trazem nuances diversas para a relação do ser humano com a morte. Callia (2005) apresenta uma faceta desta questão, como, por exemplo, o quadro a partir do qual o ocidental contemporâneo se posiciona perante o processo vida-morte-vida:

A cultura ocidental está possuída pela busca do que a psicologia analítica chama de 'arquétipo do Puer Eternus', ou seja, 'o eternamente jovem' que se distancia cada vez mais do seu complementar arquétipo, o Senex, o velho, dificultando as vivências simbólicas do envelhecimento e preparação para a morte ... O apego excessivo à vida $\mathrm{e}$ a negação da morte deixam o homem solitário e desprotegido diante da sua ilusória fantasia de poder, que sucumbe perante o irracional da sua finitude. A desvalorização do mito da morte, fruto de uma cultura moderna e dissociada, baseada na razão e na tecnologia, deixa o homem atual distanciado dos movimentos arquetípicos da transformação e do confronto com a morte. (Callia, 2005, p. 13) 
Como citado por Gambini (2005), o fenômeno da morte e seus desdobramentos podem, de acordo com Jung, ser compreendidos sob dois pontos de vista: "pode ter a voz serena da sabedoria ou o visgo do encosto obstrutor que nos empurra para a beira do abismo, travando tanto a caminhada como a própria vida" (Gambini, 2005, p. 140). Por meio da análise de duas cartas escritas por Jung - uma endereçada à Dra. Kristine Mann, em 1945, e outra ao Padre Victor White, em 1946, respectivamente - Jaffé (1980) traz uma experiência de Jung já com setenta anos. O contexto dessas cartas está relacionado ao fato de Jung ter sido acometido por uma doença grave e, perante uma morte anunciada, atravessou um processo difícil. Seguem os trechos das cartas de Jung apontados por Jaffé em seu livro.

Trecho da carta endereçada à Dra. Kristine Mann, em 1945:

O difícil é apenas isso: desprender-se do corpo, ficar nu e vazio do mundo e do livrearbítrio. Quando se consegue abrir mão do furioso desejo de viver, quando se tem a impressão de cair na neblina insondável, é então que começa a verdadeira vida, implicando tudo aquilo que viemos fazer, e que nunca alcançamos. É algo indescritível, de tão grande! (Jung, 1945 citado por Jaffé,1980, p. 13).

Trecho da carta endereçada ao Padre Victor White, em 1946:

... "o aspecto mortis", é de uma incrível solidão, quando se é privado de todas as coisas na presença de Deus. A própria totalidade é impiedosamente colocada à prova. (Jung, 1946 citado por Jaffé,1980, p. 13)

Para Jaffé (1980), “ao considerá-la do ponto de vista psicológico, a morte é o 'desapego' total, a anulação do Eu e do mundo consciente no interior de um não-Eu desconhecido e sombrio" (p.13). Segundo Gambini (2005), a morte, como companheira sábia, é a maior propulsora do processo de individuação. Não há como um processo energético iniciado ser revertido, a partir do momento em que ele começa, não voltará mais para o seu princípio. Este movimento tem como característica a orientação unívoca para um objetivo, que é impreterivelmente para o repouso. Assim, a vida é compreendida como um processo que ocorre entre dois repousos. Sendo assim, o grande objetivo da vida não é o seu ápice, momento em que o ser humano em geral atinge o amadurecimento biológico. O propósito final da vida é o retorno ao vale, onde tudo teve início. Logo, “o grande objetivo, meta da vida é a morte" (Jung, 20131, p.365).

Ao analisar as imagens advindas de sonhos de pessoas que estavam em processo tanatológico, conscientes ou não, von Franz (1995) pode observar que a morte do corpo não coincidiria com a morte da psique, como citado no início do presente item. A autora confirmou os preceitos da Psicologia Analítica que consideram que do inconsciente emergem imagens da invencibilidade da alma, ou seja, a característica do "self enquanto 
núcleo indestrutível da personalidade" (p. 80). Mais à frente trarei alguns outros aspectos das imagens e símbolos que emergiram de pacientes, tanto de Jung quanto von Franz, que estavam em processos de morrência.

Além dos aspectos do luto de si, Jung também trata do luto daqueles que ficaram e/ou dos que vivenciam a dor de uma perda literal ou simbólica ${ }^{12}$. O enlutamento pertence àquela categoria que Jung denominou "“dores da alma', sem ser necessariamente uma neurose" (Wahba, 2005, p. 175). Segundo Wahba (2005), a literatura analítica tem grande riqueza com relação à amplificação de símbolos, compreensão dos símbolos relacionados à dor da perda, e sobre a integração do eixo ego-self o que auxilia sensivelmente a compreensão e ressignificação da morte. Contudo, existem poucas produções acerca do processo de luto em si.

Para a autora, o material existente não aproxima de fato da compreensão da dor, estando mais preocupado com as projeções e com o processo de individuação, além de fixar o olhar nos aspectos filosóficos e em demonstrar "a extensão da psique humana que transcende tempo e espaço" (Wahba, 2005, p. 181).

... pouco é escrito sobre a perda de um outro significativo, que mantinha com o sujeito uma relação de alteridade, com um mínimo de projeções envolvidas. $\mathrm{O}$ conceito de elaboração não atinge plenamente o fenômeno de uma perda substancial, na qual não somente deixa de existir quem recebe o afeto - investimento de libido - como se deixa de viver uma rica conexão, única em particularidades provindas da pessoa que morreu. A distinção entre luto normal e patológico, com suas etapas descritas para a elaboração considerada natural, é muito diagramática e não responde à complexidade da vivência de dor decorrente da ausência de um outro que tem especial valor na relação de troca, afeto, estímulo emocional e intelectual. Somente o entendimento do fenômeno do vazio e da ausência, sem subterfúgios, pode, para algumas pessoas, ajudar a continuar a vida e a refazer significados. (Wahba, 2005, p. 176)

A produção de Jung contém insumos preciosos para compor um modelo de luto, mesmo não tendo sido produzido e sistematizado com tal objetivo. A seguir apresentarei uma parte deste material e, paralelamente, irei aproximá-lo de certos aspectos do modelo de fases de Bowlby e Kubler-Ross e do Modelo do Processo Dual citados no início desta tese com o intuito de promover um diálogo que auxilie na sistematização aqui pretendida sobre o luto antecipatório a partir do quadro da Psicologia Analítica.

Como dito anteriormente, o luto antecipatório vivido pelo adoecimento grave de um ente querido é caracterizado por ser um processo de adaptação frente a uma morte anunciada. De acordo com a literatura especializada, este fenômeno é composto por

\footnotetext{
${ }^{12}$ Lembrando que todo símbolo é duplo e paradoxal, dessa forma a morte como símbolo também terá duplo significado e vivência.
} 
reorganizações em várias dimensões da vida, como a psicológica, cognitiva, social, espiritual, econômica dentre outras. No que tange a dimensão psíquica, é observado um processo no qual o familiar cuidador passa por uma série de reações como, por exemplo, momentos em que sente seu humor embotado numa tristeza profunda, mas também experimenta momentos de raiva, alegria, de desorganização e reorganização, e de sentimentos ambivalentes, como o desejo que o ente adoecido sobreviva mais um tempo e pouco tempo depois sinta o desejo de que este termine sua jornada, pois já não é suportável tanto sofrimento.

De acordo com Jung (2013c), a morte é um fenômeno implacável, inflexível e contundente. Para o autor, o fenômeno tem o efeito de colocar o ser humano em contato com a finitude e com o real sentido da vida. Sua ação pode impactar de diversos modos e intensidades, e os sobreviventes podem entrar em contato com sentimentos extremos, ambíguos e oscilar entre eles continuamente. Sendo assim, o enlutado pode experimentar dor psicológica intensa, sentimentos de terror e, ao mesmo tempo, sentimentos de uma alegria calorosa. A oscilação desses extremos origina-se porque a morte pode ser percebida a partir de dois pontos de vista: do eu e da alma.

Sob o ponto de vista do eu, ou seja, do ego, Jung (2006) afirma que a morte provoca o contato com um acontecimento de ordem catastrófica, brutal e aniquiladora. $\mathrm{O}$ ego sente-se fora de controle e entra em contato com a finitude, o que gera dor psicológica e sentimento de impotência, torpor, fúria, desorganização, ansiedade, desespero. A consciência de que todas as possibilidades de contato com a pessoa que morreu são interrompidas gera também nos sobreviventes reações de isolamento, negação, silêncio. Estes resultados também foram encontrados por Bowlby ${ }^{13}$ (1984a) e Kübler-Ross ${ }^{14}$ (1998b). Tais sentimentos colorem a psique com nuances gélidas, pois se percebe que todas as pontes entre o ente que partiu e o ego foram quebradas. Em geral, este rompimento traz impacto na fé do indivíduo e também no sentimento de esperança e justiça (Jung, 2006). Do ponto de vista do ego, existe a vivência de dor psicológica frente a sensação de vazio e da impotência profunda.

No entanto, o enlutado, pode também vivenciar outros sentimentos. No processo de elaboração da perda, alterna a orientação de seus pensamentos observando-a sob o

\footnotetext{
${ }^{13}$ Para Bowlby (1984a), as fases do luto (pós-óbito) são as seguintes: entorpecimento, anseio e busca da pessoa perdida, desorganização e desespero e, por fim, reorganização.

${ }_{14}$ Para Kübler-Ross (1998b) as cinco fases do processo de luto (antecipatório e/ou pós-óbito) são as seguintes: negação ou isolamento, raiva, barganha, depressão ou interiorização e aceitação.
} 
ponto de vista da alma, ou do self. Neste novo enquadre, o enlutado percebe que a pessoa que morreu uniu-se novamente a algo maior, resgatou a inteireza, e pode ter retornado ao que Jung (2006) chamou de "mistério de união", o que permite sentimentos de paz, alegria e confiança. Em muitas culturas, esta alegria é observada, como nas festas dos mortos no México - em que são realizados festejos populares sob os túmulos; e em tumbas etruscas e sarcófagos gregos, onde eram representados banquetes e danças que simbolizavam o aspecto festivo da morte, como comenta o autor. Quando este sentimento de paz genuína tem relação com uma percepção íntima de que tudo o que pode ser cumprido na vida foi cumprido, um estado permanente, calmo e aparentemente sem sofrimento, é estabelecido. É como se a psique enfim encontrasse um lugar, um sentido profundo, e não se debatesse mais nas tensões do desejo de controle do ego, ou seja, o indivíduo enlutado pode ter alcançado um nível de consciência no qual se compreende os processos de vida-mortevida sem sofrimentos ou rompantes de desejo. O mesmo pode ser verificado quando o moribundo, em seu processo de enlutamento por si, alcança um estado de um certo desinteresse perante as vozes externas e um desdém (sem rompantes) das regras sociais. A alma humana, quando atinge este estado individuado, não está deprimida, mas esvaziada das tensões, substancialmente consciente do processo teleológico da vida. Este sentimento pode ter relação com a fase de aceitação que Kübler-Ross (1998) apontou em sua teoria, caracterizada como uma etapa em que o enlutado busca paz e silêncio.

A morte pode ser compreendida simbolicamente como uma companheira sábia que auxilia o desenvolvimento do si mesmo, tanto do paciente quanto dos familiares que cuidam dele. Contudo, este estado de paz e certa resignação frente aos ciclos da vida são alcançados (se são alcançados) depois de muito trabalho psicológico. O self, como núcleo indestrutível da alma, percebe a vida de uma maneira ampla, trazendo a percepção da invencibilidade da alma que transcende tempo e espaço, e estas características trazem uma nova perspectiva para a personalidade em desenvolvimento. Isso acontece tanto com o paciente quanto com os familiares.

A partir de Jung $(2006 ; 2013 c)$ podemos compreender que o enlutado vivencia de maneira oscilatória todos esses sentimentos. Nesse sentido, tal dinâmica pode favorecer o enfrentamento da nova realidade que se apresenta. Este movimento pode ser representado por uma costura, um alinhavo entre dois planos, sendo que a alternância auxilia na construção de significados sobre o luto e um processo de autoconhecimento, ora doloroso, ora em plenitude, ora sob o ponto de vista do ego, ora sob o ponto de vista do self e, sobretudo, nas integrações do eixo ego-self. 
Os pesquisadores do Modelo do Processo Dual (Stroebe \& Schut, 1999) também perceberam a importância da dinâmica dessa oscilação, salientando que a alternância dos estados que apresentarei a seguir teria a função regulatória do luto. Stroebe e Schut (1999) defendem que o luto desencadearia dois tipos distintos de estressores, a saber: estressores relacionados à perda e estressores relacionados à restauração. Vale destacar que, basicamente, são entendidos como estressores experiências que rompem a homeostase do indivíduo, ou seja, situações que interferem de modo importante em sua vida, desregulando a conservação e o equilíbrio antes existentes (Selye, 1965). Sendo assim, estressores mobilizam estratégias de enfrentamento, isto é, estimulam operações internas executadas com o intuito de viabilizar a adaptação a uma circunstância adversa (Antoniazzi, Dell'Aglio \& Bandeira, 1998).

Nesse sentido, o enfrentamento orientado para a perda englobaria o trabalho de luto intrapsíquico, a busca da pessoa perdida, a vivência da intrusão de luto, lidar com a quebra de ligação, dos laços, da deslocalização da pessoa falecida, bem como com a negação e a evitação das alterações de restauração. Já na orientação para a restauração, o enlutado estaria exposto à necessidade de reorganização da vida, entendida como estressor secundário e, assim, incluiria atender a necessidade de mudanças de vida, realização de novas tarefas/projetos, distração da dor, evitação da dor, e também ao desenvolvimento de novos papéis, estabelecimento de novas relações e, por fim, com a construção de nova identidade (Stroebe \& Schut, 2001a). A alternância entre essas orientações seria essencial para a construção de significados positivos sobre o luto, permitindo ao enlutado perceber que muito do passado continuaria importante para a vivência do presente e o planejamento do futuro (Mazorra, 2009).

Sob o quadro da Psicologia Analítica, podemos olhar o fenômeno do luto antecipatório como um processo de adaptações importantes no qual existe um movimento de oscilação entre a perspectiva do ego e a perspectiva do self. Esta oscilação entre as duas perspectivas são imprescindíveis para a regulação do luto, e também do desenvolvimento do eixo ego-self e no processo de individuação. Como já tratado anteriormente, o self, como centro da psique, irá realizar a ação reguladora da psique a fim de orientar a mesma em seu caminho teleológico. O trabalho do self é direcionado para o processo de individuação, processo árduo no qual escolhas serão realizadas e muitos confrontos estarão em voga. A vida externa pode trazer situações e tensões que influenciarão este processo e o self irá coordenar os processos psíquicos por meio do que Jung chamou de função transcendente direcionando a psique para sua autorrealização. 
Sob o ponto de vista do self, o indivíduo pode passar a assimilar a ação de cuidar como uma "missão", mas também como um obtuso estorvo. Nesta ação, o ego pode vislumbrar consciente ou não sobre a possibilidades de obter ganhos objetivos, subjetivos e ainda a possibilidade de reaver o vínculo com o ente adoecido. A forma como cada sujeito toma para si o cuidado enquanto ego e self podem ser infinitas. Importante, porém, é que, sendo aparentemente positivo ou negativo, é preciso estar atento aos comportamentos unilaterais e inflexíveis frente ao cuidado.

Em geral, quando o diagnóstico de uma doença crônico-degenerativa é dado, muito pouco se sabe sobre a doença, como cuidar do paciente durante a evolução do quadro e como será a interação com as mudanças de papel e os vários lutos que a situação impõem. Devido a pressão originada pela intrusão da nova e dolorosa realidade, é esperado que aspectos sombrios polarizem e invadam, e também é esperado que o complexo relativo a persona sofra influência. No decorrer do processo, haverá muitos aprendizados e, conforme a literatura especializada, uma nova identidade é consolidada (Gonzaga, 2012; Stroebe et al., 2017).

Como apontado anteriormente sob o ponto de vista da Psicologia Analítica, a perda apresenta-se como um agente impactante, e todo o sistema psiquico é atingido objetivamente. Cada indivíduo lida de uma forma com a nova realidade, podendo inclusive lançar mão de defesas como a própria negação. Sabendo que quando um fenômeno ocorre em um lugar na psique, o mesmo equivalentemente acontece em seu polo oposto. A ameaça de morte atinge o consciente e ela é patologicamente negada, no inconsciente esta energia será ativada. Na saúde, a energia do sistema psíquico flui variando na dinâmica entre as instâncias consciente e inconsciente. Mesmo em sujeitos saudáveis, que não tenham cindido, pode haver luto complicado. Este processo ocorre devido a um desequilíbrio e/ou bloqueio da energia psíquica ao lidar com o luto. Aproximando de Parkes (1998), que tratou do luto complicado em suas duas modalidades, luto inibido e luto crônico, temos que, no quadro da Psicologia Analítica, o luto complicado seria aquele no qual a energia psíquica não flui, mantem-se fixada e/ou em desequilíbrio.

Podemos entender que o luto inibido seria aquele luto vivenciado no modo progressivo, no qual o indivíduo teria uma postura negligente de seus processos internos. Os cuidados de uma pessoa adoecida por alguma doença crônico-degenerativa requer muitas mudanças na rotina, novos aprendizados e, em muitos momentos, o cuidador principal abre mão da própria vida, como apontado nos capítulos anteriores. Frente à 
adaptação do luto antecipatório, a energia psíquica fluiria do inconsciente para a consciência para atender as necessidades de adaptação ao meio externo, e o indivíduo passa a se dedicar intensamente aos cuidados do ente adoecido. $\mathrm{O}$ abandorar-se pelo outro pode ser entendido em muitos casos como uma interrupção do processo de individuação, já que a energia que poderia ser dedicada ao próprio caminho, ao desenvolvimento do si mesmo está sendo usada progressivamente nas adaptaçães do mundo externo. Nestes casos, o comportamento unilateral do ego pode causar sintomas neuróticos, adoecimento físico, dentre outros impactos, o que transforma o cuidador em um "paciente oculto" conforme apontado por Couto (2004). É claro que em parte dos casos o cuidar do outro coincide com o próprio desenvolvimento. Sendo assim, estar no papel de cuidador acaba por ampliar, potencializar e facilitar o processo de individuação.

Jung bem observou que, ao longo da vida, comportamentos opostos podem passar a serem apresentados, sendo a enantiodromia parte do processo de compensação energético. A compensação evoca processos de mudança efetiva (e muitas vezes antagônicas) na personalidade dos indivíduos. Pessoas com comportamentos x, ao serem expostas a situações de muita pressão, podem ter inconscientemente acionada a enantiodromia, mudando de perspectiva, atuando no comportamento oposto ao que era negado. No luto antecipatório como pode acontecer? A negação do ego acerca da gravidade do paciente pode ativar no inconsciente o princípio contrário fazendo ativar no inconsciente elementos de contato com a morte, como pode ser ilustrado por meio da distribuição da força quando acionamos um arco e flecha. A potência da força que gerará o tiro está associada à tensão colocada na corda, só que no sentido contrário, ou seja, quanto mais puxamos para trás, mais energia é empregada para que a flecha seja impulsionada para frente. Exemplo disso é o caso de Miss Miller, uma paciente que Jung atendeu em sua carreira e que será apresentado em outros detalhes no decorrer da tese. De acordo com Jung, a paciente mantinha uma posição unilateral de ego, vivendo fixamente em um "mundo cor-de-rosa". Quando Miss Miller buscou ajuda, estava insuportavelmente sendo bombardeada por imagens de morte e violência durante seu sono. Jung compreendeu que as imagens que emergiam violentamente de seus sonhos eram advindas do processo de compensação e autorregulação de sua estrutura psíquica, que tinha o intuito de levar a paciente ao esforço de integrar outros aspectos abandonando o comportamento unilateral e fixado em um mundo leviano e superficial. Na compreensão do caso de Miss Miller, Jung apresenta o drama de Cassius e Brutus, e fala da dramatização da morte: 
É fato conhecido que o ponto culminante da vida é representado pela simbólica da morte, pois o crescer-além-de-si-mesmo significa uma morte. Como ser infantil Miss Miller não pode tomar consciência da meta de sua vida, não pode estabelecer objetivos ou normas pelas quais se sente responsável. Por isso também ainda não está pronta para enfrentar o problema do amor, pois este exige consciência e responsabilidade, visão e previsão. É uma decisão para a vida, que termina com a morte. Amor e morte têm muito em comum. (Jung, 2013g, p. 341)

O contexto sócio-histórico-cultural tem forte influência no comportamento e na formação ética de maneira geral. Nesse sentido, existem ações, pensamentos, desejos que podem conviver na luz e outros que são enviados para a sombra por serem socialmente indesejáveis. A herança judaico-cristã mantem forte influência na designação da mulher enquanto cuidadora (Gonzaga, 2012), e na manutenção da ideia positiva do "bom samaritano". A parábola bíblica do "bom samaritano" pertencente ao Novo Testamento foi massivamente impregnada no senso comum convertendo em um dever ético e religioso a obrigação de cuidar com compaixão do "próximo" em todas as suas necessidades. Acontece que qualquer comportamento polarizado, esteriotipado, que tem por objetivo atender às expectativas sociais pode ser prejudicial para a saúde do sujeito.

No caso de um cuidador ou uma cuidadora ser guiado em sua rotina pela premissa de que está em missão samaritana com o ente adoecido, podemos compreender a partir de Jung que se aquele ignorar os seus aspectos internos, pode gerar em seu inconsciente uma força de sombra perigosa. Esta sombra pode emergir, trazendo o extremo oposto do comportamento unilatereal na tentativa de que exista uma integração daquilo que está sendo negligenciado. Como aconteceu no caso de Miss Miller, a ação de ignorar os processo internos e a falta de autodesenvolvimento gerou sintomas, inclusisve fatais.

O familiar que cuida pode ficar em situação vulnerável, gerando como resposta interna o adoecimento físico, social e/ou psicológico. Ou seja, quando a polaridade sombria de um complexo é ativada e o ego não tem força ou estrutura para integrá-la ou administrá-la, essa energia pode provocar patologias físicas, psicológicas e/ou sociais (Whitmont,1998). Tendências, desejos e o que foi negligenciado, por serem incompatíveis com a persona e/ou os padrões sociais, podem invadir o ego. O indivíduo tende a projetar suas características indesejáveis em outros ou a se deixar dominar pela sombra sem o perceber. Segundo Whitmont (1998), não existe ser humano sem sombra, ela é parte integral da natureza humana e não pode ser eliminada. O processo de luto antecipatório pode deflagrar a autonomia dos complexos constelados e invadir a personalidade de modo a trazer sofrimento e dificuldade na vivência das ambivalências que perpassam tal situação. 
Sob certos ângulos, a sombra pode também consistir de fatores coletivos que brotam de uma fonte situada fora da vida pessoal do indivíduo. Quando uma pessoa tenta ver a sua sombra, ela fica consciente (e muitas vezes envergonhada) das tendências e impulsos que nega existirem em si mesma, mas que consegue perfeitamente ver nos outros. . . (von Franz, 2008, p. 222).

Neste momento é importante trazer o material sombrio para a consciência, o que auxilia no enfraquecimento desta energia (sombria). Dessa forma, se o ego estiver fortalecido, a entrada dos conteúdos ocorre de modo mais organizado. Para tanto, é importante o suporte terapêutico para que os conteúdos não emerjam de modo avassalador. O esforço de integrar os conteúdos sombrios pode auxiliar os familiares no processo de luto antecipatório. Em muitos casos, é necessário o acompanhamento psicológico dessas famílias, pois, mesmo que o luto antecipatório e seu contexto provoque reações comuns às pessoas que o vivenciam, a jornada deve ser idiossincrática, possibilitando aprendizados, ressignificações que auxiliarão o processo de individuação.

Durante o desenvolvimento do indivíduo, as experiências de sua história são acumuladas de modo a constelarem os complexos. Nestes complexos são agrupados sentimentos, pensamentos, vivências positivas e negativas, recordações e imagens, apresentando uma configuração a partir da qual o indivíduo se posiciona, inclusive em momentos de enlutamento:

A experiência humana da angústia pode ser entendida a partir do ponto de vista dos complexos e da psicologia arquetípica em várias avaliações. [...] o caráter uniforme da lamentação, suas emoções típicas, os tipos de comportamentos e a evolução dessas emoções através de fases ou padrões sugerem que tais experências pessoais são influenciadas por temas arquetípicos comuns à experiência da humanidade. (Savage , p.25)

O trabalho de Savage (1989) acerca do luto por perda parental pode somar na reflexão proposta neste item. Quando a autora trata do processo de lamentação devido a perda de um filho, ela indica que o desenvolvimento do luto depende da experiência anterior que o indivíduo traz em sua solução. Aí não há apenas relação com outras experiências de morte, mas também com outras perdas, outras dores. A análise que a autora faz do processo de luto pós-óbito pode ser ampliado para o luto antecipatório, já que nestes casos as experiências passadas ao serem consteladas também influenciam a experiência atual, sendo esta relacionada ao luto anterior ou posterior ao óbito.

Savage (1989) traz a noção de que os arquétipos são predisposições ou mesmo balizadores da experiência humana, e que "a influência sobre a lamentação dá ênfase à necessidade psicológica de compreender o sentido da perda" (Savage, 1989, p.26). Experiências anteriores irão auxiliar neste enfrentamento como um todo, recrutadas como 
uma base de ação frente aos complexos constelados. Cada familiar irá reagir de uma forma, mas, de acordo com o que foi dito até o momento, existe uma influência arquetípica que torna comum a experiência de luto.

Por fim, a teoria de Jung acerca da natureza autônoma do complexo descreve a real experiência da lamentação. De modo semelhante aos efeitos comportamentais de um complexo constelado, o luto tem a capacidade de sobrepujar e de dominar a personalidade consciente, de tal modo que as pessoas enlutadas, pelo menos por uma época, ficam incapazes de se libertar de suas garras. Os efeitos perturbadores do luto continuam até que a perda possa ser assimilada emocionalmente, e resultam em uma nova distribuição da energia psíquica. ... A resolução do processo de lamentação demanda que a ampla extensão da perda e dos seus efeitos sobre a pessoa que sobrevive sejam tornados conscientes. Como afirma Jacobi, 'nenhum complexo pode ser resolvido a não ser que se enfrente o conflito que o produz, e isso requer coragem, força, e um ego que seja capaz de suportar o sofrimento'. Basicamente, toda pessoa se angustia de uma maneira pessoal e idiossincrática. Todavia, padrões comuns, de fato, surgem e revelam aspectos comuns na experiência da lamentação na sua forma habitual. (Savage, 1989, pp. 26-27)

De modo geral, o contexto aqui apresentado gera mudanças e influência nas estruturas psíquicas, como a persona, complexos e sombra. Explorando mais um pouco os aspectos relacionados ao "ser cuidador/cuidadora", podemos aproximá-lo do arquétipo do curador-ferido, mas também do arquétipo materno (Grande Mãe), do senex, do guerreiro e assim por diante. Trato dessa aproximação porque a vivência de sentimentos ambivalentes no cotidiano pode ativar os complexos impulsionando o psiquismo para processos de desenvolvimento. Este movimento funciona como um princípio ordenador, mobilizador. A deflagração de conteúdos relacionados a sofrimento, apenas indicam que um polo foi ativado e que outro, ligado à felicidade está atuando no outro extremo (Jung, 2013c, 2013i).

Há tantos arquétipos quantas situações típicas na vida. Intermináveis repetições imprimiram essas experiências na constituição psíquica, não sob a forma de imagens preenchidas de um conteúdo, mas precipuamente apenas formas sem conteúdo, representando a mera possibilidade de um determinado tipo de percepção e ação. Quando algo ocorre na vida que corresponde a um arquétipo, este é ativado e surge uma compulsão que se impõe a modo de uma reação instintiva contra toda a razão e vontade, ou produz um conflito de dimensões eventualmente patológicas, isto é, uma neurose. (Jung, 2013h, p. 57)

A precaução aqui é com relação aos conteúdos que são negados ou interditados, se não houver um olhar para o que está sendo comunicado pelo inconsciente, a psique pode agir de modo a paralisar, e invadir destrutivamente. Jung alerta que os complexos não implicam neurose, não são patológicos. Em caso de doenças crônico-degenerativas, que têm características específicas relacionadas ao tempo de evolução da doença, o processo pode impactar durante os anos de cuidado. 
A partir do diagnóstico, a família passa a viver um novo contexto tendo que se reorganizar, aprender novas habilidades para cuidar de um ente adoecido, lidar com a ameaça da morte presente. Aqui existe o confronto com a finitude, com o medo de ficar só, o receio de não conseguir cuidar (nem todos os familiares têm o treinamento necessário quando assumem o cuidado), medo de ser julgado pela família/sociedade, de não materializar planos de vida e, ao mesmo tempo, medo de perder o ente querido, e de falar sobre o tema morte, vivência de sentimento de culpa, inadequação e impotência, e o desejo de que a morte aconteça de fato. Ainda podem estar presentes sentimentos positivos, como se sentir potente e útil, estar próximo ao ente e reaver questões mal resolvidas do passado, encontrar no cuidado uma nova profissão, dentre outros (Gonzaga, 2012, 2015; Mazorra, 2009; Stroebe et al., 2001) . De acordo com os autores, este tipo de experiência pode gerar novas identidades, "a construção do papel de cuidador . . . demanda o manejo de uma matéria-prima bruta, sobretudo a disponibilidade interna, e um conjunto de operações complexas que irão transformá-lo e depurá-lo até que seja construída uma nova identidade.” (Gonzaga, 2015, p. 51).

Utilizando a lente da Psicóloga Analítica, pode-se pensar que todo o processo interfere positiva ou negativamente no processo de individuação dos familiares do ente adoecido. Jung define que este é um processo no qual o indivíduo se torna um ser único, tornando-se ele mesmo: “. . . na medida em que por 'individualidade' entendermos nossa singularidade mais íntima, última e incomparável, significando também que nos tornamos o nosso próprio si mesmo" (Jung, 2013e, p. 63).

Nessa jornada de cuidados diários, os familiares são confrontados com uma realidade diferente da que estavam acostumados antes do adoecimento do ente querido. A forma como cada familiar lida com a nova configuração (os novos aprendizados, novos sentimentos, além da relação mais aproximada da morte) pode auxiliar na aproximação desse "si mesmo", mas esta movimentação pode não ocorrer. O período relacionado ao luto antecipatório pode ser simbolizado, se me é permitido trazer essa imagem, pelo processo de preparar a terra para o plantio. Num primeiro momento, pode ser estranho e conflitante as duas imagens (plantio versus luto), por vezes opostos, já que o plantio se refere a vida e o cuidado nesses termos se aproxima da morte. Quando falamos de morte anunciada, podem vir muitas ampliações, como sentimentos negativos diversos, e lavrar terra, um trabalho de fé, de acreditar que, se o trabalho for realizado, faça chuva, faça sol, haverá vida. 
No entanto, quando há um chão fértil e/ou um bom suporte, o luto antecipatório pode trazer mais vida para todos que estão envolvidos no processo. De acordo com Arantes (2013), o processo de luto antecipatório carrega um poder de cura, de regeneração, uma oportunidade de amenizar o impacto do pós-óbito. Segundo a médica paliativista, a vida precisa valer a pena, o tempo não pode ser desperdiçado, cada minuto é importante. O suporte oferecido aos familiares deve ter o objetivo de ajudá-los a transcender a perda. Para Arantes, não se deve olhar somente a doença, visto que esta é irreversível. Contudo, a oportunidade de viver as relações com plenitude e afeto é certamente reversível.

No tempo de plantio, a terra, indefinidamente deverá ser arada, cuidada, tratada, pois o tempo da semeadura não permite blefes, terceirizações, falsas relações. É o próprio lavrador que deve se haver com a terra para que as sementes possam, no tempo certo, serem germinadas. De acordo com alguns estudos, no luto antecipatório, muitas questões são revolvidas, e os familiares se orientam para a perda (Gonzaga, 2012; Mazorra, 2009; Pine, 1986; Rando, 1986).

Como dito anteriormente, temos que no contexto de luto antecipatório, persona e sombra também são acionados durante o processo, o ego utiliza da persona para se apresentar socialmente. A persona, por ser um arquétipo carregado durante a vida de experiências e afetos, contém os atributos utilizados para nos relacionar com o mundo. Esta estrutura é diametralmente oposta à sombra, "que não é o todo da personalidade inconsciente: representa qualidades e atributos desconhecidos ou pouco conhecidos do ego - aspectos que pertencem sobretudo à esfera pessoal e que poderiam também ser conscientes." (von Franz, 2008, p. 222).

A persona é utilizada para proteção da psique, mas, por vezes, ela passa a ser obsoleta e, num nível mais grave, patológica. No processo de individuação pode ser necessária a mudança de papéis sociais, mudança de estilo de vida, enfim, a mudança no modo de ser no mundo. Acontece que nesse momento pode haver conflitos importantes entre o contexto e os recursos psíquicos (devido a comportamentos fixados em um dos pólos). O indivíduo precisa tornar consciente os aspectos pouco desenvolvidos, bem como possibilitar a integração de novas saídas (originadas do extremo oposto do conteúdo polarizado) a partir da ação da função transcendente.

O luto antecipatório é um contexto muito específico. Aqui temos o fato de que existe uma ameaça de morte. Esta realidade pode ser impactante e, em certos níveis, transformadora. Contudo, a forte vinculação com os papéis sociais representado pela 
rigidez da persona pode demonstrar uma defesa bem estruturada, pois entrar em contato com o adoecimento grave de um ente querido pode ser doloroso e, talvez, ameaçador, disruptivo devido a possibilidade da perda iminente. Neste processo, acolhemos as demandas emocionais e construímos junto aos familiares planos que poderiam flexibilizar aspectos carregados de rigidez para que possam experimentar (em doses homeopáticas) aos poucos à nova forma de se relacionar com a nova situação. Sob o ponto de vista junguiano, quando existem conflitos entre persona e sombra, certos conteúdos do inconsciente podem invadir. É pertinente dizer que as invasões sempre existirão, inclusive por motivos banais e cotidianos, como em uma simples divergência de um troco na padaria, mas, quando o motivo está relacionado a uma morte que se anuncia, o impacto é imensamente dilacerante:

Independentemente de fatores biológicos e ambientais, todo ser humano tem uma propensão psicológica para a destruição. Violência, crime, assassinato e crueldade são a sombra da alma humana..... A qualquer momento a autonomia da sombra pode emergir, como o Médico e o Monstro, ou vir aparecendo aos poucos em condições extremas, como no romance $\mathrm{O}$ senhor das moscas. . . . Uma vez que o ser humano tem uma sombra cuja profundidade chega ao nível coletivo . . . o comportamento humano é movido por essa força arquetípica. (Hillman, 1997, pp. 249-250)

Os aspectos sombrios do complexo ativado invadem a psique, subjugando a autonomia do ego. A invasão faz com que o ego enfraquecido tenha energia roubada pelos conteúdos invasores do complexo ativado. Dessa forma, o ego do indivíduo, nesta situação, acaba por perder força e se esvaindo de força e energia para seguir, tendo cada vez mais dificuldade em cuidar, atividade exaustiva por essência. Nesse sentido, os aspectos sombrios se expressam de diversas formas e intensidades.

Como apontado anteriormente, de acordo com a psicologia analítica todo ego tem uma sombra pessoal, um complexo que Jung nomeou por sombra e que tem um núcleo arquetípico. É a partir da sombra pessoal que a sombra coletiva encontra passagem. Todos os seres humanos têm uma predisposição, uma tendência para a sombra. Um bom holding realizado pelo psicólogo, ou mesmo pelo grupo terapêutico pode acolher, trazer ressignificação para o processo vivenciado.

Dessa forma, é preciso buscar a compreensão dos processos de luto, entender como ocorrem os processos afetivos originados com o rompimento por morte, o amadurecimento, a regressão da identidade, o desenvolvimento de novos papéis, mas também tratar a morte como companheira, como bem observou Gambini (2005). É preciso conversar com a morte, e só assim é que iremos reinseri-la no cotidiano, na alma. 
Ampliando essa discussão, podemos pensar que a morte pode ser uma companheira, tanto no luto pós-óbito quanto no luto antecipatório.

\subsubsection{Perspectiva simbólica: morte, sonhos e mitos}

Como já demonstrado, Jung considera a dimensão simbólica como base ontológica do funcionamento humano. Esta manifestação ocorre pela expressão de símbolos que podem emergir por meio de mitos, contos de fada, folclore, visões, sonhos etc. Neste subitem tratarei da perspectiva simbólica da morte tanto no que se refere aos sonhos, no campo do individual, quanto ao terreno mitológico, no campo coletivo.

Para esclarecer o conteúdo apresentado trarei um caso atendido por Jung e, em seguida, alguns exemplos de símbolos tratados numa importante compilação de sonhos realizada por von Franz (1995), apresentada em seu livro Os sonhos e a morte: uma interpretação junguiana. Na sequência, trarei as orientações de Jung sobre a importância dada aos mitos como balizadores no enfrentamento da morte e, para finalizar, apresentarei a perspectiva da morte como símbolo no âmbito mitológico pela ampliação feita por Jung de um trecho de um mito cristão e outro trecho de origem indígena $(2013 \mathrm{k}, 2013 \mathrm{~g})$.

Jung afirma que sua atenção extrema, enquanto terapeuta, está nos fantásticos mitos da alma. A partir de sua experiência clínica, Jung percebeu que nos sonhos de um certo tipo de pacientes, aqueles que morreram meio ao processo psicoterapêutico, emergiam símbolos relacionados à mudança de vida, ao renascimento, mudanças de localidade, viagens - de uma maneira bem específica. Jung concluiu que o processo tanatológico iniciaria anteriormente a morte em si, pois, a partir dos sonhos, a questão da morte emergia na própria sessão terapêutica. O que chamou sua a atenção é que esta questão não surgia como algo importante e urgente, mas como um percurso natural para a psique, e que para ela não havia um fim determinado, e sim uma continuação após a morte terrena. Ou seja, o autor concluiu que, na dinâmica psíquica, o self não se desespera frente ao terreno da morte, o que é diferente para o ego (Jung, 2013c).

Miss Miller foi uma paciente que vivenciou um profundo trabalho psicoterapêutico e foi a óbito enquanto ainda era acompanhada. Esteve com Jung em dois momentos da vida: em um primeiro momento, sentia-se muito perturbada com sonhos violentos de morte, como apontado anteriormente; em um segundo momento, mais consciente de seu processo, sonhava com símbolos mais amenos, como símbolos de renascimento. A paciente, em princípio, tinha uma visão unilateral de si, e não conseguia 
integrar partes de sua sombra e nem do seu processo de individuação, permanecia em uma posição infantil, o que pôde ser fatal. No caso desta paciente, o inconsciente passou a invadir as fronteiras da consciência, por meio de sonhos e de uma doença letal que foi desenvolvida (Jung, 2013g).

De modo geral, pode-se afirmar, a partir do quadro da Psicologia Analítica, que se o ego está paralisado, temendo a vida, os conteúdos do inconsciente podem invadir de forma arquetípica, trazendo à tona e com frequência símbolos que remetem a ameaça à integridade do corpo e o desejo de preservá-lo do processo de decomposição. No caso de Miss Miller, enquanto ela permanecia resistente ao contato com questões mais profundas, vivendo um "mundo cor-de-rosa" e superficial, o inconsciente compensava no momento do sono com sonhos que a invadiam com imagens perturbadoras, violentas e que remetiam à morte.

Jung considera que os símbolos têm a função de mediar, emergindo conteúdos que sinalizam o caminho que a psique deve se orientar. Acontece que o homem/mulher moderno relegou o simbólico (mitos, sonhos, fé) a um lugar inferior, desacreditado, em nome da ciência, o que empobreceu sua perspectiva e o diálogo com orientações ancestrais e com o inconsciente coletivo (Jung, 2006).

O racionalismo inaugurado com o Iluminismo é profundamente criticado por Jung, por perceber que o homem contemporâneo não sabe mais fabular e falar das questões profundas que o ligam com a algo maior:

O homem mítico reivindica certamente "algo além", mas o homem na sua responsabilidade científica não pode dar-lhe assentimento. Para a razão o fato de "mitologizar" . . . é uma especulação estéril, enquanto para o coração e a sensibilidade essa atividade é vital e salutar: confere à existência um brilho ao qual não se quereria renunciar. Nenhuma motivação seria suficiente, aliás, para justificar essa renúncia. (Jung, 2006, pp. 346-347)

Olhar para as mensagens do inconsciente torna-se imprescindível e vital em qualquer momento da vida. Não é simples ou fácil decifrar estas mensagens, já que no inconsciente os arquétipos não estão, de acordo com von Franz (1990), puros. Segundo a autora, um acaba por contaminar o outro, sendo na prática inseparáveis, atemporais e sem localização espacial definida. Quando o consciente olha para essas imagens, um tema é selecionado, "é como se colocasse uma lanterna acesa, e tudo depende de onde se coloca o facho de luz em primeiro lugar, pois de alguma forma, sempre se obtém todo o inconsciente coletivo" (von Franz 1990, p. 23).

O tratamento psicoterapêutico de Miss Miller precisou ser suspenso e, anos depois, ao retornar, a paciente se encontrava mais amadurecida, conseguindo 
compreender que também era constituída de forças além de sua consciência, e de que havia um chamado para o desenvolvimento psíquico. Mais integrada nesta segunda etapa, a paciente trazia a Jung sonhos com imagens mais brandas, mesmo estando adoecida e com uma morte anunciada. Este exemplo pode ilustrar que, mesmo existindo uma morte esperada por um agravamento do estado de saúde físico, a psique não a considera violenta, ou aniquiladora, pois os símbolos do renascimento faziam referência à morte como um processo esperado, natural da vida.

No processo de individuação da paciente citada, as facetas complementares "morte" e "vida" interagiram para a integração dos contrários. Para a conscientização daquilo que não estava integrado, e que era urgente para a realização potente e ampla de sua portadora, a função transcendente pôde auxiliar a dinâmica restituindo o sentido do desenvolvimento psíquico de Miss Miller.

Na psique, a morte, com suas diversas representações, pode aparecer como extinção, aniquilamento, negação e finalização (aspectos negativos bastante ressaltados na sociedade ocidental) e também como profunda e significativa transformação, revelação, renascimento, rito de passagem e mysterium coniunctions (Hillman, 1993; Welman; Faber, 1992).

Vida e morte representam a dualidade complementar do arquétipo regente da vida humana, ou seja, da individuação ... A interação dialética e dinâmica dessas duas facetas, opostas, compensatórias e complementares, mediante o mecanismo simbólico, possibilita a atuação da função transcendente que restitui a totalidade pela integração dos contrários no intuito de conduzir à realização da personalidade originária, potencial (Edinger, 1992; Jung, 1978).

Essa realização é decorrência da ativação do arquétipo da individuação no qual a pessoa é impulsionada a realizar plenamente as potencialidades inatas em direção ao seu centro íntimo (Self) e tornar-se si mesma, inteira, completa indivisível e distinta das outras pessoas. A busca é por sintonia com a própria essência do indivíduo, por meio de ações dirigidas para o desenvolvimento da personalidade. (Magalhães \& Serbena, 2011, pp. 56)

Nesse mesmo sentido, von Franz (1995) nos traz compilados e ampliados sonhos que dão ao leitor a ideia de como as imagens do inconsciente são apresentas quando o indivíduo está acerca da iminência da morte. Não se trata aqui de realizar um resumo do livro da autora, mas de compartilhar alguns pontos importantes para a Psicologia Analítica e a compreensão da perspectiva simbólica no processo de morte. Segundo a autora, seu objetivo não era de apresentar um tratamento para pacientes terminais, e sim dar ênfase a forma como a natureza nos prepara para a morte por meio dos sonhos. É preciso alertar novamente a necessidade de que os sonhos sejam interpretados corretamente, já que as imagens que aparecem nos sonhos podem surgir em diferentes contextos. Por se tratar também de um material universal, a autora utiliza material etnológico e alquímico em sua amplificação, posto que, de acordo com von Franz, a 
tradição alquímica produziu muito mais material sobre as questões da morte do que as religiões tradicionalmente constituídas.

Dessa forma, von Franz (1995) acompanhou inúmeras pessoas na clínica que estavam em seu caminho para a morte, conscientemente ou não. Ela utilizava a escuta simbólica, priorizando os sonhos e outras experiências que auxiliava o paciente em seu processo de morte. Para tal autora, a psique transcende o tempo e o espaço, e importa mais ao inconsciente o processo de individuação do que a morte em si. As imagens trazidas pelo inconsciente não são meras coincidências, elas devem ser acolhidas em sua simbologia a fim de auxiliar o processo de transformação e - por que não? - de preparação para a morte.

Von Franz traz a ideia de que Jung compreende a morte como um problema da ordem do limiar de percepção, entre vivos e mortos. Há uma completude entre estes dois mundos, sendo assim complementares. Nas palavras de Jung:

Esse espetáculo da velhice seria insuportável se não soubéssemos que nossa psique atinge uma região imune à mudança temporal e à limitação espacial. Nessa forma de ser nosso nascimento é uma morte, e nossa morte é um nascimento. Os pratos da balança se equilibram. (Jung, 1973, p. 569 citado por von Franz, 2005, p.178)

A seguir, irei apresentar somente alguns dos símbolos de sonhos tratados pela autora, encerrando com a apresentação de um caso. Von Franz compila os sonhos de morte que trazem imagens relacionadas a passagens escuras remetendo ao ato de nascer, e o estado de desalento, de profunda tristeza e falta de sentido como temas arquetípicos que aparecem em sonhos. Segundo von Franz (1995), Kübler-Ross também reconhece este movimento descrito como fase de depressão (ou interiorização), processo em que a pessoa que está à beira da morte se desliga do mundo externo: "Na minha opinião, sua finalidade é desligar do mundo exterior a consciência do moribundo, pois na depressão esse mundo é vivenciado como fútil, sem sentido, irreal" (von Franz, 1995, p.83).

A imagem da bola contida em outra maior é, portanto, uma bela representação da relação entre ego e Self.

Mas algo se perde com a morte. Além da cessação dos afetos, desejos e emoções, muito daquilo que chamamos "calor humano" também parece desaparecer. É possível às vezes observar esse aspecto em pessoas no processo de morte, as quais apresentam reações estranhamente "distantes" e "desligadas". (von Franz, 1995, p.133)

Em outro momento, a autora apresenta os símbolos da morte representados pela imagem do outro sinistro ou benevolente. Grosso modo, as imagens que surgem podem estar relacionadas com o divino (Jesus, anjos, Deus, Deuses etc.) e imagens sombrias (diabo, Hades, ladrão, presença que dá ao sonhador a sensação de medo, um animal, ou ainda figuras míticas associadas ao submundo); ou também pelo outro benevolente, por 
meio de figuras positivas, sendo esta presença agradável constituída por pessoas vivas ou mortas. De acordo com sua experiência, as figuras do outro sinistro surgem nos sonhos daqueles que não têm uma relação com a morte, ou não a espera. Nesse sentido, aqueles que têm pouca familiaridade com os aspectos obscuro ou sombrio do divino costumam apresentar nos sonhos a imagem relacionada ao sinistro.

$\mathrm{Na}$ verdade, é Deus, ou uma deusa, que traz a morte ao homem; quanto menos familiaridade ele tiver com esse lado sombrio do divino, mais negativo será o modo de vivenciá-lo. Todas as grandes ·religiões sempre souberam que vida e morte fazem parte do mesmo mistério divino que se oculta atrás da existência física do ser humano. (von Franz, 1995, p. 93)

Outro símbolo encontrado se refere à passagem pelo fogo e pela água. Von Franz faz menções sobre o fogo do purgatório para os cristãos, o lago para os egípcios e o simbolismo destas imagens em rituais. O símbolo do fogo, segundo a autora, tem como oposto a água, remetendo respectivamente a energia psíquica (força desconhecida que é manifestada nos impulsos, desejos, afetos) e aos "estados noturnos da alma" (von Franz, 1995, p. 106) (êxtase, sonho, transe), ao inconsciente coletivo. A imagem do sacrifício ou tratamento do corpo velho também é muito recorrente. De acordo com a autora: “. . . em linguagem psicológica, o corpo morto transforma-se numa imagem do inconsciente coletivo e, em seu aspecto de unidade, transforma-se no Self." (von Franz, 1995, p.116). Para encerrar este ponto, apresentarei um caso trazido pela autora:

Acometida por uma doença incurável, uma jovem, que inesperadamente veio a falecer durante uma intervenção cirúrgica, teve o seguinte sonho, antes da fatal operação:

'Eu me encontro à beira de um lago, junto com meu marido e alguns amigos. $\mathrm{O}$ lago é muito profundo e a água é clara, transparente, limpa e azul. De repente, vejo um pássaro preto no fundo do lago; ele está morto. Sinto um grande pesar e tenho vontade de mergulhar e salvá-lo. Não suporto a ideia de que esteja morto. Meu marido, com carinho, mas muito firme, intervém e me pede para não fazê-lo, porque, diz ele, está certo do jeito que está. Eu olho mais uma vez para o fundo do lago e vejo o olho do pássaro: é um diamante que brilha muito. Então eu acordo.'

O pássaro morto é, por certo, o extinto espírito vital do corpo que a sonhadora deve abandonar, para não ser contaminada pelos poderes de dissolução da morte. Ela deve livrar-se do corpo que está morrendo, mas ao mesmo tempo olha para o olho de diamante do pássaro. O diamante (de además, invencível) é uma variante alquímica do Self enquanto núcleo indestrutível da personalidade. (von Franz, 1995, p. 80)

O sonho apresentado por von Franz demonstra claramente a dinâmica de ego e self $e$ de outras estruturas da psique da paciente no momento anterior à morte. É possível verificar neste sonho que o processo de morrer não pode ser vivido de modo leviano, superficial, sob o ponto de vista do ego. Contudo, o self (indestrutível) se coloca no sonho do sonhador com o símbolo do diamante eterno para acercá-lo de que, se olharmos bem, a psique não se finda. Diante do que foi tratado até aqui, podemos compreender que os 
símbolos de morte advindos de sonhos, mitos etc. são importantes para trazer luz e ressignificações para o ser humano que está lidando com as questões da morte.

Para a Psicologia Analítica, o contato com o mundo mítico torna-se um balizador potente e fértil para se atravessar esta realidade. O mito é uma expressão simbólica do inconsciente e Jung dava muita importância aos seus aspectos, inclusive considerando salutar o contato com estes e em particular com o mito acerca da morte. Para o autor, o símbolo é uma ponte entre o inconsciente e a consciência:

O mito é o degrau intermediário inevitável entre o inconsciente e o consciente. Está estabelecido que o inconsciente sabe mais que o consciente, mas seu saber é de uma essência particular, de um saber eterno que, frequentemente, não tem nenhuma ligação com o "aqui" e o "agora" e não leva absolutamente em conta a linguagem que fala nosso intelecto. Somente quando damos às suas afirmações a oportunidade de "amplificar-se", ... é que este saber do inconsciente penetra no domínio de nossa compreensão, tornando possível a percepção de um novo aspecto. (Jung, 2006, pp. 358-359)

$\mathrm{O}$ inconsciente nos apresenta o mito de uma vida post-mortem através destas pontes. Como dito anteriormente, Jung não concebia a estas informações o valor de provas, mas lhes dava um valor de fundamental importância. Para o autor, estas servem para amplificações míticas que nos auxiliam nas experiências de vida. Em caso de não ocorrer a escuta dessas informações inconscientes, o ser humano pode estagnar na pobreza de uma leitura racional ou doutrinária. O indivíduo pode assim dizer "amém" para os dogmas, seja da religião ou da ciência, e empobrecer os sentidos e narrativas relacionados à sua experiência.

Nesse sentido, se dermos ênfase à perspectiva simbólica da morte e incluirmos os aspectos trazidos pelo inconsciente, poderemos sentir de certa forma amparados, mesmo estando em sofrimento. Entrar em contato com os conteúdos inconscientes fortalece a capacidade de associar, organizar, e ampliar sentidos, pois estes trazem elementos férteis àqueles que estiverem vagando pelos territórios sombrios e avassaladores da morte.

A razão não tem a capacidade de trazer acolhimento e explicação ao contato abissal com o fenômeno morte:

Uma questão categórica se apresenta à [humanidade], e não [temos] nenhuma obrigação de achar resposta para ela. Para esse fim, [devemos] ter um mito acerca da morte, pois a razão não [nos] revela senão o abismo escuro no qual estamos [submergindo]. Entretanto, o mito é capaz de conjurar para [nós] outras imagens, que são retratos providenciais e gratificantes da vida no território da morte. Se [acreditamos] nessas imagens, ou as acolhemos com certo grau de confiança, [estamos] igualmente certos ou errados, como alguém que nelas não acredita. Porém, enquanto [aquele] que se desespera marcha de encontro ao nada, o que depositou... fé no arquétipo segue as formas de vida, e vive diretamente para a [própria] morte. Ambos, para estar seguros, permanecem na incerteza, mas um deles vive contrariamente aos instintos, o outro, lado a lado com eles. (Jung, 1961citado por Savage, 1989, p. 8) 
Para Jung, tanto aqueles sujeitos que utilizam estes recursos quanto os que desacreditam estão no mesmo patamar. A diferença é que os primeiros têm mais chance de ressignificar o que lhes está acontecendo, enquanto os segundos poderão ter mais dificuldade. Ampliando este conceito, podemos compreender a fé, a religiosidade como uma vivência do processo mítico, já que as religiões se constroem como uma força suprahumana, que dá sentidos aos processos humanos que pela razão não é possível ter acesso. É por essa perspectiva que Jung vê os símbolos e, por isso, dá tanta importância aos mitos. Estes são projeções que o ser humano faz de situações de difícil lida e das quais não tem pleno controle, por exemplo, o nascimento, as paixões, a morte, e outros. Acreditando-se ou não, como projeções, os mitos têm um fim em si mesmo, funcionando como um farol orientador para os povos.

Guardadas as diferenças existentes entre mitos, conto de fadas, histórias folclóricas e outras expressões arquetípicas, von Franz (1990) esclarece que a partir dos mitos obtemos "as estruturas básicas da psique humana através da quantidade de material cultural” (p. 25). Nas palavras de Bolen (1990),

Os mitos e os contos de fada são expressões de arquétipos, como também muitas imagens e temas dos sonhos. A presença de padrões arquetípicos comuns em todos os povos constata as semelhanças nas mitologias de muitas culturas diferentes. Como padrões preexistentes, eles influenciam o modo como nós nos comportamos e como reagimos aos outros. (Bolen, 1990, pp. 37-38)

É interessante observar que nos contos de fadas, por exemplo, ao contrário das histórias tidas por von Franz como "sagas locais", o herói tem características estereotipadas, sendo uma figura abstrata, e não humano:

Pode-se usar a analogia de um cadáver, sendo o conto de fadas os ossos ou o esqueleto, a parte que não é destruída, pois ele é o núcleo básico e eterno de tudo. Ele reflete com mais simplicidade as estruturas arquetípicas básicas. (von Franz, 1990, p.32)

De acordo com von Franz (1990), os mitos são histórias arquetípicas compostas por conteúdos inconscientes e se originam em experiências individuais por meio de sonhos ou experiência de alucinações com o sujeito em vigília. A relação entre mito, história local e conto de fadas acontece da seguinte forma:

... quando uma história está enraizada em algum lugar, ela é uma saga local; e, quando ela vagueia como uma planta aquática sem raízes, adquire a característica abstrata de um conto de fada, e que se uma vez mais adquirir raízes torna-se uma saga local (von Franz, 1990, p. 32).

Mais adiante,

Para mim os contos de fada são como o mar, e as sagas e os mitos são como ondas desse mar; um conto surge como um mito, e depois afunda novamente para ser um conto de fada. Aqui novamente chegamos à mesma conclusão: os contos de fada espelham a 
estrutura mais simples, mas também a mais básica - o esqueleto - da psique. (von Franz, 1990, p. 33)

Diante do exposto, os mitos surgem a partir de situações que nos trazem um sentimento de confusão, impotência, descontrole, e não é de se espantar frente ao fato de que existem muitos deles relacionados ao tema morte em diversas culturas. Aqui serão apresentados dois exemplos em que a morte é compreendida como um símbolo, um exemplo foi destacado da mitologia judaico-cristã e outro da mitologia indígena.

Jung aprofundou-se na pesquisa dos textos sagrados tendo o cuidado de avaliá-los na língua original, e trabalhou o símbolo da morte a partir do contexto da imolação de Jesus a partir do Novo Testamento. A cena a que se refere é o momento em que a "mãe da vida", Virgem Maria, beija a "mãe da morte", a Cruz, referindo-se ao momento em que Maria se reconcilia com a Morte, aceitando assim, o processo que o filho está atravessando (Jung, 2013g). De acordo com Jung, este mito representa também a travessia do homem inconsciente, totalmente identificado com a mãe (ou a Uroburus) para tornarse consciente de si. O beijo entre "mãe da vida" e a "mãe da morte", simboliza a grande travessia, repleta de dor, aceitação, rompimentos e amadurecimento, análogos ao processo de morrência. Segundo o autor, esta simbologia também aparece em outras culturas, como na mitologia egípcia.

Ampliando este mito do herói, Jung afirma que a separação da "mãe" não é um processo destituído de dor e trabalho, já que por trás deste movimento existe o medo da morte. O neurótico que tem dificuldade de separação da mãe revela o medo de ser aniquilado. Porém esse conflito é extremamente importante, pois o homem precisa, dentro de um processo de desenvolvimento saudável, sair de sua inconsciência animal, amalgamado à figura da mãe, para iniciar seu processo de individuação. O que esta passagem mostra é que, para haver condições de surgir um novo e autêntico ser, morrer é necessário. O ritual de passagem traz a ideia de morte individual e definitiva, como afirma Jung (2013g).

A partir de outras culturas surgem mitologias díspares, mas com mesmo núcleo arquetípico. Jung apresenta um exemplo da cultura indígena por meio do mito de Hiawartha (Jung, 2013g). Este herói vive uma luta intensa e incessante contra a extinção. Hiawartha, assim como outros heróis (Hércules, Ulisses, Arthur e outros), luta contra a morte representada por grandes embates com dragões, feitiços, hydras e outros monstros e situações que podem aniquilá-lo. O herói é um símbolo da libertação individual, mas os oponentes são aspectos do próprio ser. Sendo assim, a busca não é externa, a luta é por 
paz, inteireza, pelo silêncio, por desenvolvimento. A morte aqui não é um inimigo externo.

Os exemplos citados ilustram como Jung analisa a morte em termos simbólicos, seja representando uma mudança importante, tanto em mitos quanto em sonhos. A morte é representada de diversas formas, como em travessias, transformações, ritos de passagem, revelações, iniciações, rompimentos, embates com monstros. De acordo com Jung, a morte é temida e desejada dentro de todo processo de desenvolvimento humano, pois ela faz parte do percurso tanto como metáfora das várias mudanças que o indivíduo vive, quanto como experiência em si.

Em Parisi (2009) temos:

A experiência subjetiva no momento de perda e dor presente na vivência do luto remete à mítica viagem à terra dos mortos ou mundo inferior como o Hades dos gregos, ou o Kur dos sumérios. A viagem pelo mundo dos mortos está representada na alquimia pela operação mortificatio ou putrefactio, associada ao estágio da nigredo e vinculada ao negrume, derrota, tortura, mutilação, morte e apodrecimento. Costuma ser experimentada como derrota e fracasso, mas pode dar início a um processo de transformação (EDINGER, 1990a). A experiência da descida e da nigredo costuma ser imposta pela vida, seja a partir do interior, seja a partir do exterior através de acontecimentos aos quais somos submetidos. A viagem ao mundo inferior representa uma morte simbólica, da qual, nos mitos, os heróis renascem, simbolizando um profundo processo de transformação, um ritual de passagem ou iniciação. A morte simbólica está presente em todos os rituais de iniciação; representa o momento central destas cerimônias. Segundo Eliade (1958) a iniciação é uma experiência existencial básica da condição humana, pois esta implica sempre em crises, provações, sofrimento, morte e renascimento, em que a morte prepara o novo, um nascimento espiritual a um novo modo de ser. A ida do herói ou heroína ao mundo dos mortos representa a entrada no inconsciente, e em geral corresponde a um estado depressivo. (Parisi, 2009, p. 56)

Ao passar pela ameaça de morte, o herói ou a heroína vivencia um estado de esvaziamento da libido representado pela entrada no mundo dos mortos. Esta etapa reflete o movimento de contato com os conteúdos inconscientes que precisam ser integrados para que seja possível a transformação, o renascimento no processo vida-morte-vida. Na Parte II desta pesquisa, sigo com a Psicologia Analítica, tratando mais especificamente da clínica e o manejo individual e em grupo, discutindo ambas em contexto de cuidados com o luto.

\subsubsection{Contribuições de Winnicott para compreensão do luto antecipatório}

No presente subitem, irei apresentar alguns aspectos da teoria produzida pelo pediatra e psicanalista Donald Woods Winnicott $(1896$ - 1971) que possam contribuir para a compreensão do processo de luto e seu manejo. Aqui serão apresentados conceitos 
muitas vezes irreconciliáveis com os da Psicologia Analítica, como "inconsciente" e "self" (Winnicott, 1964h). Sendo assim, o uso do constructo de Winnicott será realizado com o cuidado de mantê-lo em seu próprio paradigma, utilizando-o apenas para analisar o fenômeno em si (Fulgencio, 2020a).

Considerando que Winnicott inseriu a noção de "ser" na psicanálise (Fulgencio, 2015, 2017, 2020b; Roussillon, 2009), o modelo ontológico do ser humano foi modificado. A maneira de conceber qual é a especificidade do modo de ser do ser humano refere-se (ou está relacionada) à concepção existencialista que, ao diferenciar ser humano de outros entes, afirmar que aquele é o único que forja ou cria o mundo em que vive, cria a si mesmo e o outro. Nessa mesma perspectiva que caracteriza o Dasein, como um elemento que especifica a natureza humana, o homem é o único que reconhece a sua finitude e a do seu mundo, mais ou menos próximo, como algo que se dá no tempo, ou seja: no passado, no presente e no futuro. O ser humano é o único ente que tem este tipo de relação temporal com a finitude: o ser humano é o único que tem a apreensão de que a sua morte e a morte dos seus próximos é um destino.

Além disso, Winnicott também reposicionou a importância e o lugar dado à sexualidade no processo de desenvolvimento emocional do ser humano. Sem deixar de ser um fator determinante neste processo, Winnicott não reduziu os impulsos humanos à libido ou à sexualidade, ampliando, assim, de certa maneira, o que seriam os impulsos e os problemas essenciais do modo de ser humano (Fulgencio, 2020b). A divergência entre Jung e Freud sobre a natureza do que é a libido, em Freud restrita à vida sexual e em Jung mais ampla do que isto, teria aqui uma proximidade de perspectivas. Ainda que não esteja em questão analisar essa diferença entre Freud e Jung, ou esta proximidade entre Winnicott e Jung, certamente isso fornece características específicas ao processo de luto, seja lá em que perspectiva estejamos colocando este fenômeno.

É nesse quadro geral que pretendo retomar algumas das contribuições de Winnicott para articular os fenômenos que ele descreve com a maneira como Jung (e pósjunguianos) concebe o processo de luto e sua elaboração. Assim, neste capítulo tratarei das contribuições de Winnicott para o entendimento do luto que se instala anteriormente ao óbito. Em primeiro lugar, trarei alguns aspectos gerais da teoria winnicottiana do desenvolvimento emocional como o quadro construído pelo autor, o contexto e aspectos estruturais de seu paradigma. Em seguida, explicitarei qual é o seu modelo ontológico de homem, bem como sua teoria do desenvolvimento socioemocional. Na segunda parte do presente item, abordarei alguns fenômenos descritos por Winnicott que poderão ajudar 
na compreensão do fenômeno do luto antecipatório, tais como: os modos de ser/estar/relacionar-se durante o desenvolvimento e o holding nesse processo; a experiência da primeira morte e influências na constituição do ser e, por último, a construção da capacidade de ter "fé em..." e a noção da continuidade do ser versus quebra nessa continuidade (angústias impensáveis e impactos no processo de luto).

\subsubsection{Quadro geral da teoria psicanalítica do desenvolvimento emocional do ponto de vista de Winnicott ${ }^{15}$}

Winnicott descreveu um processo de desenvolvimento que não reduz o ser humano à tarefa de administração da sua vida instintual, nem à presença ou perda de “objetos" que atendam ou não às pressões instintuais. Diz Phillips (2007), nesse sentido:

Enquanto Freud se preocupava com as enredadas possibilidades de satisfação pessoal de cada indivíduo, para Winnicott essa satisfação seria apenas parte do panorama mais amplo das possibilidades para a autenticidade pessoal do indivíduo, o que ele chamará de "sentirse real". Na escrita de Winnicott, a cultura pode facilitar o crescimento, assim como o pode a mãe; para Freud, o homem é dividido e compelido, pelas contradições de seu desejo, na direção de um envolvimento frustrante com os outros. Em Winnicott, o homem só pode encontrar a si mesmo em sua relação com os outros, e na independência conseguida através do reconhecimento da dependência. Para Freud, em resumo, o homem era o animal ambivalente; para Winnicott, ele seria o animal dependente, para quem o desenvolvimento - a única "certeza" de sua existência - era a tentativa de se tornar "separado sem estar isolado". Anterior à sexualidade como inaceitável, havia o desamparo. Dependência era a primeira coisa, antes do bem e do mal. (Phillips, 2007, p. 29)

De acordo com Phillips (2007), Winnicott organiza sua teoria a partir do que compreende como sendo uma catástrofe essencial, que no caso é a ameaça da aniquilação do self central, caracterizado pela falha no ambiente de sustentação: "Cada teórico da psicanálise, poder-se-ia dizer, organiza sua teoria em volta do que poderia ser chamado de uma catástrofe essencial, para Freud era a castração; para Klein, o triunfo da pulsão de morte; e para Winnicott era a aniquilação do self central $^{6}$ pela intrusão, como falha no ambiente de sustentação" (Phillips, 2007, p. 209).

É este quadro geral que pretendo esboçar para, então, poder abordar alguns fenômenos que ele descreve e que poderão ser úteis para compreensão do processo de

\footnotetext{
15 Há diversos comentadores apresentando perspectivas de entendimento geral da obra de Winnicott (Abram, 2007, 2008; Dias, 2003; Fulgencio, 2020b; Phillips, 2007; Spelman, 2013a, 2013b). Estarei me apoiando no ponto de vista apresentado por Fulgencio (2020b), ainda que haja diferenças entre as maneiras como os diversos comentadores apresentam o pensamento de Winnicott. Não é meu objetivo nem necessidade comparar estas perspectivas de interpretação da obra de Winnicott; para mim, trata-se mais de usar aquilo que considero adequado ao desenvolvimento do meu tema e das propostas clínicas que podem daí derivar.
} 
elaboração do luto antecipatório. Retomarei, abaixo, uma série de concepções e posições teórico-descritivas para fornecer os aspectos gerais desse quadro.

Winnicott criou sua teoria a partir de sua experiência profissional, reconhecendo que havia problemas muito primitivos, como o adoecimento de bebês, que não eram redutíveis à compreensão do ser humano como constituído apenas pelo cenário edípico na administração da vida instintual:

... por ser eu um pediatra com talento para conseguir que as mães contassem sobre seus filhos e sobre a história precoce dos distúrbios de suas crianças, fiquei logo em posição de ficar impressionado tanto pelo insight que a psicanálise dava das vidas das crianças como por uma certa deficiência na teoria psicanalítica. . . . Então, inumeráveis histórias clínicas me mostravam que crianças que se tornaram doentes, seja neuróticos, psicóticos, psicossomáticos ou antissociais, revelavam dificuldades no seu desenvolvimento emocional na infância, mesmo como bebês. Crianças hipersensíveis paranoides podiam até ter começado a ficar assim nas primeiras semanas ou mesmo dias de vida. Algo estava errado em algum lugar. Quando vim a tratar crianças pela psicanálise pude confirmar a origem das neuroses no complexo de Édipo, mas mesmo assim sabia que as dificuldades começavam antes. (Winnicott, 1965va, p. 157).

Não só com bebês, mas também com pacientes psicóticos e/ou borderline, Winnicott deparou-se com sintomas do tipo "sentimentos de irrealidade", "futilidade", "sentimentos de aniquilação" etc. que, certamente, estavam associados à primeira infância. Nas palavras do autor, referindo-se a bebês afirmou:

No grau extremo de cisão, a criança não tem qualquer razão para viver. Nos níveis menos elevados existe um certo sentimento de futilidade relativo à vida falsa, e uma busca incessante daquela outra vida que seria sentida como real, mesmo que levasse à morte, por exemplo através da inanição. (Winnicott, 1990, p. 128)

Winnicott percebe que algo fundamental ocorre no encontro inicial mãe-bebê, algo que não havia ainda sido escrito e/ou compreendido pela psicanálise, especialmente no que se refere ao encontro e a sustentação ambiental do bebê, como um acontecimento que não se reduz ao fato da mãe atender (com alimento e prazer) ao bebê. Tratava-se, para ele, do que ele veio a caracterizar como sendo a continuidade de ser do bebê, quando tudo vai bem, ou, em outros termos, na saúde. Dado que, grosso modo, quando o self que sofre intrusão crônica do meio, a criança em sua continuidade do ser é quebrada e/ou interrompida.

Winnicott referiu-se a muitas questões do desenvolvimento, descrevendo suas dinâmicas, tais como os que estão destacados a seguir: a "questão do eu sou"; o conceito de "pessoa inteira"; a "atividade de criar e encontrar os objetos das próprias necessidades"; a "distinção entre ser e fazer"; os diversos "tipos de dependência"; a "constituição do verdadeiro e do falso self"; os "fenômenos transicionais" e a "atividade de brincar" etc. (Fulgencio, 2016; 2017). Não se trata, aqui, de analisar estes conceitos 
e/ou fenômenos, mas basta citá-los para ter a ideia do quadro geral no qual ele fez suas propostas teóricas e descritivas.

Assim, numa perspectiva geral, pode-se dizer que Winnicott pensa o desenvolvimento emocional em função dos movimentos que levam o ser humano do nãoser para o ser, do ser ao fazer, do estado de não integração inicial para uma diferenciação do eu e do mundo (Fulgencio, 2016, 2017, 2020b). Cabe ressaltar, no entanto, que todo desenvolvimento, para Winnicott, depende da sustentação ambiental adequada. Esse processo também pode ser descrito como sendo um conjunto de integrações, passando do estado de não integração inicial para a integração que poderá na saúde possibilitar a diferenciação do eu e do mundo de modos diversos (realidade subjetiva, transicional e objetivamente dada ou compartilhada).

Winnicott (1986k), no esforço de desenvolver uma psicanálise como ciência objetiva da natureza humana (1986k), e fortemente influenciado pelo humanismo e existencialismo (Fulgencio, 2020b) criou a possibilidade de uma psicanálise não objetificada, considerada por ele distante e presa a jargões que tornavam os fenômenos estrangeiros aos homens e às mulheres. Diz Winnicott (1957o): "um escritor da natureza humana precisa ser levado constantemente em direção a uma linguagem simples, longe do jargão do psicólogo, mesmo que tal jargão possa contribuir para revistas científicas" (p. 121).

Tais considerações abrem para a possibilidade de o homem ser olhado e tratado psicologicamente não como um objeto, o que transforma a estrutura da forma como o ser humano é visto, admitindo-se concepções de saúde, doença e de mudanças importantes na clínica psicanalítica. Na concepção de Winnicott (1971f), a tendência à saúde é um caminho natural dentro do processo do desenvolvimento humano, desde que o ambiente sustente e garanta a continuidade do ser. Apoiado nessa condição, o ser humano pode desenvolver sentimento de si e estabelecer uma personalidade individual, espontânea e criativa. "É somente pela continuidade da existência que o sentimento de si, do real e o sentimento de ser podem finalmente se estabelecer enquanto traço da personalidade individual" (Winnicott, 1971f, p. 24).

Winnicott considera que a origem dos distúrbios psicopatológicos em seus diferentes graus e formas não está ligado à genética, ou a neuropsicologia, mas às falhas nos cuidados ambientais no início da vida, somados aos conflitos provocados pela dificuldade na interação entre a vida instintual nas relações humanas. De acordo com Winnicott (1971g, 1988), um sujeito saudável não tem um funcionamento psíquico com 
características estereotipadas. Nesse sentido, uma das características da saúde é o viver criativo e não submisso. Um indivíduo que recebeu cuidados suficientemente bons pode tornar-se capaz de cuidar bem de si mesmo, ser concretamente independente sentindo-se livre para realizar as próprias escolhas, bem como sentir-se deprimido e arcar com as consequências de suas ações.

Winnicott (1971f) define a saúde da seguinte forma:

A vida de um indivíduo se caracteriza mais por medos, sentimentos conflitantes, dúvidas, frustrações do que por seus aspectos positivos. O essencial é que o homem ou a mulher se sintam vivendo sua própria vida, responsabilizando-se por suas ações ou inações, sentindo-se capazes de atribuírem a si o mérito de um sucesso ou a responsabilidade de um fracasso. Pode-se dizer, em suma, que o indivíduo saiu da dependência para entrar na independência ou autonomia. (Winnicott, 1971f, p. 30)

Esta concepção de saúde está de acordo com o seu modelo de homem/mulher, a sua ontologia que será abordada no decorrer do próximo item.

\subsubsection{O modelo ontológico do ser humano para Winnicott}

O modelo ontológico do que é o ser humano para Winnicott (1958j) segue a premissa de que o ser humano é um ser impulsionado por uma tendência inata à integração, sempre dependente do mundo, em maior ou menor grau. Para o autor o ser humano psicologicamente se desenvolve de um ser completamente dependente e imaturo, para um estado maduro relativamente independente. Como dito anteriormente, o autor preocupa-se com a questão da continuidade de ser, a experiência da continuidade de ser, e sua relação com o meio ambiente em todas as etapas de sua vida:

Gostaria de postular um estado de ser que é um fato no bebê normal, antes do nascimento e logo depois. Esse estado de ser pertence ao bebê, e não ao observador. A continuidade do ser significa saúde. Se tomarmos como analogia uma bolha, podemos dizer que quando a pressão externa está adaptada à pressão interna, a bolha pode seguir existindo. Se estivéssemos falando de um bebê humano, diríamos "sendo". Se por outro lado, a pressão no exterior da bolha for maior ou menor do que aquela em seu interior, a bolha passará a reagir à intrusão. Ela se modifica como reação a uma mudança no ambiente, e não a partir de um impulso próprio. Em termos do animal humano, isto significa uma interrupção no ser, e o lugar do ser é substituído pela reação à intrusão. Cessada a intrusão, a reação também desaparece e pode haver, então, um retorno ao ser. (Winnicott, 1990, p. 148)

De acordo com Winnicott (1994), seria lógico descrever o desenvolvimento do ser humano desde a concepção. Para o autor, o processo de amadurecimento na saúde tem início na concepção e termina com a morte natural, já que a experiência da morte, considerada a última tarefa na saúde, deverá ser integrada. Winnicott acaba bebendo de 
algumas percepções de Jung, e uma delas está relacionada à compreensão de que o desenvolvimento continua até o momento da morte:

Mais útil é a posição de Jung, que chamou "a nossa atenção para o fato de que os seres humanos, exceto na medida em que se acham apanhados na rigidez de suas próprias defesas, continuam a crescer em todos os sentidos, até o momento da morte" (1989a, p. 284; tr. p. 219). O valor da vida não está no progresso social ou material, no aperfeiçoamento e no "desenvolvimento", mas, como foi indicado anteriormente, na criação, em primeira pessoa, de mundos (ambientes) e de relacionamentos bons com os objetos neles encontrados ou encontráveis, bons no sentido de valerem a pena ("um objeto bom não é bom para o bebê a menos que seja criado por este")[sic] (Loparic, 2014, p. 4).

Segundo Loparic (2014), o amadurecimento sob o ponto de vista de Winnicott não é caracterizado pelo movimento de ascensão retilíneo, este processo ocorre, de acordo com o autor, em movimentos de sobe e desce, ampliando-se em círculos mais e mais amplos até que, por fim, ele alcança o grande círculo da vida e da morte. A morte é, sem sombra de dúvidas, incluída em sua teoria porque a vida é estruturalmente "um intervalo entre dois estados de não vida" (Winnicott, 1994, p. 154). Nesse sentido, para Winnicott, a vida humana agrega duas experiências de morte, sendo que a primeira, que ocorre ainda na primeira infância. Esse ponto será tratado com mais detalhes no decorrer da tese.

Para Winnicott (1990), a continuidade do ser está relacionada à saúde. Nos casos em que a psique necessita encontrar alternativas para fazer frente ao meio intrusivo, passa ao estado de reagir ao meio, e a ação de reagir interrompe o ser e pode aniquilá-lo (Winnicott, 1960c). Esta questão está relacionada a outro ponto da ontologia de Winnicott conhecida como a tendência inata à integração: "Pode-se considerar que a noção de continuidade de ser tem como correlato a consideração da existência de uma tendência inata à integração, de modo que se pode afirmar que Winnicott compreende a tendência inata à integração como sendo o que fornece o impulso em direção ao ser e ao continuar sendo" (Fulgencio, 2017, p. 265).

Para que a continuidade de ser possa ter lugar, é necessário que o ambiente possa sustentar o indivíduo sem invadi-lo. Winnicott afirma:

A ansiedade nestes estágios iniciais do relacionamento paterno-infantil se relaciona com a ameaça de aniquilamento, e é necessário explicitar o que significa este termo. Neste lugar que é caracterizado pela existência essencial de um ambiente sustentador, o "potencial herdado" está se tornando uma "continuidade do ser". A alternativa a ser é reagir, e reagir interrompe o ser e o aniquila. (Winnicott, 1960c, p. 47)

Estas balizas gerais podem ser encontradas na maneira como Winnicott descreve como é e como se desenvolve o processo de amadurecimento socioemocional, o que passo, agora, a tratar. 


\subsubsection{A teoria do desenvolvimento socioemocional do ponto de vista de Winnicott}

Winnicott tem como ponto de partida a consideração de que o ser humano é imaturo, tanto emocional como cognitivamente, no começo (da primeira infância): "no início há a não-integração, não há vínculo algum entre o corpo e psique, e não há lugar para uma realidade não-eu" (Winnicott, 1990, p. 153). Neste período, é necessário que o bebê esteja amalgamado a um outro ser que esteja responsável pela sustentação de suas necessidades

. . . isso que chamam de bebê não existe . . . se vocês mostrarem um bebê, mostrarão também, com certeza, alguém cuidando desse bebê, ou ao menos um carrinho no qual estão grudados os olhos e os ouvidos de alguém. O que vemos, então, é a 'dupla amamentante"'. (Winnicott, 1958d, p 165)

Para Winnicott, a qualidade da interação primária com o ambiente, como dito anteriormente, é um fator decisivo para o desenvolvimento do indivíduo, pois é a partir desta construção inicial que ele será capaz de existir num mundo complexo fazendo valer os seus direitos. Nesse sentido, o autor afirma que o humano desenvolve de um estado completamente dependente para um modo relativamente independente (Winnicott, 1989vk).

Dentro desta perspectiva, passo a apresentar resumidamente os aspectos gerais do desenvolvimento descrito por Winnicott e, em seguida, detalharei cada fase de acordo com os constructos do autor. Todos estes pontos fazem parte dos aspectos gerais do processo de desenvolvimento tratado por Winnicott na seguinte sequência:

Fase da Dependência Absoluta. Neste estado o lactente não tem meios de perceber o cuidado materno, que é em grande parte uma questão de profilaxia. Não pode assumir controle sobre o que é bem ou mal feito, mas apenas está em posição de se beneficiar ou de sofrer distúrbios;

Fase da Dependência Relativa. Aqui o lactente pode se dar conta da necessidade de detalhes do cuidado materno, e pode de modo crescente relacioná-los ao impulso pessoal, e mais tarde, num tratamento psicanalítico, pode reproduzi-los na transferência;

Fase Rumo à Independência. O lactente desenvolve meios para ir vivendo sem cuidado real. Isto é conseguido através do acúmulo de recordações do cuidado, da projeção de necessidades pessoais e da introjeção de detalhes do cuidado, com o desenvolvimento da confiança no meio. Deve-se acrescentar aqui o elemento de compreensão intelectual, com suas tremendas implicações (Winnicott, 1960c, pp. 45-46).

Importante registrar aqui, mesmo que apenas como citação, que Fulgencio (2020b) divide a fase rumo à independência em duas: fase da independência relativa infantil $^{16}$, que vai de 18 meses até 10 ou 11 anos de idade, e a fase da Independência

\footnotetext{
16 "A fase da independência relativa infantil (de 18 meses até 10 ou 11 anos de idade) pode ser dividida em: 1) fase da independência relativa infantil dual, com início da conquista da integração eu sou, que estabelece a distinção eu-não-eu, mundo interno e mundo externo; a lógica inicial de que haveria dois tipos de corpos
} 
Relativa Adulta ${ }^{17}$, que tem início aos 10 ou 11 anos indo até a última integração final: a morte.

Passo agora a detalhar um pouco mais as características do desenvolvimento, começando pela primeira etapa, ou seja, pela fase da dependência absoluta. Winnicott se ocupa em compreender o nascimento do eu, que ocorre ainda nesta fase, e investe em localizar quais os processos que ocorrem do momento zero até a chegada do eu. No início, mesmo sendo cuidado e atendido em suas necessidades, o bebê não percebe o meio, muito menos uma organização do ambiente (padronização ou planejamento de cuidados) que serão dedicados a ele.

Winnicott concebe peculiarmente sua teoria do ponto de vista do bebê e também do observador, diferenciando-os. Na primeira infância, o autor afirma que o bebê humano tem necessidades e o meio precisa responder-lhe suficientemente bem. Para o bebê ser considerado saudável, deve ter como característica a continuidade de ser, isto é, mesmo que haja uma intrusão do ambiente, há uma continuidade neste ser que suporta a disparidade entre sua necessidade e a resposta ambiental.

É importante ressaltar que, para Winnicott, a divisão do desenvolvimento em fases definidas é apenas válida para a investigação e conhecimento, e que "a criança está o tempo todo em todos os estágios, apesar de que um determinado estágio possa ser considerado dominante." (Winnicott 1990, p.52). De acordo com Fulgencio,

Podemos também considerar, de forma geral, que a teoria do desenvolvimento emocional, ou teoria dos modos de ser-no-mundo, é descrita por Winnicott não em termos das relações de objeto impulsionadas pela vida instintual, mas pela linha que leva os indivíduos do estado de não-integração inicial para os diversos tipos e graus de integração, da dependência absoluta inicial em relação ao ambiente para o estado dinâmico da independência relativa, do estado de não-ser para o de ser-no-tempo etc. Trata-se, pois, de apresentar a maneira como Winnicott entende quais são os fatos e conquistas que caracterizam o desenvolvimento dos modos de ser-no-mundo, bem como caracterizar as transformações que ele realizou na compreensão psicanalítica deste processo,

(eu e não-eu) desenvolve-se em uma série de integrações (da instintualidade, que passa a ser vivida como algo interno ao self; dos aspectos bons e maus do eu e dos objetos, que leva a viver os impulsos amorosos e destrutivos em associação; a experiência de destruir e reparar, ou seja, a vivência do ciclo benigno até a chegada à experiência de ser e sentir-se como uma pessoa inteira (whole person) que se relaciona com outros, também reconhecidos como pessoas inteiras (de 18 meses a 2 ou 3 anos de idade); b) a fase edípica, quando a pessoa inteira está colocada em um cenário edípico, e na qual prepondera a tarefa de administrar a vida instintual nas relações interpessoais, com todas as projeções, introjeções e identificações que ocorrem nelas, além das relações com o pai como um terceiro; c) a culminância, com o fim da primeira infância, a entrada e a vivência do período de latência (com diminuição temporária das pressões instintuais)" (Fulgencio, 2020b, p.131).

17 "Os acontecimentos descritos anteriormente, em conjunto, finalizam a fase da independência relativa infantil, dando início à fase da independência relativa adulta (de10 ou 11 anos até a morte final), que tem como subfases a adolescência, a conquista da vida adulta, a velhice e o último acontecimento, que conclui o tempo da existência, fechando o livro da história pessoal, a integração final: a morte" (Fulgencio, 2020b, p.138). 
explicitando alguns aspectos de seu lugar na história da psicanálise. Nessa perspectiva é possível, pois, caracterizar a proposta de Winnicott, usando uma denominação e expressão descritiva, como sendo uma teoria do desenvolvimento dos modos de ser-nomundo (Fulgencio, 2017, p. 132).

$\mathrm{Na}$ fase de dependência absoluta (até aproximadamente quatro meses de vida) o bebê não tem condições maturacionais para perceber objetivamente os cuidados da mãe, nem de julgar as ações do meio, somente beneficiar-se ou sofrer com a intrusão. É nesta etapa que o bebê vive a fase do objeto criado e encontrado, tendo uma ilusão de onipotência. O bebê quer algo em algum lugar e, para ele é a partir da sua necessidade que nasce o objeto do qual ele necessita. Aqui a onipotência refere-se à ilusão de que basta necessitar do objeto que, em seguida, este aparece. Tal movimento foi denominado de pacote de projeções: conjunto de necessidades que são satisfeitas, por exemplo, o bebê sente uma pressão (fome) e surge o peito da mãe (leite que sacia). Porém vale salientar que não se trata de um ato só, esta ilusão se constrói a partir de um conjunto de ações.

Como dito anteriormente, para Winnicott, o ser humano tem uma tendência inata à integração, o que é diferente das necessidades instintuais que são necessidades do ego. O lactente tem uma tendência a integrar-se e isso é possível, segundo o autor devido às experiências com o manejo materno e as "agudas experiências instintivas que tendem a aglutinar a personalidade a partir de dentro" (Winnicott, 1978, p.224). A tendência a integrar-se é ajudada por dois conjuntos de experiências: a técnica pela qual alguém mantém a criança aquecida, segura-a e lhe dá banho, balança-a e a chama pelo nome, e também as agudas experiências instintivas que tendem a aglutinar a personalidade a partir de dentro (Winnicott, 1945h).

$\mathrm{Na}$ fase da dependência absoluta, Winnicott afirma que existe uma relação importante entre ambiente e desenvolvimento psíquico, colocando em relevo a importância da sustentação ambiental. O bebê, como dito anteriormente, simplesmente não existe como entidade autônoma, ele só existe no amálgama mãe-bebê, e somente por meio dessa dependência é que ele pode amadurecer e viver por si mesmo. Sendo assim, em geral a mãe é quem atende suas necessidades básicas, fisiológicas e instintuais do bebê, sendo ela (ou adulto responsável) o ambiente de sustentação do bebê.

Inicialmente, no estágio da primeira mamada teórica, integração significa inserção no tempo e no espaço de todos os dias (1965b, p. 59; tr. p. 58). Apoiado no holding, nos braços da mãe, o bebê humano cria um senso pessoal do tempo (e do espaço) (1965b, p. 77; tr. p. 74), que lhe permite experienciar a execução de gestos ou atos completos, por exemplo, o de mamar. Nessa altura, há apenas o simples estado de ser e a "aurora da consciência da continuidade do ser e da existência no tempo" (1988, p. 135; tr. p. 157). Posteriormente, no estágio dos fenômenos transicionais, o indivíduo criará o espaço e o tempo potencial ou, como diz Winnicott ainda, o "contínuo espaço tempo" (1971a, p. 59) 
entre si mesmo e o ambiente - mãe, pais (casal), família, escola, sociedade, humanidade, história -, no qual vai poder brincar e viver criativamente. Chegará o tempo de experiências instintuais, da criação do mundo, da capacidade de viver com outros seres humanos, do senso de oportunidade ou do senso de responsabilidade. Nesse meio tempo, o indivíduo ter-se-á constituído como unidade pessoal em condições de manter, no espaço-tempo potencial, relacionamentos pessoais com ambientes sucessivos cada vez mais amplos, que vão desde o colo da mãe até o mundo social, a humanidade inteira e mesmo, no limite, a história da humanidade, e com objetos de diferentes tipos encontrados nesses ambientes (Loparic, 2014, p. 6).

Contudo, é importante afirmar que não é somente a mãe que realiza a sustentação ambiental. Os adultos afetivamente responsáveis também o fazem. Sendo assim, onde se lê "mãe" também está implícito "adultos responsáveis". São muitas as diversidades da vida e existe a possibilidade desse bebê receber cuidados fundamentais de um outro adulto ou adultos de referência que não sejam a mãe, por exemplo, o próprio pai, avós, tios, babá etc. Na fase da dependência absoluta, ocorre a adaptação feita de uma maneira específica pela mãe/adulto responsável às necessidades do bebê, sem que o bebê perceba o ambiente. À medida que se mantém constante, a mãe permite que o bebê se relacione com suas ansiedades ligadas aos impulsos fisiológicos, mas também àquelas que surgem na relação com tempo, ao espaço e aos afetos, passando a elaborar suas experiências a partir de si mesmo (Winnicott, 1990). Esta adaptação não precisa ser perfeita, mas deve facilitar a experiência de ser atendido de maneira razoável em termos de tempo e espaço, para que o bebê não tenha sentimento de desesperança e se torne desiludido com o ambiente.

Com os cuidados suficientemente bons, a criança passa a sedimentar integrações cognitivas e emocionais, a partir das quais começa a perceber um algo externo, já que aos poucos começa a ter certa noção de que existe uma dissonância entre suas necessidades e a ação que as saciam. "A partir da matriz de uma relação mãe-bebê suficientemente boa o ego é capaz de desenvolver-se" (Abram, 2000, p. 120). Dentro deste primeiro momento, a dinâmica entre ser uma "porção de pedacinhos" ou sentir-se um único ser, está tudo bem para um bebê normal (Abram, 2000, p. 224). A questão é que esse bebê em algum momento deve se tornar uno e podendo sentir algo. As experiências do bebê, na sua unidade psicossomática, vão trazendo coloridos diferentes à sua experiência, isto é, sentidos que colorem a existência.

Já na fase da dependência relativa (4 meses a 1,5 anos aproximadamente), o bebê ainda vive a relação do objeto criado e encontrado, mas passa aqui para uma mudança na relação com este objeto, o que provoca o que Winnicott chamou de desilusão de onipotência. O lactente começa a perceber os cuidados da mãe e passa a relacioná-lo com as necessidades internas (impulso pessoal). Se na primeira etapa o bebê encontra-se 
fundido à mãe sob o seu ponto de vista, na segunda ele já percebe uma realidade externa e consegue antecipar os acontecimentos e perceber padrões nas ações da mãe. Neste ponto do desenvolvimento, a criança passa a vivenciar uma fase de desilusão, momento em que desenvolve outra relação com o objeto. Aqui a criança cria objetos transicionais com o intuito de suprir a falta da mãe.

Os objetos são criados e encontrados; ao mesmo tempo, a realidade interna e externa se junta e se separa, dado que os objetos transicionais [como um ursinho, por exemplo] não são uma realidade somente externa ou interna; eles são, paradoxalmente, internos e externos, e constituem aquilo que Winnicott denominou uma terceira área da experiência. É por essa passagem, à qual se acrescenta uma série de outros processos, que a criança chegará a integrar-se num EU SOU, que é diferente daquilo que a criança passa a reconhecer como Não Eu, ou seja, é nesse caminho que surgirá a realidade externa como tal, ao mesmo tempo em que surge o EU como tal. (Fulgencio, 2016, p. 30)

Nesse sentido, a mãe suficientemente boa continua a suprir as necessidades do bebê, mas já é possível ter uma falha moderada no tempo de cuidado. Os objetos transicionais têm um lugar intermediário entre a realidade interna e a externa, e são controlados pela criança, principalmente no brincar. Este espaço transicional mantém-se por toda a vida e servirá para aliviar o adulto em momentos de tensão existente entre a vida interna e externa.

É com base no brincar, que se constrói a totalidade da existência do homem. Não somos mais introvertidos ou extrovertidos. Experimentamos a vida na área dos fenômenos transicionais, no excitante entrelaçamento da subjetividade e da observação objetiva, e numa área intermediária entre a realidade interna do indivíduo e a realidade compartilhada do mundo externo aos indivíduos. (Winnicott, 1971r, p. 93)

Para Winnicott, a ação de criar e encontrar o mundo por meio de objetos e fenômenos transicionais acaba propondo que o próprio ser humano é quem cria o mundo em que vive. Segundo Winnicott (1971r, p. 80) "É no brincar, e somente no brincar, que o indivíduo, criança ou adulto, pode ser criativo e utilizar sua personalidade integral: e é somente sendo criativo que o indivíduo descobre o eu (self)".

O brincar é um indicador de que a criança (e o adulto) utiliza a citada terceira área, o que sinaliza um desenvolvimento na saúde. Winnicott valoriza o brincar já que, para o autor, é uma maneira de vivenciar o self e comunicar-se. Mais interessado na ação do que no conteúdo, o autor entende o brincar como um indicador do desenvolvimento da criança e de seu sentimento de ser.

Um ponto importante que precisa ser tratado é que, nesta etapa do desenvolvimento, o bebê passa buscar paulatinamente interação com o ambiente, e precisa da permissão da mãe (ou adulto responsável) para tal interação. Caso seja impedido de buscar o ambiente em nome de uma superproteção (de cuidados excessivos), 
pode haver também traumas e desilusões no bebê, o que, por sua vez, irá interferir sensivelmente no desenvolvimento emocional e social do bebê. $\mathrm{O}$ brincar é uma forma de comunicação e conduz ao relacionamento com o ambiente, com o outro e com os grupos, uma ação universal e que acontece na saúde.

Nesta fase, é importante que a criança tenha a possibilidade de usar os objetos e experimentá-los (fenômeno transicional) sem críticas ou intervenções demasiadas e que interditam a exploração. É importante ressaltar então que nesta fase a criança desenvolve a capacidade de lidar com o ambiente, de brincar e, aos poucos, tolerar ausências, frustrações, a habilidade de lidar com perdas e conquistar a capacidade de ficar só (1958g, 1965r). De acordo com o autor, esta capacidade origina-se nas experiências integradas até então e apresentam-se como um paradoxo relacionado à experiência de ficar só, quando acompanhado.

$\mathrm{Na}$ fase de dependência relativa, os objetos e fenômenos transicionais representam, um modo de interagir com o ambiente no qual os objetos são criados e encontrados paradoxalmente interno e externamente. Segundo Winnicott (1953c, p. 30), "Não é o objeto que é transacional. Ele representa a transição do bebê de um estado em que este está fundido com a mãe para um estado em que está em relação com ela como algo externo".

Nesse processo, as integrações realizadas no cotidiano culminarão na percepção de um "eu sou", discernindo do que é o não eu. O ambiente ainda precisa ser propício e não pressionar a criança ao reconhecimento do que é externo e à compreensão de sua própria unidade, além do que ela está pronta para responder. Contudo, segundo Winnicott $(1965 \mathrm{vc})$ este estágio pode traumatizar o bebê, já que agora existe "uma pessoa para ser traumatizada" (Winnicott, 1965vc, p.64). Nos casos em que o tempo de espera para atendimento das suas necessidades, ou mesmo quando as necessidades do bebê não sejam adequadamente cuidadas, pode haver um impacto na confiabilidade que tem no ambiente.

Propiciar ao bebê que ele possa criar aquilo que encontra é um cuidado de extrema delicadeza que não está contido em nenhum fazer específico da mãe, mas no "como", no modo como ela lhe apresenta as pequenas amostras de mundo que ele está apto a experienciar no âmbito de sua onipotência. No que se refere à constituição da capacidade para as relações objetais, o bebê depende por inteiro do modo como se lhe apresenta cada fragmento do mundo. São esses "modos de ser" dos cuidados, ou seja, é a totalidade dos cuidados que perfazem o mundo criado pela mãe, que estão atualizando de um determinado jeito, ou impedindo, também de uma determinada maneira, a tendência de ser do bebê e sua integração gradual numa unidade. É preciso, em primeiro lugar, que o mundo lhe seja apresentado em pequenas doses, de forma compreensível, que faça sentido, ou seja, que não o surpreenda. Também é necessário evitar coincidências que o sobrecarregam - não se muda o bebê de quarto no momento em que ele está com 
catapora ou dor de ouvido - , para não abusar da sua limitada compreensão. Além disto, se ele está recolhido em isolamento ou quietude, a mãe entende que ele não está lá para ser encontrado; abordá-lo, nessa ocasião, impondo-lhe necessidades de fora, é interromper sua continuidade de ser naquele momento. Mesmo porque, quando a criatividade do bebê está ausente, as amostras de mundo que a mãe apresenta não têm sentido. Por outro lado, se o bebê fizer o gesto e a mãe estiver ausente, distraída ou concentrada em si mesma, o gesto ficará parado no vazio, à espera de algo que não vem. O resultado, em qualquer desses casos, não é frustração — uma vez que ainda não há desejo, que é um sentimento altamente sofisticado próprio de um eu unitário -, mas quebra na continuidade de ser (breakdown). Se este é o padrão de atitude ambiental, pode ocorrer aniquilação. (Dias, 2003, p. 172-173)

Diante do exposto por Dias (2003), é imprescindível que a mãe/ambiente continue atenta e cuidadosa com o bebê, mesmo nesta fase, já que, em casos mais graves de intrusão, o bebê perde a esperança e passa a não mais investir no ambiente, nem interagir com ele para buscar o que deseja ou necessita (Fulgencio, 2016). Nesta fase, as falhas podem gerar distúrbios afetivos, como a depressão e, também, comportamentos antissociais (Winnicott, 1965vc). Winnicott aponta que o ambiente deve sustentar de acordo com a necessidade de cada caso, bem como sobreviver às ações amorosas e destrutivas da criança. De acordo com o autor, a criança exige um ambiente indestrutível:

... a criança exige um ambiente que seja indestrutível em circunstâncias essenciais: certamente o tapete ficará sujo e as paredes devam receber um novo revestimento, ou casualmente uma janela quebre, mas de qualquer maneira o lar mantém-se unido, sendo que por trás de tudo isso está a confiança que a criança deposita na relação de seus pais . .. (Winnicott, 1968e, p. 94)

Outro ponto importante a ser discutido, mesmo que brevemente, é com relação ao modo como Winnicott trata da relação da amamentação e da agressividade enquanto o bebê mama. Os impulsos agressivos são importantes para a aderência ao peito. Esta agressividade não pode, segundo o autor, ser compreendida como uma ação que signifique algo. A mãe deve proteger-se aos impulsos agressivos, mas sem retaliações ou vinganças, este processo será importante, já que esta dinâmica faz parte do sentimento de amor que está nascendo no bebê. Dessa forma, o bebê passa a lidar com os impulsos de agressividade derivada da agressividade sobre objetos bons (Winnicott, 1963b ). Dessa forma a mãe deverá sobreviver aos ataques. O autor afirma:

Ela tem uma função a cumprir sempre que o bebê morder, arranhar, puxar os seus cabelos e chutar, e esta função é sobreviver. O bebê se encarregará do resto. Se ela sobreviver, o bebê encontrará um novo significado para a palavra amor, e uma nova coisa surgirá em sua vida: a fantasia. É como se o bebê agora pudesse dizer para sua mãe: 'Eu a amo por ter sobrevivido à minha tentativa de destruí-la. Em meus sonhos e em minha fantasia eu a destruo sempre que penso em você, pois a amo'. É isto que objetifica a mãe, coloco-a num mundo que não é parte do bebê, e a torna útil (Winnicott, 1969b , p.26). 
A agressividade é um impulso advindo da libido. A criança, na socialização, terá que lidar com seu self cruel. Contudo, uma intolerância crônica do ambiente em lidar com estes impulsos acarretará uma não-integração. "Se o bebê é obrigado a ocultar seu self cruel por causa de um ambiente incapaz de tolerar a agressão, isto acarretará uma dissociação, - isto é, uma não-integração, um desconhecimento e uma divisão" (Abram, 2000, p. 10).

No período rumo à independência (iniciando com 1,5 anos e seguindo pela primeira infância, período de latência, adolescência, maturidade, velhice e morte), Winnicott aponta que a criança aos poucos desenvolve modos de viver sem o cuidado externo, e isto só seria possível porque durante o período anterior acumulou recursos importantes. Outro ponto relevante nesta fase é que há o desenvolvimento da compreensão intelectual, o que auxiliará no desenvolvimento do indivíduo daqui para frente (Winnicott, 1960c). Em seguida, o indivíduo seguirá se desenvolvendo na fase de latência, adolescência, a idade madura e velhice-morte. De acordo com Fulgencio (2016), a psique do indivíduo realizará:

. . . diversas integrações que vão ocorrer ao longo de sua existência (chegando à diferenciação entre mundo externo e mundo interno, conquistando uma unidade do sujeito psicológico em termos de um EU SOU díspar de tudo que é Não Eu, estabelecendo-se e sentindo-se como uma pessoa inteira que se relaciona com os outros como pessoas inteiras). (Fulgencio 2016, p.28)

Nesta fase, o indivíduo já tem acumulados uma série de recordações do cuidado e passa a criar meios para viver sem os cuidados que necessitou nas primeiras fases da infância, desenvolvendo a capacidade de cuidar de si mesmo. De acordo com Fulgencio (2016), paulatinamente o indivíduo se relacionará mais e mais com o mundo externo, e o compreenderá segundo as recordações integradas em sua história como ele é. Dificuldades nesta fase geram problemas do tipo neurótico, isto é, justamente dificuldades nas relações interpessoais e na administração dos impulsos nestas relações.

Para Winnicott, é na fase rumo à independência que ocorre a distinção entre o eu e o mundo, levando o indivíduo do não-ser para o ser, mas também do ser ao fazer (Fulgencio, 2016; 2017). A integração ocorre de uma realidade não-self para uma possível troca com os outros na cultura. Tal movimento de integração ocorrerá até a morte, momento em que o último ponto da história pessoal será vivenciado (Fulgencio, 2016). Nesta fase o ser humano ingressará em círculos cada vez mais amplos como a família, sociedade (política, religião etc.), até a possibilidade de ser um cidadão do mundo. 
Segundo Winnicott (1997), a criança precisará, no percurso de seu desenvolvimento, sair do colo de sua mãe, mas não para o "espaço sideral", de forma descuidada e abrupta. Para o desenvolvimento seguir saudável, o ambiente (confiável, não intrusivo) continuará sendo imprescindível (e um facilitador) para que o ser humano alcance a capacidade de compartilhar experiências, e agir de modo espontâneo rumo à descoberta do mundo externo. Em todo o percurso de seu desenvolvimento o ser humano terá relação com o ambiente e com os outros de seu entorno. Winnicott destaca que é importante para o processo de amadurecimento este contato do indivíduo com a vida social, coletiva, e mais especificamente com a família: “. . . não seria possível ao indivíduo atingir a maturidade emocional fora do contexto familiar ..." (Winnicott, 1997, p. 129).

Posteriormente, no estágio dos fenômenos transicionais, o indivíduo criará o espaço e o tempo potencial ou, como diz Winnicott ainda, o "contínuo espaçotempo" (1971a, p. 59) entre si mesmo e o ambiente - mãe, pais (casal), família, escola, sociedade, humanidade, história -, no qual vai poder brincar e viver criativamente. Chegará o tempo de experiências instintuais, da criação do mundo, da capacidade de viver com outros seres humanos, do senso de oportunidade ou do senso de responsabilidade. Nesse meio tempo, o indivíduo ter-se-á constituído como unidade pessoal em condições de manter, no espaço-tempo potencial, relacionamentos pessoais com ambientes sucessivos cada vez mais amplos, que vão desde o colo da mãe até o mundo social, a humanidade inteira e mesmo, no limite, a história da humanidade, e com objetos de diferentes tipos encontrados nesses ambientes. (Loparic, 2014, p.6)

Na saúde, o processo de socialização acontece sem a perda de si mesmo. De acordo com Fulgencio (2016):

A maturidade do ser humano é uma palavra que implica não somente crescimento pessoal, mas também socialização. Digamos que na saúde, que é quase sinônimo de maturidade, o adulto é capaz de se identificar com a sociedade sem sacrifício demasiado da espontaneidade pessoal; ou, dito de outro modo, o adulto é capaz de satisfazer suas necessidades pessoais sem ser antissocial, e, na verdade, sem falhar em assumir alguma responsabilidade pela manutenção ou pela modificação da sociedade em que se encontra. Encontramos certas condições sociais, e isso é um legado que temos que aceitar, e, se necessário, alterar; e é isso que eventualmente passaremos adiante àqueles que se seguirem a nós. (Winnicott, 1971f, p. 30).

Para Winnicott, a cultura, assim como a mãe, pode facilitar o crescimento humano, já que este só pode encontrar-se a si mesmo na relação com os outros (Phillips, 2007). De acordo com Fulgencio (2016), Winnicott propõe uma teoria da cultura:

. . como uma atividade que visa expandir um determinado modo de relação com a realidade (modo de ação que cria-encontra a realidade, os fenômenos transicionais) no qual o indivíduo afirma e encontra a si mesmo no mesmo momento (ou na mesma ação, a de brincar) em que encontra o outro. $\mathrm{O}$ ser humano cria o mundo da cultura para poder ser ele mesmo, afirmando-se na sua própria essência (ou seja, criar e dar sentido ao a si mesmo e ao mundo em que vive) (Fulgencio, 2014, p. 110). 
Para Winnicott, o ser humano ingressa na vida cultural via ação do brincar, motor da vida em grupo “. . . brincar conduz aos relacionamentos grupais. ..” (Winnicott, 1968i, p.63). Ao estarmos expostos à cultura, ao ter acesso a obras e manifestações artísticas populares e eruditas, não importa sua origem, não estamos dentro nem fora, estamos agindo numa terceira área da experiência. Esta dinâmica é importante para amadurecimento da vida interna e social, sendo fundamental a necessidade de ser e continuar sendo em “. . . termos da existência de um si mesmo que só pode, na verdade, ser se puder fazê-lo sem ser constrangido de fora." (Fulgencio, 2016, p.111).

Por fim é importante apontar que, mesmo sendo denominada fase rumo à independência, não existe a ideia de que seja alcançada a total independência, pois o modo de ser-no-mundo é pleno de oscilações entre a autonomia e a dependência:

A maturidade individual implica um movimento em direção à independência, mas não existe essa coisa chamada 'independência'. Seria nocivo para a saúde o fato de um indivíduo ficar isolado a ponto de se sentir independente e invulnerável. Se essa pessoa está viva, sem dúvida há dependência! (Winnicott, 1971f, p. 3)

Encerro assim a primeira parte do presente subitem no qual desenvolvi uma noção geral do constructo teórico de Winnicott, tratando mais especificamente do modelo ontológico e da teoria do desenvolvimento emocional, que serão úteis para a construção da próxima parte relacionada às contribuições do autor para a compreensão das questões relacionadas ao processo de enlutamento.

\subsubsection{Contribuições de Winnicott para compreensão do enlutamento}

Aqui serão apresentados três itens relevantes para a apresentação do que estou considerando como sendo as contribuições de Winnicott para o trabalho com familiares enlutados: no primeiro momento, serão tratados os modos de ser/estar/relacionar-se nas diversas fases do desenvolvimento emocional; em seguida, será tratada a experiência da primeira morte; por último, a constituição da capacidade de ter "fé em..." e a noção da continuidade do ser versus quebra nessa continuidade (angústias impensáveis e impactos no processo de luto).

\subsubsection{Modos de ser/estar e relacionar-se nas diversas fases do desenvolvimento emocional}


A partir de sua experiência clínica, Winnicott criou uma classificação dos pacientes que chegavam ao seu consultório. Nesta classificação ele levou em consideração os níveis de integração pessoal, desenvolvendo, assim, uma espécie de "bússola" para que terapeutas pudessem nortear suas ações. Este quadro seria, portanto, composto pelos pacientes tipo 1, 2 e 3, a saber:

1) aqueles que "funcionam em termos de pessoa inteira, cujas dificuldades localizam-se no reino dos relacionamentos interpessoais";

2) aqueles que são recém-chegados a essa condição, cujas personalidades só agora começaram a integrar-se e a tornarem-se algo com o que é possível contar;

3) aqueles que estão num modo de ser-no-mundo "remota e imediatamente anteriores ao estabelecimento da personalidade como uma entidade, e anteriores à aquisição do status de unidade em termos de espaço-tempo". (Winnicott, 1955d, p. 375 apud Fulgencio, 2017, p. 153)

Passo agora a tratar desses modos de ser, estar e relacionar-se no mundo apresentando com mais detalhes a classificação de Winnicott: os pacientes tipo 1 seriam aqueles que sofrem de neurose; os de tipo 2, ficam de certa forma na fronteira entre neuróticos e psicóticos (por exemplo, deprimidos e borderlines); e os tipos 3, os de estrutura psicótica propriamente dita.

A neurose é considerada por Winnicott como sinônimo de saúde. Caracterizados pela rigidez das defesas e baixo comprometimento da estrutura psíquica, os neuróticos se relacionam como pessoas inteiras com outras pessoas inteiras, conseguindo, de modo geral, administrar os impulsos amorosos e destrutivos em suas relações interpessoais. Ser uma pessoa inteira e agir a partir de si mesmo leva o ser a um fazer (diverso) no mundo. Para que o fazer tenha um sentido genuíno, precisa ocorrer a partir da experiência de ser.

O que faz com que a vida valha a pena ser vivida é justamente a possibilidade de agir por si mesmo, com base em uma individualidade que não é constituída reativamente ou, noutros termos, em uma ação que pode ser caracterizada como criativa ou espontânea. Ser criativo aqui não diz respeito a produzir algo 'novo' que tem valor social (no campo das artes ou de qualquer outro ramo do conhecimento), mas a ser espontâneo, a ser a partir de si mesmo, ainda que isto não tenha valor social. É tal como a criança que diz: 'pai, mãe, olha o que eu fiz!', dando uma cambalhota ou mostrando um garrancho disforme num papel... o importante é o gesto espontâneo, que é sentido como criativo, que é sentido como expressão de si mesmo. (Fulgencio, 2016, p.70)

De acordo com Winnicott (1971g), o viver criativo é saudável, sendo, portanto, a submissão crônica uma base doentia. Em termos estruturais, o paciente tipo 1 teria um ambiente suficientemente bom na primeira infância e, com isso, obteve a oportunidade de integrar-se em uma unidade a ponto de ter condições de no futuro cuidar de si mesmo e do outro. "O paciente [neurótico] existe como uma pessoa, é uma pessoa total, que reconhece objetos como totais; acha-se bem alojado em seu próprio corpo e a capacidade de relacionamentos objetais está bem-estabelecida." (Winnicott, 1989vl, p.53). 
Já os pacientes tipos 2 estão na fronteira entre a neurose e a psicose. Winnicott trabalha aqui com depressões e borderline. Os deprimidos se encontram em algum lugar entre a neurose e a psicose, possuem problemas com a permanência de sua integração em diversos espectros e intensidades e, também, dificuldades com a permanência dos objetos.

Na depressão, a pessoa deprimida está administrando os conflitos que surgem no que poderia ser chamado de 'alma' através de um controle global. Isto desce automaticamente, como uma nuvem. A organização da realidade interna que fornece o sentimento de depressão acontece de modo inconsciente, isto é, separadamente de qualquer coisa que possa ser chamada de deliberada. Da mesma maneira, a nuvem se levanta quando as coisas estão prontas para que isso aconteça. Este controle global pode afetar o corpo e, em alguns tipos de depressão, toda a fisiologia do corpo encontra-se em maré baixa. Os tecidos se acham menos vivos e um pouco mais próximos de estarem mortos. (Winnicott, $1969 \mathrm{~g}$, p. 428)

É interessante apontar aqui, em ocasião da presente pesquisa, a percepção de Winnicott acerca dos deprimidos que se encontram mais próximos da neurose, e aqueles que se encontram mais próximos a psicose:

No caso da depressão mais próxima à neurose, estamos numa situação do tipo descrita por Freud quando escreveu Luto e Melancolia: nesse tipo de depressão o paciente vive um luto permanente, pela perda de um objeto amado, objeto que ele incorpora como parte de si e sobre a qual lança uma série de reprimendas ou desqualificações (a sombra do objeto perdido, recai sobre o ego do paciente), numa ação que nega a perda do objeto, tornando-o vivo dentro do indivíduo. No caso da depressão mais próxima à psicose, o paciente não perde propriamente um objeto, mas o mundo que o sustenta e que lhe dá contorno ou integração e é, por isso mesmo, que ele vive um tipo de depressão relacionada a problemas de ser, de integrar-se, tal como é o problema central no caso das psicoses. (Fulgencio, 2016, p.85)

Os borderlines, assim como os deprimidos, têm problemas na personalidade total, na qual o self verdadeiro e o self falso têm certa disfunção em sua forma de operar. Para Winnicott, o verdadeiro self é a parte da personalidade que age espontaneamente de acordo com a própria continuidade de ser a partir de si mesmo frente a um ambiente que na saúde se adapta às suas necessidades. Já o falso self é um mecanismo de defesa que é constituído para proteger o verdadeiro self das invasões ou falhas ambientais, expressando respostas reativas e adaptativas ao ambiente invasivo. De modo geral, na saúde, o verdadeiro self é mais ativo, e o falso self opera em certos momentos para proteger o primeiro frente às necessidades de adaptação ambiental. Esse processo é harmônico: na doença, o falso self ocupa o lugar do verdadeiro, estando dissociados entre si; nessa estrutura, o falso self atua para manter o indivíduo adaptando as demandas do ambiente e gera na pessoa sentimentos de futilidade e irrealidade, vivendo uma vida que não é sua.

Pela expressão borderline quero significar o tipo de caso em que o cerne do distúrbio do paciente é psicótico, mas ele possui suficiente organização psiconeurótica para ser capaz de apresentar uma psiconerurose ou um transtorno psicossomático quando a ansiedade psicótica central ameaça irromper de forma grosseira. (Winnicott, 1969i, p. 172) 
Para finalizar, tratarei dos pacientes tipo 3 da classificação de Winnicott. São aqueles que estão num modo de ser-no-mundo "remota e imediatamente anteriores ao estabelecimento da personalidade como uma entidade, e anteriores à aquisição do status de unidade em termos de espaço-tempo" (Winnicott, 1969i, p. 172). São pessoas que desenvolveram esquizofrenia, autismo, transtornos globais de desenvolvimento etc. Devido as falhas de sustentação ambiental, eles deverão receber um holding correspondente à maneira da sustentação materna.

Para Winnicott, estes indivíduos têm dificuldades com o ser/estar no mundo, não se sentem alojados no próprio corpo e, nos casos mais graves, sentem-se desintegrados. Os conflitos são relacionados a este processo de ser e existir no mundo e a vivência de angústias impensáveis. De acordo com Winnicott, este paciente teve falhas na fase da dependência absoluta, falha do ambiente que não se adaptou às demandas instintuais e relacionais do bebê. É certo dizer na saúde as integrações ocorrem gradativamente constituindo no sujeito a noção de tempo, espaço, experiência de si mesmo e desenvolvimento da capacidade de ter fé num mundo que provê e sustenta.

Winnicott, assim, apreende a origem de psicoses que podem ocorrer inclusive nos primeiros horas/dias após o nascimento da criança, quando falhas intrusivas são sentidas pelo bebê que ainda não está integrado. O autor dá especial destaque ao ambiente como gerador das psicoses, considerando sempre um duplo constituído ambiente-indivíduo (Abram, 1996).

Em meu trabalho "Psicose e Cuidado Infantil", que apresentei em 1952, surpreendi a mim mesmo dizendo que a esquizofrenia é uma doença de deficiência ambiental, isto é, uma enfermidade que depende mais que a psiconeurose de certas anormalidades ambientais. É verdade que há também fatores herdados poderosos em alguns casos de esquizofrenia, mas deve-se recordar que, do ângulo puramente psicológico, fatores herdados são ambientais, isto é, externos à vida e à experiência da psique individual. (Winnicott, 1989vl, p. 97)

As falhas da mãe-ambiente estão relacionadas às falhas no estado de preocupação primária. Winnicott considera que a mãe deixa o bebê "cair", e essa "queda", ambiente não suficientemente bom, é considerado o oposto de holding, não permitindo que o bebê tenha o sentimento de ser real (Abram, 2000). Com o objetivo de proteger o núcleo do self contra as ansiedades impensáveis ou angústias primitivas, o ego cria um falso self.

Essas ansiedades são 'impensáveis' porque esse tipo de ansiedade não pode ser concebido, provocando impacto e trauma (reação à intrusão). Para Winnicott, as angústias primitivas constituem a intrusão. A intrusão causa no bebê o sentimento de que o self foi aniquilado. É o oposto do ser; é o trauma de aniquilação, é o que violenta o núcleo do self (Abram, 2000, p.31). 
Intrusão para Winnicott seria aquilo que interrompe a continuidade do ser. A intrusão é originada no ambiente.

A natureza de uma intrusão deriva essencialmente do ambiente; entretanto, a invasão pode ser tanto traumática ... quanto reconstituinte. Se o bebê for adequadamente protegido no princípio - recebendo um suporte egóico suficientemente-bom do ambiente - então, aprenderá gradualmente a enfrentar a intrusão, o que resultará no restabelecimento de sua consciência de self. No entanto, se a intrusão for por demais prematura ou intensa, o resultado será traumático, sendo que o bebê não poderá fazer outra coisa que não reagir. São as reações à intrusão ocorridas em determinado período as responsáveis pelos danos causados à personalidade, o que resulta em fragmentação. (Abram, 2000, p.32)

Diante do que foi apresentado até agora, podemos observar que os estudos de Winnicott são importantes para auxiliar na compreensão do luto antecipatório de cada familiar atendido na intervenção domiciliar. Caberá ao psicólogo avaliar caso a caso refletindo sobre a melhor forma de atendê-los. Numa família podem coexistir pacientes tipo 1,2 e 3, vivendo, cada um, o luto de maneira ímpar. Como dito anteriormente, os pacientes neuróticos, como pessoas inteiras, irão se relacionar com a ameaça de uma perda de modo diferente de uma pessoa estruturalmente psicótica que, ao perder seu ente querido, pode sentir, perceber que perdeu o próprio mundo, sua sustentação na vida. $\mathrm{O}$ terapeuta que atenderá o grupo familiar deve assim ter em mente que precisará avaliar no curso do tratamento quem são seus pacientes e definir assim o modo de holding adequado para cada grupo. Contudo, cabe pontuar que o terapeuta deverá antes de tudo ter o cuidado em manter uma postura acolhedora, confiável, viva e constante durante o trabalho de intervenção no contexto de atendimento de familiares em luto antecipatório.

\subsubsection{A experiência da primeira morte}

Alguns dos constructos winnicottianos aqui tratados pareceu-me úteis para pensar e continuar ampliando a compreensão das experiências de luto antecipatório. Ao buscar a literatura de Winnicott, pude entrar em contato com os seguintes pontos: a experiência da primeira morte e sua influência sobre a construção da noção acerca da segunda morte; e a ideia de que a morte, quando é anunciada, pode agir como um agente intrusivo ou mesmo aniquilador, a depender, é claro, do desenvolvimento socioemocional de cada pessoa que vivencia o luto antecipatório.

De acordo com Winnicott (1994), grosso modo, o ser humano percebe a finitude por duas experiências. Uma é por meio do contato com a finitude do outro, seja vivenciando a morte do passarinho, ou mesmo com a constatação de que o brinquedo quebrou e não funcionará mais. Estas são experiências universais, comuns que serão 
vivenciadas, mais cedo ou mais tarde, por todos. No entanto, há uma primeira experiência, anterior a qualquer consciência, anterior a estruturação do ego que imprime ao ser a noção fundamental de morte.

Winnicott (1990) identificou que o ser humano tem uma única experiência com a morte antes de sua morte efetiva. Dessa forma, para falar da segunda morte, precisa-se falar da primeira, fenômeno que acontece no início da vida. Analisando o processo do desenvolvimento humano, de modo geral, Winnicott (1990) observa que a pessoa humana percorre um continuum que vai desde a barriga da mãe até o último instante de vida. Sendo assim, existe um princípio e um fim bem delimitados, passíveis de serem cronologicamente localizados. Mas em que momento este início se dá? Qual o estado primeiro para o qual todos os seres teriam que retornar se desejassem reiniciar sua história? E acrescenta:

Qual é o estado do indivíduo humano quando o ser emerge do interior do não-ser? Onde fica a base da natureza humana em termos do desenvolvimento individual? Qual o estado fundamental ao qual todo ser humano, não importa a sua idade ou experiências pessoais, teria que retornar se desejasse começar tudo de novo? (Winnicott, 1990, p. 153)

Nesse ponto a grande inquietação de Winnicott seria justamente em compreender como e quando ocorreria o início do ser. Winnicott denominou de "primeira morte" o estado anterior à experiência da passagem do não ser para o ser. De acordo com Dias (2003), o processo ocorre dentro dos estágios primitivos, relativos à fase da dependência absoluta, anteriores aos estágios iniciais, relacionados à fase da dependência relativa na seguinte sequência:

Dos estágios primitivos, de dependência absoluta, fazem parte: 1) a solidão essencial, a experiência do nascimento e o estágio da primeira mamada teórica. Dos estágios iniciais, de dependência relativa, participam: 2) o estágio de desilusão e de início dos processos mentais; 3) o estágio da transitorialidade; 4) o do uso do objeto; e 5) o estágio do EU SOU. (Dias, 2003, p.97)

Para Winnicott (1994), a passagem do não ser para o ser no feto/bebê é permeada por um paradoxo, pois, para que este fenômeno ocorra, é preciso que não haja nenhuma intrusão que interrompa ou ameace tal processo, bem como a vivência do que ele denominou "solidão essencial". O paradoxo reside no fato de que, para que o feto/bebê vivencie a solidão essencial e realize a passagem supracitada, deverá necessariamente estar imerso em condições ambientais adaptadas a ele, sem precisar se preocupar ou sofrer pressão intrusiva externa que o retire de seu processo.

Aqui, neste início, a continuidade do ser do novo indivíduo é destituída de qualquer conhecimento sobre a existência do ambiente e do amor nele contido, sendo este o nome que damos (nesse estágio) à adaptação ativa de uma espécie e dimensões, tais que a 
continuidade do ser não é perturbada por reações contra a intrusão. (Winnicott, 1990, p.154)

É importante frisar que o feto/bebê não tem condições de perceber este contexto, não sabe, nem tampouco elabora racionalmente. Ele apenas vive experiências psicossomáticas. Como dito anteriormente, a psique do bebê é um monte de pedacinhos, ainda há aqui a não-integração, não existindo, neste momento, um olhar a partir do qual olhar. Contudo, de acordo com Winnicott, fica para toda a vida do sujeito o registro da passagem do não ser para o ser.

De acordo com o autor, o indivíduo emerge da solidão, estado anterior a qualquer possibilidade de reconhecer a própria dependência e confiabilidade absoluta no meio. $\mathrm{O}$ feto/bebê precisa necessariamente estar em total dependência da mãe/ambiente e ter um ambiente que se adapte suficientemente bem às suas necessidades. Nesse sentido, o ambiente nos primeiros anos do bebê tem função imprescindível, seja na vivência da solidão essencial, seja na passagem do não ser para o ser e, também, na construção saudável ou patológica da psique.

Existem alguns aspectos relacionados à solidão essencial que não foram bem esclarecidos por Winnicott. Nesse ponto, trarei as contribuições de Fulgencio (2019, 2020b) indicando que, ao analisar com mais precisão a questão da solidão essencial, teremos dois sentidos diversos: o primeiro relacionado à solidão essencial metafísica e o segundo à solidão essencial experiencial. Como dito anteriormente, o ser humano chega ao mundo, ao ser advindo de um estado de não ser que pode, dentro do quadro da teoria winnicottiana, ser considerado sinônimo de solidão essencial. A passagem da solidão essencial metafísica ou ontológica para a solidão essencial experiencial se dá dentro de uma noção peculiar e paradoxal.

De acordo com Fulgencio, a solidão essencial metafísica ontológica está relacionada a situação de que aquele que não existe está sozinho. Aqui se encontra o primeiro sentido da expressão relacionada à solidão essencial, e que se refere a um paradoxo vivido na situação que estamos observando, "uma solidão sem sujeito". O autor esclarece que podemos supor que o indivíduo ainda não existe, e que chegará ao ser ainda na barriga da mãe.

Contudo, no útero talvez ocorra um outro tipo de solidão, uma solidão relacionada à experiência vivida (de ser e continuar sendo). E aqui temos o segundo sentido da expressão relacionada à solidão essencial: “como não há realidade não-self, do ponto de vista do bebê, ele está só" (Fulgencio, 2020b, p.215). Este processo acontece sem que o 
feto/bebê tenha a ideia de que existe algo externo, nem placenta, nem mãe, nada. A experiência de ser é ser sozinho, porque não existe nada mais além daquele indivíduo. Ou seja, se não existe nada além do ser, ele está sozinho e isso também é um estado de solidão. Dessa forma, Fulgencio afirma que o bebê tem a experiência de ser sem um sou, sem continuidade, e este ponto pode ser caracterizado como uma solidão essencial experiencial.

Quando o bebê nasce, do ponto de vista externo, o observador pode ver a mãe e o bebê separados, mas, do pondo de vista do bebê, ele ainda permanece na mesma situação em que não há ainda uma realidade não-self (não eu). O bebê não tem maturidade para apreender uma realidade não-self e como diferenciada dele. Por isso, a expressão inicial do bebê, que é a experiência de ser e continuar sendo, que é essa experiência em que o ser humano não tem maturidade para ter a noção de qualquer realidade não-self poderá ser chamada também de uma experiência de solidão essencial, mas experiencial, diferente da solidão metafisica ou ontológica, a que me referi como solidão ontológica. Dessa forma, o segundo sentido da expressão "como não há realidade não-self, do ponto de vista do bebê, ele está só". Neste processo, ocorre então a passagem do estado de não vida (primeira morte) para o estado de estar vivo experiencial.

O feto/bebê não tem a capacidade de se preocupar com a morte, mas há, de acordo com Winnicott, a capacidade de lidar com a solidão. O bebê não tem medo da morte (Winnicott, 1990), o único medo que o bebê pode ter é o medo de deixar de ser, ele pode sentir angústia, medo de aniquilação, por intrusão do ambiente.

O bebê (ou o feto) não tem capacidade alguma de se preocupar com a morte. No entanto, deve existir em qualquer bebê a capacidade de se preocupar com a solidão da prédependência, já que esta foi de fato experimentada. Essa ideia não está sujeita, a meu ver, a alterações por possíveis incertezas quanto a data em que o bebê humano começa a existir. (Winnicott, 1990, p.155)

Dessa forma, a falha ambiental nos primeiros estágios da vida acionaria a ordem do insuportável na psique remetendo a uma experiência de agonia: “A alternativa a ser é reagir, e reagir interrompe o ser e o aniquila. Ser e aniquilamento são duas alternativas" (Winnicott, 1960c, p. 47). Este sentimento dilacerante está relacionado à ideia de deixar de ser, que foi vivenciado em algum momento da vida.

A primeira morte refere-se então a esta peculiar passagem. Contudo, a experiência da solidão essencial nunca mais poderá ser reproduzida, não há volta, é irretomável, apesar deste indivíduo continuar carregando a experiência vivenciada. O reconhecimento desta solidão enquanto experiência humana é certamente significativa para o sujeito. 
Winnicott afirma que durante toda a vida o indivíduo continua a se haver com ela, mas as condições fundamentais para o resgate desta solidão se mantêm inconsciente (Winnicott, 1990).

A solidão essencial do início será, portanto, ultrapassada, transposta, em algum sentido, uma vez que "não haverá jamais uma reprodução exata dessa solidão fundamental e inerente" (1988, p. 154). No entanto, ao mesmo tempo em que o estado de solidão inerente se altera, algo dele permanece e continua a haver uma solidão fundamental. Trata-se, portanto, de uma cisão, uma cisão básica, que está na raiz mesma da existência humana e que permanece "incurável": enquanto algo se mantém como um fundo intocável, eternamente solitário, uma outra parte do indivíduo é lançada na luz do mundo, para que possa nele habitar, para que a vida, que inclui viver na proximidade das coisas e com-ooutro, possa se instaurar e acontecer.

O indivíduo só "sabe" de sua solidão essencial quando, pela experiência do "primeiro despertar", a vida se imiscui na extrema quietude do início: "A experiência do primeiro despertar dá ao indivíduo a ideia de que existe um estado de não-estar-vivo cheio de paz, que poderia ser pacificamente alcançado por meio de uma regressão extrema" (1988, p. 154). E embora o bebê, ou o feto, não tenha nenhuma capacidade para se preocupar com a morte, ' deve existir em qualquer bebê a capacidade de sentir-se concernido pela solidão da pré-dependência, já que esta foi de fato experimentada" (ibid., 155). (Dias, 2003, p. 298)

Como dito anteriormente, a experiência com a primeira morte advinda da solidão essencial (estado de não-estar vivo) marca no indivíduo um ponto zero cheio de paz. Segundo Fulgencio (comunicação pessoal, 2 de junho de 2016), na primeira experiência de morte não há conflito, não há invasão, é puro. Para Winnicott, o ser humano, quando está frente a frente com a experiência incognoscível da segunda morte, deseja retomar este estado, já que será este o seu apoio frente às experiências de finitude ao longo da vida, trazendo as desejadas sensações de quietude e simplicidade. Dessa forma, a primeira experiência de morte não marca a ideia de finitude, mas sim de início.

Na morte, que é o grande retorno a solidão essencial se fechará sobre si mesma, completando o ciclo da vida. Enquanto o indivíduo estiver vivo, ela permanecerá com o fundo, como a reserva inconfigurável que entrega o homem à tarefa de existir como história inédita e pessoal, sem apoio em nenhuma determinação, sustentado tão-somente na ilusão de poder criar. Permanecerá também como matriz de todas as possibilidades de retorno, de recuo do indivíduo que, quando é saudável, sente necessidade de descansar da tarefa de existir e de ter de, permanentemente, separar a fantasia da realidade, o subjetivo do objetivamente percebido. A solidão essencial é a única verdadeira e desconhecidamente almejada quietude, a que mais se aproxima da condição de pura simplicidade que custa nada menos que tudo. (Dias, 2003, p.299)

Para Winnicott, o marcante ponto zero cheio de paz, como dito anteriormente, é desejado durante toda a vida. No indivíduo saudável existe o desejo de estar em paz relacionado ao momento de não-estar-vivo, e este desejo é ocultado na capacidade de estar só do indivíduo saudável, e de se fazer cuidado pela parte do self que tem exatamente esta função. Diversas vezes o indivíduo durante a vida sente desejo de alcançar este estar 
sozinho, contudo, o alcance é obstruído por inúmeras questões, como as ansiedades, por exemplo. Tal experiência é tão marcante que, mesmo na saúde, o indivíduo poderá sentir desejo de retorno ao citado estado-de-não-estar-vivo cheio de paz. De maneira geral, nenhum sujeito, mesmo na saúde, está imune à possibilidade de perder aquilo que o liga à vida e que dá sentido a ela. Qualquer humano pode ser confrontado à terrível morte interna, perdendo a vida criativa e o sentimento de que esta é real e significativa. Esta condição pode acionar o desejo de findar a própria existência, como, por exemplo quando se deseja o suicídio. Aqui o desejo do fim está relacionado, de acordo com Winnicott, à busca do fim do sofrimento, e ao desejo de reiniciar tudo (Dias, 2003). Winnicott (1990) afirma:

O estado anterior ao da solidão é um estado de não-estar-vivo, sendo que o desejo de estar morto é em geral um disfarce para o desejo de ainda-não-estar-vivo. A experiência do primeiro despertar dá ao indivíduo a ideia de que existe um estado de não-estar-vivo cheio de paz que poderia ser pacificamente alcançado através de uma regressão extrema. Muito do que geralmente é dito e sentido a respeito da morte, na verdade se refere a este estado anterior ao estar-vivo, no qual o estar sozinho é um fato e a dependência ainda se encontra muito longe de ser descoberta. A vida de uma pessoa consiste num intervalo entre dois estados de não-estar-vivo. O primeiro dos dois, a partir do qual emerge o estar-vivo, dá colorido as ideias que as pessoas costumam ter sobre a segunda [morte] (Winnicott, 1990, p. 154).

Winnicott aponta que a percepção, sentimento, compreensão de que os homens e mulheres têm com a questão da morte tem íntima relação com a vivência desta primeira morte. Dessa forma, a presença da ameaça da morte coloca o indivíduo em contato com a solidão histórica, afetiva, mas também com a solidão estrutural, que relembra o momento zero. Como dito anteriormente, esse momento zero tem a ver com recomeçar, reiniciar, livrar-se da dor e das dificuldades. O luto representa em essência uma resposta a um acontecimento potencialmente desestruturante que, apesar de não ocorrer de modo cotidiano, será vivenciado, mais cedo ou mais tarde, por praticamente todos os seres humanos pela morte de uma pessoa querida (Parkes, 1998). Visto isso, podemos pensar que, no contexto na qual uma morte é anunciada devido ao diagnóstico de doença grave que acometeu um ente querido, a experiência da primeira morte é acionada no processo de luto de cada familiar e entorno.

Sendo assim, pode-se pensar que o contato com a morte é um contato de ambiguidade, mas Fulgencio (comunicação pessoal, 2 de junho de 2016) alerta que a morte carrega algo mais do que uma ambiguidade, ela é um grande paradoxo. Sua presença forja algo que não pode ser desfeito. Com ela, a história é interrompida. Com a morte, se perde ou se perderá uma pessoa afetivamente importante. Nesta experiência, há 
o contato com uma solidão histórica, afetiva, mas também o contato com a solidão estrutural que relembra o momento zero, que tem a ver com recomeçar, reiniciar, livrarse da dor e das dificuldades, estar em paz.

Cada indivíduo que esteja neste contexto tem um modo de lidar com esta situação, que pode estar relacionado com a forma subjetiva que experienciou com a própria passagem do não ser para o ser. Outro ponto que influencia é relacionado ao modo de ser e estar no mundo relacionado ao processo de desenvolvimento socioemocional. Diante dessas duas condições estruturais, o luto antecipatório pode ser uma experiência cheia de ambivalências e dor psicológica, mas também pode ser sentida como uma ameaça de intrusão ou aniquilação do ser.

\subsubsection{A construção da capacidade de ter "fé em..." e a noção da continuidade do ser versus quebra nessa continuidade: as angústias impensáveis e impactos no processo de luto}

Para tratar da questão central deste subitem, precisarei retomar os primeiros meses do desenvolvimento humano, mais precisamente a fase da dependência absoluta e a fase da dependência relativa. Essas fases são imprescindíveis, como bem tratado anteriormente, para o desenvolvimento saudável ou não do ego que está nascendo. $\mathrm{Na}$ saúde, o indivíduo será capaz de desenvolver uma relação de fé e esperança frente ao mundo e no desenvolvimento patológico não será, devido a fragmentações em diversos níveis e a presença de angústias impensáveis.

Winnicott denominou preocupação materna primária todas as particularidades que envolvem o cuidado da mãe, e é justamente esta função que fornece ao bebê o devido suporte egóico (Abram, 2000). O bebê só se desenvolverá em contexto confiável decorrente do fato de ser efetivamente segurado e devidamente manipulado (Winnicott, 1968d ). Ser bem segurado ou ser desapontado gera respectivamente a construção saudável ou não da psique. A mãe (ou adulto responsável) que não realiza satisfatoriamente tal tarefa pode promover falhas ambientais, gerando na criança a sensação intrusiva e patológica de cair eternamente, ou seja, a vivência de uma angústia importante.

... uma ameaça de "ansiedade impensável", a ansiedade primitiva ou arcaica que bebês bem-cuidados não experienciam na realidade, antes de se acharem aparelhados para lidar com o fracasso ambiental através do autocuidado (maternagem introjetada). As ansiedades impensáveis desse tipo incluem: queda eterna; desintegração; despersonalização; desorientação. (Winnicott, 1994, p.108) 
No período em que o bebê está vivendo em dependência absoluta, que vai do nascimento até mais ou menos quatro ou cinco meses de vida, ele necessita que suas demandas sejam atendidas, não adiadas, não antecipadas demais, nem atendidas com falta ou excesso. O bebê que vive em um holding falho que não se adapta, que tem falhas na comunicação e que não está atento às suas necessidades gera nele um tipo de angústia, sofrimento extremo e que terão consequências no devir frente à quebra na continuidade do ser e continuar sendo. A angústia ou agonia impensável foi assim caracterizada por Winnicott (1968c) como derivada de fracassos na confiabilidade ambiental já nos estágios iniciais, por produzirem no bebê "fraturas" da continuidade pessoal devido às reações ao imprevisível. Essas são traumáticas porque conduzem consigo uma ansiedade impensável, algo como um sofrimento intenso.

Apesar que ainda não existir uma integração, uma unidade, o bebê tem sensações importantes. Winnicott não está falando das falhas relativas que são muito comuns na rotina de um bebê recém-nascido, mas de falhas fundamentais, de uma comunicação mãebebê profundamente comprometida, que pode gerar ansiedade, a sensação de espedaçamento, de cair eternamente, isolamento (sem comunicação), desconexão entre o corpo (soma) e a psique, um total colapso do estabelecimento do self unitário (Winnicott, 1968d). O bebê, frente ao ambiente cronicamente imprevisível e intrusivo que o desampara, terá que desenvolver uma atenção aguda, uma reação para precaver-se. É importante dizer que, na saúde, os adultos responsáveis pelo bebê irão se adaptar aos poucos às necessidades do bebê, que, por sua vez, irá gradualmente precisar mais do ambiente. O que quero dizer com este fato é que há um processo de adaptação, no qual a mãe vai conhecendo o seu bebê paulatinamente e segue, a partir do vínculo da dupla amamentante, lendo suas demandas desde o início da vida.

A fim de preservar um modo de vida pessoal já no início, o indivíduo precisa que as intrusões provocadoras de reações sejam mínimas. Todos os indivíduos buscam, na verdade, um novo nascimento, no qual a sua linha de vida não seja perturbada por uma quantidade de reações maior que a que pode ser experimentada sem que ocorra perda do sentimento de continuidade da existência pessoal. A saúde mental do indivíduo é fundada pela mãe que, por devotar-se ao seu bebê, pode adaptar-se ativamente a ele. Isto pressupõe um estado básico de relaxamento na mãe, e também uma compreensão do modo de vida individual do bebê, e isto também deriva de sua capacidade de identificar-se com ele. Esse relacionamento entre a mãe e o bebê inicia-se antes de o bebê nascer, e em alguns casos continua durante o nascimento e mesmo depois. (Winnicott, 1958f , p. 271)

O bebê apresenta um conjunto de demandas que deverão ser satisfeitas, como, por exemplo, a sua fome. O seio surge e a pressão que sentira é aliviada. Após sanada a 
necessidade de saciar a fome, o objeto desaparece. O bebê vai aprendendo com o tempo que, a partir do momento em que demandar algo, esse algo aparecerá.

Um bebê que dispõe de um holding satisfatório neste início seguirá seu caminho de amadurecimento sem marcas comprometedoras em sua saúde psíquica e (o que é mais importante) terá integrado e estabelecido no seu viver a segurança primeira que lhe dá amparo e confiança para prosseguir confiando que a vida vale a pena ser vivida porque encontrou um mundo que lhe foi favorável, sendo digno de confiança. (Júnior, 2009, p. 94)

É imprescindível que o bebê não sofra intrusões em seu processo. $\mathrm{O}$ bebê vive a ilusão de onipotência, fase em que experiencia o objeto criado e encontrado. A constância no movimento de integração no amálgama mãe-bebê caracterizado pelo movimento "necessidade do bebê" e "solução dada pelo meio" é fator primordial para a construção da capacidade de ter "fé em" e o sentimento de esperança. De acordo com Júnior (2009):

A compreensão de que o bebê vive a ilusão de onipotência e é encorajado para tal pela provisão materna permite estabelecer a grande base do que posteriormente, no decorrer do amadurecimento, se pode chamar de confiança, crença, fé. Porém, anterior a estas atitudes já estabelecidas como um comportamento, uma atitude ou um sentimento e como se lhe dessem substrato, surgiu a capacidade para tal identificada por Winnicott, neste contexto da ilusão, de onipotência. Houve uma primeira vez e houve alguém que confirmou que alguma coisa existia; e mais: que ele (o bebê) havia criado algo e este algo adquiriu certa consistência, pois houve quem confirmasse sua existência, impedindo que ele se achasse louco e a realidade inconsistente. Esta ilusão compartilhada marca, de certo modo, o surgimento de uma capacidade para acreditar. (Júnior, 2009, p. 100)

Winnicott (1990) afirma que, ao facilitar a experiência da ilusão de onipotência, o ambiente comunica ao bebê que "o mundo está sob o seu controle" (p. 90), que sua ação criativa é bem vinda no mundo e que ele pode criar um mundo que tenha significado para si.

Não pressionado por intrusões, mas facilitado de modo adequado e em momentos certos, o indivíduo cria um modo pessoal de viver no mundo, passa a se comportar e a operar espontaneamente, isto é, a partir do seu verdadeiro si mesmo, o que faz com que possa sentir que a vida vale a pena ser vivida. Dessas aquisições maturacionais, Winnicott extrai o que chama de "princípio fundamental da existência humana": "tudo aquilo que provém do verdadeiro si mesmo é sentido como real (e posteriormente como bom), seja qual for a sua natureza, não importa o quão agressivo; e tudo aquilo que acontece no indivíduo como uma reação à intrusão ambiental é sentido como irreal, inútil (e posteriormente como ruim), independentemente de quão gratificante seja do ponto de vista sensorial. (1958a, p. 292; tr. p. 389)". (Loparic, 2014, p.7)

Diante do que foi exposto, temos que Winnicott postulou a compreensão da origem da "capacidade de ter fé em..." na saúde, bem como a "vivência das angústias impensáveis" na patologia. Acontece que, durante a vida, seja em qualquer fase do desenvolvimento, o indivíduo pode vivenciar o contato com o luto e, em certas ocasiões, com o luto antecipatório. Esta situação é carregada de tensão e sentimentos ambivalentes, como ansiedades e medos. Em muitas situações é preciso que essa elaboração seja 
acompanhada por um profissional, como no exemplo que será trazido a seguir. É importante lembrar que o luto é um fenômeno multifacetado, carregado de ambivalências e que pode gerar nos enlutados impactos psicológicos, físicos, cognitivos, sociais, econômicos etc.

O que é necessário frisar aqui é que o indivíduo que foi suficientemente bem cuidado nas primeiras fases do desenvolvimento poderá ter uma relação de confiança com a vida e de ter esperança quando estiver numa situação de intrusão, como o estado de luto antecipatório. Não estou dizendo que o indivíduo que teve um holding suficientemente bom no início da vida não sofrerá com a ameaça da perda de um ente querido, mas sim que sua integração permitirá a ele que viva este momento de dificuldades e adaptações como pessoa inteira e que, frente a uma morte, o próprio mundo não será destruído, como acontece com os indivíduos que tiveram falhas no desenvolvimento. Nesse sentido, o indivíduo enlutado que teve um desenvolvimento saudável, no qual pode desenvolver sentidos de esperança a partir de uma experiência suficientemente boa na primeira fase da vida, poderá lidar melhor com a intrusão que o meio está lhe impondo e, assim, ter maior habilidade em se organizar, sendo capaz de recomeçar e, também, elaborar positivamente o vínculo com a pessoa perdida (ou que irá perder).

Já os indivíduos que possuem desenvolvimento patológico podem ter angústias impensáveis com maciço sofrimento e desalento existencial frente a perda (ou ameaça de perda) de uma pessoa importante. O medo da morte, como dito anteriormente, está relacionado ao medo da experiência de aniquilação da existência do ser que remete a vivência da iminência de não ser mais. Essa agonia remonta a algum (ou a vários) fato que vivenciamos durante a vida que marcam a ameaça de "deixar de ser", experiência de aniquilação do ser que já foi vivida em algum momento da vida. A ameaça da morte em um processo de luto antecipatório recupera em algum nível certos tipos de experiência que não conseguimos integrar e que ameaçam ou rompem com nosso sentimento de ser. É uma agonia impensável porque não há um sujeito ali para pensar, o medo da morte é simplesmente um afeto que toma o sujeito que vai deixar de existir, ou que vai ver o outro afetivamente próximo deixar de existir (Velano \& Azambuja, 2020). A fragilidade pode ser tangível à situação de que, com a perda do ente querido, o próprio mundo será perdido, destruído. O importante é que, em caso de necessidade, o processo de elaboração da perda seja acompanhado de um profissional que consiga realizar o holding adequado a cada tipo de paciente, auxiliando tanto neuróticos quanto psicóticos no processo de enlutamento (antecipatório ou pós-morte). 
Para finalizar o presente subitem, trarei um caso de atendido sob as bases da clínica de um ponto de vista winnicottiano relacionado ao processo de luto. Batistelli (2010) apresenta em seu artigo um estudo de caso na qual atende uma criança de 9 anos de idade que perdera seu pai subitamente quando estava com 3 anos. No caso avaliado como um exemplo de de-privação devido à perda do pai, o menino apresentava um comportamento antissocial na escola e em casa. O menino precisou de "um continente adequado para dar conta de tanta angústia, o que acarretava extravasamento e desespero" (p.157). A criança, durante o processo, checava a capacidade da psicóloga de estar viva, de ser capaz de acompanhá-lo sem se precipitar, sem ser destruída. O setting foi imprescindível para o desenvolvimento das sessões:

Penso, e essa era a linha mestra que me guiava nesses momentos, que o mais importante para o Lucas era experienciar se eu e o setting como um todo éramos capazes de sobreviver a cada encontro. Se apesar do barulho e da confusão em que muitas vezes ele se apresentava eu poderia me manter viva e inteira (Batistelli, 2010, p.157).

Num certo dia, Lucas levou um facão para a sessão. Anteriormente a esse dia, quando Batistelli se referia ao pai, Lucas rebatia com a frase: "Deixa ele em paz, coitado". Contudo, nessa sessão ele pode adentrar no momento quando estava realmente seguro no lugar da angústia da perda.

De que era com esse pai morto que, no final das contas, ele acabava se identificando como se tivesse que ter o mesmo destino. A angústia de não poder viver a continuidade que sobrevive à destruição. Eu apontava essas coisas para o Lucas e ele, de alguma forma, para mim. Ele sempre repetia, quando eu me referia ao seu pai a seguinte frase: "deixa ele em paz, coitado". Nesse dia ele me diz: "o meu pai foi um burro e fraco, pois se ele tivesse sido forte ele não teria morrido". (Batistelli, 2010, pp. 159-160)

A partir daí, a criança pode iniciar por meio de uma série de vivências a elaboração de sua dor, ressignificar o pai interno e sua agressividade. Aos poucos, o facão, enquanto símbolo foi esvaziado de sentido e não foi mais necessário nas sessões, ao passo que inúmeros objetos do pai foram trazidos na mochila (raquete de tênis, título de eleitor, caneta, talão de cheque etc.). A partir destes objetos, um pai vivo pode ser conhecido, um pai que teve uma história, que votou, jogou tênis, envelheceu, gerou Lucas e, também, morreu. A ressignificação do pai interno pode reorientar sua forma de estar no mundo dos homens, dos vivos.

Considerando esses dois aspectos podemos dimensionar o trabalho que Lucas tinha pela frente. Um trabalho que ele não tinha ainda condições internas de efetuar, e só poderia fazê-lo na companhia de alguém que a isso se dispusesse. Penso que de uma forma muito criativa, e bonita até ele pode usar o nosso espaço para construir esse caminho. Para transformar criativamente o que era vivido como não metabolizável, o "chiclete mascado", em algo digerível. E, mais importante ainda, ser capaz de sentir-se e vivo e descobrir um pai que carregou vida dentro de si, para só então poder "deixá-lo morrer" (Batistelli, 2010, p.161). 
De qualquer forma, quando se trata da presença da ameaça de morte de uma pessoa importante, neuróticos e psicóticos podem sentir, em amplo espectro de possibilidades, algum nível de dor psicológica e desorganização, sendo muito comum a dor intensa e aguda, da ordem do insuportável. A experiência pode ser sentida como uma agonia impensável que remete à desproteção, a não integração, ao deixar-se cair. Uma dor em coloridos gélidos e apavorantes que, em algum momento, o sujeito já vivenciou pontual ou cronicamente.

Como dito no início deste subitem, o ser humano é o único ser que se cria, que cria o mundo e que se percebe como finito. Este ser compreende que a morte, sua e do outro, faz parte de seu destino. Para Winnicott, o homem e a mulher têm uma tendência inata à integração, e passarão a vida em desenvolvimento emocional, lidando com o ambiente e suas complexidades. Os constructos de Winnicott apresentado aqui são úteis para pensar os processos de luto. Os modos de ser/estar e relacionar-se com o mundo, bem como a experiência da primeira morte, a experiência relacionada à continuidade do ser frente à intrusão da morte, a construção da capacidade de ter "fé em...", as angústias impensáveis têm relação íntima com o modo do sujeito lidar com a ameaça de morte de um ente querido. Passo agora à segunda parte desta pesquisa que está relacionada à clínica e ao manejo do luto antecipatório. Nela trarei algumas contribuições importantes de Winnicott que trazem luz para este tipo de intervenção em luto antecipatório em grupo familiar. 


\section{PRÁTICA}

O luto antecipatório, como dito anteriormente, não foi um fenômeno especificamente tratado por Jung, mas o arcabouço teórico e técnico pode auxiliar na construção de uma clínica que tem como foco o cuidado durante processo de enlutamento. A Parte II do presente trabalho será então dedicada à parte clínica. Em um primeiro momento dos pilares, tratarei das técnicas relacionadas à clínica junguiana para atendimento individual, e quando ela acontece em contextos de luto. Em seguida, apresentarei a clínica dedicada ao atendimento em grupo dentro da perspectiva da Psicologia Analítica. Num segundo momento, trarei as contribuições da perspectiva de Winnicott, apresentando suas orientações sobre a clínica relacionada ao setting terapêutico e ao holding para cada fase do desenvolvimento. Para finalizar esta segunda parte da pesquisa, apresentarei as algumas orientações técnicas para o atendimento domiciliar em grupo de familiares que estejam em luto antecipatório.

\subsection{A clínica da Psicologia Analítica}

No presente capítulo, pretendo apresentar mais especificamente a clínica dentro da perspectiva da Psicologia Analítica. Aqui serão apresentadas algumas especificações desta escola teórica em sua modalidade de atendimento individual e na clínica realizada em grupo. Tratarei aqui de diretrizes, pilares importantes e, também, apresentarei algumas das técnicas utilizadas. E para completar a noção de como a clínica é realizada dentro de contextos de luto, trarei alguns exemplos de como pode ser realizado tal manejo.

\subsubsection{Processo terapêutico individual e o manejo de pacientes em luto}

A psicoterapia junguiana está voltada ao autoconhecimento, ao processo de individuação e tem um amplo alcance de atuação, podendo ser utilizada para auxiliar pacientes que estejam em momento díspares, inclusive em situações de crise. Ou seja, a clínica junguiana tem um amplo alcance, podendo ser aplicada junto a pessoas com estruturas neuróticas e, também, pode ser utilizada com pessoas cindidas e/ou psicóticas. 
Em outras palavras, a psicoterapia junguiana pode beneficiar tanto neuróticos quanto psicóticos, em amplo espectro com o objetivo de aproximar o paciente do próprio si mesmo (Jung, 2013a, 2013c; Silveira, 1992, 2018) .

Outro ponto importante para ser apontado neste início é que na clínica analítica o paciente pode se encontrar em qualquer momento da vida, se beneficiando amplamente desta abordagem, seja na infância, adolescência, idade adulta, velhice. Nas palavras de Von Franz, "o processo de individuação é, na verdade, mais do que um simples acordo entre a semente inata da totalidade e as circunstâncias externas que constituem o seu destino" (von Franz , 2008, p. 214). Nesse sentido, na terapia o eixo ego-self estará sempre sendo cuidado, para o encontro com o si mesmo. Terapeuta e paciente estão atentos às orientações do self, que acontecem por meio de suas mensagens simbólicas, que emergem, geralmente, do inconsciente:

Por vezes, sentimos que o inconsciente nos está guiando de acordo com um desígnio secreto. É como se algo estivesse nos olhando, algo que não vemos, mas que nos vê talvez o Grande Homem que vive em nosso coração e que através dos sonhos, nos vem dizer o que pensar a nosso respeito . . Tal como a árvore, devemos nos entregar a esse impulso quase imperceptível e, no entanto, poderosamente dominador - um impulso que vem do nosso anseio por uma autorrealização criadora e única. É um processo no qual é necessário, repetidamente, buscar e encontrar algo ainda não conhecido por ninguém. Os sinais orientadores ou impulsos vem não do ego, mas da totalidade da psique: o self. (von Franz, 2008, p. 216)

Para aproximar a clínica individual do processo de luto, apresento brevemente o trabalho de Rodrigues (2009) . O autor traz o exemplo da atuação clínica junto a pacientes em crise, especificamente em luto por perda de membro, devido ao fato de terem sido acometidos por amputações. Este tipo de acometimento promove processos de crise profunda na qual o terapeuta terá a função de acolher e auxiliar no processo de ressignificação do corpo, na busca da nova identidade, compondo novos caminhos no processo de individuação.

Em contextos gerais, a psicoterapia pode ser utilizada para diversas demandas, desde aquelas advindas de quadros complexos, como acontece com pacientes cindidos em uma esquizofrenia, até demandas relacionadas a casos nos quais é preciso realizar, como Jung diz, "reparações ritualísticas". Estas reparações fazem parte de um esforço de articulação entre a tomada de consciência e o material inconsciente constelado nos complexos. Interessante dizer aqui que, para Jung (2013h), o ser humano civilizado de modo geral possui graus elevados de dissociabilidade, permanecendo preso à perspectiva racional, ao pensamento, ao conhecimento, não permitindo-se aos riscos de aprofundarse no campo dos sentimentos, intuições nem nas próprias demandas. 
Nesse sentido, o meio em que vivemos, na modernidade, em geral não acolhe demandas mais profundas dos seres humanos em nome de uma normatividade. Ao longo do desenvolvimento humano, muitos aspectos da personalidade são reprimidos em nome dessa ordem normativa. Nesse sentido pode-se chegar ao ponto de termos uma vida externamente adequada, organizada, cumprindo todas as "obrigações" sociais. Contudo um alto preço da alma começa a ser cobrado, pois o resultado disso é o aparecimento de sintomas, seja pelo sentimento de uma vida interna vazia, falta de sentido, sensação de se estar perdido, conflitos graves com as pessoas do entorno, ansiedade, depressão, transtornos alimentares, de sono e muitos outros. Jung não orienta focar-nos apenas nos sintomas, já que estes são somente reações da alma frente ao desalinhamento com o próprio processo de individuação. Jung não propõe cura, mas propõe a realização de uma transformação e a busca pelo retorno ao si mesmo, como dito anteriormente. O objetivo da psicoterapia é auxiliar este resgate para que o indivíduo possa ser ele mesmo integrando os aspectos inconscientes ao consciente, trazendo equilíbrio entre o mundo de fora e o mundo de dentro.

Importante frisar que na clínica da Psicologia Analítica não se trabalha com o objetivo de fechar diagnósticos e solucionar sintomas, porque estes são entendidos como elementos de sombra e são apenas parte dos processos psíquicos que serão simbolicamente analisados. Para Jung, os diagnósticos são importantes para nortear o terapeuta, mas não são interessantes quando são tomados ao pé da letra ao ponto de restringir a escuta do paciente. De acordo com Rodrigues (2009), uma mudança importante advinda de situações adversas, como acidentes, doença etc., pode propiciar, mesmo por vias bastante dolorosas, a ampliação da consciência. As queixas trazidas como sintomas de pânico, depressão, ansiedade, ou dor psicológica do luto em si, deverão ser acolhidas pelo psicólogo analítico como uma reação subjetiva e idiossincrática da psique, e não apenas como sintomas. Nesse sentido, o psicoterapeuta deve estar atento a todas as movimentações trazidas ao consultório, como a paulatina integração dos aspectos da sombra que emergem com a adversidade imposta pela vida, retomada do caminho construído pelo self a partir da assimilação criativa da situação vivenciada e movimentos de apropriação da persona relativa a nova realidade.

Ainda com relação aos sintomas, é importante dizer que Jung dá importância ainda maior à história do paciente, suas humanidades, sua constituição e peculiaridades pessoais. O ponto chave é a narrativa própria que o paciente compartilha, é conhecer o processo particular de um determinado estado psíquico. O diagnóstico não resolve os 
impasses do sofrimento humano; ajuda na compreensão do caso, mas tem caráter insuficiente no desenvolvimento da terapia. A ênfase não é a busca do rótulo patológico, mas auxiliar a autocompreensão e autonomia (Jung, 2001; 2013c). Para Jung “. . . o médico deve deixar aberto o caminho individual da cura, e neste caso o processo terapêutico não acarretará nenhuma transformação da personalidade, mas será um processo, chamado de individuação [grifo do autor]" (Jung, 2013a, p. 21).

O tratamento consiste em criar pontes comunicantes (psicopômpicas), auxiliando a identificação de conteúdo polarizados na fala do paciente, a fim de trazer para a consciência tais conteúdo. Este exercício tem o intuito de ampliar o que a consciência conhece. Aspectos da sombra são olhados, e uma observação profunda é incentivada pelo terapeuta, com o objetivo de integrar parte da sombra à consciência, trabalho que será melhor descrito ao longo do texto.

O trabalho individual para Jung tem o objetivo de tratar as dificuldades existentes em indivíduos que já tentaram, mas ainda não conseguiram se haver com suas dificuldades. A psicoterapia junguiana busca auxiliar o ser humano na busca de si mesmo, despertando seu curador interno. Como dito anteriormente, orienta-se que este trabalho seja realizado sem hierarquias entre terapeuta e paciente em um exercício dialético, valorizando o olhar simbólico e tendo como orientador, como disse anteriormente, o processo de individuação do paciente.

Jung define o trabalho psicoterapêutico como um exercício dialético, não podendo ser definido como um método, já que cada paciente requer um tipo próprio de intervenção. O paciente traz afetos, cenas, imagens, de qualquer parte da vida, e o terapeuta irá, por meio de um olhar simbólico, analisar as questões trazidas de modo a refletir e compreender junto com o paciente tais questões com o intuito de buscar compreender o que tem carregado à situação de afetos que estão difíceis na lida. Aos poucos, o paciente vai compreendendo seu modo de funcionamento e, entrando em contato com as situações, e com os "carimbos" externos, verdades externas impregnadas, dores, conceitos ao qual foi sendo impregnado durante a existência, na busca da compreensão e integração dos aspectos relegados à sombra, que podem ser imensamente potentes e criativos no processo de transcender para um terceiro caminho.

Na rotina do trabalho, o paciente verbaliza as questões que deseja tratar e/ou o que lhe está causando aflição e, junto com o psicoterapeuta, confronta novas formas de existir, percebendo e deixando que os símbolos ecoem os sentidos que estão além de sua compreensão. Além de compartilhar as histórias vividas, os pensamentos e os 
sentimentos, ele também compartilha imagens simbólicas que emergem de histórias, sonhos, músicas etc. Estas, por sua vez, são validadas enquanto pontes de uma comunicação entre inconsciente e consciente, e têm um poder terapêutico e profilático (Parisi, 2009).

$\mathrm{O}$ face a face no setting terapêutico revela a postura interativa no processo. $\mathrm{O}$ analista junguiano fala, intervém, mas não em termos de conselhos, explanações teóricas, ou julgamentos. O analista trata por um outro viés. Se o objetivo é a psique, ele utilizará de sua experiência e conhecimentos para tratar das questões essenciais da vida. Neste referencial teórico, o psicoterapeuta não fica na posição de seguir o paciente. Ele também intervém ativamente, seja acolhendo, pontuando e auxiliando na reflexão junto ao paciente (Jung, 2006, 2013a).

Para Jung, na psicoterapia ocorre uma interação entre o sistema psíquico do paciente e do terapeuta, em busca do caminho mais alinhado ao que é fundamental, inerente ao paciente. Nas palavras do autor, a psicoterapia:

... se trata de um tipo de procedimento dialético, isto é, de um diálogo ou discussão entre duas pessoas. Originalmente a dialética era a arte da conversação entre os antigos filósofos, mas logo adquiriu o significado de método para produzir novas sínteses. A pessoa é um sistema psíquico, que, atuando, sobre outra pessoa, entra em interação com outro sistema psíquico. (Jung, 2013a, p. 13)

Sendo assim, é essencial ter cada caso como novo e único (Jung, 2013a). O cuidado que Jung tem com o encontro terapêutico está relacionado a uma postura ética. O autor parte do princípio de que o paciente deve ser independente, e com o tempo tornará a ser o seu próprio terapeuta, com autonomia diante das questões da vida. Sendo assim, ele propõe que estar com o paciente requer uma relação simétrica, sem disputa de poder, ou de hierarquia de saber.

... não tenho condições de julgar a totalidade da personalidade que está lá à minha frente. Posso fazer declarações legítimas apenas a respeito do ser humano genérico, ou pelo menos relativamente genérico. Mas como tudo o que vive só é encontrado na forma individual, e visto que só posso afirmar sobre a individualidade de outrem, o que encontro em minha própria individualidade, corro o risco, ou de violentar o outro, ou de sucumbir por minha vez ao seu poder de persuasão. Por isso, quer queria quer não, se eu estiver disposto a fazer o tratamento psíquico de um indivíduo, tenho que renunciar a minha superioridade no saber, a toda e qualquer autoridade e vontade de influenciar. Tenho que optar necessariamente por um método dialético, que consiste em confrontar as averiguações mútuas. Mas isto só se torna possível se eu deixar ao outro a oportunidade de apresentar seu material o mais completamente possível, sem limitá-lo pelos meus pressupostos. (Jung, 2013a, pp. 15-16)

Nesse sentido, Jung compreende que as "técnicas", isoladamente, por si só, podem estar a serviço de não promover o procedimento dialético e do encontro analítico. Esse procedimento pode ser utilizado como defesa de um profissional ainda inseguro de uma 
relação verdadeira (Jung, 2013a). O risco de utilizar técnicas e métodos generalizadores e impositivos podem violentar o indivíduo, o que nada tem a ver com a proposta de Jung.

Outro pilar importante é o olhar antropológico e sociológico para o indivíduo. A Psicologia Analítica considera importantes, não apenas os aspectos individuais, mas também culturais em que o indivíduo está inserido. Ou seja, quando atende um cliente, o psicólogo junguiano não considera apenas seus aspectos individuais, mas também seu entorno para o compreender melhor. Com o passar do tempo é possível, inclusive, observar no paciente uma mudança na interação com o meio, sendo que o processo terapêutico irá influenciar também a relação com o mundo externo. A tomada de consciência durante o processo irá, dessa forma, ampliar o modo como o indivíduo pensa, e lida no aqui e agora. De acordo com Jung, "O método terapêutico da psicologia complexa consiste, por um lado, numa tomada de consciência, o mais completa possível, dos conteúdos inconscientes constelados, e, por outro, numa síntese dos mesmos com a consciência através do ato cognitivo" (Jung, 2013h, pp. 49-50).

Outra característica da clínica junguiana é o fato de não se buscar obstinadamente a causa da neurose na história do paciente para "desmontar" o mecanismo:

... neurose ou qualquer conflito psíquico depende muito mais da atitude pessoal do paciente, do que da história de sua infância. .. A tarefa da psicoterapia consiste em mudar a atitude consciente, e não em correr atrás de reminiscências submersas da infância. Uma coisa não é possível sem a outra, certamente, mas a ênfase deveria ser posta na atitude consciente do paciente. (Jung, 2013a, pp. 42-43)

A função do terapeuta na Psicologia Analítica não é apenas de auxiliar no alívio das tensões vivenciadas, mas ajudar no processo de identificação das polarizações que estão em conflito, facilitando as devidas interpretações, integrações, bem como a função transcendente. Como dito anteriormente, Jung aponta para o trabalho a partir da "escuta simbólica”.

O meu esforço consiste justamente em fantasiar junto com o paciente. Pois não é pouca importância que dou à fantasia ... O que viso é produzir algo de eficaz, é produzir um estado psíquico, em que meu paciente comece a fazer experiências com seu ser, um ser em que nada mais é definitivo nem irremediavelmente petrificado; é produzir um estado de fluidez, de transformação e de vir a ser. (Jung, 2013a, pp. 58-59)

De acordo com Widmer Costa Neto (2018) a atitude simbólica é imprescindível para ampliação da consciência, permitindo a integração do novo, que por vezes é percebido como algo perigoso, que nos ameaça. As imagens simbólicas são trabalhadas de diversas formas, como apontado anteriormente. Uma das técnicas é a ampliação dos sonhos - considerado por Jung o meio mais eficaz e rápido de acesso ao inconsciente; outras técnicas também utilizadas são a imaginação ativa que, juntamente com os sonhos, 
é tratada no exercício de ampliação simbólica. Jung estimula também como técnica a expressão gráfica, especialmente a pintura, na medida em que a demanda aparece. Se esta fosse espontânea, Jung incentiva o paciente a se desenvolver. Assim, ele pode sair de uma relação de dependência com o terapeuta para uma postura mais madura, adulta frente os próprios processos. Outras técnicas encontradas no tratamento analítico são o sandplay, calatonia, arteterapia, o trabalho com mitos, conto de fadas, dentre outras.

Durante o processo terapêutico, o material é colocado em foco. "Este 'diálogo' entre o ego (centro da consciência) e o inconsciente é condição básica do processo de individuação, em que os opostos são confrontados, surgindo um terceiro elemento que é a função transcendente" (Parisi, 2009, p.59), caracterizada como uma terceira forma de lidar com as questões que afetam o paciente. De acordo com Jung:

Por 'função transcendente' não se deve entender algo de misterioso e por assim dizer suprassensível ou metafísico, mas uma função que, por natureza, pode-se comparar com uma função matemática de igual denominação ... A função psicológica e 'transcendente' resulta da união dos conteúdos conscientes e inconscientes." (Jung, 2013c, p. 13)

Independente do público atendido e do local (consultório particular, hospital psiquiátrico, hospital geral), o ambiente psicológico deve ser acolhedor, de modo a possibilitar segurança para que o paciente adentre seus processos com profundidade. Como em um vaso alquímico hermeticamente fechado, terapeuta e paciente trabalham face a face, tendo o paciente na pessoa do terapeuta alguém que lhe evoca confiança e também projeções profundas (transferência) (Jacoby, 2011; Jung, 2013c).

O método construtivo de tratamento pressupõe percepções que estão presentes, pelo menos potencialmente, no paciente, e por isso é possível torná-las consciente. Se o médico nada sabe dessas potencialidades, ele não pode ajudar o paciente a desenvolvê-las, a não ser que o médico e o paciente dediquem conjuntamente um verdadeiro estudo a este problema, o que em geral, está fora de questão.

... Por isto, na prática é o médico adequadamente treinado que faz a função transcendente para o paciente, isto é, ajuda o paciente a unir a consciência e o inconsciente e, assim, chegar a uma nova atitude. Nesta função do médico está uma das muitas significações importantes de transferência: por meio dela o paciente se agarra a pessoa que parece lhe prometer uma renovação da atitude; com a transferência, ele procura esta mudança que lhe é vital, embora não tome consciência disto. (Jung, 2013c, pp. 18-19)

Jung (2013a, 2013k) considera que a falta de uma boa conexão com o paciente gera um tipo ruim de transferência e aconselha que, para evitar estes problemas, o terapeuta deverá ter uma atitude horizontal com relação ao paciente. No entanto, de um modo geral, Jung considera a transferência um obstáculo, e que o processo de cura ocorre apesar dela, já que temos os sonhos, por exemplo, como material para acessar o inconsciente do paciente. 
Jung confia no trabalho a quatro mãos, pois o paciente, ou melhor dizendo, o self do paciente é quem orienta as transformações e integrações necessárias no caminho da individuação ${ }^{18}$. O trabalho clínico tem como fim a realização do si mesmo, e este processo é construído tijolo a tijolo, não existindo mágicas ou atalhos.

O procedimento é necessariamente muito trabalhoso e demorado. É certo que se fazem muitas tentativas no sentido de abreviar ao máximo a duração do tratamento, mas não se pode afirmar que os resultados tenham sido animadores. Porque quase sempre as neuroses são produto de uma evolução defeituosa, que demorou anos e anos para se formar, e não existe processo curto e intensivo que o corrija. O tempo é, por conseguinte, um fator insubstituível na cura. (Jung, 2013a, p. 35)

Na clínica junguiana, o olhar simbólico é um dos pilares mais importantes e, por isso, é bastante usado o trabalho com sonhos e outros materiais expressivos. Além de um levantamento verbal sobre a vida do paciente, o terapeuta poderá utilizar técnicas auxiliares como dito anteriormente. Segundo Jung, o material inconsciente está, em geral, em desacordo no que se trata de "conteúdos e tendências" (Jung, 2013a, p. 13), o que se configura como um ponto de dificuldade para a compreensão dos processos psíquicos. Nesse sentido, é importante tratar desses conteúdos. A seguir, apresentarei brevemente duas técnicas utilizadas no atendimento analítico: os sonhos e o uso dos materiais expressivos.

Os sonhos são expressões de caráter simbólico, como tantas outras que se apresentam ao ego para serem compreendidas e cumprir as funções que o símbolo desempenha na vida psíquica, quais sejam: a função compensatória de autorregulação do sistema psíquico e a função transformadora que se evidencia na possibilidade e necessidade de transformação de elementos inconscientes. (Jung, 2013a, 2013c; Penna, 2014).

De acordo com Penna (2014), os sonhos são criados na interação entre as polaridades tensionadas consciente/inconsciente. Tal situação revela o conflito atual do processo de individuação do sonhador. De acordo com Jung, as imagens são autônomas, originadas do inconsciente, e têm uma função exata para comunicar os processos internos. O paciente é convidado a ampliá-lo entrando em contato com as imagens apresentadas no sonho. Neste processo, o sonhador é convidado a perceber o que sente, pensa, intui perante os símbolos, em um trabalho cuidadoso e consistente. As comunicações

\footnotetext{
${ }^{18}$ É preciso pontuar que apesar dos princípios gerais da Psicologia Analítica, as diferentes escolas pósjunguianas possuem diferentes ênfases o que origina posturas, interpretações e análises diferenciadas na clínica.
} 
inconscientes podem estar relacionadas ao processo compensatórios do processo psíquico.

A função compensatória da atividade onírica nem sempre é evidente, mas para perscrutála é sempre necessário um conhecimento razoável da psique do sonhador, sobretudo das circunstâncias atuais de sua vida existencial. Por vezes o sonho reafirma uma atitude da consciência, como se colocasse uma lente de aumento para que o ego se veja espelhado pelo sonho. Tal expediente da psique parece ter a função de chamar a atenção da consciência para algo que esteja sendo pouco valorizado por ela, e nesse sentido reside, de certa forma, a função compensatória do sonho. (Penna, 2014, p. 118)

De acordo com a autora, o terapeuta deve se concentrar na observação do padrão arquetípico para conseguir averiguar o tema central, ou melhor dizendo, o núcleo arquetípico. É um processo realizado na interação direta com o paciente, já que o terapeuta precisa da tradução advinda do sonhador que o orienta em sua análise:

. . . o processamento simbólico do sonho começa pelas informações e associações fornecidas pelo paciente às nossas perguntas. A nós cabe formular as melhores perguntas possiveis para que a transcrição, tradução e compreensão das imagens oníricas sejam encaminhadas da melhor forma possível para uma aproximação gradual do sentido e do significado contido no sonho. (Penna, 2014, pp.116-117, grifo da autora)

É importante que o ego seja confrontado com os elementos novos e desconhecidos. O sonho apresenta sempre uma transformação rumo à totalidade. Neste sentido, o terapeuta passa a trazer luz às questões compensadas nos sonhos, de modo que o paciente traga para a consciência o que está sendo comunicado pelo inconsciente como aspectos pouco vividos, sentidos em vigília.

De acordo com Parisi,

. . . a confrontação com as figuras do inconsciente se dá a partir do ego, ao mesmo tempo permitindo que o inconsciente também se expresse. Isto dá condições de que o paciente desenvolva certa autonomia para lidar com seu próprio inconsciente, que é um dos objetivos propostos por Jung. Mas, não basta a representação das imagens, acrescenta, é necessário compreendê-las a fim de que sejam integradas à consciência. Em relação a esta compreensão, entretanto, há ressalvas. Ainda no ensaio sobre a função transcendente Jung (1958/2000a, p.17) alertou para o perigo de se supervalorizar uma compreensão intelectual sobre o conteúdo do material produzido 'o que faz com que se perca o caráter essencialmente simbólico do objeto’. (Parisi, 2009, p.60)

Como apontado anteriormente, os sonhos para os junguianos têm sentido e significado e, a partir da análise, pode-se perceber que os símbolos contidos neles têm aspectos coletivos e pessoais. É importante apontar que existem diferenças entre as imagens de caráter pessoal e de caráter impessoal. Jung (2013j) aponta que imagens de caráter pessoal remetem aos conteúdos do inconsciente pessoal e da experiência consciente e que as imagens de caráter impessoal são aquelas que se referem às imagens primordiais. De acordo com Vasconcellos e Giglio (2007): 
. . . Nessa perspectiva, ele define o fenômeno imagético como "uma expressão concentrada da situação psíquica como um todo", distinguindo-o de qualquer manifestação patológica (onde costuma ocorrer distorção da realidade), sendo um processo interno. A expressão imagética, portanto, agrega apenas conteúdos do inconsciente constelados naquele momento, visto que a seleção dos conteúdos relevantes e irrelevantes à formação da imagem é um processo consciente. Quanto aos arquétipos, esses apresentam certa autonomia e carga energética que atrai conteúdos do consciente que lhes revestem com roupagens adequadas à época e à circunstância pela qual são evocados. São, portanto, 'elementos estruturais numinosos' que dão a forma para que conteúdos do consciente se moldem e, assim, possam tornar-se perceptíveis. Dessa maneira, considerando o limiar entre inconsciente coletivo, inconsciente pessoal e consciente, vislumbramos a formação da imagem simbólica. Aliás 'nunca se pode encontrar o arquétipo em si de maneira direta, mas apenas indiretamente, quando se manifesta no símbolo ou no sintoma ou no complexo' (Jacobi, 1995, p.73). Portanto é importante destacar que arquétipo e símbolo não são conceitos equivalentes. $\mathrm{O}$ arquétipo é o centro energético que poderá ser constelado ao emergir na forma de símbolo. Esse último, entretanto, requer um esboço arquetípico, exercendo função transformadora da energia psíquica. (p. 378)

$\mathrm{O}$ arquétipo tem como característica o dinamismo e a impregnação de energias

ligadas a sentimentos, emoções, sentidos. Sendo assim, os conteúdos relacionados não podem ser interpretados sem a tradução do paciente, não pode ser um processo arbitrário. Esse diálogo entre inconsciente e consciente por meio dos símbolos é fértil e imprescindível para a integração dos aspectos apartados para o mundo sombrio, inconsciente. É importante esclarecer que Jung recomenda a análise da sequência de imagens, e não sonhos isolados. Os sonhos são interpretados, e nesse exercício é dada atenção à sucessão de imagens e aos elementos que se repetem:

No ponto em que hoje estão os nossos conhecimentos, parece que o impulso vital, que se exprime na construção e na conformação individual de um ser vivo, gera um processo no inconsciente, ou é o próprio processo. Este, à medida que se torna parcialmente conscientizado, é representado por uma sequência de imagens, comparável à sucessão rítmica da fuga musical. Pessoas naturalmente dotadas para a introspecção são capazes de perceber, sem maiores dificuldades pelo menos alguns fragmentos dessa sequência de imagens autônoma e automática. Geralmente isto se dá em forma de impressões visuais da fantasia. No entanto, essas pessoas cometem o erro frequente de pensar que foram elas mesmas que produziram essas fantasias, quando na realidade elas simplesmente thes ocorreram espontaneamente. Quando o fragmento de fantasia adquire caráter obsessivo, o que não é raro, a sua involuntariedade já não pode ser negada. Exemplo disso são as melodias que não nos saem da cabeça, ou as ideias fóbicas, ou os chamados tipes [sic] simbólicos. Mais próximos das sequências inconscientes de imagens estão os sonhos. Muitas vezes, quando examinados em séries extensas, podemos identificar, com surpreendente clareza, a continuidade do fluxo inconsciente de imagens. A continuidade manifesta-se na repetição dos chamados motivos. Estes podem referir-se a pessoas, animais, objetos ou situações. Portanto, a continuidade da sequência de imagens é expressa pelo fato de o motivo em questão sempre reaparece numa longa série de sonhos. (Jung, 2013a, p. 22)

Os motivos são temas contínuos originados do inconsciente. Nesse sentido, ao olhar as sequências, pode-se descobrir o que essas imagens estão indicando. A 
interpretação deve sempre levar em conta não apenas o viés racional, mas também simbólico. Os motivos ao longo de muitos sonhos podem ser substituídos, levando a outras imagens que aparecem destinadas a indicar como está o processo de individuação, como relata Jung a seguir:

As ideias básicas de todos os motivos são representações plásticas de caráter arquetípico, isto é, imagens primordiais, simbólicas, sobre as quais a mente humana se edificou e se diferenciou. Estes protótipos são difíceis de definir, para não dizer vagos, toda versão intelectual demasiadamente tacanha lhe rouba algo de sua amplitude. Não se trata de conceitos científicos, necessariamente isentos de equívocos na interpretação, mas de intuições originárias, extremamente genéricas da mente primitiva, que nunca designam conteúdos específicos. São importantes, porque se relacionam com a grande variedade de coisas. (Jung, 2013a, p. 23)

Após esta pequena explanação do trabalho com os sonhos, passo agora a apresentar o trabalho com os materiais expressivos, com base na Psicologia Analítica. De acordo com Urrutigaray (2011), a Arteterapia no Brasil tem como pilar o trabalho pioneiro de Nise da Silveira (1905-1999). A referida psiquiatra encontrou na Psicologia Analítica um manancial e uma parceria que a auxiliou a pensar e cuidar dos pacientes em sua prática clínica (e pesquisa) com esquizofrênicos:

O mais importante acontecimento ocorrido nas minhas buscas de curiosa dos dinamismos da psique foi o encontro com a psicologia junguiana. Jung oferecia novos instrumentos de trabalho, chaves, rotas para distantes circum-navegações. Delírios, alucinações, gestos, estranhíssimas imagens pintadas ou modeladas por esquizofrênicos, tornavam-se menos herméticas se estudadas segundo seu método de investigação. E também não lhe faltava o calor humano de ordinário ausente nos tratados de psiquiatria. (Silveira , 2018, p.13)

Apesar de existirem diferenças entre a "Terapia Ocupacional" no trabalho de Nise, e a "Arteterapia" de base junguiana, tratarei de como ambas cuidam do fenômeno bem como dos benefícios da utilização dos materiais artísticos, tanto no tratamento de pacientes neuróticos quanto em pacientes psiquicamente cindidos. Foge ao escopo do presente trabalho apresentar as diferenças entre "Terapia Ocupacional" e a "Arteterapia", bem como as diferenças entre as escolas da própria "Arteterapia" (Urrutigaray, 2011; Silveira, 1992, 2018).

Silveira (2018), ao trabalhar com pacientes que desenvolveram esquizofrenia, afirma que a expressão de imagens pela arte, em um contexto acolhedor e que lhes inspire confiança consistente e diária, é altamente estruturante. O processo terapêutico consiste em deixar exprimir sem censuras as imagens do inconsciente.

O atelier de pintura era inicialmente apenas um setor de atividade entre os vários outros setores. . . Mas aconteceu que desenho e pintura espontâneos revelaram-se de tão grande interesse científico e artístico que esse atelier cedo adquiriu posição especial. Era surpreendente verificar a existência de uma pulsão configuradora de imagens 
sobrevivendo mesmo quando a personalidade estava desagregada. Apesar de nunca haverem pintado antes da doença, muitos dos frequentadores do atelier, todos esquizofrênicos, manifestavam intensa exaltação da criatividade imaginaria, que resultava na produção de pinturas em número incrivelmente abundante, num contraste com a atividade reduzida de seus autores fora do atelier, quando não tinham mais nas mãos os pincéis. . . . Pintar seria agir. Seria um método de ação adequado para defesa contra a inundação pelos conteúdos do inconsciente. (p. 15) $\mathrm{O}$ atelier de pintura me fez compreender que a principal função das atividades na Terapêutica Ocupacional seria criar oportunidade para que as imagens do inconsciente e seus concomitantes motores encontrassem formas de expressão. Numa segunda etapa viram as preocupações com a ressocialização. (Silveira, 2018, pp. 15-16)

No mesmo sentido, a Arteterapia consolida seu trabalho, tendo como objetivo permitir que o que foi produzido pelo paciente (escultura, pintura, movimento corporal e outros) possa ser olhado e elaborado, a fim de diminuir as consequências perigosas da cisão entre o que é consciente e inconsciente, e também restaurar a comunicação entre eles.

O trabalho com Arteterapia visa exatamente permitir a ação mental, ou a elaboração, com o intuito de extrair a emoção (afetividade, sentimento) que se encontra "oculta", como ideia na imagem formada, a princípio, inexistente no sentido empírico. O assim chamado conteúdo ideal provido de coloração afetiva, como parte ainda inconsciente e presente na imagem criada, transmuta-se em realidade capaz de ser identificada, porque encontra um campo para ser materializado. (Urrutigaray , 2011, p. 29)

O trabalho com materiais expressivos faz com que algo se transforme no paciente, independente se este apresenta sintomas neuróticos ou psicóticos, já que ele exercita a possibilidade de ao criar algo do original (por exemplo, mexendo com uma argila inerte), podendo, desse modo, se recriar, criar novas expressões virtuais e outra relação com seu ato criativo. $\mathrm{O}$ ser que expressa torna-se alguém legitimado.

De acordo com Urrutigaray (2011), o arteterapeuta estimula a criação e a conclusão da obra. Durante este processo, o profissional deve observar o percurso da criação, as reações, as falas verbalizadas. Nesta modalidade, é importante que o profissional conheça as técnicas, para ter intimidade com o manuseio do material, e ter a noção exata do que objetiva ao aplicar uma técnica específica (alcance e proposta). Para a autora, a arteterapia

Revestida de um valor técnico, visa, por meio da mediação de instrumentos plásticos, à expressão ou à comunicação de representações como as fantasias e os sentimentos, possibilitando, assim, um espaço para a liberação de energias psíquicas, favorecendo a expressão posterior à criação estabelecida em palavras daquilo que antes não tinha nem nome ou identidade e nem sequer lugar ou espaço para manifestar-se. Tem como finalidade a atualização da imaginação transformadora, pela qual as imagens manifestamse de forma ativa, conectando o sujeito com novas modalidades vivenciais presentes nas imagens criadas. (Urrutigaray, 2011, pp. 26-27) 
$\mathrm{Na}$ esquizofrenia, o ego fraco ou fragilizado é derrotado violentamente pelas invasões do inconsciente, e assim o mundo externo é desorganizado com muita intensidade, como em um terremoto, afirma a psiquiatra Nise da Silveira (2018). Silveira (1992) atribui grande importância ao trabalho espontâneo com materiais expressivos por parte dos pacientes (sem interferências dos técnicos), e à imagem produzida em si mesma. Quando o paciente está imerso no caos psíquico e consegue dar forma às emoções, bem como representar o que o está transtornando, tem oportunidade de esvaziar a potência (pelo menos em partes) destas experiências internas.

Para Silveira, a produção das imagens modifica sensivelmente a organização psíquica e, portanto, tem caráter transformador. De acordo com Silveira (2018), esta experiência com os materiais artísticos permite que seja visto o que está “invisível”. Para ela, "E é justamente em atividades feitas com as mãos, que, com bastante frequência, se revela a vida dessas 'sementes criativas'. Jung escreve: 'Se houver alto grau de crispação do consciente, muitas vezes só as mãos são capazes de fantasia'.” (Silveira, 2018, pp. 110-111). A autora orienta que o profissional estude os símbolos expressos nas séries de imagens, a fim de compreender esta nova linguagem, não com a intenção de apenas racionalizar o que é expresso, a real intenção é desvendar os sentidos revelados daquela psique adoecida.

De acordo com Silveira (2018), a linguagem simbólica transforma-se e tem caráter transformador. O profissional deve se esforçar em aprender esta nova linguagem, não em sentido meramente intelectual, como orientado por Jung. É preciso ir ao encontro do paciente para compreender o que está sendo trazido com esta linguagem, mas também é necessário que o profissional se aprimore nos estudos paralelos na mitologia, arqueologia, história da arte e das religiões para dar conta da compreensão ampliada destes conteúdos que por vezes são originados de camadas muito profundas do inconsciente coletivo: "Mas eu não examinava as pinturas dos doentes que frequentavam nosso atelier sentada no meu gabinete. Eu os via pintar. Via suas faces crispadas, via o ímpeto que movia suas mãos.” (Silveira, 2018, p.19)

Para Silveira (2018), a oferta de materiais expressivos tem o intuito de ajudar o paciente a entender melhor os conteúdos invasores (e arcaicos). Na psicose estes conteúdos emergem violentamente (das instâncias mais profundas da psique), e não são uma realidade concreta, mas um material simbólico passível de elaboração, ainda que esta tarefa de compreender seja difícil e carregada de sofrimento. 
Em decorrência do avassalamento do consciente pelo inconsciente, o indivíduo perde o contato com a realidade e desadapta-se ao meio onde vive. De acordo com Silveira, este paciente era internado nos tristes lugares que são as instituições psiquiátricas. O ateliê de pintura em sua experiência apresentava-se como um oásis, se o doente tivesse a liberdade de exprimir-se livremente e aí relacionar-se afetivamente com alguém que o aceitasse e procurasse entendê-lo na sua peculiar forma de linguagem. A arte teria então o papel importante, pois através dela seria possível retirar-se do que Silveira chamou de redemoinho perturbador, a fim de conquistar um oásis, um refúgio.

O trabalho com o material expressivo segue o mesmo trato do trabalho com os sonhos no sentido de que os trabalhos criados pelos pacientes são melhor compreendidos em série. Nos sonhos e nas produções artísticas é possível averiguar uma continuidade no fluxo de imagens do inconsciente. Nos trabalhos de pacientes psicóticos, os conteúdos do inconsciente aparecem tumultuados e as imagens são mais estranhas e arcaicas se comparadas com as imagens dos sonhos. Contudo, se analisadas em série é possível perceber um fio condutor, um sentido. As imagens são arcaicas e emergem das estruturas mais profundas da psique, mas não são patológicas em si, o que é patológico é a vulnerabilidade, ou mesmo a falência do poder do ego em controlar os processos. Assim, para Silveira (2018), os materiais expressivos têm muita importância terapêutica, as imagens desenhadas ou pintadas no atelier de pintura tornam-se passíveis de análise. Mesmo sem ter com clareza as profundas significações, há uma transformação no paciente. A diferença entre o trabalho entre neuróticos e psicóticos é enorme, já que reunir interpretação intelectual e afetiva é muito difícil para os psicóticos.

\subsubsection{Manejo da terapia individual junto a pacientes em luto}

Vasconcellos e Giglio (2007) apresentam que a utilização das técnicas expressivas com base na Psicologia Analítica têm sido aplicadas não somente em contextos de saúde mental, mas também em hospitais gerais e clínicas que têm como foco o atendimento de pacientes que apresentam doenças crônico-degenerativas. As autoras também apresentam a experiência de atuação junto a pacientes fora de possibilidade terapêutica de cura, e também em terminalidade. Segundo elas, o trabalho arteterapêutico permite a ampliação da consciência e o acolhimento de processos muito dolorosos que permeiam tal contexto: “. . . no espaço arteterapêutico, trabalhamos com a expressão simbólica através das imagens elaboradas nas produções artísticas (valorizando a representação gráfica e 
pictórica), sendo externalizadas vivências de sofrimento e morte sem que seja necessário nomeá-las." (Vasconcellos e Giglio, 2007, p.381).

A clínica em cuidados paliativos pode ser realizada com o paciente, mas também com os familiares. O ponto mais importante é que a intervenção seja humanizada, visto que, quando existe uma morte anunciada, todo o entorno é afetado. A seguir, as autoras apresentam reflexões sobre o trabalho com os pacientes em cuidados paliativos:

$\mathrm{Na}$ área de cuidados paliativos, existem algumas peculiaridades do trabalho arteterapêutico em função das características da população atendida, sendo alcançados alguns resultados bastante expressivos. Com relação a esse tema, Woods (1998) destaca que essa intervenção pode objetivamente auxiliar o paciente a compreender sua real situação, enfrentar mudanças relacionadas à imagem corporal, amenizar a dor emocional pertinente ao processo do adoecer e do morrer; aumentar sua autonomia e confiança, fortalecendo algumas habilidades para enfrentar a situação de doença, facilitar a expressão de sentimentos e fortalecer a relação com a equipe de saúde. (Vasconcellos e Giglio, 2007, p.380)

Ampliando essa perspectiva, passo agora a apresentar uma série de trabalhos relacionados ao contexto do luto, mas não necessariamente do luto antecipatório. Para Gambini (2005), “nossa civilização contemporânea criou defesas maníacas contra a companhia da morte. Nós que trabalhamos com a psique sabemos que o reprimido pode estar soterrado sob uma placa espessa de cimento, mas não desapareceu” (p. 143). A citação do autor coloca em destaque uma importante noção nos contextos do luto: assegurar uma comunicação desinterditada para que haja a possibilidade de uma relação interpsíquica e, no caso do presente trabalho, intrafamiliar mais saudável.

... a morte como companheira deve ser acolhida e de forma alguma evitada, porque é precisamente ela e mais ninguém quem de fato nos ensina a viver. Ela é a grande mestra da vida porque nos faz sentir o tempo correndo na alma, nos faz ouvir estarrecidos o som e a fúria de nossas ilusões mais vãs. Paradoxalmente, a imagem do término absoluto da vida terrena é que nos habilita a viver a vida em sua possível plenitude. (Gambini , 2005, p. 143)

Para o autor, a presença da morte pode dissolver parte do ego e da persona que passa a ser inútil frente a sua magnitude no processo de desenvolvimento psíquico. $\mathrm{O}$ impacto gerado pelo contato com a morte é ainda difícil de ser manejado por ser um tabu na sociedade, e pouco trabalhado na formação profissional nas universidades. Apesar da morte ser uma parte pertencente ao processo de desenvolvimento humano, ela ainda é pouco tratada nos cursos universitários, inclusive nos cursos de Psicologia, necessitando, nesse sentido, de formação adicional para que o profissional seja capaz de atender certas demandas (comunicação pessoal Maria Júlia Kovács, 6 de junho de 2020).

No processo terapêutico, o profissional de psicologia deve se esforçar para auxiliar na integração deste tema tabu, pois não tratar desta demanda pode ser altamente perigoso, 
como apontado por Gambini (2005). À morte são atribuídos os piores sentimentos, sendo ela um depositário da sombra da sociedade que, por sua vez, mascara-se nas regras dos "bons costumes" e do bom senso, no qual o mais forte é o mais equilibrado e discreto em seus sentimentos. Assim, sob o ponto de vista da Psicologia Analítica, quanto mais reprimida, mais força a sombra tem. Esta força pode impactar patologicamente a saúde física, psíquica e social. Como dito anteriormente, as psicólogas e psicólogos precisam estar atentos ao processo de autorregulação da vida psíquica integrando as polaridades vida-morte, pois o inconsciente acusa que algo na sombra deve ser integrado.

Nesse sentido, é desejável que os conteúdos da sombra sejam aos poucos trazidos à consciência de forma que, ao ganharem expressão, encontrem canais criativos para tanto, amenizando a tensão energética que os criou. Nesse contexto, a palavra, os materiais expressivos, os sonhos, os mitos passam a ser instrumentos facilitadores desse processo ganhando papel fundamental. A psicoterapia em sua perspectiva simbólica tem a função de transformar o que está na sombra em parte integrante.

Esse movimento pode ser compreendido em duas instâncias: na instância intrapessoal e na instância interpessoal. Intrapessoal no sentido de que o processo terapêutico auxilia na integração consciente-inconsciente, contribuindo no processo de individuação. Interpessoal no sentido de transformar as comunicações "marginais", interditadas em conversas nas quais se inclui o que realmente se sente. Ouvir essas expressões, acolher as angústias e estimular a produção criativa positiva dos enlutados pode possibilitar o exercício de se repensar e se reconstruir dentro do processo vivenciado. Assim a vida intrapsíquica se modifica, o que acaba por refletir numa mudança na qual o indivíduo passa a se compreender melhor, se aceitar e melhorando as relações com o mundo, podendo caminhar de modo mais confiante e integrado. Sendo assim, temos muito material acerca da clínica junguiana e pós-junguiana que pode contribuir para o processo de criação das orientações aqui apontadas.

Além do trabalho com os pacientes em estado grave, ou fora de possibilidade de cura, temos estudos de terapeutas junguianos que se dedicaram ao trabalho com o luto dos sobreviventes no atendimento individual. Aqui apresentarei apenas alguns exemplos, como os trabalhos de Savage (1989) sobre luto de pais enlutados e mito; Byington, (2005) com o trabalho em contexto de luto patológico, e Catta-Preta (2012), que utilizou os sonhos na psicoterapia de uma mãe enlutada.

O primeiro estudo que irei apresentar é o trabalho realizado por Savage (1989) com pais adotivos e naturais, que sofreram perdas gestacionais ou de filhos pequenos. A 
autora escolheu trabalhar com o tema do aborto natural por ser, além de outros motivos, uma experiência dolorosa que evoca tristeza e sentimento de impotência:

... diferentemente de outras experiências que envolvem a perda de alguém, não há, no caso, nenhum 'relacionamento', no sentido extrapsíquico, a ser lamentado ... um aspecto da angústia humana que até agora tem permanecido ignorado: a influência da imagem simbólica e arquetípica sobre o apego e a separação. Lamenta-se o aborto natural não apenas pelo que foi, mas também pelo que poderia ter sido. (Savage, 1989, p.16)

A autora apresenta uma análise profunda a partir da Psicologia Analítica, e utiliza para tanto sua experiência profissional como psicóloga. Savage desenvolve com os pais a análise de sonhos e ampliações utilizando mitos para a integração no processo de perda. A gestação promove projeção da imaginação dos pais, quando o bebê morre, morre também certa noção de uma parte deles que não poderá ser concretizada no mundo.

É no inconsciente que os apegos criam raízes. Ao se revelar o mistério do relacionamento imaginário, isto é, as projeções do self sobre o filho que não nasceu, fica claro que relacionamentos mais simples não são compostos apenas por atributos funcionais premutáveis e por funções, mas que são unicamente vínculos pessoais gerados a partir do âmago da pessoa, e se constituem tanto num reflexo da alma individual como num acurado reflexo do outro. (Savage, 1989, p.18)

Savage (1989) aproxima o sentimento de revolta na busca pelo filho perdido com o mito de Deméter (deusa da agricultura, da fertilidade), que perde sua filha Perséfone para Hades (deus do mundo avernal, deus dos mortos). O rapto de Perséfone gerou uma tristeza desesperadora na mãe e uma calamidade para os humanos, pois, enquanto Deméter buscava obstinadamente sua filha, nenhuma semente brotou. Zeus precisou intervir, negociando por meio de Hermes que Perséfone ficasse com Hades apenas uma parte do ano, o que equivaleria a parte do outono e inverno, período em que Deméter se recolhe em tristeza e a terra se torna estéril. Segundo Savage (1989), muitos casais que perderam seus filhos vivenciam o ódio dilacerador durante o processo de luto, a projeção da raiva, considerada uma defesa psicológica que pode ser endereçada à própria família, ao cônjuge, a outras crianças saudáveis, contra si mesmos, contra Deus (ou qualquer aspecto da espiritualidade) etc.

O ataque de Deméter, internalizado e, desse modo, transferido psicologicamente, é não-regenerativo. Autorizada a seguir o próprio curso tempestuoso e livre de quaisquer coibições, internas e externas, essa revolta culmina em consequências calamitosas, tanto para o indivíduo como para quantos os rodeiam. (Savage, 1989, p. 99)

A interação do trabalho com o casal enlutado pode auxiliar na melhoria da desinterdição das comunicações, no processo de desenvolvimento da alteridade, e no reconhecimento de processos intrapsíquicos frente aos atravessamentos do luto do outro no próprio trabalho de luto. Durante o grupo de apoio a um casal, uma mulher disse: "Eu 
só sabia que, quando ele passasse pela porta e me visse, quieta, de pijama, ainda sem tomado banho e descuidada na aparência, ele ficaria furioso por eu estar chafurdando na minha dor" (Savage, 1989, pp. 99-100). Contudo o marido refletiu em terapia que, na maioria do tempo, se sentia mais desamparado que furioso, mas quando a esposa transparecia desamparada, ele entrava num modo defensivo. O processo terapêutico pode assim aprofundar a compreensão do processo inter e intrapsíquico do casal frente a dor da perda do filho, manifestando abertamente seus sentimentos, o que pode evitar condições patológicas que ocorrem na transferência de sentimentos para outros e o meio.

Ao tratar dos sonhos, Savage assinala que:

Os sonhos acentuam a resolução natural do luto ao tentar tornar consciente a influência real e a simbólica que a pessoa falecida exercia sobre a vida do sobrevivente. A real influência inclui, por exemplo, os papéis e as funções que a pessoa falecida teria ocupado, o companheirismo que essa pessoa podia ter oferecido e os modos pelos quais aquela vida teria enriquecido a vida do sobrevivente, a influência simbólica deriva mais do sentido que vinculamos ao relacionamento, como quando ao desempenhar o papel de pai de uma criança saudável, eu me torno uma pessoa que educa, dá amparo. Os sonhos são os meios de se apreender o sentido simbólico menos evidente do relacionamento, que precisa ser percebido para que o luto se torne completo ... Por mais estranho que isso possa parecer, a continuidade do relacionamento entre a pessoa falecida e o sobrevivente é preservada pelo sonho. Essa continuidade ajuda a pessoa que sofreu a perda a aceitar a finalidade dessa perda, a entender sua natureza unicamente pessoal e a compreender seu sentido. A compreensão se perfaz dentro de um processo de reintegração que se desenvolve gradualmente . . . Nos casos relacionados ao aborto "as imagens do sonho da criança ajudam a dar realidade à criança, e isso, então, possibilita ao pai reconhecer conscientemente a perda e pranteá-la abertamente. (Savage, 1989, p. 108)

Byington (2005), em seu trabalho envolvendo pacientes em luto patológico, afirma que o luto patológico está relacionado à dificuldade de elaborar a morte em seu aspecto simbólico. Tais casos são considerados pelo autor como neuroses que podem evoluir para espectros mais graves com o desencadeamento de quadros depressivos profundos até cisões psicóticas inclinadas ao suicídio.

Para elaborar essa fixação, a regressão deve ser propiciada dentro de um ritual psicoterápico para transgredir a fronteira de interdição por meio da imaginação em duas dimensões importantes. Uma pertence à interdição defensiva, da sombra, e a outra diz respeito à interdição da ciência materialista diante da ciência simbólica. (Byington, 2005, p. 189)

Byington utiliza uma técnica expressiva denominada "imaginação ativa" para auxiliar na elaboração de símbolos fixados ou não nos casos de luto patológico, e alerta para a necessidade de ser bem treinado o terapeuta que a utiliza pelo grande poder de mobilização emocional, e para os perigos de psicotização. De acordo com o autor, a técnica não pode ser utilizada com qualquer paciente, devendo ser uma decisão criteriosa: “o seu emprego com os símbolos da morte e dentro da emoção do sofrimento mobiliza 
uma extraordinária carga arquetípica, que transcende a fronteira interditante da inércia na dimensão espaço-tempo e, dessa maneira, tem um alto poder transformador da personalidade" (Byington, 2005, p.191), sendo uma técnica passível de ser utilizada na clínica junguiana.

Catta-Preta (2012), em seu livro, exemplifica o trabalho com sonhos e o potente auxílio deste instrumento na elaboração do luto. O caso atendido por ela, foi da paciente Laura, encaminhada por um Instituto do Sono da cidade onde viviam, e tinha como queixa primária uma insônia crônica. Já na primeira sessão, a paciente relata à terapeuta a morte de seu filho jovem (João), que perdera sete anos atrás. O sofrimento ainda era agudo e latente. A paciente não conseguira até então reorganizar-se dentro dessa tragédia, mas manipulava a interação social para que as pessoas não a perturbassem por causa do seu sofrimento, já que a morte e o sofrimento são aspectos difíceis para a sociedade que considera estes temas um tabu.

À noite a paciente não conseguia dormir, mesmo fortemente medicada. CattaPreta utilizou os sonhos que ela trazia a partir da técnica de interpretações de sonhos criada por Jung. A psicoterapia pode auxiliar Laura a ressignificar a morte de seu filho, e elaborar, enfim, o luto desta perda: "seus sonhos mostraram o quanto sua dor era presente e, a partir da análise deles, podemos acompanhar a elaboração do luto de Laura, bem como podemos entender o significado simbólico da insônia em sua vida. Laura, conscientemente, queria dormir, mas inconscientemente precisava se manter alerta, vigilante. Desisntalar esse comportamento foi um longo processo, mas como resultados definitivos e não transitórios" (Catta-Preta, 2012, p.110).

Catta-Preta compilou 30 sonhos da paciente que tinham relação com a morte de seu filho, e apresentou a análise um a um. A seguir trago um dos sonhos para ilustrar o movimento de elaboração do luto:

Sonho 3- março de 2004 "sonhei que eu fazia partos e as crianças eram muito pequenas. Num deles me empenhei mais e João virou-se para mim e carinhosamente chamou-me: 'Mãe'. Fiquei surpresa. Ele olhou para a criança e disse: 'Luz e paz'. (CattaPreta, 2012, p. 112)

Mais adiante,

No terceiro sonho, ela passa a dar a vida a crianças, em uma função de parteira. $\mathrm{O}$ sonho mostra sua capacidade de trazer conteúdos para a consciência. João aparece novamente abençoando e dando mensagens positivas para que ela possa prosseguir. Esse sonho parece exercer a função compensatória, proposta por Jung, com o objetivo de autorregulação da psique, ou seja, para que Laura saia do oposto em que se encontra, de sofrimento e dor, dando à luz aspectos criativos novos que precisam vir para sua consciência. (Catta-Preta, 2012, p.126) 
Ao final do processo, a paciente se sentia melhor, ressignificando profundamente seu processo de luto. De acordo com a autora, Laura conseguia dormir (sem medicação) e acordar em paz, sem despertar com sentimentos perturbadores de angústia e agonia, como apresentava no início do processo. O tratamento durou quatro anos, em cada sessão, a paciente trazia um sonho para ser trabalhado "foi um processo longo e no qual trabalhamos questões que envolviam suas relações com o mundo, sua passagem pela metanoia e todas as transformações que ocorreram em sua vida." (Catta-Preta, 2012, p.111)

\subsubsection{Processo terapêutico em grupo}

Existem trabalhos bem consolidados entre pós-junguianos a despeito do uso da modalidade grupo, contudo não há consenso ou sistematização sobre o método, o que, por um lado, permite uma flexibilidade do uso frente à diferentes demandas, mas, por outro, torna a psicoterapia em grupo um processo pouco utilizado pelos junguianos devido à própria desconfiança de Jung, à falta de sistematização e pesquisas sobre o método. O objetivo deste item não é a formação do terapeuta para que atue na modalidade grupal, já que, para adentrar nessa especialidade, é preciso formação específica e/ou estudos permanentes, supervisões, seguindo o mesmo rigor do trabalho enquanto psicoterapeuta na clínica individual.

Jung trabalhou essencialmente com terapia individual, por entender que o trabalho em grupo poderia ser nocivo ao processo de individuação. Para Jung (Jung, 2007), o risco está em não haver atenção ao processo de individuação nas situações em que o grupo é o setting. O terapeuta necessitaria estar atento ao fenômeno que o autor identificou como rebaixamento da consciência individual e do seu ponto mais grave, o auto esquecimento, no qual imitação e dependência são fatores que impedem em grande ou pequena intensidade o processo de confronto interno, de individuação.

Mas vale lembrar que o próprio Jung (2007) considerava que a personalidade não é apenas individual, mas também carrega sua característica coletiva. O ser humano é individual e coletivo ao mesmo tempo, o que se apresenta como um grande paradoxo para o autor: somos individuais e coletivos, únicos e semelhantes ao mesmo tempo. De acordo com o precursor da Psicologia Analítica, tanto os indivíduos quanto o próprio grupo recebem a influência do contexto em que estão imersos, ou seja, tanto indivíduo quanto os outros membros de um grupo desempenham papéis esperados socialmente e são 
carregados de uma bagagem influenciada pelo ambiente familiar, político, cultural, social e religioso que são provenientes. Diante dessas influências, são apresentadas uma ou outra persona, e essas irão se relacionar entre si no grupo (Jung, 2007). Esta relação pode se manter a serviço de relações estereotipadas, não trazendo à tona conteúdos e processos profundos num primeiro momento, mas, se o terapeuta puder ler esses sintomas em grupo, questões individuais poderão emergir.

Jung saiu em defesa da psicoterapia individual, pois vivera os contextos de guerras. Ele considerava um perigo as movimentações de massa. Como dito anteriormente, Jung afirma que tanto os indivíduos quanto o próprio grupo recebem a influência do contexto em que estão imersos, ou seja, cada participante desempenha papéis esperados socialmente, pelo menos num primeiro momento e são carregados de uma bagagem influenciada pelo ambiente familiar, político, cultural, social e religioso do qual são provenientes. Diante destas influências, são apresentadas uma ou outra persona, que irá se relacionar com o grupo. Até então, naquela época, não se ouvia falar de atendimento em grupo, nem se quer de atendimento de famílias. Estas modalidades foram estruturadas e consolidadas após esse período, e apresentando resultados positivos e consistentes. Nesse sentido, hoje a psicoterapia familiar e em grupo é uma prática consolidada.

O tratamento em grupo na Psicologia Analítica ainda carece de mais estudos e sistematizações, mas é um setting passível e útil para ser utilizado. Zinkin afirma que a questão do cenário é uma variável importante, mas ainda é recente o olhar sobre sua importância, indicando que foi só a partir dos estudos de Winnicott que foi iniciado este olhar mais esmerado sobre o espaço de contenção dos processos psíquicos.

Na psicanálise, a importância do cenário para análise só recentemente foi dada atenção, em grande parte por instigação de Winnicott (Winnicott 1965). Creio que nossas noções sobre o que constitui o cenário precisam de um refinamento considerável, e os grupos que fornecem um cenário (um setting) dramaticamente diferente enquanto mantêm o modelo analítico fornecem uma boa oportunidade para explorar essa questão. Os grupos podem ser altamente criativos, e o grupo analítico é configurado para ajudá-lo a ser assim. A criatividade está em muitos níveis diferentes. Para simplificar minha tarefa, vou limitar minha atenção a apenas uma área, a criação da própria configuração. $\mathrm{Na}$ análise individual ou chamada individual, isso costuma ser visto como uma área um tanto periférica, ou uma questão técnica, algo que precisa ser pensado na "criação" da situação analítica ou na manutenção de certos limites quando ameaçados, como pelo paciente agindo. É considerado simplesmente uma estrutura na qual todos os processos criativos ocorrem. Supõe-se ainda que é apenas o analista quem fornece a configuração, como um bom anfitrião faz para seus convidados. Essa visão tem apenas uma validade limitada. É um modelo que dificulta que o paciente faça alterações no cenário ou que o analista reconheça seu direito de fazê-lo. O paciente pode sentir-se obrigado a se adaptar ao que foi fornecido. (Zinkin, 1998, p.160, tradução minha) 
Testa e Serbena (2019) realizaram uma revisão bibliográfica ${ }^{19}$, sistematizando vários trabalhos importantes acerca da terapia em grupo sob a perspectiva da Psicologia Analítica. Algumas reflexões importantes serão tratadas aqui para auxiliar na reflexão da proposta do grupo enquanto setting terapêutico. Em primeiro lugar, os autores apontam que, de acordo com os trabalhos levantados, é claramente possível a utilização do grupo para o desenvolvimento do processo de individuação. Tendo em mente que a individuação é um processo que representa a atualização do self mais próxima possível, este fim ideal, é inalcançável em sua totalidade e não será alcançada devido a uma modalidade específica de tratamento. Nesse sentido, a psicoterapia individual ou grupal serve apenas como ferramenta para auxiliar no desenvolvimento psíquico, não se tratando de uma receita milagrosa para alcançar o si mesmo. O próprio Jung, de acordo com os autores, defende que individuar-se é destacar-se do comum, emancipar-se das regras gerais, das massas bancando a vida num caminho próprio. Realocando o ponto de vista original, temos que tal separação do coletivo não necessariamente é literal, mas psíquica, ou seja, separar-se do comum, do que é coletivo significa passar a obedecer às próprias leis, convicções, métodos e deles não fugir. Individuação e coletividade são caminhos díspares, mas não necessariamente estar no coletivo é o mesmo que estar sendo subjugado pela massa ou ser influenciado por um grupo.

Quando se fala em humanos, fala-se também em grupos humanos nos quais os indivíduos se desenvolvem e são a base da constituição do psiquismo. Nos grupos, a interação promove aprendizados, em uma relação de dependência em qualquer fase da vida. De acordo com os autores pesquisados, a vida social acontece antes, na mesma medida que a vida amalgamada no inconsciente acontece antes do nascer do ego ainda na infância. A partir desta experiência que o individual pode se diferenciar, tornar-se original. Ou seja, a partir da relação com o nosso grupo social, predicados são atribuídos a nós, contribuindo com a formação da persona que auxilia no trânsito das relações com o mundo externo. A persona é, portanto, um papel, um fecho da psique coletiva que tem a função de auxiliar nessas relações entre o ser humano e a sociedade. Relacionar-se é algo necessário para o processo de individuação. Interagir com os componentes fora do ego é imprescindível para a existência e para o autoconhecimento, já que o diálogo interno

\footnotetext{
${ }^{19}$ Este artigo de revisão apresenta, a partir de uma revisão estruturada em base de dados de artigos em português e inglês e outras literaturas frequentemente citados para apresentar um panorama das pesquisas que tratam da influência no processo de individuação (desenvolvimento da personalidade) de indivíduos que participam de pequenos grupos psicoterapêuticos dentro do referencial da Psicologia Analítica.
} 
é dependente do diálogo com o mundo externo, lembrando que somos seres sociais, coletivos e culturais. Nesse sentido, ao ouvir as vozes externas, consigo compreender também as vozes internas.

Um segundo ponto frequente nos artigos encontrados é o reconhecimento dos aspectos feminino, maternal, regressivo e transformador nos pequenos grupos. De acordo com Testa e Serbena (2019), os grupos sociais funcionam como uma matriz para o desenvolvimento do indivíduo. Contudo, se o indivíduo permanece identificado a ele, o sujeito tende a ficar inconsciente, com sua individualidade ameaçada por existir uma falta de consciência entre os membros. No entanto, de maneira positiva, o grupo social provê a sensação de segurança e proteção aos que se sintam identificados a ele. Essa dinâmica de estar contido no grupo pode ser por analogia igual à contenção do ego pelo inconsciente.

O setting grupal pode então acolher, induzindo o sujeito a um estado de regressão infantilizado de comportamento, sendo danoso nos casos em que houver fixação, estagnação do processo de individuação. Contudo, vale lembrar que isso também seria um problema se ocorresse esta mesma fixação da regressão no setting da psicoterapia individual. No entanto, é importante relembrar que, de acordo com Jung, a progressão e regressão da libido fazem parte do desenvolvimento psicológico e geralmente ocorre em momentos de extrema dificuldade em lidar com uma situação, com um certo conteúdo e/ou com uma nova adaptação. Metaforicamente, a energia escoa da consciência para o inconsciente. No nível psicológico, a volta a um estado mais infantil (ou até embrionário dependendo do grau de regressão) remete ao retorno ao inconsciente, um modo de ativar recursos inconscientes para lidar com as dificuldades vivenciadas. Sendo assim, a regressão torna-se um poderoso movimento para que uma nova adaptação ocorra com a ajuda dos novos conteúdos acessados. Como dito nos capítulos anteriores, este processo não é uma degradação, mas uma fase do desenvolvimento que auxilia ao ego, a partir dessa dissolução parcial de um modo de ser polarizado, na busca de uma integração fértil e potente com aspectos ainda não conhecidos pelo centro da consciência.

Quando o fenômeno da dissolução parcial do ego através da regressão ocorre num grupo, isto significa que o self está sendo experimentado como uma projeção e ele - projetado ou não - seria o agente desta dissolução. Tal fenômeno provoca "a coletivização de indivíduo, cujas características ímpares são dissolvidas por uma identificação com o novo ponto de vista". Porém, a dissolução em seu aspecto superior seria a possibilidade da redução do ego como um prelúdio ao posterior surgimento de uma personalidade mais ampla, vinculada ao self. 
Então, desde que os membros não se fixem nos aspectos regressivos de grupo, esta dissolução de aspectos egóicos não vinculados ao self seria uma das condições fundamentais para a ocorrência da individuação. (Testa \& Serbena, 2019, p. 12)

Zinkin (1998) afirma que o aspecto feminino do grupo está relacionado à função de continente. Nele, conteúdo e continente (contenção, suporte e nutrição) se transformam dinâmica e reciprocamente, análogo ao que ocorre em um vaso alquímico que opera interagindo consciente e inconsciente. A partir dessa relação, o ego pode ser renovado, transformado, mas pode ser ameaçado em sua individualidade, dissolvendo-se total ou parcialmente. Os autores apontam, porém, que os membros do grupo terapêutico, podem aprender a se defenderem da ameaça da dissolução pela identificação regressiva.

Fazendo referência ao trabalho de Whitmont (1964) e Freitas (2005), Testa e Serbena apontam que:

. . . no setting terapêutico cada participante tem a oportunidade de se afirmar e de ser confirmado pelos outros integrantes e, deste modo, o grupo favorece o desenvolvimento, o grupo favorece o desenvolvimento da alteridade protegendo seus membros da dissolução da consciência e criando uma imunidade ao contágio psíquico das massas. (Testa \& Serbena, 2019, p. 12)

Agora passo a tratar da última reflexão pertinente a este ponto da presente pesquisa, que é relacionada aos pressupostos teóricos que mais se aproximam de uma análise junguiana de grupo. A primeira característica é que, assim como na psicoterapia individual, o psicólogo adota uma perspectiva simbólica e que, "a teoria do self, como continente e regulador de todas as partes distintas da personalidade, é aplicável também à psicologia dos grupos" (Testa \& Serbena, 2019, p. 70). Nestes trabalhos existe um desejo de explicar como é utilizado o modelo arquetípico e simbólico. Nesta modalidade as imagens e conteúdos aparecem espontaneamente, produzidos pelos próprios membros, sendo construtivos quando bem confrontados pelos membros do grupo. Inclusive apontam que determinadas dimensões do arquétipo só poderiam ser experimentadas em grupo. De acordo com Whitmont (1964)

... temas arquetípicos se manifestam através dos conteúdos produzidos pelos membros, assim como em seus padrões de relacionamento, e que o surgimento de imagens observáveis nos grupos fornece material para análise, assim como sinalizam as fases de transformação quais tanto o grupo quanto seus membros passam, já que essas imagens arquetípicas ilustram também a relação entre consciente e inconsciente. (Whitmont, 1964 citado por Testa \& Serbena, 2019, p.13)

Existe uma preocupação com essa dinâmica no caso de os indivíduos não conseguirem amortecer no consciente os conteúdos constelados a partir da atuação dos arquétipos, principalmente em grupos massificados. De acordo com Jung (2013m), este perigo é real. Contudo, existe a parcela ou a outra face da moeda que mostra que os 
conteúdos trazidos também podem ter um grande valor, como uma promessa de renascimento.

Outro ponto é com relação a compreensão de que existem níveis e sistemas de interação nos processos grupais: o primeiro nível está relacionado ao sistema intrapsíquico; o segundo, ao sistema interpsíquico, transacional no qual os membros interagem entre si; o terceiro teria relação com um self grupal.

Byington (38) ampliou o conceito de self para abranger qualquer dimensão de totalidade além da personalidade individual. O self grupal seria um sistema que em função da representação e da interação psicodinâmica de seus componentes seria capaz de estruturar a identidade do ego e do outro, tanto na consciência quanto no inconsciente. (Testa \& Serbena, 2019, p. 13)

Zinkin (1998) afirma que o grupo é onde o espelhamento aparece. Para este autor, o relacionamento é primário, e o individual é uma realidade secundária. Whitmont (1974) afirma que trabalhar os aspectos inconscientes no setting grupal tem o mesmo grau de importância que trabalhá-los em sonhos ou em imaginação ativa. O contato com o outro permite um contato rico com outros tipos psicológicos, outros modos de reflexão sobre a vida, o que auxilia na compreensão mais aprofundada dos processos psíquicos, seja reafirmando, provocando embates e ampliando o trabalho interno e as projeções.

O acesso aos conteúdos psicológicos e a possibilidade de verbalização desses conteúdos é fundamental em um grupo vivencial. De acordo com Freitas (1990), a palavra é uma via importante para a elaboração dos símbolos, é a partir da fala que se integra os conteúdos inconscientes com a consciência, e falar no contexto grupal pode ser um exercício mais fértil.

Segundo Freitas (2005), o processo de individuar-se não tem a ver com o isolamento, e com proteger a individualidade de um contato com a coletividade. É possível dizer que a relação com o coletivo permite que o processo de individuação seja alimentado por contribuições advindas das relações com o grupo, e que o desenvolvimento e ampliação dos aspectos individuais depende do diálogo ego-self. Nesse sentido, o trabalho em grupo, quando cuidadosamente coordenado, pode ser uma fonte interessante de crescimento individual e grupal. A autora aponta que, por meio do contato com o outro, com outras histórias, com outras experiências é possível que os aspectos internos sofram ressonâncias, por afinidade ou oposição a elas.

Ampliando o espectro do cuidado em grupo, temos o grupo familiar, que também é hoje uma modalidade de tratamento psicoterapêutico. Boechat (2011) afirma que o indivíduo, mesmo sendo único, deve ser compreendido também a partir do lugar ocupado 
no sistema familiar e utiliza o termo "individuação relacionada" em seu trabalho com famílias. A autora junguiana afirma que o nível de saúde nas relações familiares está diretamente associado a uma boa individuação relacionada.

A autora afirma, que o sintoma (físico e psíquico, por exemplo) que aparece no sistema tem função homeostática para a psique individual, e que se configura como um símbolo que indica tanto a jornada para a individuação quanto para a cura. $\mathrm{O}$ trabalho com grupo de pessoas "desconhecidas" (a princípio) e com membros familiares tem sido tratado atualmente nas pesquisas e no desenvolvimento de instrumentais técnicos. $\mathrm{Na}$ sequência, apresentarei alguns autores junguianos e suas respectivas experiências com grupo. Alguns o utilizam como uma modalidade suplementar, não processual, com o objetivo de trabalhar aspectos pontuais, pois, nesses casos, os terapeutas entendem que não seria interessante substituir a psicoterapia individual. No entanto, outros autores consideram benéfica a utilização combinada/paralela tanto da análise grupal quanto da individual, pois a riqueza de ambos os recursos pode auxiliar no avanço do processo de crescimento e, portanto, na individuação, contudo também existem os psicólogos que utilizam a modalidade de modo processual, entendendo que a psicoterapia em grupo pode ser uma via utilizada positivamente como caminho terapêutico para o desenvolvimento e individuação.

Aqui apresentarei os pontos de vista de dois extremos: de um lado, autores que trabalham com o grupo como processo psicoterapêutico contínuo; do outro lado, autores que utilizam o grupo como intervenção pontual, vivencial (Freitas, 2005, Parisi, 2009; Whitmont, 1964, Ettin , 1995; Zinkin, 1998). Na literatura encontrada foi averiguada constante atenção do/da psicólogo/psicóloga aos aspectos simbólicos trazidos/criados pelo grupo, o uso da transferência, da interação no grupo, foco dos profissionais na individuação e o uso de materiais expressivos e mitos.

Freitas (2005) pontua que talvez seja o psicólogo Louis Zinkin o autor junguiano que mais se dedicou a pensar o trabalho terapêutico em grupo. Para ele, não havia essencialmente diferença entre o processo individual e em grupo, sendo que ambos são capazes de produzir o tipo de mudança imprescindível para o desenvolvimento humano: a individuação. Zinkin (1998) afirma que análise de grupo é construtiva e que alguns pontos são imprescindíveis para ter um grupo produtivo, como tamanho do grupo, seleção de seus membros, o papel do condutor e a criação de um setting adequado (sustentação ambiental aos moldes do holding materno). 
Grosso modo, este autor utiliza amplamente a análise da transferência no aqui e agora durante os atendimentos em grupo. Contudo não dá ênfase aos sonhos, ou aos mitos como os junguianos fazem frequentemente. A ideia de um funcionamento grupal, para o autor, perpassa pela compreensão de que os grupos têm sentimentos, fantasias que não nascem propriamente de um indivíduo, mas do compartilhamento de processos.

Frequentemente, isso quer dizer que o coletivo do grupo constrói um tipo de imagem ou uma produção comum (we-production), ao invés de uma produção individual. Não apenas todo terapeuta de grupo considera essa formulação indispensável, como também eles enxergam a capacidade do grupo de elaborar e trabalhar com estas imagens divididas e compartilhadas como um sinal de que está se desenvolvendo de maneira criativa e que isso é uma terapia em grupo. Portanto, está se tornando cada vez mais um ambiente terapêutico para seus membros. Na tradição da terapia individual o terapeuta está frequentemente contente em observar as fantasias como pertencentes ao indivíduo cuja sua única individualidade é respeitada e fomentada. (Zinkin, 1998, p. 152, tradução minha)

Para Whitmont (1964), esta modalidade terapêutica é específica e pode ser bastante valorosa. Não como um atalho acelerando os processos que seriam alcançados em terapia individual, e não seria também uma forma de terapia de massa. Neste tipo de modalidade, podem ser experienciados relacionamentos e elaborações de transferências pelo fato de que o processo está sendo conduzido e analisado cuidadosamente. Aqui seria acessada uma condição diferenciada, que não se encontra na terapia individual, o que o autor apontou como o acesso a uma qualidade arquetípica peculiar, como dito anteriormente. $\mathrm{O}$ grupo pode funcionar como um continente, protegendo e amparando conteúdos psíquicos, bem como os afetos de seus membros, incluindo conteúdos conflituosos, e sombrios. O grupo teria a função de receptáculo, uma imagem arquetípica que impinge a noção de fronteira, continente que impede o conteúdo de se esvair como fluido que escapa, mas, por outro lado, protege seus conteúdos das hostilidades externas. De acordo com o autor, os grupos possibilitam a vivência mais autêntica, podendo haver o abandono de personas, ou seja, o indivíduo pode se sentir em um ambiente seguro, protegido, ser o que realmente se é.

Como dito anteriormente, o processo de individuação também pode acontecer dentro da terapia grupal. Segundo Freitas (2005, p. 51), “embora a individuação implique a ampliação e constante estruturação dinâmica da consciência, o indivíduo não é sinônimo de ou equivalente à consciência, e tampouco coletividade corresponde a inconsciente". Vale relembrar que, no processo de individuação, o sujeito precisa realizar movimentos que saiam do script coletivo para compreender melhor as necessidades próprias, originais. Porém, é necessário, num outro momento, voltar para o coletivo mais consciente de si, 
diferenciado em seu processo. Dessa forma, é preciso ponderar que a Psicologia Analítica aponta para o coletivo no individual, e considera produtivo fazer o caminho contrário, tratando o indivíduo no coletivo com o objetivo de se conhecer mais.

Para Silveira (2018), mesmo ocorrendo em grupo, o enfoque do trabalho será a individuação de cada participante. De acordo com Zinkin (1998), Jung considerava o inconsciente primário e o consciente secundário e, para individuar o ego, precisaria ser forte o bastante para suportar as pressões coletivas. No campo terapêutico, nesse sentido o psicólogo que trabalha em grupo deverá considerar com cuidado os pacientes que poderiam ser atendidos em grupo ou não. A coletividade, longe de ser um perigo, pode ser fonte de criação, ajudando o sujeito a identificar o que lhe é ou não próprio, individual. O valor terapêutico do grupo é imenso. Zinkin (1998), em crítica a Jung, afirma que não é possível ignorar o nosso "patrimônio coletivo" (p. 154), e que a consciência é também nutrida pelo inconsciente coletivo. $\mathrm{O}$ mar do inconsciente também é uma grande mãe, contendo seus aspectos nutritivo e destrutivo.

A tarefa da individuação não é simplesmente afirmar a individualidade em face da multidão que deseja destruí-la. É igualmente importante reconhecer que nenhum homem pode viver em isolamento, que nossas vidas não têm sentido em si mesmas. O significado é derivado do coletivo, do qual cada um de nós faz parte. Assim, devemos continuamente renascer ou ser transformados voltando para a mãe, por assim dizer, para sermos engolidos pelo dragão e sairmos novamente renovados. Esse é o grande tema arquetípico que Jung expressou eloquentemente no primeiro trabalho que levou à sua separação de Freud, A Psicologia do Inconsciente (mais tarde revisado e republicado como Símbolos da Transformação (Jung 1912). (Zinkin, 1998, pg.155, tradução minha)

Ettin (1995) afirma que a prática analítica em grupo está afinada à prática psicoterapêutica individual. A perspectiva junguiana é atenta às ambivalências da natureza humana, como a interação entre inconsciente e consciente, sombra e persona, dinâmica pessoal e cultural etc. A equilibração da psique está relacionada ao movimento de reconhecimento e integração dos aspectos que durante a vida foram subvalorizados, projetados, ou apartados da noção do eu. Ampliando tal compreensão, individuar-se está relacionado a lidar com as contradições inerentes a fim de reintegrar os aspectos apartados. Nesse sentido, Ettin (1995) afirma que um espaço fértil seria o grupo terapêutico bem equilibrado e bem coordenado (com mediação apropriada), pois este possibilita a percepção das múltiplas inclinações pessoais e permite reflexões sobre os conflitos e polarizações.

Explorar o inconsciente, em sua manifestação numa experiência grupal, é tão importante quanto experienciá-lo pela introversão através de sonhos ou imaginação ativa, e aponta as vantagens do que denomina "análise num setting grupal": o indivíduo sente que pertence a algo maior, pode experienciar tanto conformidade quanto singularidade, buscar 
autossustentação, conviver com uma ampla gama de tipologias e pontos de vista, vivenciar situações numa concretude maior e, além disso, amplia-se o trabalho com as projeções e as possibilidades de um relacionamento genuíno. Whitmont destaca que o arquétipo do grupo pode ser vivenciado tanto na dimensão que envolve sentir-se pertencendo, quanto na que implica valores e leis. (Freitas, 2005, p.51)

Símbolos podem ser manifestados e produzidos por meio da interação grupal. Nas palavras de Ettin: "Se um grupo é verdadeiramente autorreflexivo, ele se reconhecerá nos conteúdos significativos que surgem para elucidar processos significativos. Ao fazer isso, os participantes descobrem o que é comum e incomum em sua experiência de si e do outro.” (Ettin, 1995, p. 450, tradução minha).

Além do uso processual da psicoterapia de grupo, como visto até então, existe um outro formato, denominado "grupos vivenciais". Para Freitas (2005), este formato permite serem trabalhadas questões de modo pontual, e pode ser desenvolvido em alguns encontros (e não em apenas uma intervenção). Neste trabalho, a autora teve como objetivo explorar o potencial criativo da persona. Para tanto Freitas utiliza técnicas para trabalhar a persona dos indivíduos do grupo, como a construção individual e artesanal de máscaras e personagens, utilizando para isso recursos expressivos: corporais, plásticos e, também, dramáticos. Ao final, a vivência é elaborada verbalmente, momento dedicado à compreensão dos aspectos simbólicos que emergiram da experiência individual. Todos os passos são experimentados e trabalhados em grupo, o que não tira de foco a manifestação/experiência individual que, em seu caso, recebe uma atenção especial. Para Freitas, os grupos vivenciais favorecem a alteridade, visto que, em tal dinâmica, o participante tem a oportunidade de se afirmar e ser confirmado, num ambiente interacional fértil. Parisi (2009) reforça:

Em minha prática com grupos vivenciais utilizo diversos recursos de forma alternada visando oferecer um leque amplo de possibilidades de acesso e expressão de conteúdos inconscientes para favorecer o processo de elaboração simbólica. Muitas vezes mitos ou contos eram narrados e posteriormente eram oferecidos materiais plásticos para a expressão dos aspectos mobilizados individualmente que depois eram partilhados e elaborados conjuntamente no grupo. Algumas vezes era proposta uma imaginação dirigida como uma forma de trazer para a experiência pessoal a temática apresentada na história relatada. Utilizando estes recursos, o material do mito adquiria uma conotação e um significado individual, favorecendo a elaboração simbólica e a ampliação da consciência. Em outros grupos, o ponto de partida não foi um mito ou conto, mas um tema desenvolvido e vivenciado através de recursos expressivos. Desta forma todo aquele encontro do grupo ocorria em torno de um tema central. (Parisi, 2009, p.62)

Independente se é grupo processual ou grupo vivencial, é imprescindível que haja cautela e cuidado na condução do trabalho. É importante que o psicoterapeuta tenha claro o objetivo do trabalho e esteja bem ancorado teoricamente. Zinkin (1998), seguindo a escola de Foulkers, por exemplo, trabalha com a análise do grupo pelo grupo, incluindo 
o condutor como elemento integrante do processo de grupo, avaliando também transferência e contratransferência como sendo uma noção de grupo como um todo. Neste modelo, indivíduos e subgrupos têm o grupo como ambiente de sustentação. $\mathrm{O}$ trabalho de Zinkin (1998) inclui as contribuições de Winnicott sobre a importância do setting terapêutico que precisa funcionar como um espaço psicológico aos moldes do holding materno.

Outra contribuição de Winnicott na construção da prática da psicoterapia em grupo é a compreensão do papel do brincar. Para o autor, o brincar é algo natural e de primeira importância para acontecer entre analista e paciente (Winnicott, 1968i). O brincar conduz naturalmente à experiência de criar e encontrar a si e ao mundo. Dessa forma, o brincar deve ser uma terceira via que deve estar presente na relação terapêutica:

Para Winnicott, o lugar em que vivemos (quer dizer, o lugar em que vivemos a partir da ação criativa do verdadeiro self) não é nem o mundo interno, nem o mundo externo, ele é criando e encontrado, tal como são os objetos transicionais, de modo que, num mesmo gesto, num mesmo tipo de ação, o indivíduo encontra a si mesmo (busca do self) e cria o mundo no qual se encontra. A experiência cultural, o encontro do homem com o homem, na tradição cultural e na comunicação individual, corresponde a um tipo de produção humana que não é redutível nem ao mundo interno nem ao mundo externo, ele é um entre: "O lugar em que a experiência cultural se localiza está no espaço potencial [espaço onde podem existir os objetos e fenômenos transicionais] existente entre o indivíduo e o meio ambiente (originalmente, o objeto). O mesmo se pode dizer do brincar. A experiência criativa começa com o viver criativo, manifestado primeiramente na brincadeira. (Fulgencio, 2017, p.62)

Outro ponto importante é que, dentro da psicoterapia grupal, o facilitador deve estar atento aos movimentos individuais e grupais, e precisa acolher os envolvidos, principalmente aqueles que nunca participaram da dinâmica proposta, para que estes possam metaforicamente estar confortáveis, confiantes a ponto de descansar a armadura do lado de fora e abrir para a experiência oferecida, inclusive para brincar, ponto que será melhor tratado no próximo item.

Para tratar com mais clareza acerca do papel do psicoterapeuta, cabe aqui recorrer à mitologia, mais especificamente à representação da deusa Héstia como apontado por Freitas (2005). De acordo com a autora, a deusa Héstia traz em si representada um clima psicológico necessário para tornar o ambiente um lugar de encontro e acolhimento. Apesar de ser uma deusa com atributos pouco valorizados no contexto atual, ela concebe a possibilidade de criar um clima familiar, de encontro ao pé da lareira, de comida sendo feita ao redor do fogão à lenha, com a convivência multigeracioanal, e coabitação de opostos, possibilitando o repousar, a espontaneidade, a segurança para se nutrir e acessar 
histórias e sentidos. Sem este clima, o espaço-grupo torna-se frio e inóspito, ou fomentar um certo tipo de calor que pode queimar, violentar, invadir.

Coordenar um grupo vivencial implica encarregar-se do estabelecimento e manutenção de um campo interacional, no qual os símbolos possam se definir, apresentar, interagir e ser, em alguma medida, assimilados à consciência. Aspectos narcísicos da personalidade podem ter uma vivência dionisíaca, que lhes permita movimento, reconhecimento e interação. E aos aspectos ecoístas é dada a oportunidade de reflexão, experiência narcísica, e de consequente busca de expressão e comunicação mais eficazes. Sendo a articulação entre persona e sombra constante e dinâmica, abre-se a possibilidade de trabalhos vivenciais em contextos não estritamente terapêuticos, mas pedagógicos. O trabalho em grupo permite inúmeras possibilidades, dependendo do objetivo proposto e do que se constele no campo interacional. Há uma oportunidade, compartilhada, de ensaiar personas, de pôr em movimento a totalidade psíquica e, quem sabe, de criar novas personas em nível social, no mínimo, a de participante de grupos vivenciais, o que dá certo suporte à personalidade para que, em outros contextos, explore novos meios de reflexão e expressão de seus próprios símbolos e dos que se apresentem no âmbito coletivo, em cada situação. (Freitas, 2005, p.50)

Ainda tratando da postura do terapeuta e do olhar para os aspectos simbólicos trazidos e/ou criados pelo grupo, trago um caso apresentado por Ettin (1995). Este autor apresenta a experiência de Hopper $(1991,1994)$, terapeuta que trabalhou com um grupo sediado em Londres. Em sua descrição, o grupo percebeu durante algumas semanas a aparição de um ninho de vespas na sala de terapia, com zunidos, movimentações diferentes e, por fim, o extravasamento de uma substância marrom na parede. Sob a perspectiva de um analista junguiano, o holofote colocado pelo grupo sob o ninho não poderia ser deixado de lado porque contém a possibilidade de ser um símbolo para o grupo. Diante deste olhar, o terapeuta possibilitou que o grupo falasse mais sobre o ninho e deixou que o símbolo falasse por si mesmo, envolvendo os membros do grupo na elaboração dos conteúdos e afetos trazidos.

O terapeuta pode se perguntar em voz alta: Qual é o burburinho que vem acontecendo, aqui, por essas muitas semanas? O que os membros imaginam que está acontecendo dentro desse ninho? Qual substância pode estar vazando? Que perigo isso apresenta e para quem? Como essa saturação será atendida? O que vai acontecer se não lidar com o vazamento de uma corrente? Ao intervir dessa maneira, o terapeuta está tratando a forma simbólica como se fosse o grupo. Os membros não devem ser encorajados a usar sua imaginação criativa para elaborar e contextualizar a imagem e seu significado para eles como indivíduos e como um grupo. Eles fazem isso envolvendo-se em um ato de autorreflexão, quando relacionam o ninho da vespa, como símbolo, ao grupo do WASP (vespas). O ninho como objeto material e metáfora representa o próprio grupo, através de uma concordância da realidade externa e interna. (Ettin, 1995, pp.450-451, tradução minha)

O grupo, de acordo com Ettin (2005), tem a capacidade de gerar símbolos, mitos, cultura e estas podem levar a soluções integradoras para os indivíduos que o pertencem. A ideia de ninho, na leitura do autor, remete ao aspecto materno do grupo, que pode 
aquecer, nutrir e também aprisionar, sufocar. O convívio grupal acessa o arquétipo da Grande Mãe, em seus aspectos positivos e negativos. O símbolo do ninho de vespas do grupo citado foi então compreendido pelos autores envolvidos na análise como sendo um símbolo de um espaço fechado, que protegia contra o abandono, ameaça de aniquilação e ansiedade. O símbolo apresentado teria relação com o fato de que o terapeuta sairia de férias em breve e os participantes do grupo produziram simbolicamente uma representação que desse conta de extravasar a ansiedade de separação. Esta experiência trouxe a possibilidade de lidar com uma amplitude de questões internas, desde a ansiedade de separação, medos desoladores, a relação com a mãe pessoal e como a mãe coletiva, as projeções, aspectos sombrios etc. De acordo com Ettin, um material simbólico como esse pode ser tratado nas instâncias pessoais, grupais e a intenção arquetípica para a condição humana (de conteúdos transpessoais).

Freitas (2005) acrescenta que a riqueza da perspectiva simbólica dentro dos grupos está relacionada à tecelagem, muitas vezes não-convencional, do fio condutor da individuação, que interage com o grupo na dinâmica com o self relacional, e que remete a movimentação do próprio self:

Esse fio é o símbolo, que permite a dimensão vivencial, envolve a personalidade total, abrange sempre suas dimensões racionais e irracionais e não deixa escapar a tonalidade afetiva e emocional do que quer que esteja sendo vivido. E não menos importante é a consideração do self relacional, seja ele individual ou grupal, terapêutico ou pedagógico, pois tais vivências se dão sempre em campos interacionais, isto é, na rede de relações transferenciais e compartilhadas. (Freitas, 2005, p.65)

Esta etapa é fundamental pois não basta só representar, ou somente entender racionalmente as imagens. De acordo com a Psicologia Analítica, da confrontação dos opostos surge um terceiro elemento, que é a função transcendente (Parisi, 2009). Como dito anteriormente, não é uma valorização da função intelectual. Para alcançar o terceiro elemento, deve-se manter o caráter simbólico do objeto, compreendendo as imagens com o objetivo de integrar os aspectos simbólicos à consciência.

... [o] símbolo conserva elementos desconhecidos à consciência, ou seja, algo permanece inacessível e inapreensível . . . o símbolo conserva elementos desconhecidos à consciência, ou seja, algo permanece inacessível e inapreensível. Esta qualidade faz do símbolo um mediador entre consciente e inconsciente, entre o oculto e o revelado. Jung (1921/1976b) enfatiza que o símbolo só é "vivo" enquanto seu sentido ainda não for esclarecido, enquanto for a 'melhor expressão possível'. (Parisi, 2009, p. 60)

O uso da transferência na análise do grupo é uma dinâmica frequentemente tratada pelos autores. Ettin (1995) apresenta um exemplo de como um grupo operou para lidar com suas questões transpessoais. Neste processo o grupo "transfigurou" um dos participantes atribuindo características e força mítica. A inflação do determinado membro 
ajudou o grupo a lidar com ansiedades existenciais e circunstâncias tidas como catastróficas. $\mathrm{O}$ exemplo trazido pelo autor é relativo a um grupo no qual grande parte era composto por sobrevivente, ou parentes de vítima do holocausto. A interação grupal levou a histórias de perseguição e violência, levando o grupo a uma perda de força vital, criativa diante do contato com a grande dor pessoal e coletiva que marca este período. $\mathrm{Na}$ sequência, uma mulher idosa começou a falar sobre esperança, futuro e se abriu, descrevendo sobre um caso amoroso que estava vivenciando apaixonadamente. $\mathrm{O}$ grupo mergulhou em suas histórias, fascinado com sua alegria e vibração. Foram projetados nesta mulher um papel transpessoal que acessava desejo, sexualidade apaixonada, aspectos do arquétipo da Grande Mãe, que seduz e acalenta. Este movimento foi necessário para que o grupo pudesse sobreviver às memórias aniquiladoras e transcender seus conteúdos sombrios. Aos poucos, o grupo foi se equilibrando, as projeções esvaziadas, e a mulher voltou a ter "proporções humanas". Neste ponto, o trabalho foi olhar para este processo de inflação e deflação da projeção coletiva para o reconhecimento do que se estava tentando resolver na tela-mulher-transpessoal.

De acordo com Ettin (2005), as projeções no grupo têm o objetivo de evitar ferimentos no processo. Contudo, deve-se passar a reconhecer a dinâmica, causas e necessidades, ou seja, deve ser reconhecido pela consciência o serviço prestado daquela pessoa-tela, líder transitório que auxiliou em processos mais profundos. A função transcendente permite as conexões entre consciente e inconsciente, transpondo e desaguando em novas formas de ser. À medida que indivíduos e grupos penetram na ampliação dos símbolos, emergem aspectos do inconsciente. Esses são carregados muitas vezes de contradições, oposições irreconciliáveis com o eu e o grupo consciente. A transformação gera consciência e a potencial integração dos opostos.

A ressonância com o processo dos outros membros torna-se rica e profunda. Zinkin (1998), neste trabalho, apresenta a análise de Winnicott sobre o espelhamento mãe-bebê. Winnicott (1971 citado por Zinkin 1998) vê o espelhamento como algo benigno e integrador, se a sustentação for suficientemente boa. Esta integração leva ao desenvolvimento de um self saudável e, do contrário, a aniquilação do si mesmo.

Contudo, Zinkin (1998) apresenta uma reflexão acerca do espelhamento maligno nos grupos analíticos. O autor traz a ideia de que o espelhamento que ocorre nos grupos pode ser paradoxal, ora benéfico, ora perigoso, e que cabe ao analista operar as intervenções necessárias para melhor conduzir o trabalho. $\mathrm{O}$ espelhamento pode auxiliar no processo de autoconhecimento, tornando possível a ação de trazer para a consciência 
aspectos que muitas vezes estão na sombra, no inconsciente, aspectos dolorosos e difíceis de lidar (autoestranhamento). Apenas conhecendo a si mesmo é possível conhecer o outro, afirma o autor. Outro aspecto é com relação à postura do terapeuta que constantemente tenta mostrar como o paciente é, de modo objetivo, correto. Contudo, esta noção do outro pode ser completamente diversa, não significativa para o paciente. A terapia em grupo reduz a tendência de interpretação objetiva, já que a presença de muitos componentes introduz muitos pontos de vista. Zinkin (1998) afirma que:

Nós os encorajamos a reagir livremente e espontaneamente uns aos outros. Desencorajamos que eles sejam muito intelectuais nesse processo e façam as interpretações desvinculadas que esperamos de um psicanalista, e, como terapeutas, nos colocamos em segundo plano, principalmente empenhados em facilitar esse processo. Assim, cada membro pode usar os outros membros como espelhos, embora em geral ele não seja consciente disso. Como mencionei anteriormente, não é necessário invocar os mecanismos de projeção e introjeção. (Zinkin,1998, p.226, tradução minha)

Grosso modo, o espelhamento é fator terapêutico no processo grupal, que pode ser ou não encorajado pelo terapeuta. Este ocorre, segundo o autor, entre dois membros os quais passam a duelar destrutivamente. Enquanto isso, o restante do grupo fica paralisado, em uma atmosfera sem ar, não criativa. Frente a um espelhamento maligno (aniquilador), o condutor deve agir imediatamente. Veja que é preciso ter traquejo e consistência para não confundir tensão com espelhamento maligno. Esta intervenção poderá ocorrer utilizando várias técnicas, desde a verbalização, e também mitos, materiais expressivos, etc.

\subsection{A clínica da Psicanálise do ponto de vista de Winnicott}

Neste subitem, tratarei das contribuições de Winnicott para a compreensão acerca das fases do desenvolvimento e a sustentação ambiental. Como dito anteriormente, tais conceitos foram apontados como de suma importância, inclusive por junguianos que atuam e pesquisam psicoterapia em grupo (Zinkin, 1998). De acordo com Fulgencio (2017), as fases do desenvolvimento emocional são úteis e eficientes para o trabalho psicoterapêutico, pois correspondem a um novo critério de classificação e compreensão do processo de desenvolvimento humano na Psicanálise.

Passo agora a tratar dos modos de ser e estar no mundo de acordo com a teoria de Winnicott, apontando as reflexões sobre os tipos/níveis de integração e o holding necessário para cada tipo de paciente. Assim como Jung, Winnicott não trabalha com a formatação cartesiana do ser humano, no sentido de que a terapia teria por objetivo curar 
algo defeituoso ou errado. Nesse sentido, os dois autores acabam se aproximando por entenderem que o caminho para o desenvolvimento psíquico está relacionado ao processo de autoconhecimento, a busca do si mesmo, com as integrações necessárias e o cuidado ambiental, para Winnicott, e com o processo de individuação, para Jung. Mesmo sendo uma pesquisa interparadigmática, que mantém Jung e Winnicott em suas devidas linguagens, vejo que as contribuições de Winnicott poderão ser úteis aos psicoterapeutas junguianos que trabalham com grupos com os aspectos relacionados a questão da integração, ambiente, vínculo dentre outros.

Em sua clínica, Winnicott define o trabalho analítico como uma relação humana simplificada, na qual o terapeuta é quem cuida do paciente e, dessa forma, o analista deve se abster (assim como a mãe) de parte de suas necessidades/desejos para assisti-lo. O psicólogo pode assim realizar os cuidados ambientais, nem puxando nem empurrando o paciente, mas facilitando seu processo e dando a ele uma sustentação confiável. O objetivo é que o paciente vá integrando partes de si, e a partir dos cuidados recebidos possa enfim cuidar de si sem a figura do terapeuta.

No exemplo mais simples possível, uma pessoa que está sendo analisada consegue corrigir uma experiência passada, ou uma experiência imaginária, ao revivê-la em condições simplificadas nas quais a dor pode ser tolerada porque está sendo distribuída ao longo do período de tempo; tomada, por assim dizer, em pequenas doses, num meio ambiente emocional controlado. Como vocês bem podem imaginar, na prática concreta raramente existe algo tão descomplicado como isso, mas o contexto principal pode legitimamente ser descrito desta maneira. (Winnicott 1945h, p.36)

O ponto central, para Winnicott, é o processo de integração. Tal movimento é realizado na saúde. O indivíduo consegue progredir em seu desenvolvimento, pois pode ser sustentado suficientemente bem pelo meio ambiente. A progressão ocorre no desenvolvimento considerado saudável. De acordo com Winnicott (1945h), existe um tipo de adequação entre idade cronológica, e o modo de funcionamento afetivo do indivíduo. A compreensão da saúde e da doença para o autor está relacionada à possibilidade e à riqueza dos modos de ser e estar no mundo, sendo que, na saúde, o indivíduo poderá agir a partir de si mesmo ao integrar-se, adaptando-se ao mundo sem perder a espontaneidade. Acontece que, para Winnicott, o desenvolvimento na saúde está relacionado ao viver criativo, espontâneo e, também, com o desenvolvimento da capacidade de reparar danos, e de o indivíduo sentir-se ora deprimido, culpado e ora alegre quando as coisas estão bem. O desenvolvimento na saúde tem relação com a capacidade do indivíduo de cuidar de si mesmo e de se sentir responsável por uma vida que valha a pena ser vivida. 
A vida de um indivíduo não se caracteriza mais por medos, sentimentos conflitantes, dúvidas, frustrações do que por seus aspectos positivos. O essencial é que o homem ou a mulher se sintam vivendo sua própria vida, responsabilizando-se por suas ações ou inações, sentindo-se capazes de atribuírem a si o mérito de um sucesso ou a responsabilidade de um fracasso. Pode-se dizer, em suma, que o indivíduo saiu da dependência para entrar na independência ou autonomia. (Winnicott, 1971f, p.30)

Contudo, se o próprio ambiente falha, o processo de progressão da integração é interrompido e criam-se defesas mais ou menos rígidas. A psique toma o caminho reverso, denominado regressão. As regressões podem ser transitórias, permitindo o retorno ao movimento de progressão do amadurecimento, mas podem ser crônicas, caracterizando uma patologia que impede ou bloqueia a progressão. Para Winnicott, a regressão é um conceito diferente do apresentado na psicanálise tradicional (regressão instintual), tem relação com a ideia de temporalidade. Para o autor, a regressão está relacionada ao processo maturacional (Winnicott, 1971f). Regressão, para Winnicott, inclui vários processos nos quais há reversão no amadurecimento, a fim de ser restabelecido algo na relação com o ambiente.

De acordo com Loparic (2014), para Winnicott, a regressão é, portanto, uma perturbação do progresso do desenvolvimento que está relacionado à evolução da psiquesoma, da personalidade, da capacidade de socialização etc. O indivíduo, quando regride, segue no sentido oposto ao da tendência à integração, e isso gera consequências importantes para o desenvolvimento, por exemplo, da personalidade e relacionamentos objetais. Quando as necessidades do ego não são atendidas, e a posição avançada é deixada para ser reestabelecida uma dependência infantil, anterior à independência já conquistada, a reversão indica o movimento que pode ter um sentido simplesmente defensivo, da independência para a dependência, em busca de algo.

No trabalho clínico, o analista trabalha com a regressão relacionada à dependência e reedita a dependência materna, permitindo que paulatinamente o paciente se desfaça do si mesmo falso, distorcido, que até então foi útil para compensar a falha ambiental na construção do eu sou. Nos casos mais graves, como acontece em pacientes psicóticos, é necessário regressões extremas para integrar não somente os relacionamentos, mas algo mais primitivo:

Exemplos desse tipo de regressão à dependência são regressões dos pacientes psicóticos, incluindo as regressões ao processo de nascimento. Elas envolvem experiências somáticas muito primitivas e buscam experiências integradoras, que não passam nem pela fantasia nem pelo simbolismo (1958a, p. 189; tr. p. 272). Finalmente, o estado de não estar vivo cheio de paz só poderia ser alcançado mediante uma regressão extrema, não defensiva ou reativa, para a condição de pré-dependência (1988, p. 132; tr. p. 154). Ela também 
propicia cura, mas não a cura de um relacionamento malsucedido, e sim de todo relacionamento, em particular da integração no tempo. (Loparic, 2014, p.12)

A regressão de modo geral aparece na clínica, na relação transferencial entre paciente e terapeuta, na qual uma posição mais integrada, avançada no desenvolvimento, retorna para uma relação mais dependente. A transferência identificada na dependência infantil tem a função de proporcionar que algo importante se restabeleça, auxiliando na integração de algo que o meio não atendeu anteriormente. Dessa forma, o terapeuta tem papel fundamental, já que estará em posição de sustentar o processo do paciente realizando o holding necessário (Loparic, 2014).

O setting apropriado para o atendimento das regressões à dependência não visa a recolocar na boa ordem temporal e causal os conteúdos vividos no passado e expulsos do tempo do sistema Cns., mas, pelo contrário, permitir (não induzir) que o que não foi vivido no passado seja vivido pela primeira vez no presente, no agora. Não se trata de propiciar dessa maneira satisfações compensatórias corretivas (1965b, p. 258; tr. p. 233), mas de oferecer ao paciente mediante participação no seu modo de ser a oportunidade de retomar, em primeira pessoa, o processo de amadurecimento. $O$ analista não se faz presente pela interpretação, mas psico-somaticamente, pela qualidade da presença e da atenção, e pelo comportamento, pelo modo de relacionamento, admitindo inclusive certos tipos de contato físico, "dando o colo", o seu divã tornando-se automaticamente também o seu colo (1958a, p. 258; tr. p. 350). Confrontado com os processos regressivos, o analista tem de estar disposto a facilitar que eles se realizem, sem que seja necessário torná-los conscientes. Sendo assim, o setting analítico, o conjunto de detalhes do manejo, torna-se mais importante do que a interpretação. (Winnicott, 1958a, p. 297; tr. p. 395). [sic] (Loparic, 2014, p.16)

No desenvolvimento fora da saúde, quando ocorre um distúrbio psicológico, podese observar a ocorrência de um tipo de imaturidade no crescimento emocional como, por exemplo, a dificuldade de se relacionar com o outro e com o ambiente, e uma submissão crônica (Winnicott, 1971g, 1984i, 1996f). A terapia acaba por auxiliar bastante nos conflitos e no processo de integração do paciente. Para que esse movimento ocorra, o terapeuta precisa estar presente, e se comunicar de uma maneira clara, cuidadosa, de modo que o paciente se sinta entendido, num encontro verdadeiro. O profissional entende que o paciente tem um processo, um ritmo, seguirá seu próprio caminho e que deverá, assim como a mãe, colocar o bebê no centro de sua atenção no tempo/espaço. Isto pressupõe também que o próprio terapeuta deverá, para participar profundamente deste processo, se refazer, se reinventar.

$\mathrm{O}$ analista precisa estar vivo, presente, comunicar-se com o paciente de maneira que o paciente se sinta entendido pelo analista. Isto não corresponde a, propriamente, uma atitude 'profissional', uma 'técnica', mas sim a uma maneira de acompanhar o paciente que coloca em ação a possibilidade humana de estar-com-o-outro. É interessante que Winnicott se refira a isto, marcando o fato de que uma psicoterapia corresponde mais a uma sustentação do que a uma intervenção técnica. (Fulgencio, 2016, p.65) 
Para avançar mais um pouco na compreensão da clínica winnicottiana, retomo agora os modos de ser/estar/relacionar-se no mundo tratado no item anterior. Aqui irei utilizar a classificação de Winnicott dos tipos de pacientes: 1) neuróticos; 2) deprimidos ou borderlines; 3) psicóticos; acrescentando agora o holding adequado para o manejo clínico. Winnicott faz uma distinção entre análise padrão, útil para os pacientes tipo "1" e análise modificada para os tipos "2" e "3":

No caso de pacientes que não chegaram à organização neurótica, sejam eles psicóticos, deprimidos ou borderlines, ou seja, os que tem problemas para chega a integrar-se num EU SOU e poderem viver a partir daí, o tratamento visa, em última instância, levá-los a essa integração; o que os lançaria para o campo dos problemas existenciais neuróticos. (Fulgencio, 2016, p. 76)

De acordo com Winnicott, os pacientes tipo "1" têm conflitos com a distinção entre o mundo interno (fantasias) e mundo externo (realidade). Costumam precisar lidar com suas ambiguidades, identificações, ou a sua existência enquanto pessoa inteira. As dificuldades deste tipo estão relacionadas às relações interpessoais, e a administração das dificuldades de se relacionar com o outro. Quando as angústias e os conflitos se tornam intoleráveis nas relações com o outro, o indivíduo utiliza defesas muito rígidas. $\mathrm{O}$ indivíduo em terapia, ao conquistar a posse do eu, passa a integrar em si impulsos amorosos e destrutivos, seguindo um movimento de destruir e consertar o que destruiu, consolidando, assim, valores pessoais, morais, chegando à percepção de ser e sentir-se uma pessoa inteira, que pode se relacionar com o meio e administrar seus impulsos na relação com o outro. Nesse sentido, o trabalho do terapeuta está, grosso modo, relacionado a ajudar o paciente nas distinções e nos esclarecimentos desses conflitos num setting em que o paciente revive os modos de amar (de estrutura neurótica) na relação com o analista (Fulgencio, 2016).

O terapeuta deve sobreviver aos ataques e aos impulsos amorosos para que seja possível o contato e a relação. De acordo com Winnicott (1968i), cabe ao terapeuta criar espaço para que o paciente possa descobrir algo por si próprio, tendo sempre o cuidado com as interpretações (o que seria uma pseudoanálise) que podem gerar o desenvolvimento de um falso self. A interpretação imatura e fora da área de sobreposição do brincar do paciente e do terapeuta será inútil ou provocar submissão.

Importante dizer que aqui é que a psicoterapia se dá pela sobreposição das duas áreas do brincar, a do paciente e a do terapeuta. A psicoterapia diz respeito a duas pessoas que brincam juntas. O corolário disso é que quando o brincar não se torna algo possível, 
o esforço do terapeuta volta-se para o resgate do paciente do estado de não ser capaz de brincar para um estado de ser capaz de brincar (Winnicott, 1968i ).

Os pacientes tipo 2 e 3, para Winnicott (1968i), são aqueles que não tiveram um cuidado suficientemente bom nas fases iniciais da infância e, por isto, não têm um eu sou integrado. Nesse sentido, o tratamento (ou profilaxia) está também relacionado aos cuidados ambientais, sendo necessário fornecer, na medida do possível, o cuidado de um ambiente saudável, possibilitando, dessa forma, integrações sem as intrusões que aniquilam.

O tratamento dependerá das especificidades clínicas. devido ao lugar em que se encontra o deprimido (neurose ou psicose), mas, em termos gerais, como estes pacientes têm problemas por serem recém-chegados na integração, enquanto indivíduos possuem problemas com a sua unidade e com a junção do amor e do ódio e do reconhecimento ainda inicial de sua dependência (Winnicott, 1955d). O holding, grosso modo, deverá ser realizado a fim de assegurar que o mundo do paciente não irá se dissolver, se destruir diante das experiências apresentadas pelo paciente, ou seja, o terapeuta deverá sobreviver ao paciente para que ele tenha segurança de se integrar durante o tratamento.

Os pacientes borderlines precisam integrar o falso self. Dessa forma, o analista deverá atuar integrando o falso self, de modo que ele seja deslocado para o papel secundário, operando para auxiliar o verdadeiro self somente quando for necessário. A ênfase sempre será em fornecer condições para que o paciente retorne

A uma relação de dependência intensa, adaptando-se à necessidade de viver uma dependência do ambiente a partir da qual ele pode ser a partir de si mesmo. Isto recolocaria o falso self em seu lugar, deixando o verdadeiro no comando, fazendo, pois, um tipo de integração onde antes havia dissociação. (Fulgencio, 2016, p.89)

Os cuidados psicoterápicos deverão estar relacionados à sustentação ambiental, reproduzindo, na medida do possível, um ambiente saudável de sustentação materno/paterno. Nas palavras de Abram (2000, p. 26), “o indivíduo não existe - o que existe é o indivíduo em relação ao mundo externo". Nesse sentido, Winnicott chama a atenção para o papel do setting no trabalho terapêutico, destacando que a falha ambiental vivenciada pelo paciente no início da vida pode ser curada a partir do que o setting oferece, como acolhimento, estabilidade e confiança.

As psicoses, problema psiquiátrico dos mais graves, advêm, para ele [Winnicott], de falhas ambientais nessa fase inicial; logo, o cuidado (curativo ou profilático) desse tipo de problema implica a retomada, com maior ou menor intensidade, desse tipo de sustentação ambiental: diz-se que, nesse momento, a mãe sustenta o bebê, tal como o sistema hidráulico sustenta um ônibus! (Fulgencio, 2016, p. 29) 
De acordo com Winnicott (1960c), a ansiedade nos estágios iniciais está relacionada à ameaça de aniquilação. Nesse sentido, o papel do holding é o de minimizar o potencial da invasão a que o bebê se encontra exposto.

"A ansiedade nesses estágios iniciais da relação mãe-bebê está associada à ameaça de aniquilação. É preciso esclarecer o que isso significa. Nessa posição caracterizada pela existência fundamental de um ambiente de holding, o 'potencial herdado' transforma-se na 'continuidade do ser'. A alternativa ao ser é a reação, o que o aborta e aniquila. Ser e aniquilação são as duas alternativas. $\mathrm{O}$ ambiente de holding, portanto, tem como sua principal função reduzir a um mínimo a invasão a que o bebê deve reagir, apesar da consequente aniquilação do ser pessoal". (Winnicott, 1960, p.47, citado por Abram, 2000, p. 31)

Nesse sentido, para os psicanalistas winnicottianos, a ideia principal acerca da terapia é que ela seja útil para que o sujeito encontre um modo de ser no mundo, um modo próprio, possível, um modo que permita que a vida valha a pena, mesmo que esse modo seja composto por sintomas e/ou limitações.

Não se trata de levar todos ao estado ideal de saúde, mas de encontrar - para cada um, dentro dos limites pessoais e sociais - um modo de ser possível no mundo, de maneira que o paciente possa ter uma vida que considere sua, real e possível, mas ainda, uma vida que valha a pena ser vivida! Winnicott aponta para o fato de que vivemos em algum lugar que não é nem o nosso mundo interno nem o mundo externo, mas num lugar onde é possível viver criando e encontrando a si mesmo e ao outro. Isto me parece importante de ser apontado, pois não se trata de levar a todos ao mesmo estado ideal de saúde, mas sim de encontrar um lugar para viver, mesmo que isto implique um conjunto de sintomas, um conjunto de limitações ou mesmo "anormalidades". Trata-se de encontrar um lugar possível para ser! (Fulgencio, 2016, p.77)

\subsection{Considerações sobre a atuação clínica junto a familiares em luto antecipatório em contexto domiciliar a partir do quadro da Psicologia Analítica com contribuições de Winnicott}

Como tratado anteriormente, para Jung a morte é algo esperado pelo ser humano, mas, em sua concepção, os humanos nunca estão completamente convencidos de que ela realmente ocorrerá. De fato, esta "marcha inexorável” (Jung, 2013c, p.361) nos coloca em contato com o sentido e o valor da vida, promovendo um processo de autorregulação em decorrência da qual questões supérfluas e preocupações de segunda ordem perdem a importância. Em contexto de luto antecipatório, a assimilação da perda se revela trabalhosa para todos.

Como tratado no capítulo 2 da primeira parte desta pesquisa, o ego é influenciado por defesas, equilibrando, por exemplo, momentos de negação e aceitação (Rando, 1986). O movimento de negar a morte e aceitá-la consiste em polaridades que são visitadas durante todo o período no qual é experimentado o luto antecipatório. Segundo Rando 
(1986), o sofrimento antecipatório não aumenta necessariamente com a aproximação da morte em si. Neste processo, o indivíduo, no mundo ideal deverá integrar os aspectos da perda anunciada para que não haja risco de um luto pós-óbito complicado, contudo é essencial deixar claro que a dor psicológica não poderá ser extinta do processo, visto que o rompimento de um vínculo afetivo importante é sempre marcado por sofrimento de alguma ordem. Nesse sentido, o objetivo do manejo está relacionado com a atenuação do impacto, com integrações e busca de sentido individual e coletivo.

Durante o atendimento de pessoas que vivenciam o processo de luto antecipatório, é importante possibilitar espaços para que os familiares verbalizem as dificuldades e reflexões sobre decisões a serem tomadas, desejos, questões objetivas e subjetivas ainda interditadas. Este é um exercício de enfrentamento doloroso no qual o ego poderá transcender do lugar conhecido. Aqui estamos construindo um trabalho que vai além da compreensão intelectual do processo de morte de um ente querido. A proposta não é focar apenas nos aspectos cognitivos relacionado às comunicações, informações sobre as condições clínicas do paciente etc. A proposta é fomentar a busca de sentido individual e coletivo (familiar) para esta morte, que foi anunciada e vivida cotidianamente. Aqui serão trabalhadas contradições, ambivalências, os conteúdos que emergirem das polarizações vivenciadas, a elaboração de aspectos individuais apoiando a ressignificação da vida a partir da doença, da morte, da finitude da vida etc. Em resumo: quando o familiar começa a elaborar as questões internas a partir da compreensão de que existe uma doença que irá levar à morte uma pessoa próxima, começa-se um processo de ressignificação da vida. Nesse processo, o profissional de psicologia precisa estar atento aos movimentos idiossincráticos relativos à individuação do sujeito, mas também aos processos de luto coletivo, nos quais são incluídos aspectos relativos à ritualização da passagem e de ressignificação do movimento vida-morte-vida no sistema familiar.

Não é possível elencar todas as questões que podem surgir na clínica quando atendemos indivíduos em luto antecipatório, mas, de modo geral, quando acontece um luto antecipatório por doença crônico-degenerativa de um ente que demandará cuidados domiciliares por longos períodos, uma mudança que não pode ser negada como implacável é apresentada. É importante salientar que a técnica a ser utilizada pelo psicólogo/psicóloga deverá ser escolhida a partir do diagnóstico situacional. Portanto, a intervenção poderá ser individual, em pequenos grupos ou com toda a família, utilizando o método de grupo vivencial ou processual. 
O trabalho com a dor psíquica envolve o acolhimento e o encorajamento para atravessar todas as dificuldades e interdições envolvidas. As transformações que ocorrem na vida dos familiares são aos poucos reorganizadas. Neste momento, destacarei o último resultado da pesquisa indicando orientações sobre a atuação clínica junto a familiares em luto antecipatório em contexto domiciliar sob o ponto de vista da Psicologia Analítica com contribuições de Winnicott. Aqui apresentarei uma proposta com algumas recomendações que poderão dialogar e orientar, em seu aspecto macro, o manejo do luto familiar no contexto apresentado, deixando claro que todos os conceitos e fundamentos tratados neste item já foram abarcados anteriormente no corpo da tese. Não pretendo oferecer uma norma, um manual, mas sim uma proposta que poderá ser utilizada para que psicólogos e psicólogas domiciliares possam construir diálogos com o trabalho aqui proposto.

A tarefa de atender um grupo familiar que vive a experiência de luto antecipatório em domicílio é complexa. O aumento da utilização desse velho-novo modelo de intervenção domiciliar tem sido estruturado e pensado em níveis de políticas públicas, por ser um caminho possível diante do aumento do número de pessoas que tem desenvolvido doenças crônico-degenerativas, e economicamente viável, para que os sistemas de saúde possam manter os cuidados de pacientes crônicos, mesmo fora dos hospitais. A crescente prevalência das doenças crônico-degenerativas na atual tendência epidemiológica no Brasil impõe mudanças a um número cada vez maior de famílias que passam a vivenciar o luto antecipatório por doenças que poderão durar longos períodos.

Este é um desafio para a Psicologia, já que em cada família encontramos um universo diferente, específico em sua construção e subjetividade, mas que também é coletivo e, em sentido amplo, socialmente comum. Quanto mais cresce o número de famílias acometidas por este processo, maior será a demanda psicológica. Nesse sentido, torna-se imprescindível o feeling, a empatia e a flexibilidade do psicólogo para construir o plano terapêutico com a família que se está atendendo. Passarei agora, após realizado esse primeiro ajuste, a pontuar algumas orientações sobre o atendimento domiciliar, utilizando o quadro da Psicologia Analítica e as contribuições de Winnicott.

No início do trabalho, antes da primeira visita domiciliar, é recomendável que o psicólogo acesse junto à equipe multiprofissional e/ou ao prontuário de saúde as informações acerca do histórico clínico do paciente: qual o diagnóstico? Quais as características deste adoecimento? Quais sequelas e desenvolvimentos da enfermidade? Quem é o cuidador principal? Há quanto tempo o paciente está vivenciando este processo 
de adoecimento? Estes pontos são essenciais para o profissional começar a entender a dinâmica trazida pela doença crônica naquela família em específico.

A primeira visita pode ser agendada pelo profissional, por algum familiar ou pela equipe que percebe a necessidade de uma avaliação psicológica. Essas variações ocorrerão por se tratar de um atendimento que pode ser realizado por um profissional autônomo (requer combinação de pagamentos) ou membro de equipe de cuidados multiprofissionais de iniciativa pública ou privada (requer combinação de pagamentos).

No primeiro momento, o que pode durar algumas visitas, deverão ser realizadas entrevistas para levantamento de um diagnóstico situacional (envolvimento da família no cuidado, realidade social e econômica, religiosidade, dinâmica familiar, identificação de recursos psicológicos diante do contexto vivenciado etc.), e à construção de um bom rapport com os cuidadores principais, e familiares que estiverem presentes. O psicólogo deve estar atento e ser flexível, já que o atendimento pode ser realizado com um ou mais familiares. É importante uma interação respeitosa e ponderada do profissional, que deverá ser cauteloso por estar em um ambiente privado e a família pode ficar desconfortável com a presença do "doutor" ou da "doutora", por se sentir exposta em sua situação social, econômica e outros aspectos, como bem recomendou Laham (2004).

Após esse primeiro momento de entrevistas, o/a psicólogo/psicóloga avaliará junto à família os encaminhamentos necessários, e dará início ao tratamento em $\mathrm{si}^{20}$. Em caso de identificação de dificuldades e/ou risco com a saúde mental, o psicólogo poderá indicar o atendimento em grupo ou individual. Em caso de indicação de atendimento em grupo, será feito um convite formal pelo profissional por meio de telefonemas, cartas ou o meio de comunicação mais indicado na época. O atendimento ao grupo familiar ocorrerá com a família nuclear ou extensa, de acordo com a necessidade avaliada no caso. A participação deverá ser livre, e todos os envolvidos deverão ser efetivamente convidados. É mais indicado que o grupo ocorra em um horário compatível com a agenda da maioria, e que seja um grupo fechado. Contudo, se algum membro que ainda não havia se interessado em participar decidir entrar, a possibilidade será tratada com o grupo em si, durante as sessões. O psicólogo precisa abrir espaço eventualmente para sessões individuais em outros horários para atender às demandas pontuais que aparecerem, tomando-se as devidas precauções técnicas com as fantasias e as persecutoriedades dos outros membros.

\footnotetext{
${ }^{20}$ Lembrando que neste primeiro momento a escuta dos profissionais pode funcionar como intervenção preventiva e de promoção em saúde mental.
} 
As sessões com o grupo familiar serão iniciadas com a construção das regras e contratos acerca do setting de atendimento. Serão abordadas a questão do sigilo, liberdade de participação, direito ao silêncio, exercício de não julgamento perante a fala do outro, contrato de horário, controle do setting, regras de entrada e saída do atendimento, objetivos, decisão de quem estará responsável pelo paciente durante os atendimentos, melhor local para realização do processo em si e outros balizadores. O atendimento poderá ocorrer no domicílio da família (em ambiente razoavelmente isolado e confortável, onde caibam todos os participantes) ou em outro espaço previamente combinado (por exemplo, em equipamentos sociais no território em que vive a família).

Estabelecidos os contratos, pode-se iniciar o grupo terapêutico. É importante apontar que essas indicações não deverão ser seguidas em sequência, já que cada família iniciará seu processo por um caminho próprio. Nesse sentido, o psicólogo/a psicóloga deverá oferecer um acolhimento ambiental, um holding específico para cada caso. Para um bom desenvolvimento dos trabalhos, é necessário lançar mão do clima de Héstia, apontado anteriormente. O terapeuta alinhado com as características simbolicamente representadas pela deusa da mitologia grega Héstia poderá promover um ambiente caloroso que acalenta, aquece, permite a transmutação sem queimar, e promove o encontro de oponentes "em volta da lareira". Isso não garante que tensões, espelhamentos malignos, como apontado na parte II, não ocorrerão. Dessa forma, o terapeuta deve estar atento à movimentação individual e grupal, utilizando as técnicas e pilares referentes ao manejo do trabalho em grupo.

$\mathrm{Na}$ relação terapeuta-paciente ou mesmo terapeuta-grupo, o psicólogo deve abdicar de suas demandas para atender àquelas específicas do indivíduo ou indivíduos que cuida. Este estado confiável e permanente oferecido pelo terapeuta-ambiente deve ser individualizado para cada paciente e não deve ser invasivo nem negligente. O terapeutaambiente funciona de certa forma como um objeto transicional e tem a função de auxiliar o processo de integração do paciente até o ponto em que este (estes) possa (possam) se cuidar sozinho, sem a figura do terapeuta presente. O terapeuta-ambiente precisa estar completamente presente, oferecendo um encontro verdadeiro e também precisa utilizar uma comunicação adequada. Na construção deste holding, é importante que o terapeuta esteja disponível para se reinventar sempre que for necessário para uma sustentação "suficientemente boa" (Fulgencio, 2016).

Esta sustentação, em condições adequadas, será continente, um ambiente protegido para o desenvolvimento do grupo, um vaso alquímico. Esta qualidade é 
importante para que haja transmutação sem perda desnecessária de energia. O grupo psicoterapêutico deve ser bem conduzido a fim de ser um ambiente que tolere as pressões sombrias que emergem em forma de projeções, julgamentos, medos, angústias etc. O/a psicólogo/psicóloga precisa estar permanentemente atento às polarizações, transferências, atitude simbólica, ao desenvolvimento do eixo ego-self de cada participante e também à construção ou identificação do self grupal, princípio ordenador individual e grupal capaz de conter os inúmeros potencias de vir-à-ser, de ser o que realmente se é. Para isso, poderão ser utilizadas técnicas como materiais expressivos, mitos, histórias folclóricas, lendas regionais, sonhos, histórias da família, construção da árvore genealógica e inúmeras outras que auxiliem no processo. Como dito nos capítulos anteriores, o fio condutor será o processo de individuação e os atravessamentos impostos pelo luto antecipatório neste processo. Ou seja, o grupo terapêutico, "hermeticamente fechado", como em um vaso alquímico poderá trazer ampliações e integrações valiosíssimas para se lidar com o luto e com o processo de individuação.

De acordo com os constructos winnicottianos, (Winnicott, 1971g; 1984i; 1996f), os modos de ser e estar no mundo estão relacionados à noção do desenvolvimento do paciente (na saúde e na doença). Tais constructos podem ter implicações nas transferências e na dinâmica dos encontros dentro dos grupos terapêuticos, assim como apontado por Zinkin (1998). Na saúde, o indivíduo age a partir de si mesmo e adapta-se às mudanças da vida sem perder a ação espontânea, sendo capaz de reparar danos, tendo a noção de responsabilidade na interação com o mundo e realizando o autocuidado. Faz parte também o lidar com sentimentos como culpa, momentos de depressão e alegria. Contudo, na doença, a imaturidade no desenvolvimento aparece na dificuldade em se relacionar com o entorno afetivo e com o ambiente, sendo comum a ação estereotipada e submissa. Nos dois segmentos o terapeuta pode ajudar auxiliando o paciente a lidar com as tensões da vida e, também, nas integrações do si mesmo.

A interação indivíduo/grupo, realizada pela dinâmica face a face, sem hierarquia de poder com o terapeuta, auxiliará a construção dialética, permitindo a conexão familiar para lidar com a vivência da intrusão advinda da morte anunciada e suas consequências. Esse processo não é nada linear e precisará de tempo para ocorrer. Tempo em que o psicólogo dará sustentação ambiental, aos moldes do holding materno, tratado por Winnicott em sua obra, promovendo uma escuta profunda e simbólica. Como dito anteriormente, nesse processo é indicado o uso simbólico de mitos, mas também de histórias familiares que ajudem na identificação do legado, de rituais familiares para o 
enfrentamento do luto, incluindo os rituais ligados à religiosidade, ou outras manifestações da identidade coletiva daquela família. O psicólogo legitimará os insights e encorajará o partilhar, exercício que poderá contribuir na construção ou reconstrução de vias de comunicação que estiverem interditados pela própria história da família, ou pelo tabu de se tratar da morte no cotidiano.

O processo de luto antecipatório é uma passagem que pode promover crises de diversas medidas, que podem transcender o lugar conhecido. Apesar do ser humano na contemporaneidade ter perdido o vínculo com os rituais de passagem em seu sentido mais profundo, eles são imprescindíveis para trazer significado, enfrentamento das limitações auxiliando no amadurecimento e atualização da alma. O processo de luto antecipatório será compreendido como um ritual de passagem, um ritual de transição, que poderá agir na ampliação de consciência realizada com afetividade, de ressignificação da vida, na qual atuará a função transcendente.

Nesse sentido, deve-se ter atenção aos símbolos e imagens que emergem na construção de pontes entre conteúdos inconscientes e conscientes que auxiliem no enfrentamento da vivência do luto. Além de trabalhar o sentido de integração do indivíduo para que ele possa funcionar como uma pessoa inteira, os aspectos da morte e da finitude deverão ser cuidadosamente trazidos para o trabalho.

O grupo terapêutico passará a ser conduzido com bastante atenção pelo coordenador e deverá ser desenvolvido com o propósito de escuta, acolhimento, ritualização do processo vida-morte-vida e do contato simbólico da presença da morte nas esferas consciente e inconsciente. Cada membro da família pode se encontrar em um momento do desenvolvimento psíquico, e nem todos podem estar em franco processo de individuação. Fato este que deve ser levado em consideração pelo terapeuta. Mesmo com as possíveis diferenças, a proposta é que a família encontre um sentido para a dor que vivencia, bem como poder ritualizar a dor e ressignificar a morte anunciada. Diante do tabu da morte, a Psicologia pode dessa forma ter um posicionamento ativo, seja acolhendo, auxiliando na desinterdição do tema nas vias de comunicação da família, ajudando na busca de elaboração e sentido para suas experiências, visto que, segundo apontado anteriormente, para Jung e colaboradores, o contato com a morte pode ser transformador. Poder falar com mais liberdade sobre as questões relacionadas a morte é também transformador.

Quando existe uma situação de intrusão, todos que compõem a família-ambiente, o grupo-ambiente, ou a terapia-ambiente devem retomar a sustentação ambiental. Nesse 
sentido, diante de uma realidade na qual existe muita tensão, o ambiente deve dar suporte, resistindo e mantendo-se às ações tanto de amorosidade quanto de destrutividade. Esse holding traz confiança ao enlutado, mesmo sendo invadido pela ameaça da morte de um ente querido. Será que a vida dará conta de mim? Será que a minha família será forte o bastante? Será que o terapeuta suportará mesmo em uma situação cuja dor é tão abissal?

Retomando a fase da dependência relativa, temos que aqui a criança desenvolve a capacidade de interagir com o ambiente, brincar (fenômeno transicional) e tolerar a ausência do adulto e certas perdas. Aqui desenvolve-se a capacidade paradoxal de ser capaz de ficar só mesmo que acompanhado. Esta capacidade tem origem nas experiências integradas até então, este desenvolvimento é imprescindível para que a perda que se anuncia seja encarada como a perda de parte do seu mundo e como a perda do mundo inteiro, como pode acontecer com pacientes psicóticos que possuem uma fragilidade psíquica importante. Uma contribuição importante da teoria de Winnicott (1971f) é com relação à compreensão de que, mesmo tendo alcançada a maturidade individual, ainda existe uma oscilação entre a autonomia e a dependência.

A indicação do uso de material expressivo e/ou o uso da escuta simbólica está ancorada na compreensão de que o inconsciente sabe mais que a consciência, e poderá ofertar saídas e integrações importantes. A transformação, para Jung, acontece quando contatamos com o inconsciente. Em ambiente psicoterapêutico são utilizados instrumentos e manejos para tratar questões profundas como as sombras familiares, a fim de integrar e ressignificar a perda, a pessoa perdida, o vínculo e outras condições que são vivenciadas tanto na dinâmica progressiva quanto regressiva da libido.

No atendimento individual, verificamos dois sistemas que se comunicam: um representado pela psique do paciente e outro pela psique do terapeuta. No atendimento em grupo familiar, temos não só uma soma, mas uma sobreposição de sistemas, um self grupal (Freitas, 2005; Byington, 2005). O self grupal constela com os símbolos que emergem, atuando e reverberando também nos processos individuais. Validar sentimentos tem também um aspecto curador. $\mathrm{O}$ sentido de pertencimento e a legitimação dos processos individuais e coletivos agem de modo curativo nesse ritual de passagem.

Para encerrar minhas considerações sobre o manejo, apresento a questão da utilização do ritual de passagem no contexto terapêutico e a utilização de mitos em grupo e de material expressivo.

A valorização do ritual é encontrada em Jung (1950/1980), em revisão de uma palestra de 1939, na qual afirma que a regressão psicológica no grupo é inevitável, mas que ela 
pode ser parcialmente neutralizada pelo ritual, que coloca no centro a experiência de algo sagrado, com que o indivíduo deve estabelecer uma relação de interesse e atenção. Nesse mesmo texto, Jung faz algo raro em sua obra: destaca elementos positivos da vivência grupal, afirmando que ela pode conferir ao indivíduo coragem, apoio e dignidade. E, no prefácio ao livro de Toni Wolff (Jung, 1959/1974), comenta que o valor espiritual e moral de um grupo é avaliado pelo valor médio de seus membros individuais, sem, necessariamente, haver uma experiência regressiva e massificante do grupo. (Freitas, 2005, p. 54)

Quando a morte acontece em nossa sociedade, o ritual do velório se faz presente. Este é um período no qual podemos dividir a perda com a comunidade a qual pertencemos e começar a atualizar em nós mesmos o rompimento do vínculo com a pessoa que morreu. Quando uma pessoa morre, todos sabemos mais ou menos o que irá acontecer. Temos uma tradição no ocidente e cada comunidade tem uma série de comportamentos e noções orientadoras, como, por exemplo, a forma adequada de se portar em um velório, o tom de voz, o tema das conversas, o que se oferecer de alimento, as orações para confortar os que estão em sofrimento. Enfim, de uma maneira ou de outra, existe um ritual que constitui esse momento.

No contexto de morte anunciada, não existe nenhum ritual social para se oferecer aos familiares. De acordo com Zimmermann (2005), no transcorrer da vida humana, existem muitas fases e passar de uma para outra demanda modificações e, eloquentemente, possíveis crises. São bem conhecidos alguns rituais que celebram e marcam a transição de uma fase para outra. Esses rituais podem estar relacionados com vários tipos de mudanças como, por exemplo, a mudança na estação do ano em certos povos, bem como em mudanças para outra fase da vida em outros. O Festival de Beltane, é um destes. De origem celta, o ritual festivo marca a primavera ${ }^{21}$ e a fertilização da terra. Este ritual representa a fecundação simbólica da Terra na qual acontece a integração entre o masculino e o feminino com o intuito de se honrar as diferenças das forças que compõem o universo e preparar para o plantio (Matheson \& Tinsley, 2016; Pinheiro, 2011). Nesse sentido, as mudanças da estação no meio campesino são vividos de modo profundo e significativo já que na nova estação a comunidade mudará seu ritmo e suas tarefas que em geral estão relacionadas ao plantio, colheita etc. O antigo festival, comemorado até os dias atuais tem a função de auxiliar na atualização no campo psicológico individual, coletivo e na relação com o meio/natureza.

Outro exemplo que gostaria de apresentar é um ritual indígena que ocorre no Brasil, mais especificamente no povo Tikuna, que tem o intuito de auxiliar na iniciação

\footnotetext{
${ }^{21}$ Em sua origem marcava o verão (Pinheiro, 2011).
} 
feminina. Neste ritual profundo de puberdade as meninas serão preparadas e devem estar prontas física, fisiológica, psíquica, social e espiritualmente para a nova vida adulta (Soares, 2002). Este processo é repleto de simbolismos e transferência de cultura. Segundo Zimmermann:

Durante esses acontecimentos muitas sociedades celebram rituais diferenciados que têm o objetivo de ajudar o indivíduo a superar as crises. As atuações ritualísticas, tanto entre os povos primitivos como para o homem contemporâneo, têm um propósito religioso, baseando-se em temas mitológicos e arquetípicos; expressam suas mensagens simbolicamente e envolvem totalmente o indivíduo. Transmitem uma sensação de significado elevado para este e, ao mesmo tempo, apoiam-se em representações adequadas ao espírito dos tempos. Seja qual for o contexto da vivência ritualística, vida moderna ou vida primitiva, a transformação alcançada pode significar uma ampliação de consciência, uma mudança estrutural da personalidade ou o ingresso num novo status de vida na comunidade, promovendo o amadurecimento do indivíduo. (Zimmermann, 2005, p.32)

Os rituais dentro da perspectiva da Psicologia Analítica são recursos de defesa para lidar com a ansiedade gerada pelo contato com as grandes forças do inconsciente. Frente à ameaça de desordem, o ser humano cria, instintivamente, os rituais como barreiras que auxiliam o processo de renovação e transmutação.

Whitmont (1991) defende a necessidade de desenvolvermos rituais significativos na atualidade, uma vez que os rituais tradicionais perderam sua força. O novo ritual estaria voltado para a individualidade em formas interpessoais e grupais. Mas, aponta, para ser genuíno este novo ritual deve ser "descoberto" e não fabricado. A função do ritual é oferecer possibilidade de aceitação e contenção dos afetos mobilizados, transformando a sua energia em formas de cooperação. O ritual é visto como um jogo dramático, um ato lúdico, mas que deve ser vivido como significativo, caso contrário não promove transformação. (Parisi, 2009, p.63)

Para Sá (2011, p. 104), “a vivência simbólica de morte significa confronto com a sombra ao desconhecido, assusta, mas gera autoconhecimento". Nesse sentido, como bem apontado por Parisi (2009), a elaboração simbólica é um processo dinâmico entre consciente e self e o efeito é gerador de transformações na personalidade. Em seu trabalho com grupo vivencial aplicado a mulheres enlutadas pela separação conjugal, Parisi (2009) utiliza o conceito de ritual para promover a transformação de conteúdos psíquicos e do sofrimento vivenciado na perda.

A imersão favorecida pela vivência através de trabalhos com imaginação ou com materiais plásticos cria uma atmosfera diferente no grupo, algo que abre para uma dimensão mais sutil onde a intuição, os sentimentos e as sensações corporais são solicitados a participar deixando em segundo plano os aspectos cognitivos ou verbais. Muitas vezes presenciei uma atitude de reverência e profundo respeito do grupo para com os trabalhos produzidos pelos outros membros, assim como pelas suas colocações pessoais, num clima que toca o que podemos chamar de "sagrado", cerimonial. A utilização combinada do referencial arquetípico presente nos contos e mitos, que fornece o pano de fundo coletivo, com as técnicas expressivas parece ser facilitadora da criação deste "campo simbólico" que sai do tempo e do espaço profanos e ingressa na dimensão 
do "sagrado". No grupo assim concebido, como espaço ritual, há a possibilidade de trazer ao concreto o que foi experienciado internamente, e esta é uma das funções do ritual, segundo Johnson (1989, p.119). Ao fazer alguma coisa para expressar o símbolo, diz Johnson, "alguma coisa que envolva nosso corpo e nossas emoções - o símbolo se torna uma realidade viva para nós". Para este autor, do ponto de vista psicológico, o ritual é o comportamento simbólico cumprido conscientemente e é uma importante ferramenta para conectar o ego ao Self. Recomenda fazer algo concreto com os sonhos e com a imaginação ativa, realizando pequenos atos simbólicos como uma representação física das imagens e do sonho. (Parisi, 2009, p.64)

Nesse sentido, a vivência simbólica da morte, bem como sua ritualização podem auxiliar na conexão do eixo ego-self, trazendo como apontado por Jung para compreensões que vão além dos aspectos intelectuais. Para tanto, podemos utilizar, como Parisi bem exemplificou, o trabalho com material expressivo, contos, mitos e sonhos dos elementos do grupo para auxiliar nesse processo de ritualização. Nesse sentido, diante da grande sombra da morte, a família pode criar novos rituais a partir do movimento de iluminar a situação e as dificuldades vividas e em alguns casos nem percebidas visto que o ser humano moderno se encontra desconectado de seus próprios processos e pactuado com o racionalismo científico. Jung (2006) orienta que a parte mítica do ser humano reivindica o acesso ao inconsciente, aos sentimentos, atividades vitais e saudáveis para a integração de aspectos profundos e férteis. Este processo simbólico e ritualístico que é, ao mesmo tempo, individual e grupal, deve ser criado, não podendo ser pré-moldado.

O que se é, mediante uma intuição interior e o que o homem parece ser sub specie aeternitatis [sic] só pode ser expresso através de um mito. Este último é mais individual e exprime a vida mais exatamente do que o faz a ciência, que trabalha com noções médias, genéricas demais para poder dar uma ideia justa da riqueza múltipla e subjetiva de uma vida individual. (Jung, 2006, p.29)

Dessa forma, a orientação do manejo da Psicologia Analítica não inclui apenas o ser humano coletivo, médio, mas a faceta mítica. Existem inúmeras técnicas que resgatam o trabalho com o simbólico. Como dito anteriormente, o trabalho com imagens de mitos, conto de fadas, sonhos, materiais expressivos em grupo ou individual acessa conteúdos e coloca em movimento a energia psíquica bloqueada. Seguem dois exemplos destacados do trabalho de Parisi (2009) a fim de ilustrar ainda mais os caminhos possíveis do atendimento em grupo de familiares enlutados: após o trabalho com a narrativa de mitos ou contos de fadas pertinente ao desenvolvimento do grupo, a terapeuta oferecia materiais plásticos para que as mulheres de seu grupo pudessem expressar os conteúdos mobilizados, bem como registrar as imagens que mais chamaram a atenção. Em seguida, esses conteúdos eram apresentados ao grupo e elaborados na partilha. O acesso aos conteúdos psicológicos e a possibilidade de verbalização desses conteúdos é fundamental 
em um grupo vivencial. De acordo com Freitas (1990), a palavra é uma via importante para a elaboração dos símbolos, é a partir da fala que se integram os conteúdos inconscientes com a consciência.

Outro exemplo foi o trabalho com o tema do arquétipo do curador-ferido, no qual Parisi propôs que cada mulher refletisse sobre suas feridas psicológicas originadas da separação conjugal e escrevesse anonimamente esta dor em uma frase num papel. Na sequência, estes papéis foram aleatoriamente distribuídos entre o grupo. A pessoa que recebeu o papel realizaria uma reflexão podendo dar conselhos, sugestões e/ou dizer o que lhe vinha à mente ao ler sobre a questão apontada. Desse modo, uma mulher (ferida) receberia um bálsamo (curativo) de outra por meio da verbalização das considerações realizadas no decorrer da dinâmica. O exercício teve efeito de legitimar os processos internos, espelhamentos, e vivência retroalimentadora tanto da mulher ferida, quanto da comentadora, sendo que ambas puderam acessar o arquétipo do curador-ferido:

$\mathrm{O}$ arquétipo do curador ferido precisa ser ativado no paciente para que a partir de dentro sejam acionadas as próprias forças curativas, um processo que é facilitado pela atitude do terapeuta ao estar em contato com o pólo ferido do arquétipo do curador em si próprio. Parceiras de dores semelhantes, as integrantes do grupo vivenciavam o que Hall (1992, p.93) expõe: '[...] a cura das feridas dos outros produz um efeito terapêutico recíproco nas próprias lesões dolorosas daquele(a) que cura' [sic]. (Parisi, 2009, p.192)

Para Winnicott, segundo Phillips (1988) a relação com o outro ou os outros é o que possibilita o encontro consigo mesmo, ou seja, o encontro com a mãe, com a cultura, com os grupos é que pode facilitar o crescimento do ser. Como dito anteriormente, o brincar é o motor da vida em grupo (Fulgencio, 2017) e é por meio do brincar que somos iniciados, conduzidos nas e para as relações grupais (Winnicott, 1968i). Nesse sentido, as dinâmicas e técnicas funcionam como o terceiro elemento, assim como o brincar. Ainda que conduzida a dinâmica, ela permite que algo novo seja encontrado no outro e em si mesmo, possibilitando ao membro do grupo terapêutico ressignificar questões importantes, com leveza, mas também com profundidade.

Segundo M. V. Catta-Preta, "quando temos passagens importantes na vida, é necessário ritualizar, se você não ritualiza fora, o sonho ritualiza dentro" (comunicação pessoal dia 27 de novembro de 2019). Assim, ritualizar e trabalhar com os símbolos em perspectiva grupal pode auxiliar na busca de integrações importantes para a elaboração desta fase da vida. $\mathrm{O}$ espaço terapêutico pode atualizar os processos individuais e grupais enquanto família. Este contato, caloroso e espontâneo, é fértil para o lidar com a morte anunciada e auxiliar na elaboração de significados e sentidos para este contexto. A presente tese tenta sanar parcialmente as lacunas existente na compreensão e no manejo 
do luto antecipatório de familiares que vivenciam a experiência de uma morte anunciada por adoecimento crônico e crônico-degenerativo de um familiar que esteja em cuidados domiciliares. É importante dizer que existe muito a ser sistematizado e construído, novas pesquisas sobre o assunto são necessárias. 


\section{CONSIDERAÇÕES FINAIS}

O enfoque teórico desta tese foi necessário para que fosse possível consolidar conceitos e reflexões, visando fornecer ferramentas instrumentais clínicas que pudessem ser úteis aos profissionais que atuam neste campo, muitas vezes sem ter tido acesso a treinamento adequado, em atenção domiciliar. Esta pesquisa nasceu de minhas buscas em compreender melhor como a Psicologia poderia cuidar dessa demanda. Não a demanda conveniente, óbvia, que está ali a um passo de ser detectada. Minhas reflexões nasceram do que ainda era invisível para mim.

O programa de atendimento domiciliar onde eu trabalhava funcionava em horário comercial e geralmente atendíamos o cuidador principal, além do paciente que estava gravemente adoecido, é claro. Os demais familiares sempre estavam fora, no trabalho, na escola, e estes, por uma questão de relógio, eram excluídos da assistência.

Vez ou outra conseguia encontrar alguém saindo apressado, e ciente da situação familiar, eu ficava me questionando o que poderia estar acontecendo internamente com eles. Em certas oportunidades, eu conseguia abordar brevemente um ou outro, enquanto destrancavam o trinco do portão: - Você está bem? Quer conversar um pouco?

Vi muito sofrimento que poderia ser acolhido, cuidado. Eu desejava alcançar o que ainda ficava oculto, intocado, pensar fora do quadro conveniente da lógica de setting terapêutico. Queria abrir espaço para o acolhimento do sofrimento daqueles que constelavam na rotina familiar, mas que, por uma série de impossibilidades (objetivas e subjetivas), talvez não pudessem acessar o que realmente sentiam, porque não havia tempo, não havia lugar para esse turbilhão de sentidos e sentimentos... Esta impressão continuou ficando mais forte e, nos velórios, quando eu ia dar as condolências e os abraços calorosos e presentes em nome da equipe, via uma série de pessoas que conviviam na casa dos meus pacientes e cuidadores principais em profundo e dilacerante sofrimento. Uma série de questões me inquietavam: Como nós, da psicologia, poderíamos fazer essa busca ativa em saúde mental? Como nós poderíamos agir diante do sofrimento familiar? A dor psicológica que eu via era uma dor de quem está sozinho, dor de gente "Atena", com escudos, espadas e armaduras, mas com um coração solitário, vulnerável. Uma dor 
de gente que vai para vida, faz sua coisa, luta para valer, mas que tem medo do que pode ocorrer com as sombras da noite... porque, quando a gente fala em ameaça de morte de um ente querido, estamos falando de sombras da noite. E, por incrível que pareça, essa situação não pode ser vivida coletivamente, porque a morte, enquanto um tabu, engessa a troca, o pedido de colo, o desabafo. No processo de individuação, vida e morte são complementares, dialéticas, compensatórias... A morte, durante a vida, atravessa o sujeito literal e simbolicamente e é aí que nós, da Psicologia, podemos atuar.

Hillman (1998) comenta que estamos caminhando para uma hipertrofia de Hermes, em que o espaço cibernético, os CD-ROMs, telefones celulares e realidades virtuais oferecem-nos, a qualquer momento, inúmeras possibilidades de conexão com o "lá fora". Para compensar tal desequilíbrio, necessitamos, talvez mais do que nunca, da qualidade centralizadora, intimista e circular de Héstia, que permite habitar nosso corpo, nosso tempo, nosso espaço, nossa interioridade, nossos significados, nossa história. (Freitas, 2005, p. 66).

De acordo com Tiago Alves (T.P. R. Alves, comunicação pessoal 09 de julho de 2020) Jean Shinoda fala de Hermes e de Héstia. "Hermes é o deus da comunicação, da extroversão, do 'mundo lá fora'. Héstia, sua esposa é a deusa que faz com que a casa se torne um lar, ela é quem cuida calorosamente do "mundo de dentro". A energia centrípeta de Héstia deve ser vivenciada para que haja a interação dos dois aspectos complementares. Hermes não pode atravessar a soleira da porta, Héstia não sai para o externo, mas é importante que a unilateralidade da extroversão de Hermes, tão presente na atualidade, deva ser compensada com a presença, a nutrição e o calor de Héstia”. Nas palavras de Jean Shinoda Bolen:

Desde os tempos gregos as culturas ocidentais têm enfatizado a dualidade, uma divisão ou diferenciação entre masculino e feminino, mente e corpo, logos e eros, ativo e receptivo, que depois se tornaram valores superiores e inferiores, respectivamente. Quando Héstia e Hermes eram ambos honrados nos lares e templos, os valores femininos de Héstia eram os mais importantes, e ela recebia as mais altas honras. Na época havia uma dualidade complementar. Héstia desde então foi desvalorizada e esquecida. Seus fogos sagrados não são mais cuidados e o que ela representa não é mais honrado. Quando os valores femininos de Héstia são esquecidos e desonrados, a importância do santuário interior, interiorização para encontrar significado e paz, e da família como santuário e fonte de calor ficam diminuídos ou são perdidos. Além disso, o sentimento de uma ligação básica com os outros desaparece, como desaparece também a necessidade dos cidadãos de uma cidade, país ou da terra se ligarem por um elo espiritual comum. (Bolen, 1990, pp. 168-169)

É exatamente desta "ligação básica" que se trata minha proposta. Se as pessoas estão excessivamente conectadas com o mundo externo, com rotinas de trabalho, acessos infindáveis às redes sociais e mídias em geral, no momento do luto antecipatório, impreterivelmente, é preciso sanar esse desequilíbrio e acessar a qualidade intimista, 
familiar e calorosa de Héstia. Este princípio permite que voltemos ao nosso corpo, à nossa casa, às conexões do mundo interno. Nesse sentido, se a família não consegue realizar este movimento por si mesma, pode ser auxiliada por um profissional da psicologia.

E esta foi justamente a proposta desta pesquisa: contribuir para a ampliação e aprimoramento das práticas psicoterapêuticas destinadas ao cuidado com familiares que estejam em luto antecipatório, sendo o atendimento psicoterapêutico realizado em setting domiciliar, na modalidade grupo. Para alcançar tal objetivo, utilizei como metodologia o estudo conceitual estrutural da Psicologia Analítica e dos constructos de Winnicott, com o intuito de buscar novas formas de intervenção psicoterápica em famílias que passam pela experiência de luto antecipatório.

Nessa direção, o primeiro passo da presente pesquisa foi a busca dos textos nos quais tanto Jung quanto os pós-junguianos trataram da questão do luto, sua relação com o processo de individuação, com a expressão simbólica individual, coletiva, no manejo clínico individual e em grupo. É importante destacar que alguns pós-junguianos foram visitados pelo fato de que trataram em suas obras sobre a questão do luto, e outros porque criaram uma clínica grupal, coerente aos fundamentos da Psicologia Analítica, aspectos importantes para a construção do resultado final da tese. A leitura dos textos de Jung e dos pós-junguianos gerou um quadro que serviu de guia para compreender o fenômeno do luto antecipatório e seu possível manejo junto ao público-alvo. Em seguida, foi realizada a procura de conceitos teóricos e da clínica de Winnicott, que serviriam para auxiliar a compreensão de alguns pontos úteis para a descrição do fenômeno, respeitadas as diferenças paradigmáticas entre Jung/Winnicott. Nesse caminho, alguns autores secundários também foram visitados para auxiliar na tarefa de compreensão dos conceitos selecionados, tanto para auxiliar na compreensão do fenômeno do luto antecipatório, quanto para contribuir com o manejo do fenômeno apontado.

Tendo como ponto de partida o processo de individuação e as questões relacionadas ao enfrentamento da morte e da compreensão de Winnicott acerca da noção de integração, de aniquilação do ser (e do self) e do desenvolvimento humano, apresento alguns pontos norteadores que podem ser utilizados neste tipo de atendimento. As reflexões aqui apresentadas poderão auxiliar no trabalho dos psicólogos e psicólogas domiciliares, oferecendo instrumentos e análises acerca do enfrentamento do período de luto anterior à morte, momento marcado por demandas relacionadas à dor psicológica e às transformações provocadas pela ameaça de morte de um ente querido. 
De modo geral, o atendimento do grupo familiar poderá ser um espaço de holding, ou seja, um vaso que contêm, aninha, embala, suporta a presença de defesas, tensões, regressões, polarizações, no esforço de integração da função transcendente e as diversas movimentações do processo de individuação. O grupo poderá trazer os familiares que estão desterrados, para a "terra matter" num sentido mais amplo, simbolicamente retornando para o próprio continente (individual), mas também regressando para o continente coletivo, para a tribo, clã, para seu grupo de pertencimento que, mesmo contendo inúmeras diferenças, diz respeito a sua história e a sua construção enquanto indivíduo ímpar e cidadão do mundo.

Para a Psicologia Analítica, o tratamento coletivo tem relação com as oposições humanas interpessoais e intrapessoais. Aqui são realizados processos sintéticos e simbólicos para produzir integração de um com os muitos, dos muitos com o uno. Nesse sentido o psicólogo ou a psicóloga têm a função no processo de elaboração, devendo estar atento aos processos verticais e horizontais, legitimando a necessidade de um espaço caloroso, realizando o holding suficientemente bom para que possa haver a integração do processo vida-morte-vida. O terapeuta analisará o material trazido pelo indivíduo no grupo, semelhante ao que acontece no atendimento individual, mas também dará espaço para a análise do grupo feita pelo grupo e para o próprio grupo.

Para encerrar este trabalho, trarei a imagem de La Loba, advinda de uma lenda mexicana que representa um princípio que poderá inspirar o trabalho dos psicólogos e psicólogas no que se refere à orientação do processo natural da vida-morte-vida, bem como sua ritualização simbólica. Não se pretende dizer que o profissional agirá como a protagonista dessa história, porque quem conhece a intimidade e as terras mais desérticas do paciente é ele próprio. La Loba vive dentro de cada um de nós, ela é aquela quem varre os desertos pacientemente, junta os ossos e traz vida.

Existe uma velha que vive num lugar oculto de que todos sabem, mas que poucos já viram. Como nos contos de fadas da Europa oriental, ela parece esperar que cheguem até ali pessoas que se perderam, que estão vagueando ou à procura de algo. Ela é circunspecta, quase sempre cabeluda e invariavelmente gorda, e demonstra especialmente querer evitar a maioria das pessoas. Ela sabe crocitar e cacarejar, apresentando geralmente mais sons animais do que humanos . . . O único trabalho de La Loba é o de recolher ossos. Sabe-se que ela recolhe e conserva especialmente o que corre o risco de se perder para o mundo. Sua caverna é cheia dos ossos de todos os tipos de criaturas do deserto: o veado, a cascavel, o corvo. Dizem, porém, que sua especialidade reside nos lobos. Ela se arrasta sorrateira e esquadrinha as montanhas e os arroyos, leitos secos de rios, à procura de ossos de lobos e, quando consegue reunir um esqueleto inteiro, quando o último osso está no lugar e a bela escultura branca da criatura está disposta à sua frente, ela senta junto ao fogo e pensa na canção que irá cantar. Quando se decide, ela se levanta e aproxima-se da criatura, ergue seus braços sobre o esqueleto e começa a cantar. É aí que os ossos das 
costelas e das pernas do lobo começam a se forrar de carne, e que a criatura começa a se cobrir de pelos. La Loba canta um pouco mais, e uma proporção maior da criatura ganha vida. Seu rabo forma uma curva para cima, forte e desgrenhado. La Loba canta mais, e a criatura-lobo começa a respirar. E La Loba ainda canta, com tanta intensidade que o chão do deserto estremece, e enquanto canta, o lobo abre os olhos, dá um salto e sai correndo pelo desfiladeiro. Em algum ponto da corrida, quer pela velocidade, por atravessar um rio respingando água, quer pela incidência de um raio de sol ou de luar sobre seu flanco, o lobo de repente é transformado numa mulher que ri e corre livre na direção do horizonte. Por isso, diz-se que, se você estiver perambulando pelo deserto, por volta do pôr-do-sol, e quem sabe esteja um pouco perdido, cansado, sem dúvida você tem sorte, porque $L a$ Loba pode simpatizar com você e lhe ensinar algo - algo da alma. (Estés, 2014, pp. 4142)

As lendas, bem como os conto de fadas, mitos e folclores, nos permitem acessar o inconsciente. Por isso, ao entrar em contato com este tipo de material, nos enchemos de um outro tipo de luz. Durante a vida perdemos parte de nós, durante a vida contemporânea perdemos parte da ligação básica, espiritual e subjetiva, com o grupo familiar. A ideia de La Loba está em possibilitar o trabalho de "busca dos ossos", isto é, daquilo que é essencial, estruturante. Ela é incansável, selvagem, não está a serviço das modernidades. Ela trabalha esquadrinhando os nossos desertos internos à procura de nossas partes que ficaram no caminho. Ela busca ossos! Os ossos trazem uma simbologia especial, relacionada a nossa estrutura enquanto animal. É aquilo que, mesmo com a ação inexorável da morte, se mantêm, como os arquétipos no inconsciente coletivo. Os ossos são metaforicamente eternos... e, para La Loba, eles podem, se reintegrados e ritualisticamente ressignificados, retomar a vida. Quando esta figura lendária canta, o chão do deserto estremece. Quando começamos a integrar nossas sombras no processo de individuação, algo é libertado e todo o entorno sente o chão tremer. Saímos da condição animal para a liberdade consciente, como o lobo que se transforma numa mulher que ri e corre livremente rumo ao próprio caminho, ao encontro com o si mesmo.

Dessa forma, para encerrar esta tese, devo dizer mais uma vez que o trabalho psicoterapêutico deve caminhar por esta seara. Além de promover espaços de acolhimento, fortalecimento dos laços de solidariedade e comunicação intrafamiliar, deve auxiliar também na orientação cognitiva, na legitimação do luto antecipatório e validação dos rituais de passagem. A partir de múltiplas fontes, esbocei o presente trabalho como um guia norteador, mas ainda há muito a ser feito no campo científico para ampliar tanto a compreensão dos processos que envolvem o luto antecipatório de familiares de pessoas acometidas por doenças crônico-degenerativas, quanto para a ampliação de ferramentas técnicas para o manejo adequado. 


\begin{abstract}
APÊNDICE
Seguem dois produtos técnicos que foram originados da presente tese: um destinado aos usuários da saúde e outro destinado aos profissionais de psicologia que trabalham na modalidade psicologia domiciliar. Tais produtos têm o objetivo de divulgar informações contidas nesta pesquisa, como a noção do que seja o processo de luto antecipatório vivido por familiares no contexto de doenças crônico-degenerativas, além de oferecer esclarecimentos e orientações técnicas. É importante dizer que, ao final de cada produto, existe uma pequena lista de referências e/ou sites composta por materiais relacionados ao assunto. Caso as pessoas se interessem em entender mais sobre o fenômeno e o manejo no contexto tratado na presente pesquisa, é possível acessar esses conteúdos pela internet. O formato em que foi construído possibilita a divulgação por meio das redes sociais (internet). A versão impressa pode ser disponibilizada em salas de espera de unidades de saúde públicas e/ou privadas, em formato de folhetos, cartazes etc.
\end{abstract}




\section{APÊNDICE A - Produto destinado aos usuários da saúde}

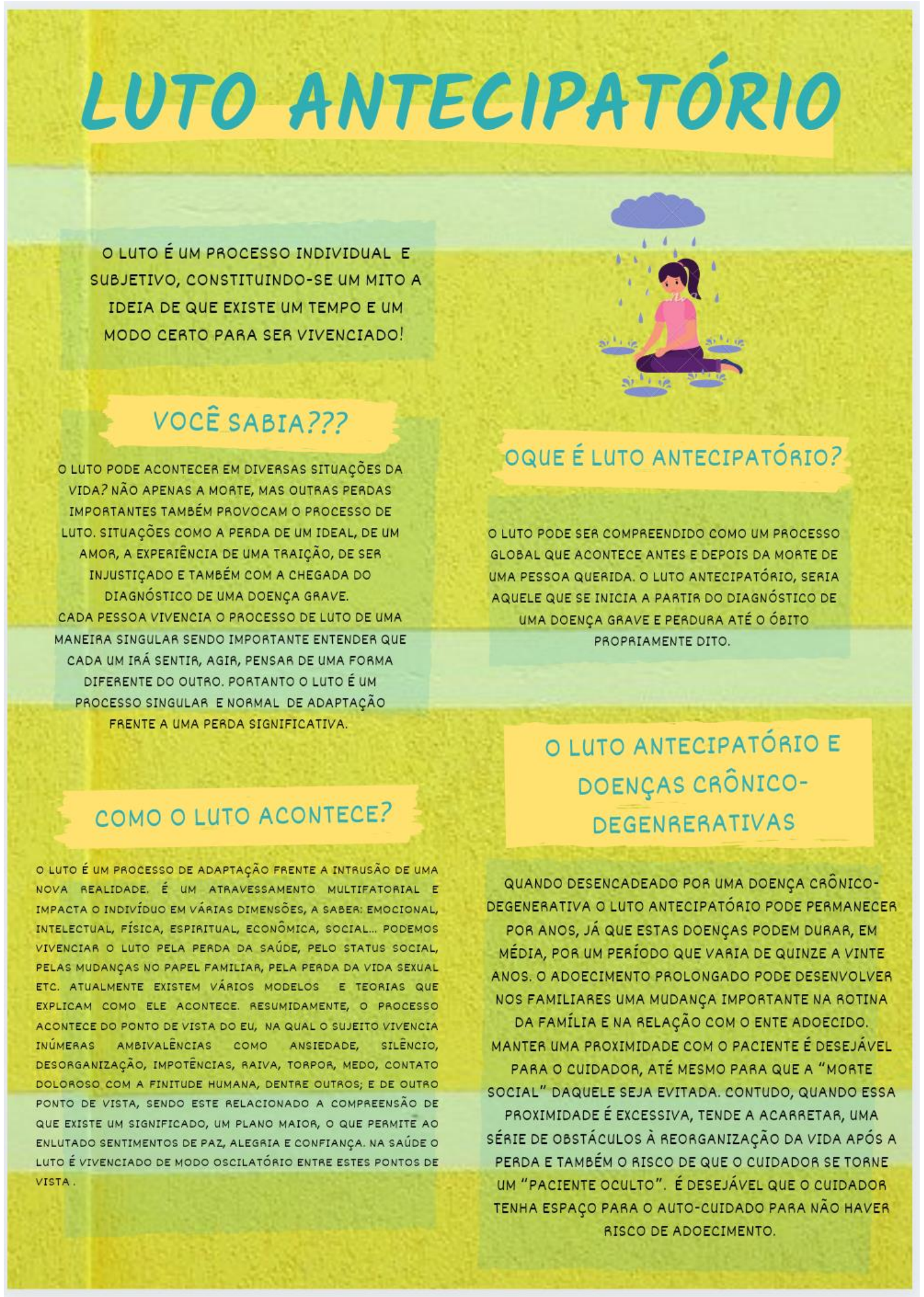

(Frente) 


\section{ATENÇÃo!!!}

- tema "morte" ainda é um grande tabu em nossa sociedade, com isso muitos assuntos são interditados e se cria o "pacto do silêncio" entre familiares e o ente adoecido, o que pode promover um gasto de energia e tempo enormes em ambas as partes.

Outro ponto importante é com relação aos riscos do luto complicado que compreende duas modalidades: crônico e inibido.

Luto crônico: é definido como aquele que se perpetua por muitos anos, provocando intenso sofrimento emocional por manter $o$ indivíduo excessivamente ligado a lembranças do ente que partiu, caracterizado pelo predomínio de sintomas como ansiedade, tensão, inquietação e insônia;

Luto inibido: tem como principal característica a negligência da vivência da perda. uma das características é o adiamento das reações de luto, conscientes ou inconscientes. Aqui o enlutado investe em atividades que não se relacionam com a perda, realizando predominantemente atividades que o fazem não entrar em

contato com a perda.
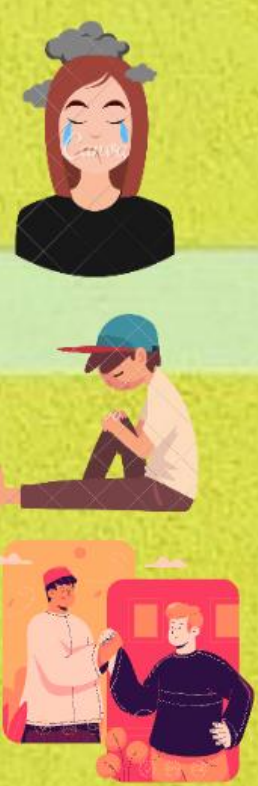

\section{O QUE SE DEVE FAZER?}

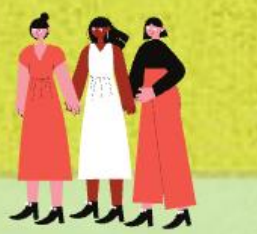

- compreenda que o luto antecipatório É um processo de adaptação normal, singular e SUbjetivo;

- acolha e legitime a dor de quem está sofrendo. não é hora de julgamentos, apenas escute suas HISTÓRIAS, SENTIMENTOS E SE NÃO CONSEGUIR MANTER ESTA ESCUTA, ENCAMINHE O ENLUTADO PARA OUTRA PESSOA QUE O POSSA ACOLHER;

- NÃo COMBATA A dOR PSICOLógICA COM PSICOFÁrMACOS, SEM INDICAÇÃo MÉdica. UM COPO d'ÁGUA E UM "ESTAR

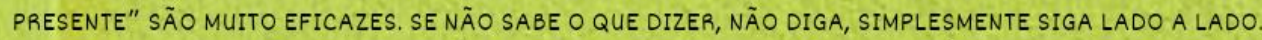

- tente desinterditar a comunicação, pergunte ao outro o que ele está sentindo, e tente dizer também SOBRE SEUS SENTIMENTOS E PENSAMENTOS. ISSO PODE AJUDAR A COLOCAR FIM AO PACTO DO SILÊNCIO;

- procure dividir as responsabilidades do cuidado entre os faMiliares. para cuidar de uMa pessoa ADOECIDA É PRECISO TER UM TEMPO PARA RECUPERAR AS FORÇAS E REALIZAR ATIVIDADES QUE TRAGAM PRAZER.

ESTE FOLHETO É UM DOS RESULTADOS DA PESQUISA DE DOUTORADO "ATUAÇÃO CLÍNICA JUNTO Á FAMILIARES EM LUTO ANTECIPATÓRIO EM CONTEXTO DOMICILIAR: UMA PROPOSTA A PARTIR DO PONTO DE VISTA DA PSICOLOGIA ANALITICA COM CONTRIBUIÇÕES DE WINNICOTT", DESENVOLVIDA NO PROGRAMA DE PÓS-GRADUAÇÃO NO DEPARTAMENTO DE PSICOLOGIA ESCOLAR E DESENVOLVIMENTO HUMANO DO INSTITUTO DE PSICOLOGIA DA UNIVERSIDADE DE SÃO PAULO, SOB A ORIETAÇÃO DO PROF. DR. LEOPOLDO FULGENCIO. ESTA PESQUISA TEM APOIO E FINANCIAMENTO DA CAPES.

REALIZAÇÃO E APOIO
LUDYMILLA ZACARIAS \&LEOPOLDO FULGENCIO
LUDYMILLAZ@YAHOO.COM.BR

(Verso) 


\section{APÊNDICE B - Produto técnico destinado aos psicólogos e psicólogas que trabalham na modalidade psicologia domiciliar}

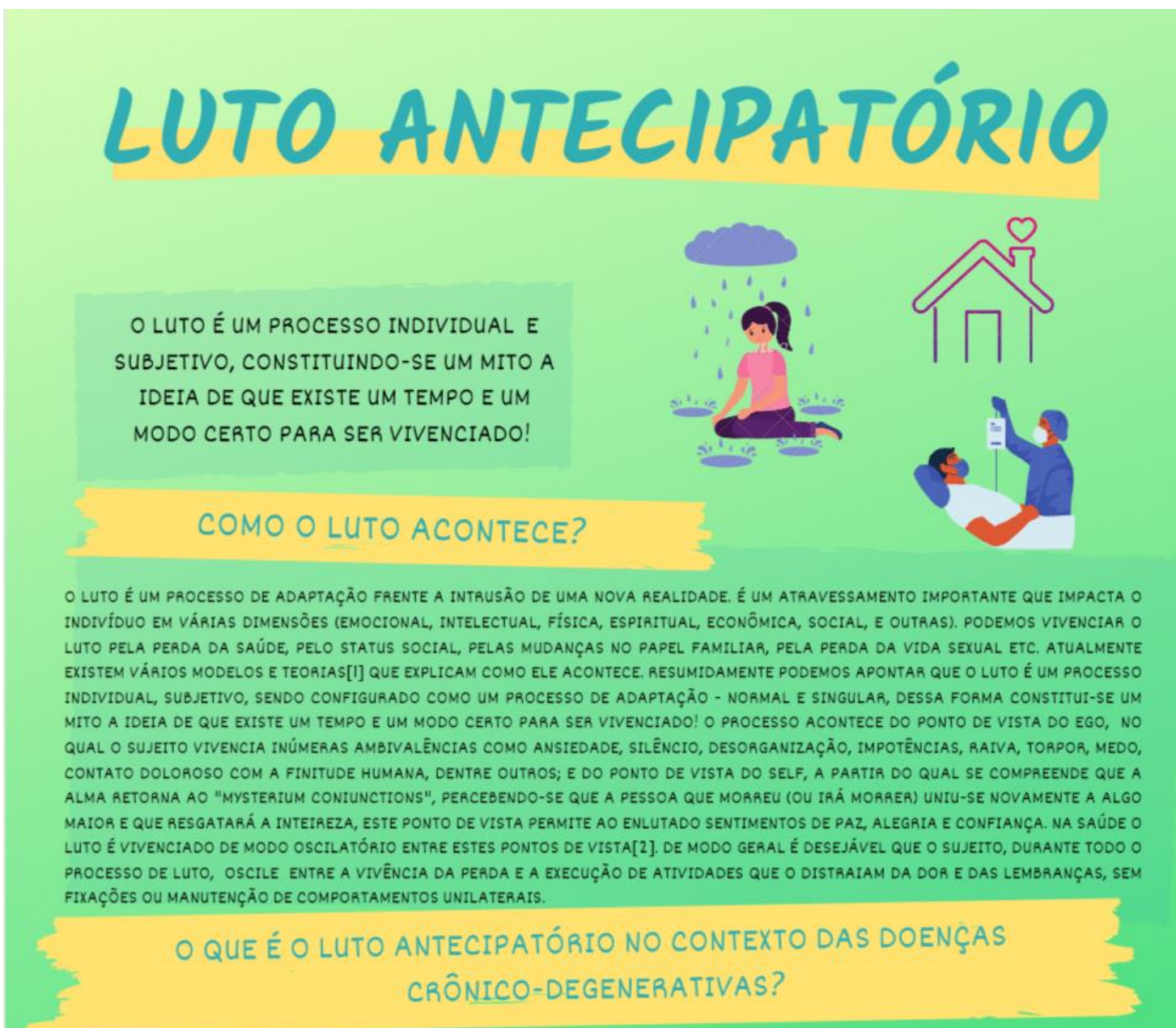

O LUTO PODE SER COMPREENDIDO COMO UM PROCESSO GLOBAL QUE ACONTECE ANTES E DEPOIS DA MORTE DE UMA PESSOA QUERIDA. O LUTO ANTECIPATÓrIO, SERIA AQUELE QUE SE INICIA A PARTIR DO DIAGNÓSTICO DE UMA DOENÇA GRAVE ("MORTE ANUNCIADA") E PERDURA ATÉ O ÓBITO PROPRIAMENTE DITO. QUANDO DESENCADEADO POR UMA DOENÇA CRÔNICO-DEGENERATIVA* O LUTO ANTECIPATÓRIO PODE PERMANECER POR ANOS, JÁ QUE ESTAS PODEM DURAR, EM MÉdIA, POR UM PERIODO QUE VARIA DE QUINZE A VINTE ANOS. O ADOECIMENTO PROLONGADO PODE DESENVOLVER NOS FAMILIARES UMA MUDANÇA IMPORTANTE NA ROTINA DA FAMILIA E NA RELAÇÃO COM O ENTE ADOECIDO. MANTER UMA PROXIMIDADE COM O PACIENTE É DESEJÁVEL PARA O CUIDADOR[3], ATÉ MESMO PARA QUE A "MORTE SOCIAL" DAQUELE SEJA EVITADA. CONTUDO, QUANDO ESSA PROXIMIDADE É EXCESSIVA, TENDE A ACARRETAR O RISCO DO CUIDADOR SE TORNAR UM "PACIENTE OCULTO" [M]E RISCOS DE QUE TER DIFICULDADES COM A REORGANIZAÇÃO DA VIDA APÓS A PERDA.

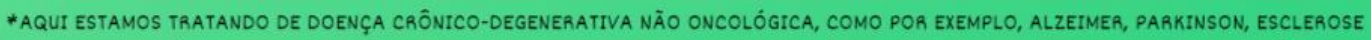
LATERAL AMIOTRÓFICA, ESCLEROSE MÚLTIPLA, ACIDENTE VASCULAR CEREBRAL, DENTRE OUTRAS QUE APRESENTAM SEQUELAS NEUROLÓGICAS E NEURO-MUSCULARES.

\section{FALANDO EM RISCOS....}

- TEMA "MORTE" AINDA É UM GRANDE TABU EM NOSSA SOCIEDADE, COM ISSO MUITOS ASSUNTOS SÃo INTERDITADOS E SE CRIA O "PACTO DO SILÊNCIO" ENTRE FAMILIARES E O ENTE ADOECIDO, O QUE PODE PROMOVER UM GASTO DE ENERGIA E TEMPO ENORMES EM AMBAS AS PARTES, TORNANDO O LUTO ANTECIPATÓRIO UM PROCESSO CANSATIVO, IMPRODUTIVO, COM DISTANCIAMENTO AFETIVO.

(Frente) 


\section{O QUE SE DEVE FAZER?}

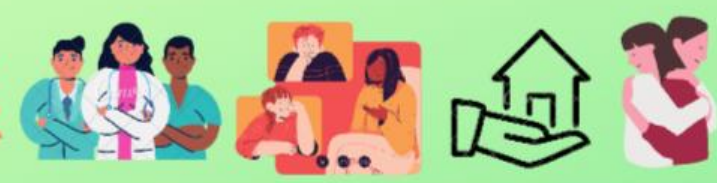

Muitos pesquisadores indicam que existem vários benefícios de suporte psicológico no processo de luto antecipatório já que este carrega um poder de ressignificação dos afetos e vínculos. sim, poderão existir várias questões (objetivas e subjetivas) para se tratar antes da morte do ente querido, e é papel dxs psicólogxs auxiliar na desinterdição da comunicação, respeitados os ritmos e ritos de cada familia, e mais, desenvolver um setting seguro para que as tensōes, histórias, sejam acolhidas.

compreendendo o luto antecipatório como um potente ritual de passagem, psicólogxs podem trabalhar com um manejo individual e/ou em grupo. No caso do trabalho em grupo é imprescindivel que haja uma busca ativa dos familiares para o cuidado em saúde mental e não somente o cuidador principal. Se couber atendimento em grupo este deverá acontecer em local e horário précombinados pelos interessados. Antes do início do atendimento em grupo é importante saber sobre a situação do paciente e a organização familiar na rotina do cuidado, sendo útil o levantamento de um diagnóstico situacional para compreender os recursos psicológicos e sociais da familia atendida.

É importante:

- $O$ atendimento psicológico deverá ter como objetivo o auxilio no processo de individuação de cada participante e também no suporte da ritualização familiar frente a passagem do processo vida-morte-vida tão presente no luto antecipatório;

- Desenvolver uma sustentação ambiental suficientemente boa, um continente que poderá promover um ambiente caloroso que acalenta, aquece, permite a transmutação sem queimar, e promove o encontro de oponentes "em volta da lareira" [5]. Este vaso alquímico deverá ser construído aos moldes do holding materno, para que o familiar possa se sentir seguro para tratar de suas questōes junto d familia. Isso não garante que tensões, espelhamentos malignos não ocorrerão, dessa forma o terapeuta deve estar atento d movimentação individual e grupal utilizando as técnicas e pilares referentes ao manejo do trabalho em grupo[6];

- Desenvolver uma escuta simbólica para os conteúdos que emergem, tanto do processo individual, quanto do coletivo familiar Teóricos da Psicologia Analítica orientam que os seres humanos precisam de balizadores para conseguir lidar com a inexorável presença da morte, já que a razão não consegue dar conta desta demanda. os balizadores seriam os conteúdos que emergem do inconsciente pessoal e coletivo, em sonhos, no uso de material expressivo (pintura, escultura etc), conto de fadas, mitos dentre outros.

\section{LITERATURAS QUE PODEM AJUDAR}

1 GONZAGA, L. Z M. (2012) MORTES ANUNCTADAS: IMPLICAÇŌES PARA O LUTO DO CUIDADORES FAMILIARES. (MESTRADO MASTEA'S DEGREE), UNIVEASTDADE FEDERAL DE UBERLÂNDIA, UBERLÂNDIA.

2.JUNG, C. G. (2006). MEMÓ́RIAS, SONHOS E REFLEXÕES. ATO DE JANETRO: NOVA FRONTEIRA.

3.KOVÁCS, M. L. (2014). A CAMTNHO DA MORTE COM DIGNIDADE NO SÉCULO XX: AEVISTA BIOÉTICA, 22(1), 94-104

4. COUTO, C. B. (2004). O PACTENTE OCULTO: REVELANDO AS CONSEQUÊNCIAS QUE O CUIDAR DE UM PACIENTE PORTADOR DE ESCLEROSE LATERAL AMTOTRÓFICA PROMOVE NA VIDA DO CUIDADOR FAMILIAR. (TESE DE DOUTORADO), UNIVERSIDADE FEDERAL DO RIO DE JANEIAO, RIO DE JANEIRO.

5. FAEITAS, $L V$. (2005). GAUPOS VIVENCTAIS SOB A PEASPECTIVA JUNGUTANA PSICOLOGIA USP, 16 (3), $45-69$.

6.L ZINKIN. (1998). DIALOGUE IN THE ANALYTIC SETTING LONDON AND PHILADELHIA JESSICA KINGSLAY PUBLISHER.

E MAIS.

FAANCO, M. H. P. (2002). ESTUdOS AVANÇADOS SOBAE O LUTO. CAMPINAS: O LIVRO PLENO.

KOVÁCS, M. J. (1992). MOATE E DESENVOLVIMENTO HUMANO SÃO PAULO: CASA DO PSICÓLOGO.

PARKES, C. M. (1998). LUTO: ESTUDOS SOBRE A PEADA NA VIDA ADULTA (M. H. P. FAANCO, TRANS., SÃO PAULO: SUMMUS.

LAHAM, C. F. (2004) PECULIAAIDADES DO ATENDIMENTO PSICOLÓGICO EM DOMICfLIO E O TRABALHO EM EQUTPE, PSICOLOGIA HOSPITALAR, 2(2), 0-0

FONSECA, L. P. \& FONSECA, M. I. I. (2002). LUTO ANTECTPATÓRIO. IN M. H. P. F. (ORG.) (EO.), ESTUDOS AVANÇADOS SOBRE O LUTO (PP. 69-91). CAMPINAS: LIVRO PLENO.

AANDO, T. A. (1986). LOSS AND ANTICIPATORY GRIEF. UNITED STATES OF AMERICA: D.C. HEATH AND COMPANY.

\section{REALIZAÇÃO E APOIO}

ESTE FOLHETO É UM DOS RESULTADOS DA PESQUISA DE DOUTORADO "ATUAÇÃO CLÍNICA JUNTO À FAMILIARES EM LUTO ANTECIPATÓRIO EM CONTEXTO DOMICILIAR: UMA PROPOSTA A PARTIR DO PONTO DE VISTA DA PSICOLOGIA ANALITICA COM CONTRIBUIÇÕES DE WINNICOTT", DESENVOLVIDA NO PROGRAMA DE PÓS-GRADUAÇÃO NO DEPARTAMENTO DE PSICOLOGIA ESCOLAR E DESENVOLVIMENTO HUMANO DO INSTITUTO DE PSICOLOGIA DA UNIVERSIDADE DE SÃO PAULO, SOB A ORIETAÇÃO DO PROF. DR. LEOPOLDO FULGENCIO. ESTA PESQUISA TEM APOIO E FINANCIAMENTO DA CAPES.

$$
\text { REALIZAÇÃO E APOIO }
$$

LUDYMILLA ZACARIAS \& LEOPOLDO FULGENCIO LUDYMILLAZ@YAHOO.COM.BR
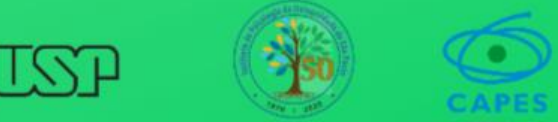

(Verso) 


\section{REFERÊNCIAS ${ }^{22}$}

Abram, J. (1996). The Language of Winnicott. A dictionary of Winnicott's Use of Words. London: Karnac Books.

Abram, J. (2000). A Linguagem de Winnicott. Rio de Janeiro: Revinter, 2000.

Abram, J. (2007). The Language of Winnicott. A dictionary of Winnicott's Use of Words (2 ed.). London: Karnac Books.

Abram, J. (2008). Donald Woods Winnicott (1896-1971): A brief introduction. The International Journal of Psychoanalysis, 89(6), 1189-1217.

Amorin, S. F. (2004). Intervenção psicológica no hospital geral. In A prática da psicologia hospitalar na Santa Casa de São Paulo: novas páginas em uma antiga história (pp. 69-80). São Paulo: Casa do Psicólogo.

Antoniazzi, A. S., Dell'aglio, D. D., \& Bandeira, D. R. (1998). O conceito de coping: uma revisão teórica. Estudos de Psicologia, 3(2), 273-294.

Arantes, A. C. Q. (2013). Luto antecipatório: avaliação, diagnósticoc e conduta. Paper presented at the XII Congresso Interdisciplinar de Assistência Domiciliar, São Paulo.

Ariès, P. (1981). A história da morte no Ocidente Rio de Janeiro: Francisco Alves.

Barreto, M. L., \& Carmo, E. H. (1995). Mudanças em padrões de morbimortalidade: conceitos e métodos. In Velhos e novos males da saúde no Brasil: a evolução do país e de suas doenças (pp. 17-30). São Paulo: Hucitec.

Batistelli, F. M. V. (2010). Caminhos na elaboração de um luto. Jornal de Psicanálise, $43,155-162$.

Boechat, P. P. (2011). Terapia Familiar: mitos, símbolos e arquétipos. Rio de Janeiro: Wak editora.

Bolen, J. S. (1990). As Deusas e a Mulher: nova psicologia das mulheres. São Paulo: Paulus.

Bowlby, J. (1973). Apego e Perda (Vol. 2 - Separação: angústia e raiva). São Paulo: Martins Fontes.

Bowlby, J. (1990). Apego e perda: separação, angústia e raiva. São Paulo: Martins Fontes.

\footnotetext{
${ }^{22}$ De acordo com o estilo American Psychological Association (APA) 6a edição.
} 
Brasil. (1999). Política Nacional de Saúde do Idoso. Portaria $n^{\circ} 1.395$, de 9 de dezembro de 1999. Brasília: Ministério da Saúde.

Brasil, M. d. S. (2004). HumanizaSUS prontuário transdisciplinar e projeto terapêutico. Textos básicos de saúde. Acesso em 14/05/2017.

Bromberg, M. H. P. F. (1997). A psicoterapia em situações de perdas e luto. CampinasSP: Editorial Psy.

Byington, C. A. B. (2005). A imaginação ativa com o morto na elaboração do luto patológico. In Reflexões sobre a morte no Brasil. São Paulo: Paulus.

Callia, M. H. P. (2005). Apresentando a morte. In Reflexões sobre a morte no Brasil. São Paulo: Paulus.

Campbell, J. (2007). O herói de mil faces. São Paulo: Cultrix/Pensamento.

Caponero, R., \& Bifulco, V. A. (2018). Cuidados paliativos: um olhar sobre as práticas e necessidades atuais. Barueri-SP: Manole.

Caponero, R., \& V.A., B. (2016). Cuidados Paliativos - Conversas sobre a vida e a morte na saúde São Paulo: Editora Manole.

Carr, D. (2010). New perspectives on the Dual Process Model (DPM). Omega, 61(4), 371-380.

Catta-Preta, M. (2012). Análise de série de sonhos de paciente insone em psicoterapia individual. In A noita da alma: sonhos e insônia. São Paulo: Vetor.

Cobliner, W. G. (1965). A escola de psicologia genética de Genebra e a psicanálise: paralelos e equivalências In R. A. Spitz (Ed.), O primeiro ano de vida. São Paulo: Martins Fontes.

Coelho, M. M. (2005). Melancolia, poesia e morte. In Reflexões sobre a morte no Brasil. São Paulo: Paulus.

Couto, C. B. (2004). O paciente oculto: revelando as consequências que o cuidar de um paciente portador de esclerose lateral amiotrófica promove na vida do cuidador familiar. (Tese de Doutorado), Universidade Federal do Rio de Janeiro, Rio de Janeiro.

CRP-SP (2017), Orientação para atendimento domiciliar. Acesso em 16/05/2017.

Dalbem, J. X., \& Dell'Aglio, D. D. (2005). Teoria do apego: bases conceituais e desenvolvimento dos modelos internos de funcionamento. Arquivos Brasileiros de Psicologia, 57(1), 12-24.

Delalibera, M. A. (2010). Adaptação e validação portuguesa do Instrumento de Avaliação do Luto Prolongado - Prolonged Grief Disorder (PG-13). (Mestrado), Universidade de Lisboa, Lisboa. 
Dias, E. O. (2003). A teoria do amadurecimento de D. W. Winnicott. Rio de Janeiro: Imago Editora.

Duarte, I. V., Fernandes, K. F., \& Freitas, S. C. d. (2013). Cuidados Paliativos Domiciliares: considerações sobre o papel do cuidador familiar. Revista Sociedade Brasileira de Psicologia Hospitalar, 16(2), 73-88.

Estés, C. P. (2014). Mulheres que correm com os lobos: mitos e histórias do arquétipo da mulher selvagem. Rio de Janeiro: Rocco.

Ettin, M. F. (1995). The spirit of junguian group psychotherapy: from taboo to totem. . International journal of group psychotherapy, 45(4), 449-467.

Fiorini, H. J. (1981). Teoria e técnica de psicoterapias. Rio de Janeiro: Francisco Alves.

Flach, K., Lobo, B. d. O. M., Potter, J. R., \& Lima, N. S. (2012). O luto antecipatório na unidade de terapia intensiva pediátrica: relato de experiência. Revista Sociedade Brasileira de Psicologia Hospitalar, 15(1).

Fonseca, J. P. (2004). Luto Antecipatório. Campinas: Editora Livro Pleno.

Fonseca, J. P., \& Fonseca, M. I. I. (2002). Luto antecipatório. In M. H. P. F. (Org.) (Ed.), Estudos avançados sobre o luto (pp. 69-91). Campinas: Livro Pleno.

Fordham, M. (1994). A criança como indivíduo. São Paulo: Cultrix.

Franco, M. H. P. (2002). Uma mudança no paradigma sobre o enfoque da morte e do luto na contemporaneidade. In Estudos avançados sobre o luto (pp. 15-38). Campinas: Livro Pleno.

Franco, M. H. P. (2018). Cuidados paliativos e vivência de luto. In Cuidados paliativos: um olhar sobre as práticas e as necessidades atuais. Barueri: Manole.

Freitas, L. V. (1990). O Arquetipo do Mestre-Aprendiz - considerações sobre a vivência. Revista Junguiana, 8, 72-99.

Freitas, L. V. (2005). Grupos vivenciais sob a perspectiva junguiana. Psicologia USP, 16(3), 45-69.

Freud, S. (1917e). Luto e melancolia. In Edição Standard Brasileira das obras psicológicas de Sigmund Freud (Vol. 14, pp. 245-266). Rio de Janeiro: Imago.

Fulgencio, L. (2013). Metodologia de pesquisa em psicanálise na universidade. In F. Scorsolini-Comin \& C. A. Serralha (Eds.), Psicanálise e Universidade: Um encontro na pesquisa (pp. 27-67). Curitiba: CRV.

Fulgencio, L. (2014). A necessidade de ser como fundamento do modelo ontológico do homem para Winnicott. In A fabricação do humano (pp. 145-159). São Paulo: Zagodoni. 
Fulgencio, L. (2015). Apontamentos para uma análise da influência do existencialismo moderno na obra de Winnicott. Ciência e Cultura, 67(1), 36-39.

Fulgencio, L. (2016). Por que Winnicott? São Paulo: Zagodoni.

Fulgencio, L. (2017). A Psicanálise de Winnicott como uma teoria do desenvolvimento socioemocional do ser. (Livre Docência), Universidade de São Paulo, São Paulo.

Fulgencio, L. (2019). Winnicott and the Development of Being: youtube: https://www.youtube.com/watch?v=diC9ETMYC7k\&t=112s.

Fulgencio, L. (2020a). Incommensurability between paradigms, revolutions and common ground in the development of psychoanalysis. The International Journal of Psychoanalysis, 101(01), 13-41. doi:10.1080/00207578.2019.1686389.

Fulgencio, L. (2020b). Psicanálise do Ser - A Teoria Winnicottiana do Desenvolvimento Emocional como uma Psicologia de Base Fenomenológica. São Paulo: EDUSPFAPESP.

Fulton, R., \& Gottesnan, D. J. (1980). Anticipatory grief: a psycohosocial concept reconsidered. British Journal of Psychiatry, 137, 45-54.

Galheigo, M. S. (1999). A transdisciplinaridade enquanto princípio e realidade das ações de saúde. Rev Terap Ocupac, 10(2-3).

Gambini, R. (2005). A morte como companheira. In Reflexões sobre a morte no Brasil (pp. 135-146). São Paulo: Paulus.

Gonzaga, L. Z. M. (2012). Mortes anunciadas: implicações para o luto dos cuidadores familiares. (mestrado), Universidade Federal de Uberlândia, Uberlândia.

Gonzaga, L. Z. M. (2015). As Moiras e a Tecelã: mulheres que fiam o luto. Saarbrücken: Novas Edições Acadêmicas (OmniScriptum GmbH \& Co. KG).

Henderson, J. L. (2008). Os mitos antigos e o homem moderno. In O homem e seus símbolos. Rio de Janeiro: Nova Fronteira.

Hillman, J. (1997). O código do ser: uma busca do caráter e da vocação pessoal. Rio de Janeiro: Objetiva.

Hillman, J., \& Shamdasani, S. (2015). Lamento dos Mortos: a psicologia depois do O Livro Vermelho de Jung. Petrópolis: Vozes.

Hollis, J. (2015). A passagem do meio: da miséria ao significado da meia-idade. São Paulo: Paulus.

Jacoby, M. (2011). O encontro analítico: transferência e relacionamento humano. Petrópolis: Vozes. 
Jaffé, A. (1980). A visão de C. G. Jung sobre a morte. In A morte à luz da Psicologia. São Paulo: Cultrix.

Johnson, R. A. (1993). He: a chave do entendimento da Psicologia Masculina. São Paulo: Mercuryo.

Jung, C. G. (2001). Cartas I. Petrópolis: Vozes.

Jung, C. G. (2002). A energia psíquica. In C. G. Jung Obras Completas (Vol. 8/1, pp. 99). Petrópolis: Vozes.

Jung, C. G. (2003). Cartas III. Petrópolis: Vozes.

Jung, C. G. (2006). Memórias, Sonhos e Reflexões. Rio de Janeiro: Nova Fronteira.

Jung, C. G. (2007). Prólogo aos "Estudos sobre a Psicologia de C.G. Jung” de Toni Wolff. In Obra Completa C. G. Jung (Vol. 10/3, pp. 216-222). Petrópolis: Vozes.

Jung, C. G. (2008). O homem e seus símbolos. Rio de Janeiro: Nova Fronteira.

Jung, C. G. (2013a). A prática da psicoterapia. In Obras Completas C. G. Jung (Vol. 16/1). Petrópolis: Vozes.

Jung, C. G. (2013c). A Natureza da Psique. In Obras Completas C. G. Jung (Vol. 8/2). Petrópolis: Vozes.

Jung, C. G. (2013d). O desenvolvimento da personalidade In Obras Completas C. G. Jung (Vol. 17). Petrópolis: Vozes.

Jung, C. G. (2013e). O eu e o inconsciente. In Obras Completas C. G. Jung (Vol. 7/2). Petrópolis: Editora Vozes.

Jung, C. G. (2013f). Psicologia do Inconsciente In Obras Completas C. G. Jung (Vol. 7/1). Petrópolis: Editora Vozes.

Jung, C. G. (2013g). Símbolos da Transformação. In Obras Completas C. G. Jung (Vol. 5). Petrópolis: Vozes.

Jung, C. G. (2013h). Os arquétipos e o inconsciente coletivo In Obras Completas C. G. Jung (Vol. 9/1). Petrópolis: Editora Vozes.

Jung, C. G. (2013i). A energia psíquica. In Obras Completas C. G. Jung (Vol. 8/1). Petrópolis: Vozes.

Jung, C. G. (2013j). Tipos Psicológicos. In Obras Completas C. G. Jung (Vol. 6). Petrópolis: Vozes.

Jung, C. G. (2013k). Ab-reação, análise dos sonhos e transferência. In C. G. Jung Obras Completas (Vol. 16/2). Petrópolis: Vozes. 
Jung, C. G. (20131). A alma e a morte. In Obras Completas C. G. Jung (Vol. 8/2, pp. 361372): Petrópolis.

Jung, C. G. (2013m). Aspectos do drama contemporâneo. In Obras Completas de C.G. Jung (Vol. 10/2). Petrópolis: Vozes.

Júnior, F. d. A. (2009). O Desenvolviemnto da capacidade de ter fé. Um estudo do ponto de vista da psicanálsie de D. W. Winnicott. (Mestrado), Pontifícia Universidade Católica, Campinas.

Junior, V. P. (2008). A atenção domiciliar e o psicólogo: experiências, apontamentos para a formação e indícios para uma clínica. (Mestrado), Universidade Federal de São Paulo, São Paulo.

Kovács, M. J. (1992). Morte e desenvolvimento humano São Paulo: Casa do Psicólogo.

Kovács, M. J. (2003a). Comunicação nos programas de cuidados paliativos: uma abordagem multidisciplinar Mundo Saúde, 27(1), 71-80.

Kovács, M. J. (2003b). Educação para a morte. Temas e reflexões. São Paulo: Casa do Psicólogo.

Kovács, M. J. (2008). Desenvolvimento da Tanatologia: estudos sobre a morte e o morrer. Paidéia, 18(41), 457-468.

Kovács, M. J. (2014). A caminho da morte com dignidade no século XXI. Revista Bioética, 22(1), 94-104.

Kreuz, G., \& Franco, M. H. P. (2017). O luto do idoso diante das perdas da doença e do envelhecimento. Arquivos Brasileiros de Psicologia, 69(2), 168-186.

Kübler-Ross, E. (1996). Morte: estágio final da evolução. Rio de Janeiro: Nova Era.

Kübler-Ross, E. (1998a). A Roda da Vida: Sextante.

Kübler-Ross, E. (1998b). Sobre a morte e o morrer São Paulo: Martins Fontes.

Kuhn, T. S. (1970). A estrutura das revoluções científicas. São Paulo: Perspectiva, 1975.

Laham, C. F. (2004). Peculiaridades do atendimento psicológico em domicílio e o trabalho em equipe. Psicologia Hospitalar, 2(2).

Langaro, F. ( 2017). "Salva o Velho!": Relato de Atendimento em Psicologia. Psicologia: Ciência e Profissão, 37(n¹), 224-235. doi:https://doi.org/10.1590/1982$\underline{3703000972014 .}$

Lebow, G. H. (1976). Facilitating adaptation in anticipatory mourning. Social casework, $57,458-466$. 
Lindemann, E. (1944). Symptomatology and management of acute grief. American Journal of Psychiatry, 101(2), 141-148.

Loparic, Z. (2014). Temporalidade e regressão. Paper presented at the Tempo do amadurecimento In II Congresso Winnicott Luso-Brasileiro: A retomada do amadurecimento, Lisboa.

Magalhães, S. d. S., \& Serbena, C. A. (2011). Morte, sonhos e individuação. Junguiana Revista Latino-Americana da Sociedade Brasileira de Psicologia Analitica, 29(1), 5-13.

Matheson, C. M., \& Tinsley, R. (2016). The carnivalesque and event evolution: a study of the Beltane Fire Festival. Leisure Studies, 35, 1-27.

Matsumoto, D. Y. (2012). Cuidados Paliativos: conceito, fundamentos e princípios. In R. T. d. Carvalho \& H. A. Parsons (Eds.), Manual de Cuidados Paliativos ANCP: ampliado e atualizado ( $2^{\mathrm{a}}$ edição ed.): Academia Nacional de Cuidados Paliativos

Mazorra, L. (2009). A construção de significados atribuídos à morte de um ente querido e o processo de luto. (Doutorado), Pontifícia Universidade Católica de São Paulo, São Paulo.

Melo, L. N. P., \& Saintrain, M. V. d. L. (2009). Perfil epidemiológico de mulheres idosas atendidas no "grupo de apoio à prevenção da incapacidade funcional". Revista Brasileira em Promoção da Saúde, 22(4), 251-258.

Menezes, R. A. (2004). Em busca da boa morte: antropologia dos cuidados paliativos Rio de Janeiro: Garamond.

Morin, E. (2000). A cabeça bem feita: repensar a reforma. Reformar o pensamento. Rio de Janeiro: Bertrand Brasil.

Neumann, E. (1995). A criança: estrutura e dinâmica da personalidade em desenvolvimento desde o início de sua formação. São Paulo: Cultrix.

Neumann, E. (2014 ). A História da Origem da Consciência. São Paulo: Cultrix.

Oliveira, M. F. d. (2005). Os sonhos e a morte na vida de Jung. In Reflexões sobre a morte no Brasil. São Paulo: Paulus.

Oliveira, M. F. d., \& Callia, M. H. P. (2005). Reflexões sobre a morte no Brasil. São Paulo: Paulus.

Paliativos, A. N. d. C. (2009). Manual de cuidados paliativos. Rio de Janeiro: Diagraphic Editora.

Parisi, S. (2009). Separação amorosa e individuação feminina: uma abordagem em grupo de mulheres no enfoque da Psicologia Analítica (Doutorado), Universidade de São Paulo, São Paulo. 
Parkes, C. M. (1998). Luto: estudos sobre a perda na vida adulta (M. H. P. Franco, Trans.). São Paulo: Summus.

Parkes, C. M. (2001). A historical overview of the cientific study of bereavement. In Handbook of bereavement research: consequences, coping and care (pp. 25-45). Washington American Psychological Association.

Parkes, C. M. (2009). Amor e perda: as raízes do luto e suas complicações. São Paulo: Summus.

Penna, E. M. D. (2004). O paradigma junguiano no contexto da metodologia qualitativa de pesquisa. Psicologia USP, 16(3), 71-94.

Penna, E. M. D. (2014). As mensagens dos sonhos: traduzir e compreender processamento simbólico arquetípico. In Sonhos na psicologia junguiana. São Paulo: Paulus.

Phillips, A. (2007). Winnicott. São Paulo Idéias \& Letras.

Pincus, L. (1989). A família e a Morte: como enfrentar o luto. Rio de Janeiro: Paz e Terra.

Pine, V. R. (1986). An agenda for adaptative antecipation for bereavement. In Loss and anticipatory grief. United States of America: DC Heath and Company.

Pinheiro, R. K. (2011). Viviane e Morgana: uma nova dicotomia em meio à tensão discursiva de As Brumas de Avalon. (doutorado), Universidade Católica de Pelotas, Pelotas.

Popper, K. R. (1957). La science: conjectures et réfutations. In Popper. Paris: Payot.

Rando, T. A. (1983). An investigation of grief and adaptation in parents whose children have died from cancer. Journal of Pediatric Psychology, 8, 3-20.

Rando, T. A. (1986). Loss and anticipatory grief. United States of America: D.C. Heath and Company.

Rando, T. A. (1993). The increasing prevalence of complicated mourning: The onslaught is just beginning. Omega: Journal of Death and Dying, 26, 43-59.

Rando, T. A. (2000). Clinical Dimensions of Antecipatory Mourning: Theory and Practice in Working with the Dying, their loved one's and their caregivers Champain: Research Press.

Rodrigues, S. R. (2009). O corpo deficiente e individuação: um olhar sobre a pessoa com deficiência física a partir da psicoterapia breve de orientação junguiana. (mestrado), Universidade de São Paulo, São Paulo.

Rolland, J. (1995). Doença Crônica e o Ciclo de Vida Familiar In As mudanças no Ciclo de Vida Familiar. Porto Alegre: Artes Médicas. 
Rolland, J. S. (1990). Anticipatory Loss: A Family Systems Developmental Fam Proc 29, 229-244.

Rottenstein, A. (2005). O sentido da vida e da morte através dos tempos. In Biotanatologia e bioética (pp. 37-48). Belo Horizonte: Paulinas.

Roussillon, R. (2009). Transitionnel et réflexivité. Les Lettres de La Société de Psychanalyse Freudiene, Winnicott, un psychanalyste dans notre temps(21), 123140.

Sá, L. C. M. d. (2011). O simbolismo da morte na mitologia indígena brasileira: uma abordagem junguiana. (Mestrado), PUC, São Paulo.

Samuels, A. (1989). Jung e os pós-junguianos. Rio de Janeiro: Imago.

Samuels, A., Shorter, B., \& Plaut, F. (1998). Dicionário Crítico de Análise Junguiana. Rio de Janeiro: Imago.

Saúde, M. d. (2010). O que é clínica ampliada. Cartilhas.

Saúde, M. S. (2009). Clínica ampliada e compartilhada. Brasília: Ministério da Saúde.

Saúde, S. U. (2016). Portaria $N^{o} 825$, de 25 de abril de 2016 Brasília: Ministério da Saúde.

Saunders, C. (1990). Hospice and palliative care: an interdisciplinary approach Londres: Edward Arnald.

Savage, J. A. (1989). Vidas não vividas: o sentido psicológico da perda simbólica e da perda real na morte de um filho. São Paulo: Cultrix.

Selye, H. (1965). The stress of life. New York: McGraw-Hill.

Silva, M. D. F. S. (2004). Processos de luto e educação. (Mestrado), Universidade do Minho, Braga.

Silveira, N. d. (1981). Jung: vida e obra. Rio de Janeiro: Paz e Terra.

Silveira, N. d. (1992). O mundo das imagens. São Paulo: Ática.

Silveira, N. d. (2018). Imagens do inconsciente. Petrópolis: Editora Vozes.

Soares, A. d. A. (2002). Worecü: a simbologia do ritual no corpo da mulher Tikuna. Paper presented at the Actas do VI Congresso Luso-Afro-Brasileiro de Ciências Sociais. As Ciências Sociais nos Espaços de Lıngua Portuguesa, balanços e desafios.

Spelman, M. B. (2013a). The Evolution of Winnicott's Thinking: Examining the Growth of Psychoanalytic Thought Over Three Generations. London: Karnac Books. 
Spelman, M. B. (2013b). Winnicott's Babies and Winnicott's Patients: Psychoanalysis as Transitional Space London: Karnac Books.

Stroebe, M., Hansson, R. O., Stroebe, W., \& Schut, H. (2001). Handbook of Berevement Research - Consequences, Coping and Care. Washington DC: American Psychological Association.

Stroebe, M., \& Schut, H. (1999). The dual process model of bereavement: rationale and description. Death Studies, 23, 197-224.

Stroebe, M., Schut, H., \& Boerner, K. (2017). Cautioning health-care professionals: bereaved persons are misguided through the stages of grief Omega, 74(4), 455473. doi:10.1177/0030222817691870.

Testa, A. L., \& Serbena, C. A. (2019). Psicoterapia de grupos e Psicologia Analítica. Revista Brasileira de Psicoterapia, 21(2), 59-77.

Torres, W. C. (1998). A criança diante da morte: desafios São Paulo: Casa do Psicólogo.

Urrutigaray, M. C. (2011). Arteterapia a transformação pessoal pelas imagens. Rio de Janeiro: WAK.

Vasconcellos, E. A., \& Giglio, J. S. (2007). Introdução da arte na psicoterapia: enfoque clínico e hospitalar. Estudos de Psicologia, 24 (3), 375-383.

Velano, M., \& Azambuja, E. (2020). Conexão Lisboa: O projeto Santinho, por um trabalho de luto coletivo. Acesso em 31/10/2020.

Vilhena, M. A. F. (2009). O desenvolvimento da personalidade e o processo de individuação: a visão de Jung e de pós-junguianos considerações sobre a infância. Albertini, P. \& Freitas, L. (orgs.). Jung e Reich: articulando teorias e práticas (pp. 32-49). Rio de Janeiro: Editora Guanabara.

von Franz, M.-L. (1980). Adivinhação e sincronicidade: a psicologia da probablidade significativa. São Paulo: Cultrix.

von Franz, M.-L. (1990). A interpretação dos contos de fadas. São Paulo: Paulus.

von Franz, M.-L. (1995). Os sonhos e a morte: uma interpretação junguiana. São Paulo Cultrix.

von Franz, M.-L. (2008). O processo de individuação. In O homem e seus símbolos (pp. 207-308). Rio de Janeiro: Nova Fronteira.

von Franz, M. L. (2010). O feminino nos contos de fadas. Petrópolis: Vozes.

Wahba, L. L. (2005a). Eu e tu: quando o tu desaparece. In Reflexões sobre a morte no Brasil. São Paulo: Paulus. 
Wahba, L. L. (2005b). Eu e Tu: quando o Tu desaparece. In Reflexões sobre a morte no Brasil (pp. 175-184). São Paulo: Paulus.

Whitmont, E. (1974). Analysis in a group setting. Quadrant, 16, 5-25.

Whitmont, E. C. (1991). Retorno da Deusa. São Paulo: Summus.

Whitmont, E. C. (1995). A busca do símbolo: conceitos básicos de Psicologia Analítica. São Paulo: Cultrix.

Winnicott, C. (1989). D.W.W.: Uma Reflexão. In Explorações Psicanalíticas: D. W. Winnicott (pp. 1-13). Porto Alegre: Artes Médicas, 1994.

Winnicott, D. W. (1945h). Para um Estudo Objetivo da Natureza Humana. In Pensando sobre Crianças (pp. 31-37). Porto Alegre: Artes Médicas, 1997.

Winnicott, D. W. (1955d). Aspectos Clínicos e Metapsicológicos da Regressão no Contexto Psicanalítico. In Da Pediatria à Psicanálise: Obras Escolhidas (pp. 374-392). Rio de Janeiro: Imago Ed., 2000.

Winnicott, D. W. (1957o). A Contribuição da Mãe para a Sociedade. In Tudo Começa em Casa (pp. 117-122). São Paulo: Martins Fontes, 1999.

Winnicott, D. W. (1958d). Ansiedade Associada à Insegurança. In Da Pediatria à Psicanálise: Obras Escolhidas (pp. 163-167). Rio de Janeiro: Imago Ed., 2000.

Winnicott, D. W. (1958f). Memórias do Nascimento, Trauma do Nascimento e Ansiedade. In Da Pediatria à Psicanálise: Obras Escolhidas (pp. 254-276). Rio de Janeiro: Imago Ed., 2000.

Winnicott, D. W. (1958g). A Capacidade para Estar Só. In O Ambiente e os Processos de Maturação (pp. 31-37). Porto Alegre: Artmed, 1983.

Winnicott, D. W. (1958j). O Primeiro Ano de Vida. Concepções Modernas do Desenvolvimento Emocional. In A Família e o Desenvolvimento Individual (pp. 3-20). São Paulo: Martins Fontes, 1997.

Winnicott, D. W. (1960c). Teoria do Relacionamento Paterno-Infantil. In O Ambiente e os Processos de Maturação (pp. 38-54). Porto Alegre: Artmed, 1983.

Winnicott, D. W. (1963b). O Desenvolvimento da Capacidade de se Preocupar. In $O$ Ambiente e os Processos de Maturação (pp. 70-78). Porto Alegre: Artmed, 1983.

Winnicott, D. W. (1964h). Resenha de Memories, Dreams, Reflections, de C. G. Jung. In Explorações Psicanalíticas: D. W. Winnicott (pp. 365-372). Porto Alegre: Artes Médicas, 1994.

Winnicott, D. W. (1965r). Da Dependência à Independência no Desenvolvimento do Indivíduo. In O Ambiente e os Processos de Maturação (pp. 79-87). Porto Alegre: Artmed, 1983. 
Winnicott, D. W. (1965va). Enfoque Pessoal da Contribuição Kleiniana. In O Ambiente e os Processos de Maturação (pp. 156-162). Porto Alegre: Artmed, 1983.

Winnicott, D. W. (1965vc). Provisão para a Criança na Saúde e na Crise. In O Ambiente e os Processos de Maturação (pp. 62-69). Porto Alegre: Artmed, 1983.

Winnicott, D. W. (1968d). A Comunicação entre o Bebê e a Mãe e entre a Mãe e o Bebê: Convergências e Divergências. In Os Bebês e suas Mães (pp. 79-92). São Paulo: Martins Fontes, 1994.

Winnicott, D. W. (1968e). Delinquency as a sign of hope. In Home is Where We Start From (pp. 90-100). London: Penguin Books, 1986.

Winnicott, D. W. (1968i). O Brincar: Uma Exposição Teórica. In O Brincar \& a Realidade (pp. 59-77). Rio de Janeiro Imago Ed., 1975.

Winnicott, D. W. (1969b). A Amamentação como Forma de Comunicação. In Os Bebês e Suas Mães (pp. 19-27). São Paulo: Martins Fontes, 1994.

Winnicott, D. W. (1969g). Fisioterapia e Relações Humanas. In Explorações Psicanalíticas: D. W. Winnicott (pp. 427-432). Porto Alegre: Artes Médicas, 1994.

Winnicott, D. W. (1969i). O Uso de um Objeto e o Relacionamento através de Identificações. In Explorações Psicanalíticas: D. W. Winnicott (pp. 171-177). Porto Alegre: Artes Médicas, 1994.

Winnicott, D. W. (1971a). O Brincar \& a Realidade (J. O. d. A. Abreu \& V. Nobre, Trans.). Rio de Janeiro: Imago Ed., 1975.

Winnicott, D. W. (1971f). O Conceito de Indivíduo Saudável. In Tudo Começa em Casa (pp. 3-22). São Paulo: Martins Fontes, 1999.

Winnicott, D. W. (1971g). A Criatividade e suas Origens. In O Brincar \& a Realidade (pp. 95-120). Rio de Janeiro: Imago Ed., 1975.

Winnicott, D. W. (1978). Da pediatria à psicanálise Rio de Janeiro: Francisco Alves.

Winnicott, D. W. (1984i). Tipos de Psicoterapia. In Tudo Começa em Casa (pp. 93-103). São Paulo: Martins Fontes, 1999.

Winnicott, D. W. (1986k). Psicanálise e Ciência: Amigas ou Parentes? In Tudo Começa em Casa (pp. XIII-XVIII). São Paulo: Martins Fontes, 1999.

Winnicott, D. W. (1989a). Explorações Psicanalíticas: D. W. Winnicott (J. O. d. A. Abreu, Trans.). Porto Alegre: Artes Médicas, 1994.

Winnicott, D. W. (1989vk). A Psicologia da Loucura: Uma Contribuição da Psicanálise. In Explorações Psicanalíticas: D. W. Winnicott (pp. 94-101). Porto Alegre: Artes Médicas, 1994. 
Winnicott, D. W. (1989vl). Psiconeurose na Infância. In Explorações Psicanaliticas: D. W. Winnicott (pp. 53-58). Porto Alegre: Artes Médicas, 1994.

Winnicott, D. W. (1990). Natureza Humana. Rio de Janeiro: Imago.

Winnicott, D. W. (1994). Explorações Psicanalíticas. Porto Alegre: Artmed.

Winnicott, D. W. (1996f). Psiquiatria Infantil, Serviço Social e Atendimento Alternativo. In Pensando Sobre Crianças (pp. 235-238). Porto Alegre: Artes Médicas, 1997.

Winnicott, D. W. (1997). A família e o desenvolvimento individual. São Paulo: Martins Fontes.

Worden, J. W. (1998). Terapia do luto: um manual para o profissional de saúde mental. Porto Alegre: Artes Médicas.

Zimmermann, E. B. (2005). O ritual como continente psíquico da transformação. Cadernos Junguianos, 1, 32-38.

Zinkin, L. (1998). Dialogue in the Analytic Setting. London and Philadelhia: Jessica Kingslay Publisher. 